\begin{tabular}{|l|l|}
\hline $\begin{array}{l}\text { 2. To: (Receiving Organization) } \\
\text { Distribution }\end{array}$ & $\begin{array}{l}\text { 3. From: (Originating Organization) } \\
\text { Retrieval Engineering }\end{array}$ \\
\hline $\begin{array}{l}\text { 5. Proj./Prog./Dept./Div.: } \\
\text { RPP/WFD }\end{array}$ & $\begin{array}{l}\text { 6. Design Authority/Design Agent/Cog. Engr.: } \\
\text { Charles Grenard, 376-3550 }\end{array}$ \\
\hline
\end{tabular}

8. Originator Remarks:

Document transmitted for approval and release.

11. Receiver Remarks:

11A. Design Baseline Document? []Yes [X] No

4. Related EDT No.:

N/A

7. Purchase Order No.:

N/A

9. Equip./Component No.:

$\mathrm{N} / \mathrm{A}$

10. System/Bldg./Facility:

Tank Farms

12. Major Assm. Dwg. No.:

$$
\text { N/A }
$$

13. Permit/Permit Application No.:

N/A

14. Required Response Date:

August 17, 2000

\begin{tabular}{|c|c|c|c|c|c|c|c|c|c|c|}
\hline 15. & \multicolumn{6}{|c|}{ DATA TRANSMITTED } & (F) & (G) & (H) & (I) \\
\hline $\begin{array}{l}\text { (A) } \\
\text { Item } \\
\text { No. }\end{array}$ & \multicolumn{2}{|c|}{ (B) Document/Drawing No. } & $\begin{array}{l}\text { (C) } \\
\text { Sheet } \\
\text { No. }\end{array}$ & $\begin{array}{l}\text { (D) } \\
\text { Rev. } \\
\text { No. }\end{array}$ & \multicolumn{2}{|c|}{ (E) Title or Description of Data Transmitted } & $\begin{array}{c}\text { Approval } \\
\text { Designator }\end{array}$ & $\begin{array}{l}\text { Reason } \\
\text { for } \\
\text { Trans- } \\
\text { mittal }\end{array}$ & $\begin{array}{c}\text { Origi- } \\
\text { nator } \\
\text { Dispo- } \\
\text { sition }\end{array}$ & $\begin{array}{l}\text { Receiver } \\
\text { Dispo- } \\
\text { sition }\end{array}$ \\
\hline 1 & \multicolumn{2}{|l|}{ RPP-5643 } & --- & 0 & \multicolumn{2}{|c|}{$\begin{array}{l}\text { Parametric Study to } \\
\text { Characterize Low-Activity } \\
\text { Waste Tank Heat Removal } \\
\text { Alternatives for Phase } 1 \\
\text { Specification Development }\end{array}$} & $S$ & 1,2 & 1 & \\
\hline \multicolumn{11}{|c|}{ KEY } \\
\hline \multicolumn{2}{|c|}{ Approval Designator $(\mathrm{F})$} & \multicolumn{4}{|c|}{ Reason for Transmittal (G) } & \multicolumn{5}{|c|}{ Disposition (H) \& (I) } \\
\hline \multicolumn{2}{|c|}{$\begin{array}{c}\text { E, S, Q, D or N/A } \\
\text { (see WHC-CM-3-5, Sec. 12.7) }\end{array}$} & $\begin{array}{l}\text { 1. Approval } \\
\text { 2. Release } \\
\text { 3. Infornation }\end{array}$ & \multicolumn{3}{|c|}{$\begin{array}{l}\text { 4. Review } \\
\text { 5. Post-Review } \\
\text { 6. Dist. (Receipt Acknow. Required) }\end{array}$} & $\begin{array}{l}\text { 1. Approved } \\
\text { 2. Approved w/comme } \\
\text { 3. Disapproved w/com }\end{array}$ & & \multicolumn{3}{|c|}{$\begin{array}{l}\text { 4. Reviewed no/comment } \\
\text { 5. Reviewed w/comment } \\
\text { 6. Receipt acknowledged }\end{array}$} \\
\hline
\end{tabular}

17.

SIGNATURE/DISTRIBUTION

(See Approval Designator for required signatures)

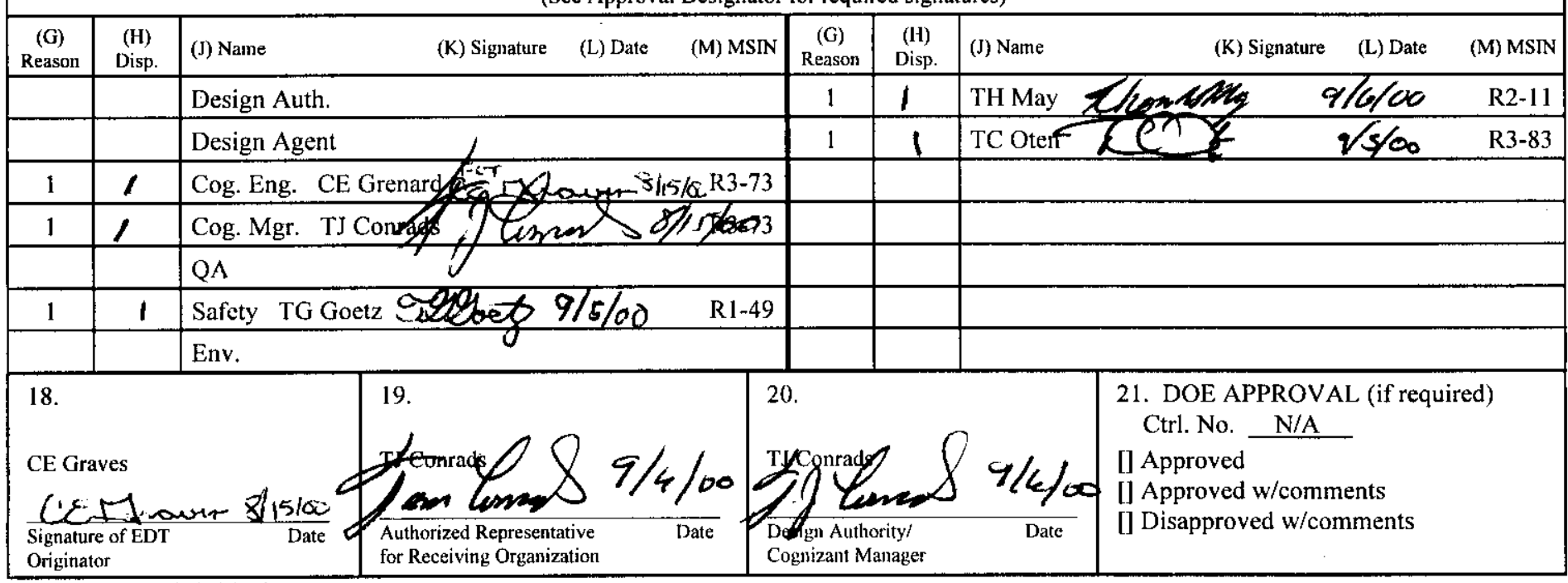

BD-7400-172-2 (10/97) 


\section{DISTRIBUTION SHEET}

\begin{tabular}{|c|c|c|c|c|c|}
\hline \multirow{2}{*}{$\begin{array}{l}\text { To: } \\
\text { Distribution }\end{array}$} & \multirow{2}{*}{\multicolumn{3}{|c|}{$\begin{array}{l}\text { From: } \\
\text { Retrieval Engineering }\end{array}$}} & \multicolumn{2}{|l|}{ Page 1 of 1} \\
\hline & & & & \multicolumn{2}{|c|}{ Date $08 / 17 / 00$} \\
\hline \multirow{2}{*}{\multicolumn{4}{|c|}{$\begin{array}{l}\text { Project Title/Work Order: } \\
\text { RPP-5643, Rev. 0, Parametric Study to Characterize Low-Activity Waste Tank Heat } \\
\text { Removal Alternatives for Phase } 1 \text { Specification Development }\end{array}$}} & \multicolumn{2}{|c|}{ EDT No. 625324} \\
\hline & & & & \multicolumn{2}{|c|}{ ECN No. --- } \\
\hline \multicolumn{2}{|c|}{ Name } & $\begin{array}{l}\text { Text } \\
\text { With All } \\
\text { Attach. }\end{array}$ & $\begin{array}{l}\text { Text } \\
\text { Only }\end{array}$ & $\begin{array}{l}\text { Attach./ } \\
\text { Appendix } \\
\text { Only }\end{array}$ & $\begin{array}{c}\text { EDT/ECN } \\
\text { Only }\end{array}$ \\
\hline
\end{tabular}

WL Adams

AF Choho

TJ Conrads

TG Goetz

CE Grenard

TH May

RL Neavill (Project Files)

TC Oten

$\begin{array}{ll}\text { S6-15 } & \text { X } \\ \text { R3-73 } & \text { X } \\ \text { R3-73 } & \text { X } \\ \text { R1-49 } & \text { X } \\ \text { R3-73 } & \text { X } \\ \text { R2-11 } & \text { X } \\ \text { R3-73 } & \text { X } \\ \text { R3-83 } & \text { X }\end{array}$




\title{
Parametric Study to Characterize Low-Activity Waste Tank Heat Removal Alternatives for Phase 1 Specification Development
}

\author{
Charles E. Grenard \\ Numatec Hanford Corporation \\ Richland, WA 99352 \\ U.S. Department of Energy Contract DE-AC06-99RL-14047 \\ EDT/ECN: 625324 \\ UC: 721 \\ Org Code: $6 \mathrm{~N} 100$ \\ Charge Code: \\ B\&R Code: \\ Total Pages: 134
}

Key Words:

Low-activity waste, heat removal, phase 1, waste feed delivery, specification, parametric, double-shell tank

\section{Abstract:}

Alternative for removing heat from Phase 1, low-activity waste feed double-shell tanks using the ventilation systems have been analyzed for Phase 1 waste feed delivery. The analysis was a parametric study using a model that predicted the waste temperatures for a range of primary and annulus ventilation system flow rates. The analysis was performed to determine the ventilation flow required to prevent the waste temperature from exceeding the Limiting Conditions for Operation limits during normal operation and the Safety Limits during off-normal events.

TRADEMARK DISCLAIMER. Reference herein to any specific commercial product, process, or service by trade name, trademark, manufacturer, or otherwise, does not necessarily constitute or imply its endorsement, recommendation, or favoring by the United States Government or any agency thereof or its contractors or subcontractors.

Printed in the United States of America. To obtain copies of this document, contact: Document Control Services, P.O. Box 950, Mailstop H6-08, Richland WA 99352, Phone (509) 372-2420; Fax (509) 376-4989.
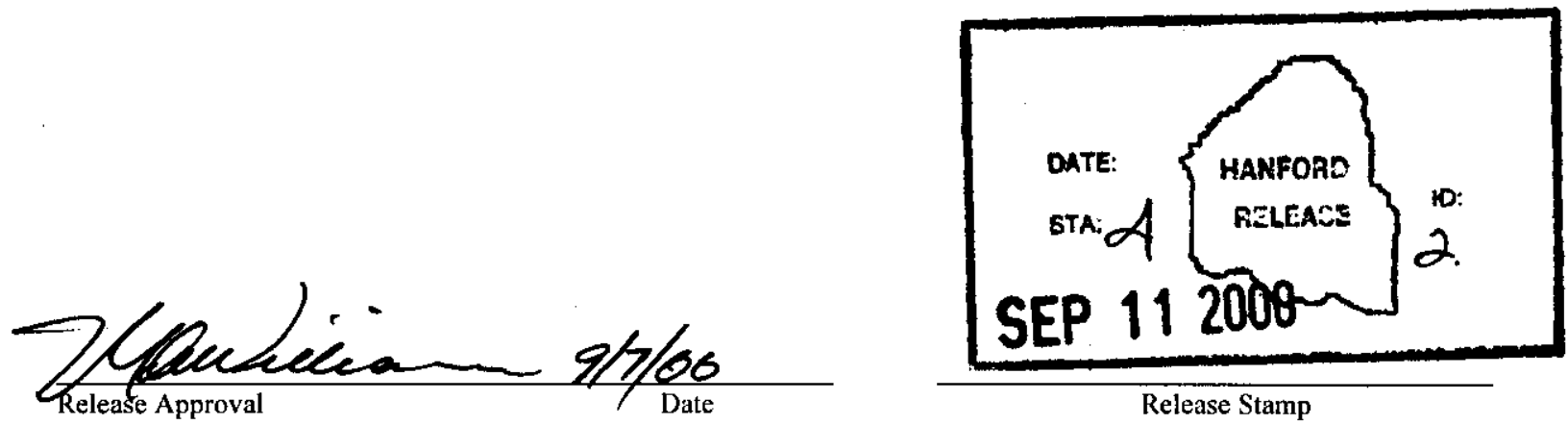
RPP-5643

Revision 0

\section{Parametric Study to Characterize Low-Activity Waste Tank Heat Removal Alternatives for Phase 1 Specification Development}

Prepared for the U.S. Department of Energy Assistant Secretary for Environmental Management

\section{CH2MHILL Hanford Group, Inc.}

Richland, Washington

Contractor for the U.S. Department of Energy

Office of River Protection under Contract DE-AC06-99RL14047 
RPP-5643

Revision 0

\section{Parametric Study to Characterize Low-Activity Waste Tank Heat Removal Alternatives for Phase 1 Specification Development}

C. E. Grenard

Numatec Hanford Corporation

Date Published

August 2000

\section{CH2MHILL}

Hanford Group, Inc.

P. O. Box 1500

Richland, Washington

Contractor for the U.S. Department of Energy

Office of River Protection under Contract DE-AC06-99RL14047

Approved for Public Release; Further Dissemination Unlimited 
LEGAL DISCLAIMER

This report was prepared as an account of work sponsored by an agency of the United States Government. Neither the United States Government nor any agency thereof, nor any of their employees, nor any of their contractors, subcontractors or their employees, makes any warranty, express or implied, or assumes any legal liability or responsibility for the

accuracy, completeness, or any third party's use or the results of such use of any information, apparatus, product, or process disclosed, or represents that its use would not infringe privately owned rights. Reference herein to any specific commercial product, process, or service by trade name, trademark, manufacturer, or otherwise, does not necessarily constitute or imply its endorsement, recommendation, or favoring by the United States Government or any agency thereof or its contractors or subcontractors. The views and opinions of authors expressed herein do not necessarily state or reflect those of the United States Government or any agency thereof.

This report has been reproduced from the best available copy. Available in paper copy and microfiche.

Available electronically at hutp://www.doe.gov/bridge. Available for a

processing fee to the U.S. Department of Energy and its contractors, in paper, from:

U.S. Department of Energy

Office of Scientific and Technical Information

P.O. Box 62

Oak Ridge, TN 37831-0062

phone: $865-576-8401$

fax: 865-576-5728

email: reports@adonis.osti.gov(423) 576-8401

Available for sale to the public, in paper, from:

U.S. Department of Commerce

National Technical Information Service

5285 Port Royal Road

Springfield, VA 22161

Phone: 800-553-6847

fax: 703-605-6900

email: orders@ ntis.fedworld.gov

online ordering:

http://www.ntis.gov/ordering.htm 


\section{CONTENTS}

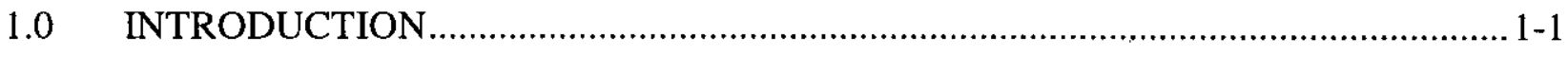

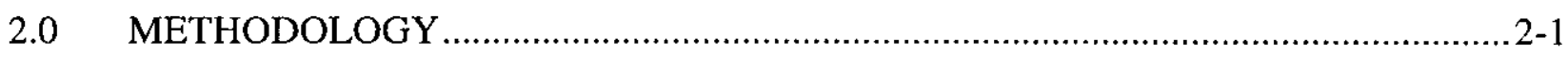

2.1 PARAMETRIC ANALYSES DESCRIPTION .............................................. 2-1

2.1.1 Parametric Study Cases ....................................................................2-1

2.1.2 Parametric Study Analysis Sequence ................................................... 2-1

2.2 TANK SELECTION ................................................................................ 2-3

2.3 PARAMETRIC STUDY INPUT PARAMETERS ........................................2-3

2.3.1 Allocation of Primary and Annulus Flow Rates ....................................2-3

2.3.2 Retrieval Strategies .......................................................................... 2-3

2.3.3 Thermal Parameter of the Decanting and Nondecanting Strategies ........2-4

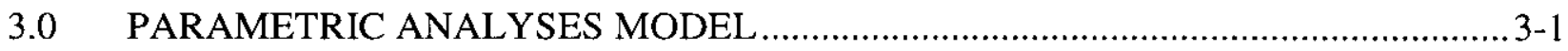

3.1 GOTH_SNF MODEL DEVELOPMENT .................................................

3.2 GOTH_SNF MODÉL GENERAL DESCRIPTION........................................ 3-1

4.0 PARAMETRIC ANALYSES RESULTS .................................................................

4.1 MIXER PUMP OPERATION WITH SUPERNATANT DECANTING............ 4-1

4.1.1 Primary Ventilation Evaluation with Supernatant Decanting ...................4-2

4.1.2 Annulus Ventilation Evaluation with Supernatant Decanting ...............4-10

4.1.3 Waste Resettling with Supernatant Decanting ........................................4-11

4.2 MIXER PUMP OPERATION WITHOUT SUPERNATANT

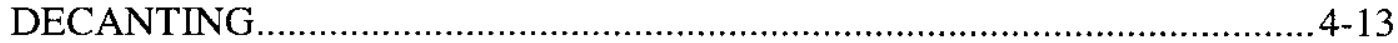

4.2.1 Primary Ventilation Evaluation without Supernatant Decanting ............4-15

4.2.2 Annulus Ventilation Evaluation without Supernatant Decanting ….......4-17

4.2.3 Waste Resettling without Supernatant Decanting ...................................4-17

4.3 PRIMARY VENTILATION MOISTURE CARRYOVER.............................. 4-18

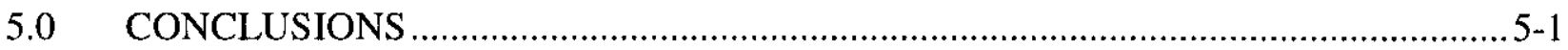

5.1 RETRIEVAL WITH SUPERNATANT DECANTING ……............................. $5-1$

5.2 RETRIEVAL WITHOUT SUPERNATANT DECANTING.............................. 5-1

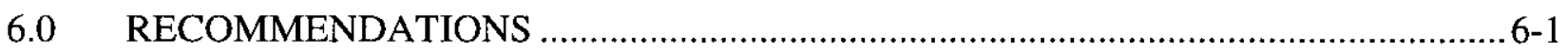

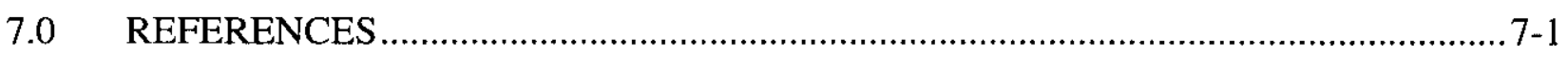




\section{RPP-5643 REV 0}

\section{APPENDICES}

A TANK SELECTION FOR A PARAMETRIC STUDY TO CHARACTERIZE LOW-LEVEL WASTE TANK HEAT REMOVAL ALTERNATIVES FOR PHASE 1 SPECIFICATION DEVELOPMENT

B MEMORANDUM - "INTERIM GUIDANCE ON LAW RETRIEVAL STRATEGY"

C PHYSICAL PROPERTIES OF TANK 241-AN-103 WASTE FOR USE IN HEAT REMOVAL ALTERNATIVES STUDY

D BOUNDARY CONDITIONS - VENTILATION INLET NOMINAL TEMPERATURE AND ABSOLUTE HUMIDITY

\section{FIGURES}

Figure 2-1. Overview of Analyses Sequence. …………...............................................2-2

Figure 3-1. GOTH_SNF Model Schematic......................................................................3-2

Figure 3-2. GOTH_SNF One-Dimensional Noding Scheme. ...............................................3-3

Figure 4-1. Description of GOTH_SNF Plot Parameters. ...................................................4-3

Figure 4-2. GOTH_SNF Model Initialization Analyses.*....................................................4-4

Figure 4-3. Typical Mixed-Waste Temperatures with Decanting (Case D2).........................4-5

Figure 4-4. Maximum Mixed-Waste Temperature with Decanting and 100 Percent Pump Power.

Figure 4-5. Mixed-Waste Temperatures for $0.47 \mathrm{~m}^{3} / \mathrm{s}\left(1,000 \mathrm{ft}^{3} / \mathrm{min}\right)$ Primary Flow Rate.

Figure 4-6. Time to Temperature Limit with Decanting and 100 Percent Pump Power........4-8

Figure 4-7. Maximum Mixed-Waste Temperature for Reduced Mixer Pump Power.

Figure 4-8. Annulus Flow Parametric for Maximum Mixed-Waste Temperature with Decanting and 100 Percent Pump Power.

Figure 4-9. Annulus Flow Parametric for Time to Temperature Limit with Decanting and 100 Percent Pump Power.

Figure 4-10. Resettled Waste Temperatures with Decanting. $4-12$ 


\section{RPP-5643 REV 0}

Figure 4-11. Typical Mixed-Waste Temperatures without Supernatant Decanting. ...............4-15

Figure 4-12. Time to Temperature Limit Without Decanting. .................................................4-16

Figure 4-13. Annulus Ventilation Parametric for Time to Temperature with Decanting and 50 Percent Pump Power.........................................................................4-17

Figure 4-14. Predicted Moisture Carryover for Nominal Ventilation Flow...........................4-19

Figure 4-15. Moisture Carryover for Primary Ventilation Flows...........................................4-20

\section{TABLES}

Table 2-1. Thermal Parameters Common to Both Decanting and the Nondecanting

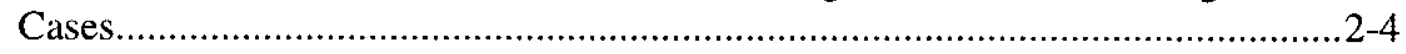

Table 2-2. Thermal Parameters that Differ Between Decanting and Nondecanting

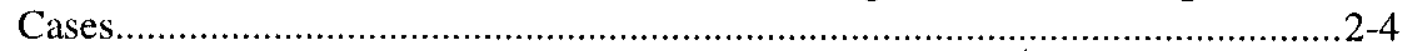

Table 4-1. Summary of Results for Decanted Cases. ............................................................4-2

Table 4-2. Summary of Results for Nondecanted Cases..................................................4-14 


\section{RPP-5643 REV 0}

\section{TERMS}

JMI

LCO

LCS

LAW

TSR
John Marvin, Inc.

Limiting Conditions for Operation

Limiting Control Setting

Low-Activity Waste

Technical Safety Requirement 


\section{RPP-5643 REV 0}

\subsection{INTRODUCTION}

Alternatives for removing heat from Phase 1, low-activity waste (LAW) feed double-shell tanks using the ventilation systems have been analyzed for Phase 1 waste feed delivery. The analysis was a parametric study using a model that predicted the waste temperatures for a range of primary and annulus ventilation system flow rates. The analysis was performed to determine the ventilation flows required to prevent the waste temperature from exceeding the Limiting Conditions for Operation limits during normal operation and the Safety Limits during off-normal events. The limits are specified in HNF-SD-WM-TSR-006, Tank Waste Remediation System Technical Safety Requirement (TSR). The results may change if the temperature limits in the TSR are changed in the future. 
RPP-5643 REV 0

This page intentionally left blank. 


\subsection{METHODOLOGY}

An analytical model was built using the GOTH SNF thermal model. The analysis was based on the following analytical sequence, the bounding retrieval strategies that were analyzed, and the input parameters. Details of the model are discussed in Section 3.0.

\subsection{PARAMETRIC ANALYSES DESCRIPTION}

The analytical sequence and input parameters are discussed in the following sections.

\subsubsection{Parametric Study Cases}

Two system modifications - primary and annulus ventilation system enhancements - were considered for the LAW heat removal parametric analyses. A base case was run using the existing primary and annulus system flow rates. If one or more of the temperature limits were violated, either the primary or annulus ventilation flow rate was increased to determine what flow was required to maintain an acceptable waste temperature. The maximum annulus flow rate was limited to a $0.47 \mathrm{~m}^{3} / \mathrm{s}\left[1,000 \mathrm{ft}^{3} / \mathrm{min}\right.$ (standard) $]$. This is the maximum reasonably achievable flow considering the design of the cooling slots at the bottom of the tank.

\subsubsection{Parametric Study Analysis Sequence}

The LAW parametric analysis was divided into four distinct activities. Theses activities are (1) preretrieval (i.e., normal storage), (2) retrieval (mixer pump operating), (3) post-retrieval (mixer pump operation stopped), and (4) loss of ventilation system. The expected temperature response of the solids during each activity is shown on Figure 2-1. Each activity is discussed in more detail below:

1. Preretrieval (normal operation). First, a thermal analysis was performed to characterize the supernatant and peak solids temperatures during normal tank storage. This analysis initialized the thermal model of the tank waste and surrounding soil before retrieval operations began. Before continuing with the analysis, the predicted waste temperatures must be consistent with actual temperatures. The applicable temperature limit during this portion of the analyses is the Limiting Control Setting (LCS)/Limiting Conditions for Operation (LCO) 3.3.2.b temperature criteria.

2. Retrieval (mixer pump operating). Second, the mixer pumps mix and mobilize the settled sludge during retrieval operations (Region 1). The sludge and supernatant are assumed to be in a fully mixed-waste condition. The instantaneous mixed-waste temperature (i.e., the mixed-waste temperature without any pump heat) is the minimum mixed-waste temperature $\left(\mathrm{T}_{3}\right)$ at the start of retrieval operations. As mixer pumps continue to operate, the mixed-waste temperature approaches steady state, the maximum mixed-waste temperature during retrieval operations. The applicable temperature limit during mixer pump operations is $\leq 90.6^{\circ} \mathrm{C}\left(195^{\circ} \mathrm{F}\right)(\mathrm{LSC} / \mathrm{LCO} 3.3 .2 . \mathrm{a})$. 


\section{RPP-5643 REV 0}

3. Post-Retrieval (mixer pump operation stopped). When mixer pumps operation stops, undissolved waste will begin to resettle, resulting in a fluffed waste layer (i.e., a layer with a smaller particle volume fraction relative to the pre-mixed settled waste). Elevated supernatant temperatures in conjunction with waste resettling could result in elevated settled waste temperatures. The most limiting condition occurs after the mixed-waste temperature reaches steady state. Figure 2-1 shows qualitatively the expected supernatant $\left(\mathrm{T}_{1}{ }^{\prime}\right)$ and settled-waste $\left(\mathrm{T}_{2}{ }^{\prime}\right)$ profiles. The applicable temperature limit for the post-mixed settled waste is LCS/LCO 3.3.2.b.

Figure 2-1. Overview of Analyses Sequence.

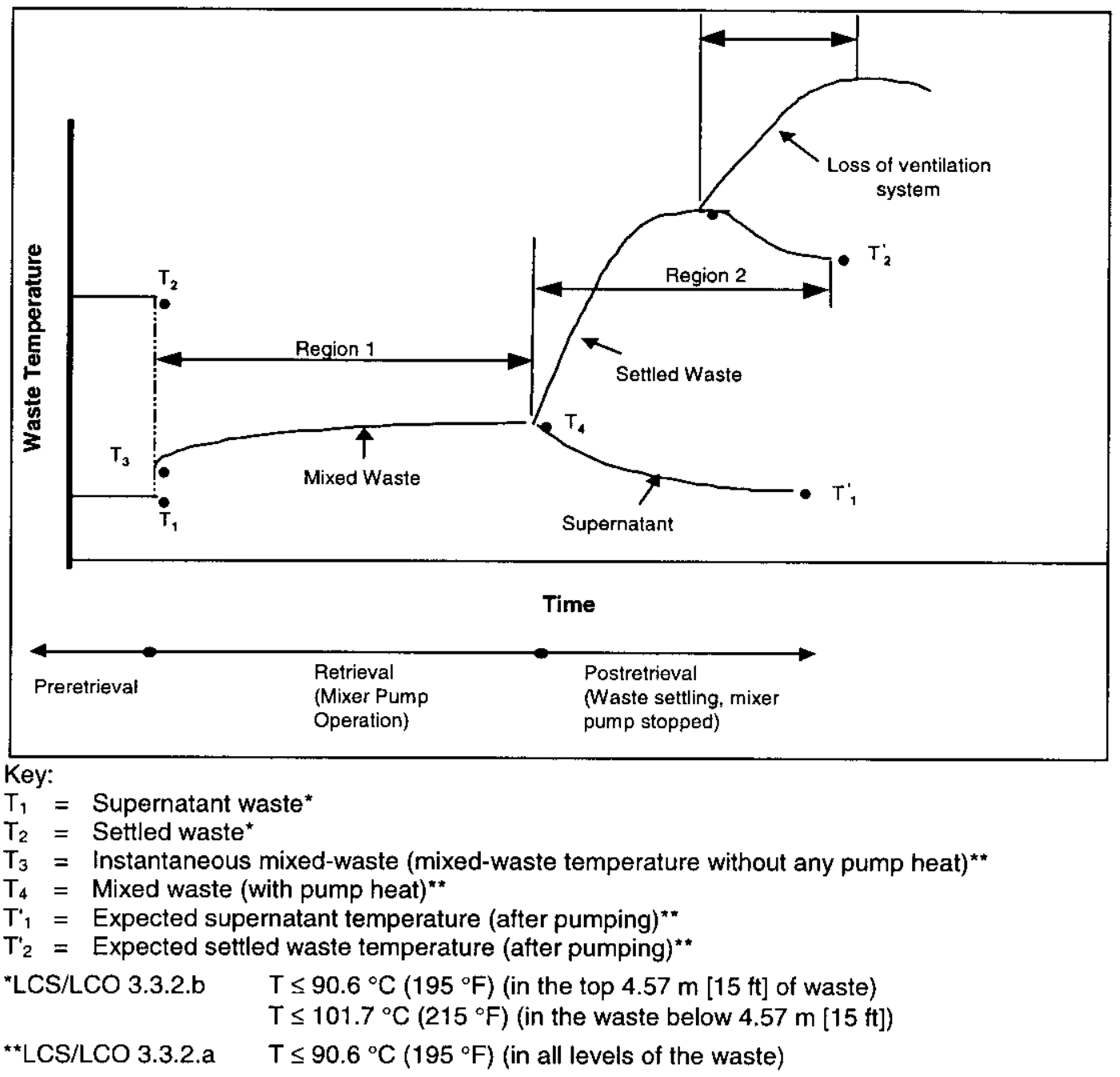

Note: Because double-shell tanks typically operate with a waste level of $9.14 \mathrm{~m}(30 \mathrm{ft})$, both temperature limits for LCS/LCO 3.3.2b apply to the LAW parametric analyses.

4. Loss of Ventilation Flow. A loss of ventilation when the mixed-waste temperature reaches a maximum could result in higher temperatures if the heat load in the settled solids is significant. However, the LAW tanks have very low heat loads resulting in a low heat-up rate (temperature increase as a function of time), which will provide plenty of time to restore lost ventilation before a temperature limit would be reached. Therefore, thermal analyses were not performed for the loss of ventilation analyses. 
RPP-5643 REV 0

\subsection{TANK SELECTION}

One tank, 241-AN-103, was selected as a bounding case for this analysis based on the combination of radioactive decay heat rate and sludge depth in all the LAW feed source tanks to be retrieved during Phase 1 waste feed delivery. The basis for selecting this tank is provided in Appendix A.

\subsection{PARAMETRIC STUDY INPUT PARAMETERS}

This section discusses summarizes the input parameters used for the study.

\subsubsection{Allocation of Primary and Annulus Flow Rates}

The following sections provide the bases for the range of ventilation flow rates used in this analysis.

2.3.1.1 Primary Ventilation System Flow Rates. The seven tanks in the AN-Tank Farm are served by a common primary ventilation system. The maximum flow capability of this system is on the order of $0.47 \mathrm{~m}^{3} / \mathrm{s}\left(1,000 \mathrm{ft}^{3} / \mathrm{min}\right)$ with a normal flow of $0.04 \mathrm{~m}^{3} / \mathrm{s}\left(85.7 \mathrm{ft}^{3} / \mathrm{min}\right)$ allocated to tank 241-AN-103. A flow rate of up to $0.094 \mathrm{~m}^{3} / \mathrm{s}\left(200 \mathrm{ft}^{3} / \mathrm{min}\right)$ to tank $241-\mathrm{AN}-103$ is achievable with the current system. This will be considered the minimum achievable flow rate for this analysis. A flow rate in excess of $0.47 \mathrm{~m}^{3} / \mathrm{s}\left(1,000 \mathrm{ft}^{3} / \mathrm{min}\right)$ is not considered reasonable. Once-through flow rates of $0.094 \mathrm{~m}^{3} / \mathrm{s}$ [200 $\left.\mathrm{ft}^{3} / \mathrm{min}\right], 0.24 \mathrm{~m}^{3} / \mathrm{s}\left(500 \mathrm{ft}^{3} / \mathrm{min}\right)$, and $0.47 \mathrm{~m}^{3} / \mathrm{s}$ $\left(1,000 \mathrm{ft}^{3} / \mathrm{min}\right)$ will be used for these analyses. Chilling of the inlet air will not be considered in this analysis.

2.3.1.2 Annulus Ventilation System Flow Rate. The seven tanks in the AN-Tank Farm are served by a common annulus ventilation system. The current maximum annulus flow rate to tank 241 -AN-103 is $0.38 \mathrm{~m}^{3} / \mathrm{s}\left(800 \mathrm{ft}^{3} / \mathrm{min}\right)$. Operational experience with this system, however, indicates that a flow rate of up to $0.47 \mathrm{~m}^{3} / \mathrm{s}\left(1,000 \mathrm{ft}^{3} / \mathrm{min}\right)$ for Tank $241-\mathrm{AY}-102$ may be possible with some configuration changes. It is not certain if annulus flow is required to maintain acceptable temperatures. Therefore, once-through flow rates of $0 \mathrm{~m}^{3} / \mathrm{s}\left[0 \mathrm{ft}^{3} / \mathrm{min}\right]$ and $0.094 \mathrm{~m}^{3} / \mathrm{s}$ [200 $\left.\mathrm{ft}^{3} / \mathrm{min}\right]$ will be used for the initial analyses. Flow may be increased up to $0.47 \mathrm{~m}^{3} / \mathrm{s}\left(1,000 \mathrm{ft}^{3} / \mathrm{min}\right)$, if necessary.

\subsubsection{Retrieval Strategies}

The model will be run to analyze two bounding retrieval strategies. For both, the total radioactive decay heat load will be conservatively assumed to remain in the solids.

2.3.2.1 Decanting. The "decanting" retrieval strategy removes the supernatant liquid without disturbing the underlying waste. Decanting is followed by backfilling the tank with water to the

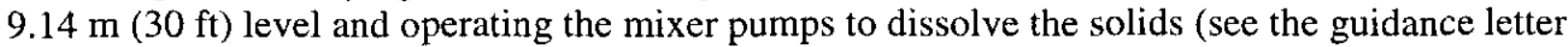
in Appendix B). The remaining insoluble solids depth will be much less than the initial depth. 


\section{RPP-5643 REV 0}

This case results in the lowest vapor suppression (see Section 2.3.4.2) and minimizes the required ventilation flow rates. This case is consistent with the current retrieval plans.

2.3.2.2 Nondecanting. The "nondecanting" retrieval strategy mixes all the waste currently in the tank and allows the solids to settle. This case maximizes the amount of waste dissolved in the supernatant, which leads to highest vapor suppression (see Section 2.3.4.2), and maximizes the depth of the settled solids after termination of mixer pump operation. This case maximizes the ventilation flow rates. This case is consistent with the retrieval strategy at the beginning of this fiscal year.

\subsubsection{Thermal Parameter of the Decanting and Nondecanting Strategies}

The thermal input parameters are shown in Tables 2-1 and 2-2. Table 2-1 shows parameters that are common to both the decanting and the nondecanting strategies. Table 2-2 lists the parameters that are not the same for both strategies. The bases for these numbers are provided in Appendix C.

Table 2-1. Thermal Parameters Common to Both Decanting and the Nondecanting Cases.

\begin{tabular}{|l|c|}
\hline \multicolumn{1}{|c|}{ Thermal Parameter } & Tank 241-AN-103 Parameter Value \\
\hline Solids Density & $3000 \mathrm{~kg} / \mathrm{m}^{3}\left(187.2 \mathrm{lbm} / \mathrm{ft}^{3}\right)$ \\
\hline Liquid Heat Capacity & $3200 \mathrm{~J} / \mathrm{kg}-{ }^{-} \mathrm{C}\left(0.7643 \mathrm{Btu} / \mathrm{bm}-{ }^{\circ} \mathrm{R}\right)$ \\
\hline Solids Heat Capacity & $837 \mathrm{~J} / \mathrm{kg}-{ }^{\circ} \mathrm{C}\left(0.20 \mathrm{Btu} / \mathrm{lbm}-{ }^{\circ} \mathrm{R}\right)$ \\
\hline Thermal Conductivity of Aqueous Solution & $90 \%$ of the value of water \\
\hline Thermal Conductivity of Solids & $8.65 \mathrm{~W} / \mathrm{m}-{ }^{\circ} \mathrm{C}\left(5.0 \mathrm{Btu} / \mathrm{h}-\mathrm{ft}-{ }^{\circ} \mathrm{R}\right)$ \\
\hline Radiolytic Heat & $10.6 \mathrm{~kW}(36,300 \mathrm{Btu} / \mathrm{h})$ \\
\hline
\end{tabular}

Table 2-2. Thermal Parameters that Differ Between Decanting and Nondecanting Cases

\begin{tabular}{|l|c|c|}
\hline \multicolumn{1}{|c|}{ Thermal Parameter } & Decanted Parameter Value & Nondecanted Parameter \\
\hline Fluffed Sludge Height & $0.445 \mathrm{~m}(1.46 \mathrm{ft})$ & $7.19 \mathrm{~m}(23.6 \mathrm{ft})$ \\
\hline $\begin{array}{l}\text { Supernatant Liquid Vapor } \\
\text { Pressure }\end{array}$ & $60 \%$ of the value of water & $31 \%$ of the value of water \\
\hline
\end{tabular}




\subsection{PARAMETRIC ANALYSES MODEL}

This section describes the GOTH_SNF thermal model used for this parametric study. Development of the model is documented in JMI-9911-01. The GOTH_SNF model was benchmarked with measured data for tank 241-AY-102 (RPP-5637).

\subsection{GOTH_SNF MODEL DEVELOPMENT}

GOTH_SNF is a general-purpose, thermal-hydraulics computer program developed by John Marvin, Inc. (JMI). The current version and the predecessor program GOTH have been used extensively at the Hanford Site and other U.S. Department of Energy sites and in the commercial nuclear industry for design, safety, and operations analyses (JMI-980306-2 and JMI-980306-3). GOTH_SNF has been verified and validated and is controlled through the JMI Quality Assurance Program (JMI-980306-1).

\subsection{GOTH_SNF MODEL GENERAL DESCRIPTION}

The GOTH_SNF model incorporates distributed- and lumped-parameter volumes, heat conductors, and flow and pressure boundary conditions to provide a one-dimensional model of tank 241-AN-103 as shown in Figure 3-1.

1. Distributed- and Lumped-Parameter Volumes. The volume inside the tank inner liner is modeled as GOTH_SNF Volume 1s. (Volume is is a distributed-parameter volume with a one-dimensional model of the waste, supernatant, and dome space. The noding scheme for this volume is shown in Figure 3-2.) GOTH_SNF control volume 2 (Figure 3-1) corresponds to the flow volume of the annulus system on the floor of the tank. The flow volume in the annulus ventilation system, between the steel inner liner and outer liner, is modeled with control volume 3 . Control volume 5 models the inlet annulus piping. This includes the drop-legs in the wall annulus region and the horizontal runs of piping leading to the center of the tank. Control volume 4 and valve $1 \mathrm{~V}$ provide make-up water to maintain the supernatant pool level at a near constant value. These modeling devices provide water to maintain a constant pool level and do not represent actual physical components.

2. Heat Conductors. The GOTH_SNF model treats the tank waste and supernatant as fluid volumes with conduction heat transfer within the waste, when the mixer pumps are not operating. Heat transfer from the supernatant surface includes evaporation and convection. Other thermal masses associated with the waste tanks are modeled with one-dimensional heat conductors. The soil directly above the tank is modeled with a one-dimensional wall conductor (Figure 3-1, heat conductor 6. The thickness of this conductor corresponds to the average soil depth above the tank. This conductor uses the ambient temperatures for the top surface and calculated dome temperatures for the bottom surface. 
The soil below the tank is modeled with a one-dimensional wall conductor (heat conductor 4). The thickness of this conductor corresponds to the approximate distance to the water table below the tanks. A constant $12{ }^{\circ} \mathrm{C}\left(54^{\circ} \mathrm{F}\right)$ temperature is used for the surface of the heat conductor. This is the average annual ambient temperature and, therefore, the soil temperature at a distance removed from the tanks.

The soil surrounding the tank side is modeled with tube heat conductor 5. The inside of the tube is connected to the wall annulus (volume 3). The thickness of the tube conductor corresponds to the mid-point between the modeled tank and the surrounding tanks. The heat conductor boundary is assumed adiabatic for the outside surface of the tube conductor.

The steel plates of the inner liner are modeled with three conductors: heat conductor 1 corresponds with the bottom plate; heat conductors 2 and 3 model the side wall liner.

Figure 3-1. GOTH_SNF Model Schematic.

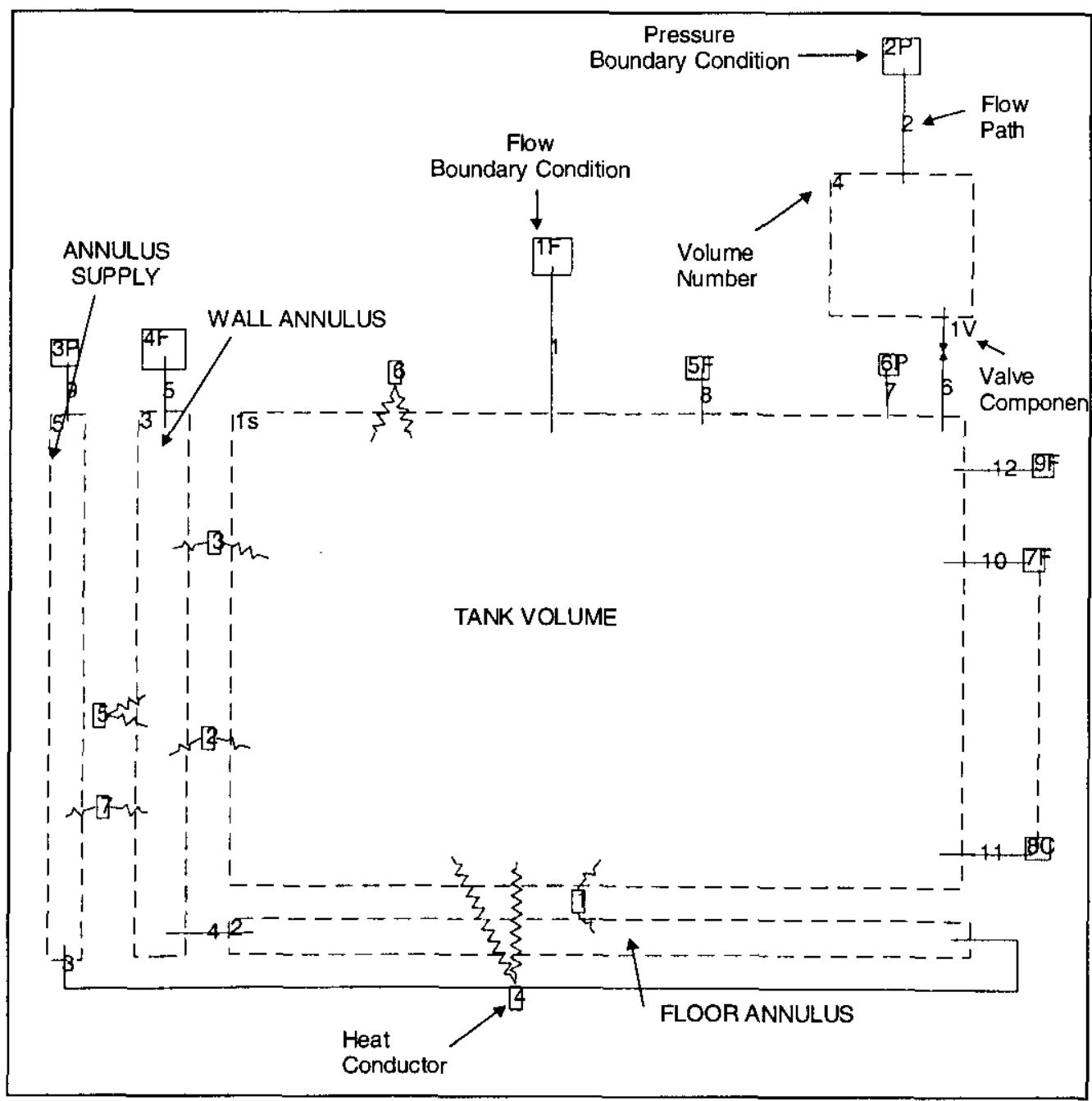


RPP-5643 REV 0

Figure 3-2. GOTH_SNF One-Dimensional Noding Scheme.

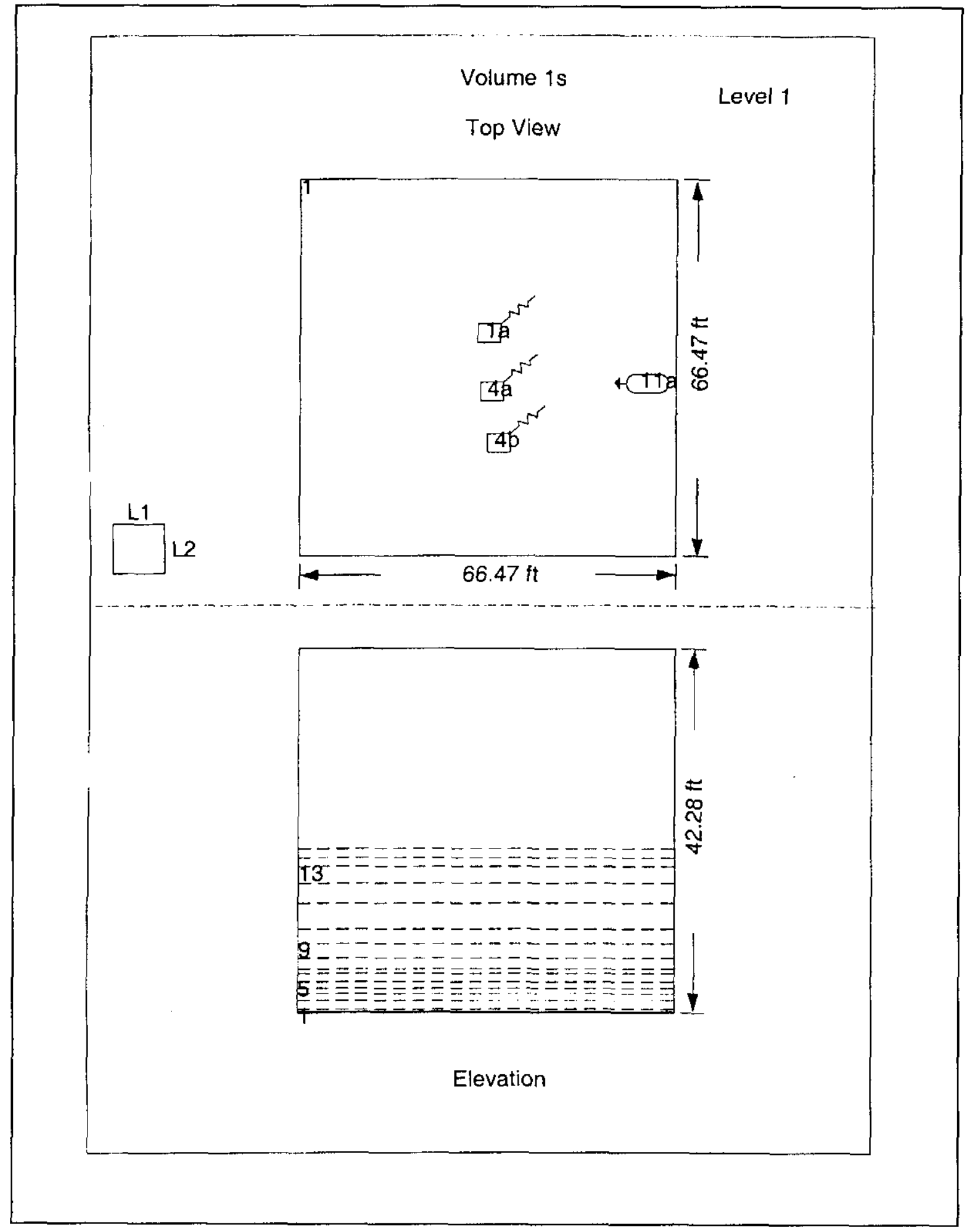


3. Flow and Pressure Boundary Conditions. The primary and annulus flow conditions are modeled with flow boundary conditions 4F and 5F (Figure 3-1). The ventilation flow rates are specified by these boundary conditions.

Flow boundary condition 9F (Figure 3-1) is used to model the mixer pump flow. Pumps draw liquid from the supernatant pool and inject the liquid into the bottom level of waste, mixing the settled waste. The heat associated with the operation of the pumps is modeled with a GOTH_SNF heater component, which inputs a specified amount of heat to the supernatant. The heater component is located near the middle of the supernatant pool.

The GOTH_SNF model uses a boundary condition component to establish the temperature, humidity, and ventilation flow rates for the primary and annulus ventilation systems. Boundary conditions $3 \mathrm{P}$ and $6 \mathrm{P}$ (Figure 3-1) define the monthly average ambient temperature and monthly maximum humidity conditions. Derivation of the monthly average temperature and humidity values used for this analyses are described in Appendix D. 
RPP-5643 REV 0

\subsection{PARAMETRIC ANALYSES RESULTS}

Retrieval operations for LAW tanks (the double-shell tanks except the aging waste tanks 241-AY-101, 241-AY-102, 241-AZ-101, and 241-AZ-102) were analyzed using the GOTH_SNF code and tank $241-\mathrm{AN}-103$ as the bounding case. Predicted supernatant and slurry temperatures were compared with temperature criteria to evaluate the need for primary or annulus ventilation system upgrades. If temperature limits were exceeded for the nominal ventilation configurations, parametric analyses were performed to determine the required ventilation system performance. The results of the parametric evaluations for tank $241-\mathrm{AN}-103$ are provided in the following sections.

\subsection{MIXER PUMP OPERATION WITH SUPERNATANT DECANTING}

The primary and annulus ventilation systems were evaluated for the planned LAW retrieval decanting strategy. The decanting of the supernatant and subsequent mixing of the waste, leads to the maximum dilution of waste. This minimizes the settled solids level after pump operation and reduces the vapor suppression of the supernatant. Parametric analyses were performed for both the primary and annulus ventilation systems. The results of 19 thermal analyses are summarized in Table 4-1. The parametric analyses included mixer pump power (50 percent and 100 percent of full, continuous power), primary ventilation flow, and annulus ventilation flow $\left[0.094,0.24,0.38,0.47 \mathrm{~m}^{3} / \mathrm{s}\left(0,200,500,800,1,000 \mathrm{ft}^{3} / \mathrm{min}\right)\right]$. The primary ventilation evaluation with supernatant decanting is presented in Section 4.1.1, and the annulus ventilation system evaluation with supernatant decanting is presented in Section 4.1.2.

Table 4-1 summarizes the predicted maximum, mixed-waste temperature and the time required to reach the temperature limit during mixer pump operation for decanted cases. The applicable temperature limit during this period of retrieval operations is $91{ }^{\circ} \mathrm{C}\left(195{ }^{\circ} \mathrm{F}\right)$. Operating at 100 percent power with continuous pump operation and primary ventilation flow below $0.47 \mathrm{~m}^{3} / \mathrm{s}\left(1,000 \mathrm{ft}^{3} / \mathrm{min}\right.$ ) (Cases D1 through D7), the predicted mixed-waste temperatures exceed the temperature limit. For low primary ventilation flow rates, mixer pump operation must be terminated when the mixed-waste temperature reaches the temperature limit. The table shows that the predicted mixed-waste temperatures do not exceed the temperature limit for a primary ventilation flow of $0.47 \mathrm{~m}^{3} / \mathrm{s}\left(1,000 \mathrm{ft}^{3} / \mathrm{min}\right)$ or for reduced mixer pump power ( 50 percent of full power). The table also shows that the moisture carryover of the primary ventilation system (mass of moisture carried with the primary ventilation flow) can exceed 0.126 $\mathrm{kg} / \mathrm{s}(1,000 \mathrm{lb} / \mathrm{h})$ for a primary ventilation flow of $0.47 \mathrm{~m}^{3} / \mathrm{s}\left(1,000 \mathrm{ft}^{3} / \mathrm{min}\right)$. The moisture carryover is a strong function of primary ventilation flow.

The results of the predicted settled waste temperatures also are shown in Table 4-1. This is the maximum settled waste temperature after the termination of the mixer pump operation. The resettled waste temperatures are below the temperature limit of $102{ }^{\circ} \mathrm{C}\left(215^{\circ} \mathrm{F}\right)$ for the parametric cases. A large fraction of the initial settled waste is dissolved during the decanting strategy, which minimizes the resettled waste depth. 
Table 4-1. Summary of Results for Decanted Cases.

\begin{tabular}{|c|c|c|c|c|c|c|c|}
\hline \multirow{2}{*}{$\begin{array}{l}\text { Pump } \\
\text { Power }\end{array}$} & \multirow{2}{*}{$\begin{array}{c}\text { Primary } \\
\text { Ventilation } \\
\text { F/ow } \\
\mathrm{m}^{3} / \mathrm{s} \\
\left(\mathrm{ft}^{3} / \mathrm{min}\right)\end{array}$} & \multirow{2}{*}{$\begin{array}{l}\text { Aniulus } \\
\text { Ventilation } \\
\text { Flow } \\
\text { m/s } \\
\text { (ft/min) }\end{array}$} & \multirow{2}{*}{$\begin{array}{l}\text { Parametric } \\
\text { Case } \\
\text { Identifi } \\
\text { catlon } \\
\text { Number. }\end{array}$} & \multicolumn{3}{|c|}{ Mixer Pamp Operation } & \multirow{2}{*}{$\begin{array}{l}\text { Post Mixer } \\
\text { Pump } \\
\text { Operation } \\
\text { Settled Waste } \\
\text { Temperature } \\
\text { oC (OF) }\end{array}$} \\
\hline & & & & $\begin{array}{l}\text { Mixed-Waste } \\
\text { Temperature } \\
{ }^{\circ} \mathrm{C}\left({ }^{\circ} \mathrm{F}\right)\end{array}$ & $\begin{array}{l}\text { Time to Reach } \\
\text { Temperature } \\
\text { Linut (Days) }\end{array}$ & $\begin{array}{l}\text { Molsture } \\
\text { Carryover } \\
\text { kg/s (1bornh) }\end{array}$ & \\
\hline \multirow{11}{*}{$100 \%$} & $0.04(85.7)$ & $0.38(800)$ & D1 & $116(240)$ & 27 & $0.02(162)$ & $54(130)$ \\
\hline & $0.094(200)$ & $0.38(800)$ & $\mathrm{D} 2$ & $106(222)$ & 30 & $.0436(346)$ & $47(116)$ \\
\hline & \multirow{5}{*}{$0.24(500)$} & 0 & D3 & $97(206)$ & 34 & $0.0989(785)$ & $44(112)$ \\
\hline & & $0.094(200)$ & D4 & $96(204)$ & 35 & $0.0984(781)$ & $42(108)$ \\
\hline & & $0.24(500)$ & D5 & $95(202)$ & 36 & $0.0975(774$ & $40(104)$ \\
\hline & & $0.38(800)$ & D6 & $94(202)$ & 37 & $0.961(763)$ & $39(102)$ \\
\hline & & $0.47(1,000)$ & D7 & $93(200)$ & 37 & $0.948(752)$ & $38(100)$ \\
\hline & \multirow{4}{*}{$0.47(1,000)$} & 0 & D8 & $88(190)$ & NA & $0.142(1130)$ & $38(100)$ \\
\hline & & $0.094(200)$ & D9 & $87(188)$ & NA & $0.137(1090)$ & $36(97)$ \\
\hline & & $0.24(500)$ & D 10 & $87(188)$ & $\mathrm{NA}$ & $0.136(1080)$ & $35(95)$ \\
\hline & & $0.38(800)$ & D11 & $86(187)$ & NA & $0.132(1050)$ & $34(94)$ \\
\hline \multirow{8}{*}{$50 \%$} & $0.04(85.7)$ & $0.38(800)$ & $\mathrm{D} 12$ & $81(177)$ & NA & $0.0113(90)$ & $52(125)$ \\
\hline & $0.094(200)$ & $0.38(800)$ & D13 & $77(170)$ & $\mathrm{NA}$ & $0.019(151)$ & $44(1,12)$ \\
\hline & \multirow{5}{*}{$0.24(500)$} & 0 & D14 & $73(163)$ & NA & $0.0354(281)$ & $44(111)$ \\
\hline & & $0.094(200)$ & D 15 & $72(162)$ & NA & $0.0335(266)$ & $42(107)$ \\
\hline & & $0.24(500)$ & D16 & $71(159)$ & NA & $0.0312(248)$ & $39(102)$ \\
\hline & & $0.38(800)$ & D17 & $69(157)$ & NA & $0.03(238)$ & $38(100)$ \\
\hline & & $0.47(1,000)$ & D18 & $69(156)$ & NA & $0.029(230)$ & $37(98)$ \\
\hline & $0.47(1,000)$ & $0.38(800)$ & D19 & $63(146)$ & NA & $0.0386(306)$ & $34(93)$ \\
\hline
\end{tabular}

\subsubsection{Primary Ventilation Evaluation with Supernatant Decanting}

The primary ventilation system was evaluated by performing thermal analyses for the expected retrieval operations. This evaluation included primary ventilation flows of $85.7,200,500$, and $0.47 \mathrm{~m}^{3} / \mathrm{s}\left(0.04,0.094,0.24\right.$, and $\left.1,000 \mathrm{ft}^{3} / \mathrm{min}\right)$. A flow of $0.94 \mathrm{~m}^{3} / \mathrm{s}\left(200 \mathrm{ft}^{3} / \mathrm{min}\right)$ is identified as the nominal ventilation flow for the bounding tank $241-\mathrm{AN}-103$.

Figure 4-1 is a schematic of a double-shell tank that shows the non-convective slurry layer, the convective liquid (supernatant), and selected GOTH_SNF code parameters. The GOTH_SNF 


\section{RPP-5643 REV 0}

parameters are identified on the GOTH_SNF graphics shown in the following sections and in Figure 4-1 for clarification. A typical parameter is TLs3. The " $T$ " denotes a temperature parameter, "L" denotes the liquid phase, and "s16" refers to the third cell in tank volume, which is in the settled solid layer. This is the waste temperature at this axial location, when the liquid and waste particles are in thermal equilibrium. The figure also shows the location of parameter TVs16. The "V" denotes vapor. This parameter is the vapor temperature in the dome space. Some labeling will also be provided on the GOTH_SNF graphs for additional clarity.

Figure 4-1. Description of GOTH_SNF Plot Parameters.

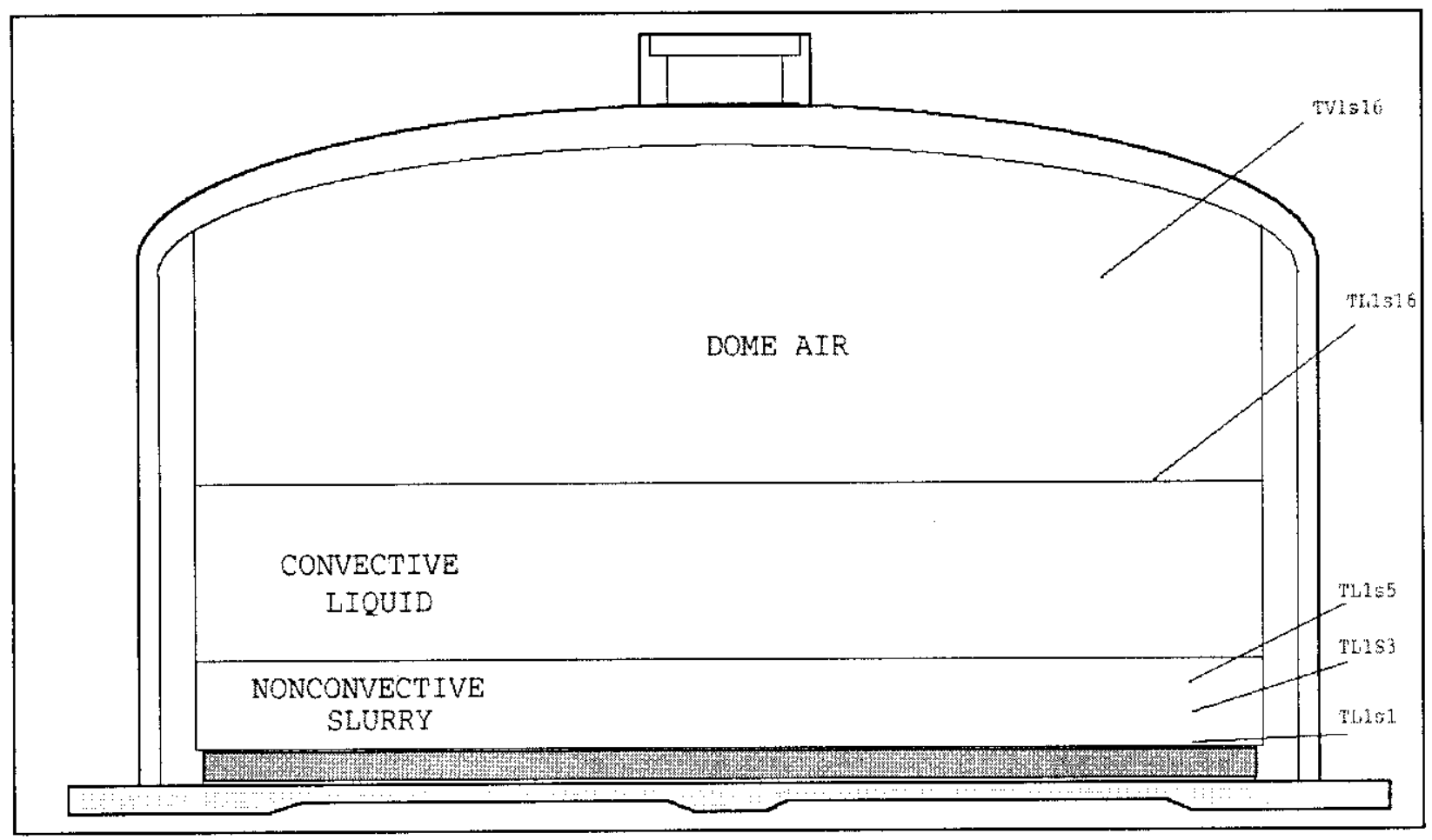




\section{RPP-5643 REV 0}

The primary ventilation system parametric analyses were performed with an annulus ventilation flow of $0.38 \mathrm{~m}^{3} / \mathrm{s}\left(800 \mathrm{ft}^{3} / \mathrm{min}\right)$, which is identified as the nominal ventilation flow for tank 241-AN-102 (Appendix A). Four parametric analyses for 100 percent mixer pump power are shown in Table 4-1 as cases D1, D2, D6 and D11. More than a year of preretrieval normal tank operation was simulated to initialize the model to annual ambient meteorological conditions (Figure 4-2). The ambient conditions used for this analysis are described in Appendix D.

Figure 4-2. GOTH_SNF Model Initialization Analyses.*

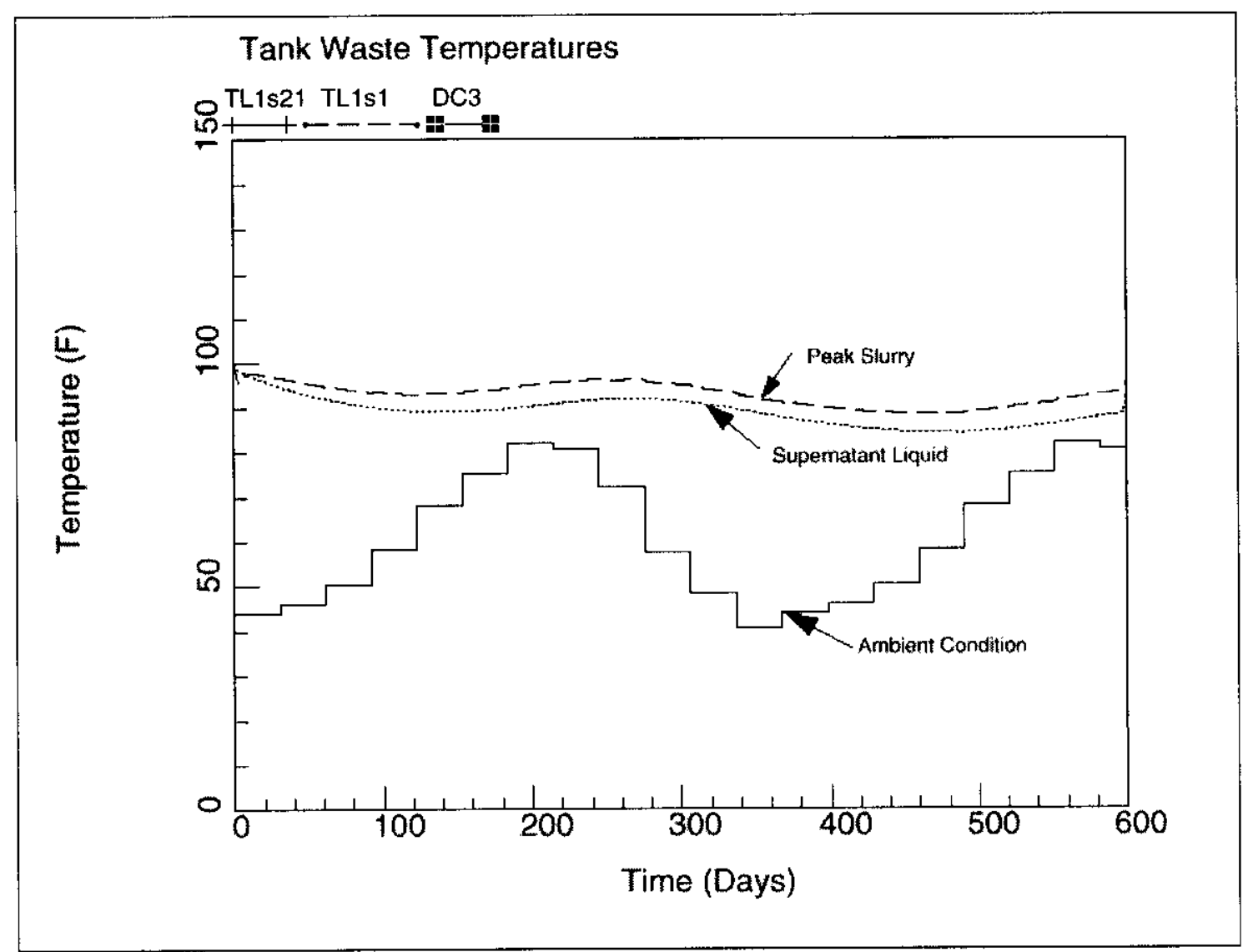

To convert ${ }^{\circ} \mathrm{F}$ to ${ }^{\circ} \mathrm{C}, t^{\circ} \mathrm{C}=\left(t_{\circ} \mathrm{F}-32\right) / 1.8$.

*Monthly average ambient temperature. 


\section{RPP-5643 REV 0}

In the model, mixer pump operation was initiated approximately 30 days before peak summer temperatures to maximize the mixed-waste temperature near the peak summer temperature. The predicted mixed-waste temperatures for case D2 $\left[0.94 \mathrm{~m}^{3} / \mathrm{s}\left(200 \mathrm{ft}^{3} / \mathrm{min}\right)\right.$ primary and $0.38 \mathrm{~m}^{3} / \mathrm{s}$ $\left(800 \mathrm{ft}^{3} / \mathrm{min}\right)$ annulus] are shown in Figure 4-3. The dome and supernatant temperatures are labeled on the figure. The remaining three curves show representative settled waste temperatures after the mixer pump operation is stopped and the waste is allowed to settle. The time axis of Figure 4-3 indicates the days from the beginning of the simulation. The mixer pump operation was initiated at 595 days (from the beginning of the simulation). The mixed-waste temperature increases nearly linearly. The mixed-waste temperature limit of $91^{\circ} \mathrm{C}\left(195^{\circ} \mathrm{F}\right)$ is exceeded at 625 days which is 30 days after the initiation of the mixer pumps. This simulation assumes the mixer pumps operate continuously at full power.

Figure 4-3. Typical Mixed-Waste Temperatures with Decanting (Case D2).

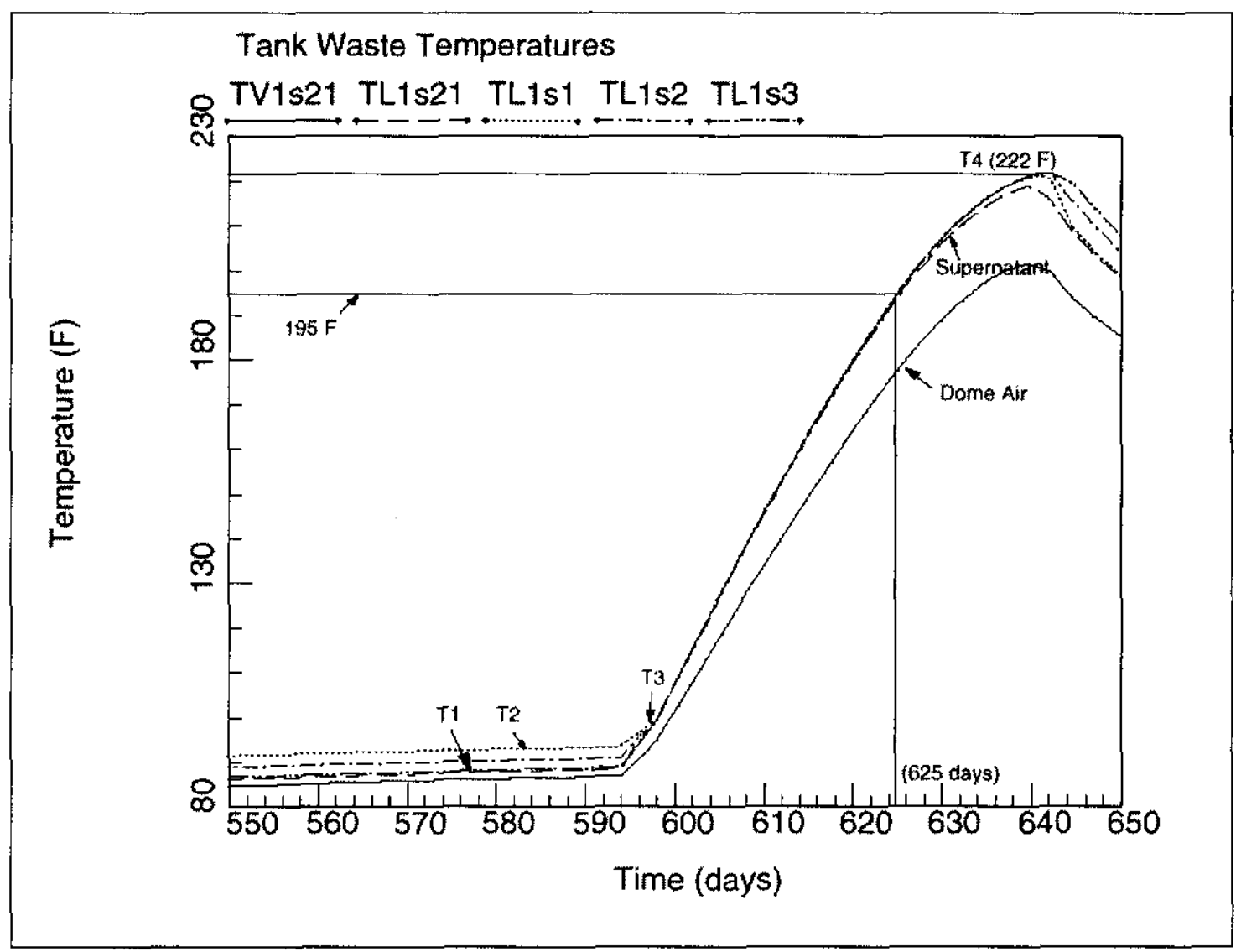

To convert ${ }^{\circ} \mathrm{F}$ to ${ }^{\circ} \mathrm{C}, t^{\circ} \mathrm{C}=\left(t^{\circ} \mathrm{F}-32\right) / 1.8$. 


\section{RPP-5643 REV 0}

The predicted maximum mixed-waste temperature for primary ventilation flow rates ranging from $0.04 \mathrm{~m}^{3} / \mathrm{s}\left(85.7 \mathrm{ft}^{3} / \mathrm{min}\right)$ to $0.47 \mathrm{~m}^{3} / \mathrm{s}\left(1,000 \mathrm{ft}^{3} / \mathrm{min}\right)$ are shown in Figure $4-4$. The annulus system flow rate was constant at the nominal value of $0.38 \mathrm{~m}^{3} / \mathrm{s}\left(800 \mathrm{ft}^{3} / \mathrm{min}\right)$. These simulations were performed for continuous, full-power mixer pump operation. These parametric analyses for primary ventilation flow rate show that the mixed-waste temperature limit is exceeded for primary system flow rate of $0.24 \mathrm{~m}^{3} / \mathrm{s}\left(500 \mathrm{ft}^{3} / \mathrm{min}\right)$ or less. The maximum mixed-waste temperature is below the temperature limit for a primary flow rate of $0.47 \mathrm{~m}^{3} / \mathrm{s}\left(1,000 \mathrm{ft}^{3} / \mathrm{min}\right)$. The mixed-waste temperature is just at the temperature limit for a primary ventilation flow rate between $0.33 \mathrm{~m}^{3} / \mathrm{s}\left(700 \mathrm{ft}^{3} / \mathrm{min}\right)$ and $0.38 \mathrm{~m}^{3} / \mathrm{s}\left(800 \mathrm{ft}^{3} / \mathrm{min}\right)$.

Figure 4-4. Maximum Mixed-Waste Temperature with Decanting and 100 Percent Pump Power.

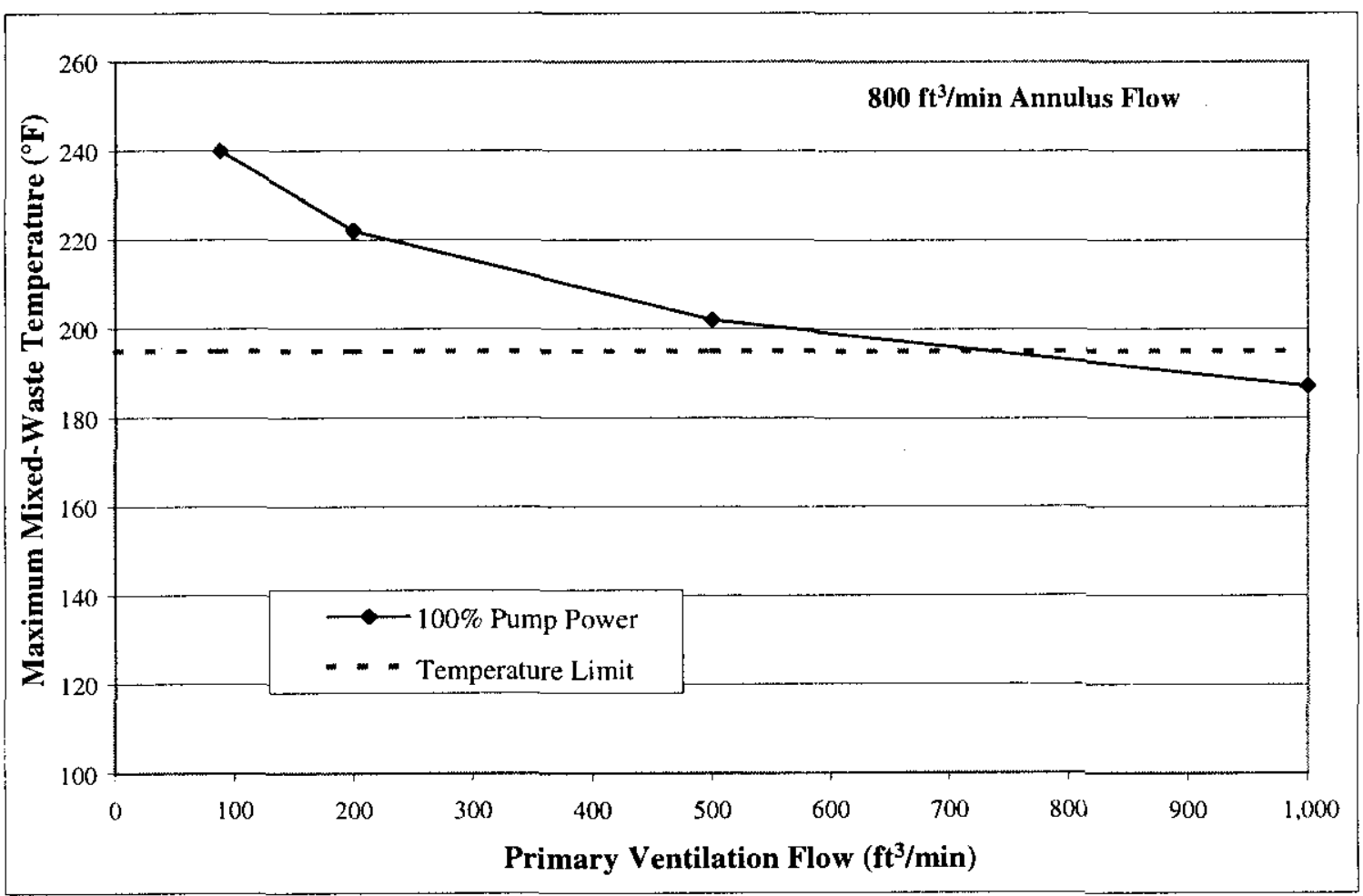

To convert ${ }^{\circ} \mathrm{F}$ to ${ }^{\circ} \mathrm{C}, t_{{ }^{\circ} \mathrm{C}}=\left(t_{\mathrm{oF}}-32\right) / 1.8$. 
The GOTH_SNF simulation for $0.47 \mathrm{~m}^{3} / \mathrm{s}\left(1,000 \mathrm{ft}^{3} / \mathrm{min}\right)$ primary flow $\left[0.38 \mathrm{~m}^{3} / \mathrm{s}\left(800 \mathrm{ft}^{3} / \mathrm{min}\right)\right.$ annulus and full-power mixer pump operation] is shown in Figure 4-5. The mixed-waste temperatures are approaching a steady-state temperature below the $91^{\circ} \mathrm{C}\left(195^{\circ} \mathrm{F}\right)$ limit. A linear interpolation suggests that a primary flow rate of between $0.33 \mathrm{~m}^{3} / \mathrm{s}\left(700 \mathrm{ft}^{3} / \mathrm{min}\right)$ and $0.38 \mathrm{~m}^{3} / \mathrm{s}$ $\left(800 \mathrm{ft}^{3} / \mathrm{min}\right)$ would result in a mixed-waste temperature equal to the temperature limit. Thus, a primary ventilation system flow rate larger than approximately $0.38 \mathrm{~m}^{3} / \mathrm{s}\left(800 \mathrm{ft}^{3} / \mathrm{min}\right)$ is needed to maintain the mixed-waste temperature below the temperature limit for continuous full-power pump operation.

Figure 4-5. Mixed-Waste Temperatures for $0.47 \mathrm{~m}^{3} / \mathrm{s}\left(1,000 \mathrm{ft}^{3} / \mathrm{min}\right)$ Primary Flow Rate.

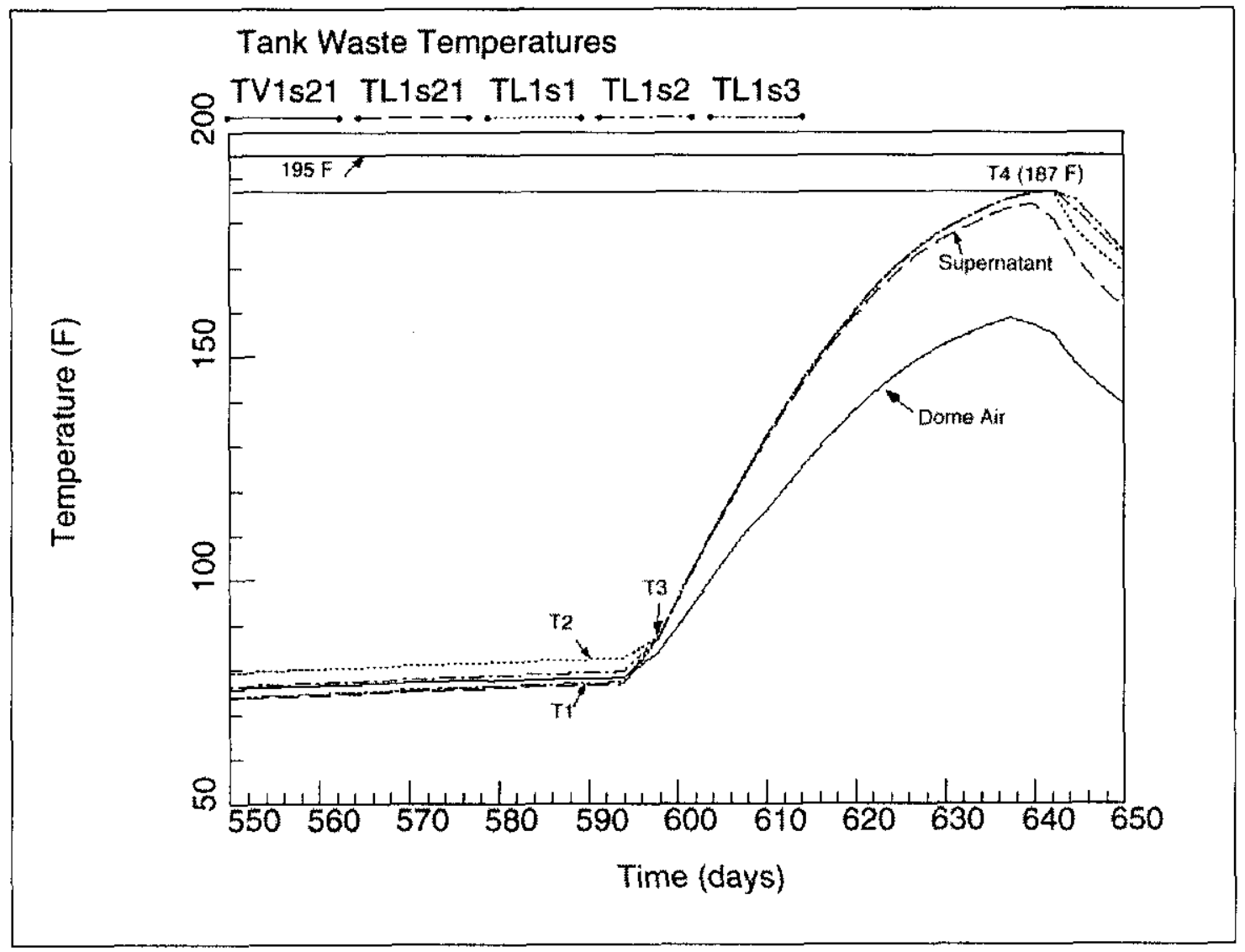

To convert ${ }^{\circ} \mathrm{F}$ to ${ }^{\circ} \mathrm{C}, t^{\circ} \mathrm{C}=\left(t_{\circ \mathrm{F}}-32\right) / 1.8$. 
The time for the mixed-waste temperature to reach the $91{ }^{\circ} \mathrm{C}\left(195^{\circ} \mathrm{F}\right)$ temperature limit are shown in Table 4-1, for the parametric cases where the predicted mixed-waste temperature exceeded the temperature limit (Cases D1 through D7). These data are shown graphically in Figure 4-6 for a range of primary ventilation flows. If the mixer pump run-time is limited to these values, the mixed-waste temperature will not exceed the temperature limit. Extrapolation of the curve in Figure 4-6 to zero primary ventilation flow [annulus system is still operating at $\left.0.38 \mathrm{~m}^{3} / \mathrm{s}\left(800 \mathrm{ft}^{3} / \mathrm{min}\right)\right]$ shows that the mixer pumps can operate for approximately 20 days with

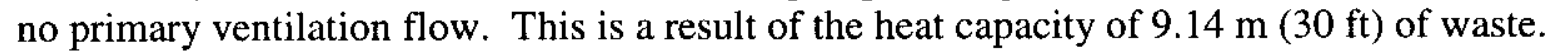

Figure 4-6. Time to Temperature Limit with Decanting and 100 Percent Pump Power.

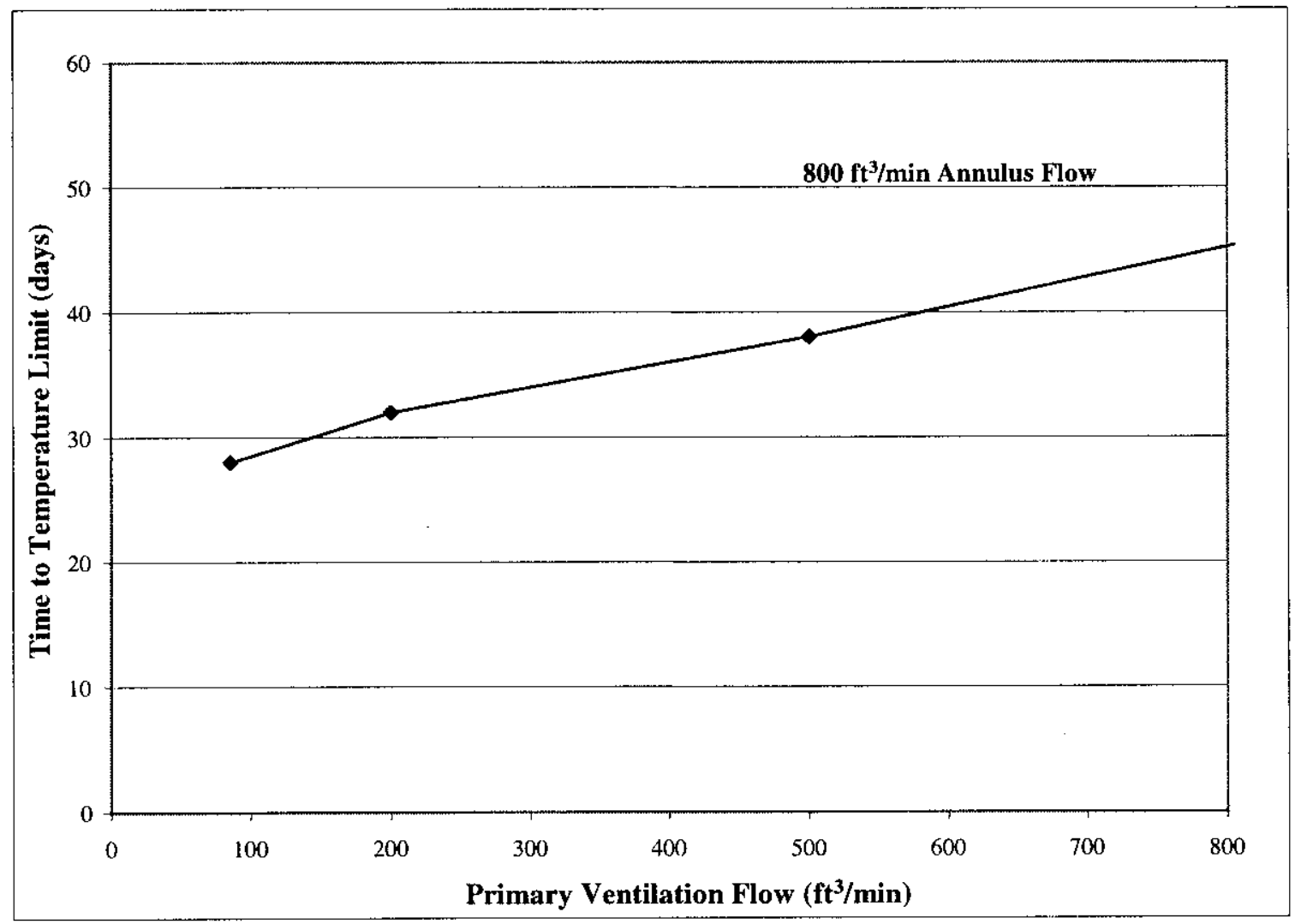

To convert $\mathrm{ft}^{3} / \mathrm{min}$ to $\mathrm{m}^{3} / \mathrm{s}$, multiply by $4.719474 \mathrm{E}-04$. 
Parametric analyses also were performed for reduced mixer pump power. These simulations are summarized in Table 4-1 (cases D12 through D19). The mixer pump power was reduced by 50 percent. This corresponds to a single mixer pump operating continuously at full power or two mixer pumps operating continuously at 50 percent power. The results shown in Table 4-1 demonstrate that the maximum mixed-waste temperatures are less than the temperature limit for range of primary and annulus ventilation flow rates. The analyses did not reach full steady-state before termination of the mixer pump operation. The actual steady temperatures may be 2.8 to $5.6^{\circ} \mathrm{C}\left(5\right.$ to $\left.10^{\circ} \mathrm{F}\right)$ higher than shown in Table $4-1$. These are still well below the temperature limit. These data are shown graphically in Figure 4-7. The Figure shows parametric analyses for the primary ventilation system flow for an annulus system flow rate of $0.38 \mathrm{~m}^{3} / \mathrm{s}\left(800 \mathrm{ft}^{3} / \mathrm{min}\right)$. The mixed-waste temperatures are below the temperature limit for primary ventilation flows less than $0.047 \mathrm{~m}^{3} / \mathrm{s}\left(100 \mathrm{ft}^{3} / \mathrm{min}\right)$. The reduced pump power results are compared with the full power pump operation in Figure 4-7. It can be seen that a reduction in mixer pump power dramatically reduces the mixed-waste temperature.

Figure 4-7. Maximum Mixed-Waste Temperature for Reduced Mixer Pump Power.

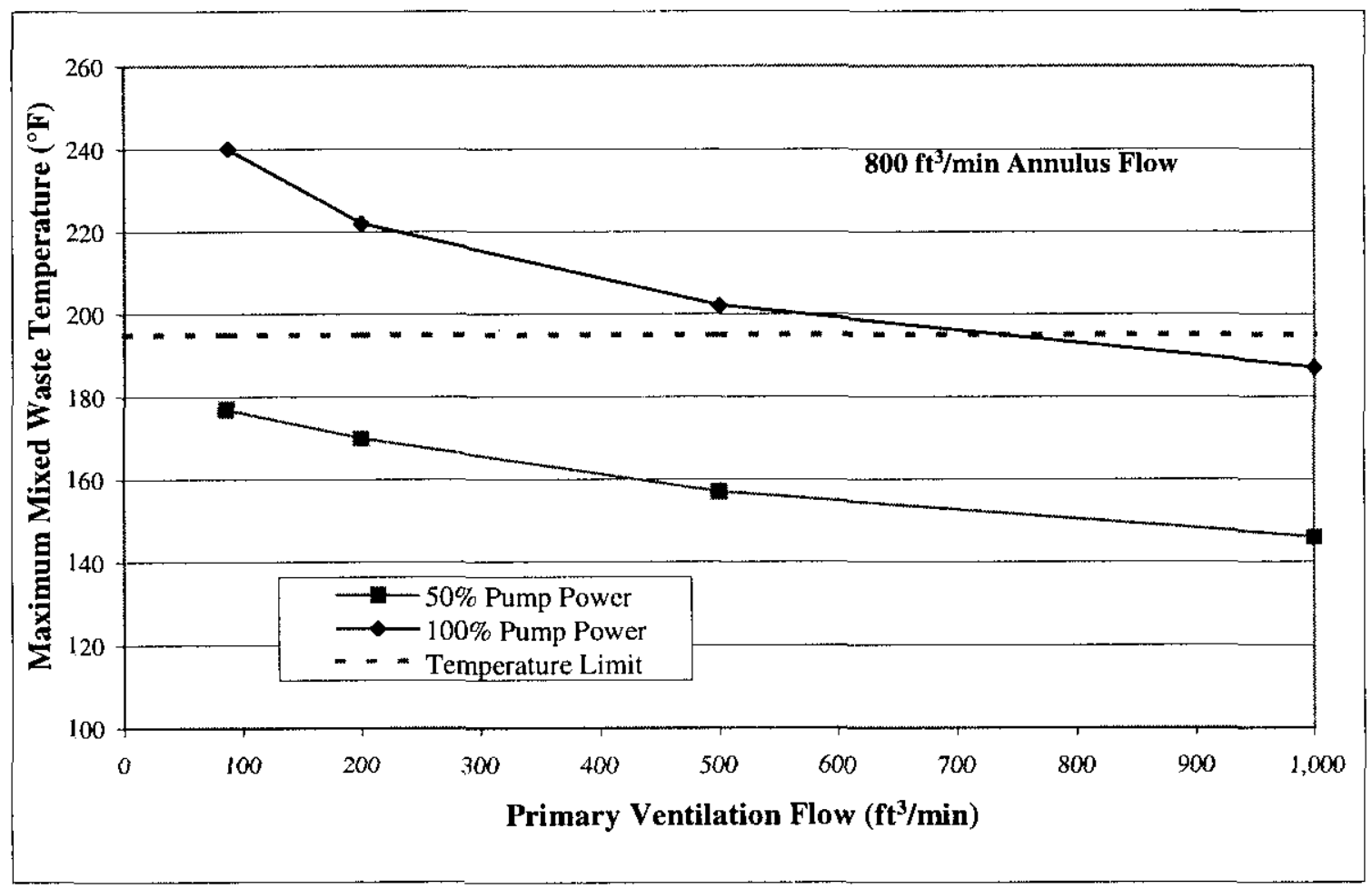

To convert $\mathrm{ft}^{3} / \mathrm{min}$ to $\mathrm{m}^{3} / \mathrm{s}$, multiply by $4.719474 \mathrm{E}-04$. 


\subsubsection{Annulus Ventilation Evaluation with Supernatant Decanting}

Parametric analyses also were performed to evaluate the annulus ventilation system for the bounding LAW tank. The annulus flow rates are summarized in Table 4-1. Parametric analyses were performed for a constant primary flow rate of $0.24 \mathrm{~m}^{3} / \mathrm{s}\left(500 \mathrm{ft}^{3} / \mathrm{min}\right)$ (Cases D3 through D7) and $0.47 \mathrm{~m}^{3} / \mathrm{s}\left(1,000 \mathrm{ft}^{3} / \mathrm{min}\right.$ ) (Cases D8 through D11). The results of the $0.24 \mathrm{~m}^{3} / \mathrm{s}$ $\left(500 \mathrm{ft}^{3} / \mathrm{min}\right)$ primary flow cases are shown in Figure $4-8$. The figure shows there is a $2.8^{\circ} \mathrm{C}$ $\left(5^{\circ} \mathrm{F}\right)$ temperature decrease in mixed-waste temperature as the annulus ventilation flow increases from $0 \mathrm{~m}^{3} / \mathrm{s}$ to $0.47 \mathrm{~m}^{3} / \mathrm{s}\left(1,000 \mathrm{ft}^{3} / \mathrm{min}\right)$. Clearly, the annulus ventilation system only has a second-order effect on the mixed-waste temperatures. During this portion of the retrieval operation, the primary ventilation system removes most the mixer pump heat through supernatant evaporation. The annulus ventilation system at summer conditions removes approximately 7 percent of the mixer pump heat [at $\left.0.38 \mathrm{~m}^{3} / \mathrm{s}\left(800 \mathrm{ft}^{3} / \mathrm{min}\right)\right]$. Thus, the effect of the annulus ventilation system on the mixed-waste temperature is small.

Figure 4-8. Annulus Flow Parametric for Maximum Mixed-Waste Temperature with Decanting and 100 Percent Pump Power.

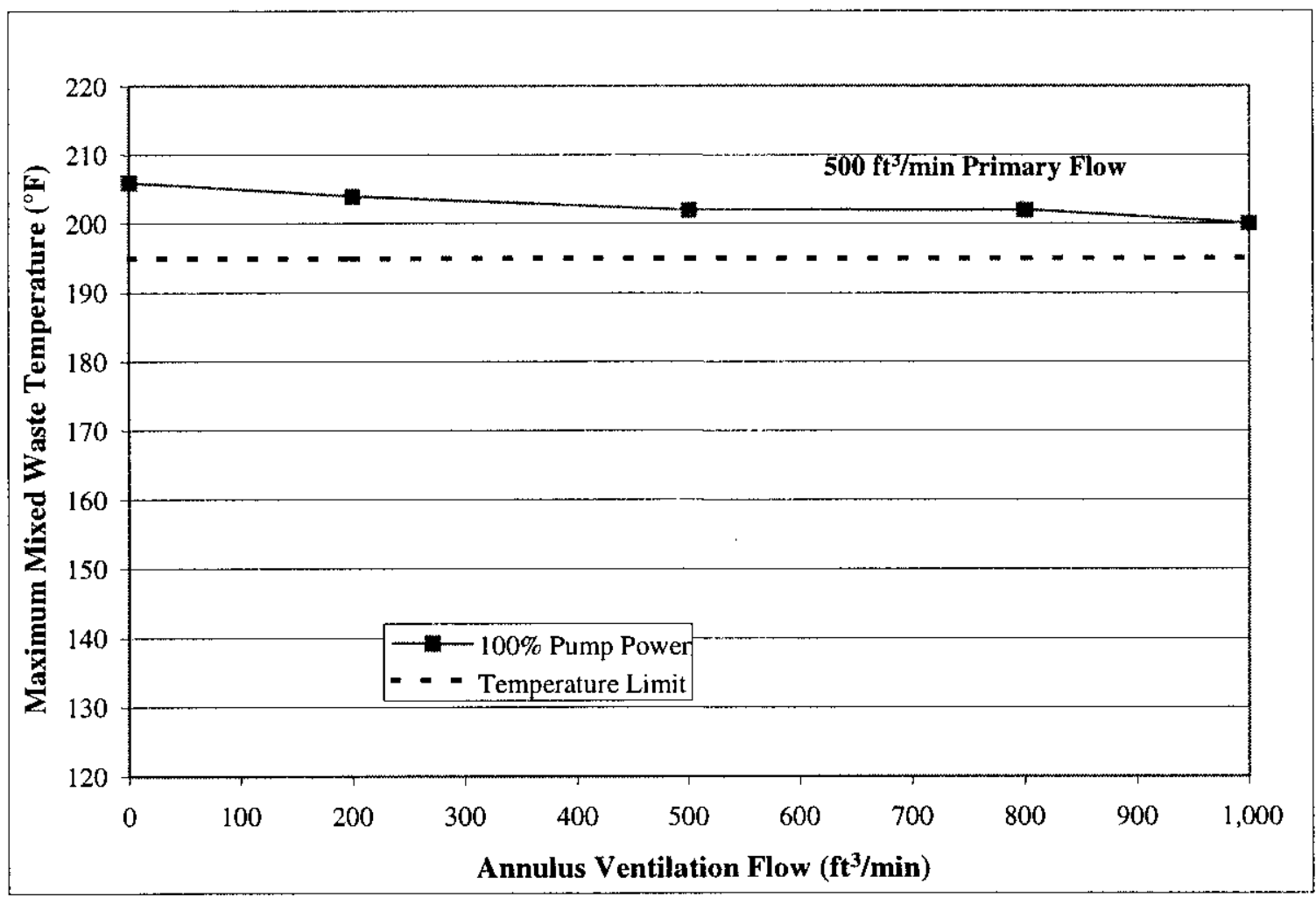

To convert $\mathrm{ft}^{3} / \mathrm{min}$ to $\mathrm{m}^{3} / \mathrm{s}$, multiply by $4.719474 \mathrm{E}-04$. 
The effect of the annulus ventilation system during mixer pump operation is further demonstrated in Figure 4-9. This figure shows the predicted time to reach the mixed-waste temperature limit for a range of annulus ventilation flows [with a constant $0.24 \mathrm{~m}^{3} / \mathrm{s}$ $\left(500 \mathrm{ft}^{3} / \mathrm{min}\right)$ primary ventilation flow rate]. The time to reach the temperature limit is increased by only 3 days as the annulus ventilation flow is increased from $0 \mathrm{~m}^{3} / \mathrm{s}$ to $0.47 \mathrm{~m}^{3} / \mathrm{s}$ $\left(1,000 \mathrm{ft}^{3} / \mathrm{min}\right)$. This again illustrates that during mixer pump operation the primary ventilation system is the most effective system for heat removal and the annulus system provides only limited heat removal.

Figure 4-9. Annulus Flow Parametric for Time to Temperature Limit with Decanting and 100 Percent Pump Power.

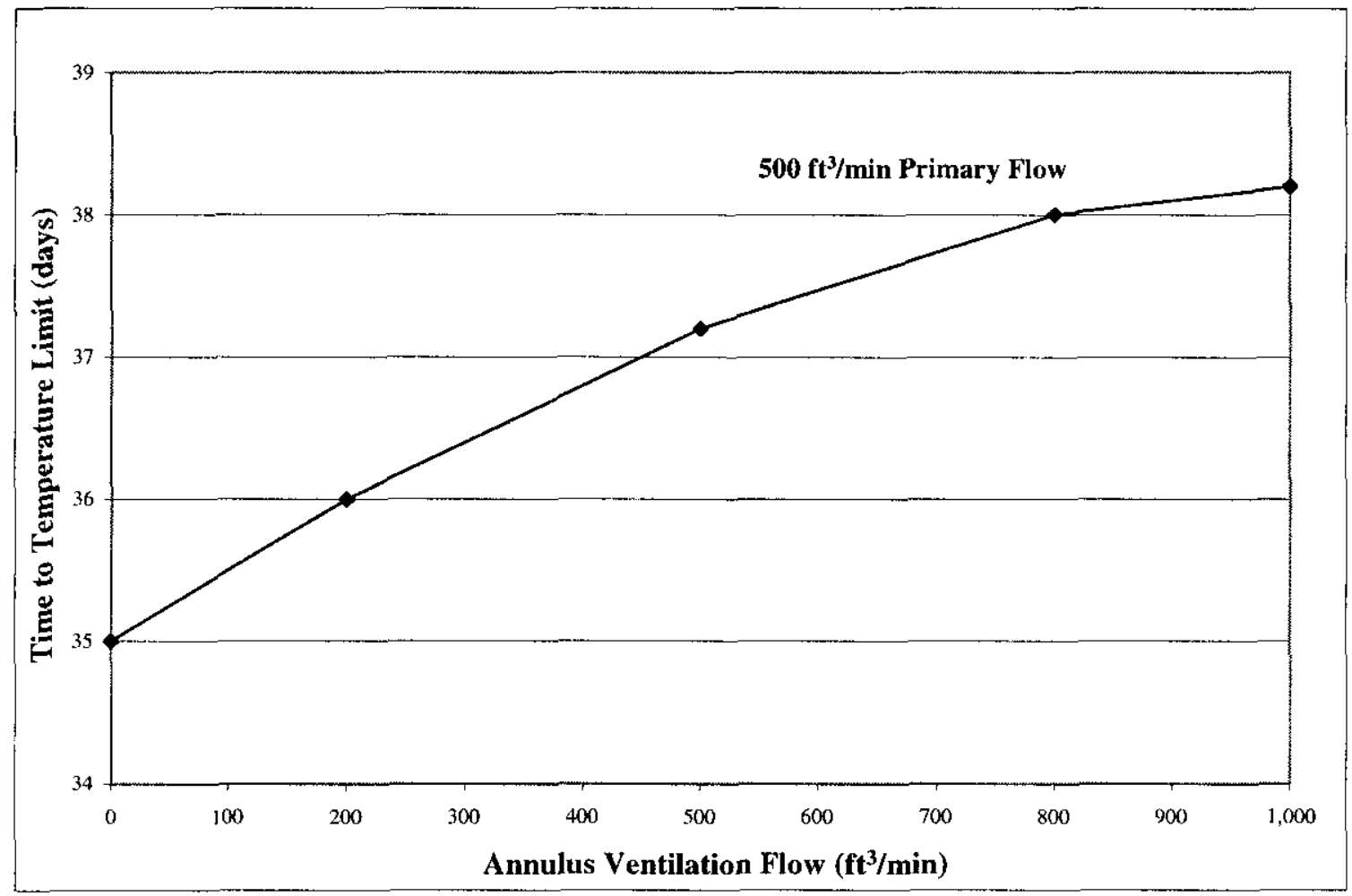

To convert $\mathrm{ft}^{3} / \mathrm{min}$ to $\mathrm{m}^{3} / \mathrm{s}$, multiply by $4.719474 \mathrm{E}-04$.

\subsubsection{Waste Resettling with Supernatant Decanting}

After the supernatant has been decanted and dilution water added to the tank, the mixer pump will mix the waste, resulting in dilution of the waste and a suspension of the undissolved waste into the supernatant. If mixer pump operation is suspended for any reason, the suspended waste will settle resulting in a settled solids layer. This waste is initially expected to settle to a fluffed state with the particle volume fraction less than the pre-mixed settled waste. A fluffing factor of 2.0 is assumed for these analyses. Subsequent compaction of the settled waste eventually will reduce the fluffing factor to unity. Waste compaction is not considered in the parametric analyses. With supernatant decanting strategy, a large fraction of the waste is expected to go into solution. Thus, even with a fluffing factor of 2.0 , the settled solids layer after mixer pump 


\section{RPP-5643 REV 0}

operation $[0.45 \mathrm{~m}(1.46 \mathrm{ft})]$ is significantly less than the pre-decanted settled waste layer $[3.66 \mathrm{~m}$ $(12 \mathrm{ft})]$.

The predicted resettled waste temperatures following the termination of mixer pump operation are shown in Figure 4-10. This analysis was performed for a primary ventilation flow rate of $0.94 \mathrm{~m}^{3} / \mathrm{s}\left(200 \mathrm{ft}^{3} / \mathrm{min}\right)$ and annulus system flow rate of $0.38 \mathrm{~m}^{3} / \mathrm{s}\left(800 \mathrm{ft}^{3} / \mathrm{min}\right)$. These are the nominal flows for both systems. The figure shows that the waste and supernatant temperatures decrease immediately after the mixer pump operation is stopped. The temperatures decrease to a new settled waste temperature in about 30 days. The temperature after waste resettling is higher than the pre-mixed temperatures. However, settled waste temperatures are well below the settled waste temperature limit of $102^{\circ} \mathrm{C}\left(215^{\circ} \mathrm{F}\right)$. The low temperature is a result of the small heat load for the LAW tanks and the dilution of the waste resulting from the supernatant decanting and subsequent mixing. This significantly reduces the settled solids depth.

Figure 4-10. Resettled Waste Temperatures with Decanting.

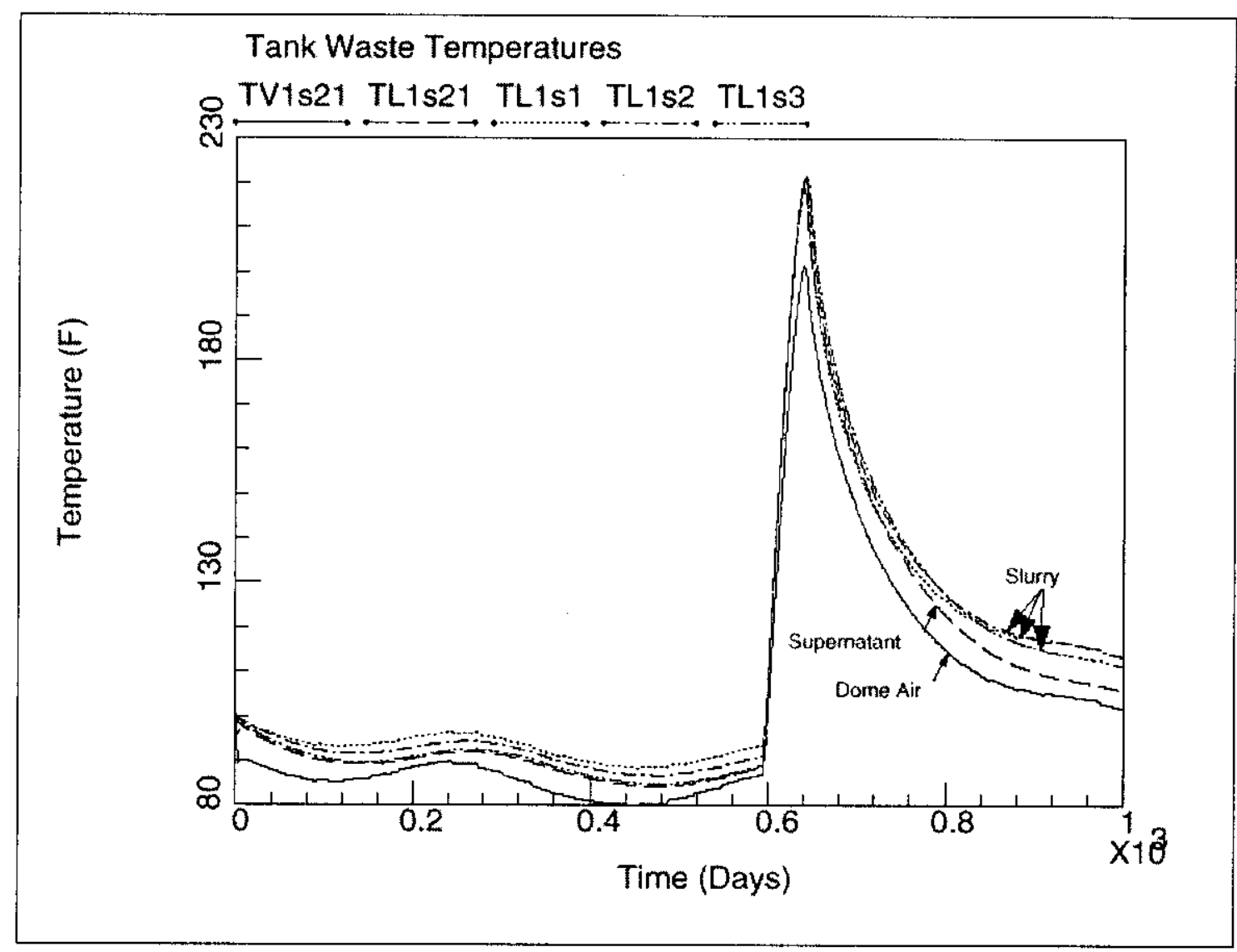

To convert ${ }^{\circ} \mathrm{F}$ to ${ }^{\circ} \mathrm{C}, t_{\circ} \mathrm{C}=\left(t_{\circ}-32\right) / 1.8$.

The settled waste temperatures are summarized in Table 4-1. These temperatures are well below the settled waste temperature limit for the parametric analyses. The nominal primary and annulus system flow rates of $0.094 \mathrm{~m}^{3} / \mathrm{s}\left(200 \mathrm{ft}^{3} / \mathrm{min}\right)$ and $0.38 \mathrm{~m}^{3} / \mathrm{s}\left(800 \mathrm{ft}^{3} / \mathrm{min}\right)$ flow provide significantly more cooling than required during waste resettling. Parametric cases D6 and D2 show the effect of primary ventilation flow on the resettled waste temperature. A reduction of $0.14 \mathrm{~m}^{3} / \mathrm{s}\left(300 \mathrm{ft}^{3} / \mathrm{min}\right)$ flow results in a $7.8^{\circ} \mathrm{C}\left(14^{\circ} \mathrm{F}\right)$ temperature increase in the waste 


\section{RPP-5643 REV 0}

temperature. Parametric case D3 shows that with $0.24 \mathrm{~m}^{3} / \mathrm{s}\left(500 \mathrm{ft}^{3} / \mathrm{min}\right)$ primary flow rate and 0 annulus flow, the resettled waste temperature is only $44.4^{\circ} \mathrm{C}\left(112^{\circ} \mathrm{F}\right)$. Thus, a primary flow of

$0.094 \mathrm{~m}^{3} / \mathrm{s}\left(200 \mathrm{ft}^{3} / \mathrm{min}\right)$ with no annulus ventilation flow should result in a settled waste temperature of approximately $52^{\circ} \mathrm{C}\left(126^{\circ} \mathrm{F}\right)$. This is well below the settled waste temperature limit of $90.6^{\circ} \mathrm{C}\left(195^{\circ} \mathrm{F}\right)$. The resettled waste temperatures with supernatant decanting will be below the temperature limit with only minimal primary ventilation flow.

The results of the parametric analyses can be used to evaluate the impact of a loss of ventilation cooling after waste resettling. The parametric analyses shown in Table 4-1 show that the resettled waste temperatures for the decanted cases are approximately $57^{\circ} \mathrm{C}\left(100^{\circ} \mathrm{F}\right)$ below the temperature limit of $102^{\circ} \mathrm{C}\left(215^{\circ} \mathrm{F}\right)$ and $57^{\circ} \mathrm{C}\left(135^{\circ} \mathrm{F}\right)$ below the $121^{\circ} \mathrm{C}\left(250^{\circ} \mathrm{F}\right) \mathrm{TSR}$ limit. Figure 4-6 shows that with no primary ventilation flow, it takes nearly 25 days to heat the mixed-waste temperature more than $56^{\circ} \mathrm{C}\left(100^{\circ} \mathrm{F}\right)$ to the mixed-waste temperature limit. This heat rate is accomplished with $440 \mathrm{~kW}(1,500,000 \mathrm{BTU} / \mathrm{h})$ of pump heat. The heat load for tank 241-AN-103 is less than $11.7 \mathrm{~kW}(40,000 \mathrm{BTU} / \mathrm{h})$ (Table 2-4). It would clearly take many months to heat the settled waste to temperatures approaching the TSR limit, providing sufficient time to restore lost ventilation cooling. The risk of exceeding the TSR limit for a loss of ventilation flow, following mixing with decanting, is negligible.

\subsection{MIXER PUMP OPERATION WITHOUT SUPERNATANT DECANTING}

As described in Section 2.3.3, mixer pump operation without supernatant decanting assumes that the pumps are placed in the tank, then the waste is mixed and allowed to resettle. Mixer pump operation without supernatant decanting results in more dissolved waste in the supernatant, higher vapor suppression (30 percent of water compared with 60 percent of water for the decanted supernatant after waste mixing) and less settled waste dissolved into the supernatant. Therefore, the resettled solid layer is thicker after pump operation. Although this is not the expected retrieval scenario, it provides a conservative assessment of requirements for the primary and annulus ventilation systems. This scenario also provides a parametric study for the effects of waste dilution.

Parametric analyses were performed for both the primary and annulus ventilation systems. The results of 14 parametric analyses are summarized in Table 4-2. The primary ventilation evaluation is presented in Section 4.2.1, and the annulus ventilation system evaluation is presented in Section 4.2.2.

Table 4-2 summarizes the predicted maximum, mixed-waste temperature during mixer pump operation. The predicted mixed-waste temperatures shown in Table 4-2 exceed the temperature limit for primary ventilation flows up to $0.47 \mathrm{~m}^{3} / \mathrm{s}\left(1,000 \mathrm{ft}^{3} / \mathrm{min}\right)$. The mixed-waste temperatures are below the mixed-waste temperature limit for a primary ventilation flow of $1.42 \mathrm{~m}^{3} / \mathrm{s}\left(3,000 \mathrm{ft}^{3} / \mathrm{min}\right)$. The requirement for higher primary ventilation flow (compared with the decanted case) is a direct result of the larger supernatant vapor suppression, which reduces the effectiveness of evaporation cooling. The time to reach the temperature limit is shown in the last column of the table. 


\section{RPP-5643 REV 0}

The results of the predicted settled waste temperatures are not shown in Table 4-2 but are presented in Section 4.3.3.

Table 4-2. Summary of Results for Nondecanted Cases.

\begin{tabular}{|c|c|c|c|c|c|c|}
\hline \multirow[b]{2}{*}{ Pump Power } & \multirow[b]{2}{*}{$\begin{array}{l}\text { Primary } \\
\text { fow } / \mathrm{m} / \mathrm{s} \\
(\mathrm{m} / \mathrm{min})\end{array}$} & \multirow[b]{2}{*}{$\begin{array}{c}\text { Annulus } \\
\text { Flow m/s } \\
\left(\mathrm{ft}^{3} / \mathrm{min}\right)\end{array}$} & \multirow[b]{2}{*}{ Run No. } & \multicolumn{3}{|c|}{ Pump Operation } \\
\hline & & & & $\begin{array}{l}\text { Mixed Waste } \\
\text { Temperature } \\
\text { oC (o F) } \\
\text { [91 \&C (195 F) } \\
\text { Temp Limit] }\end{array}$ & $\begin{array}{l}\text { Time to Reach } \\
\text { Temperature Limit } \\
\text { (Days) }\end{array}$ & $\begin{array}{l}\text { Moisture Garryover } \\
\mathrm{kg} / \mathrm{s}(\mathrm{bm} / \mathrm{h})\end{array}$ \\
\hline \multirow{8}{*}{$100 \%$} & $0.04(85.7)$ & $0.38 \quad(800)$ & UD1 & $>91(195)$ & 23 & $0.0073(58)$ \\
\hline & $0.094(200)$ & $0.38 \quad(800)$ & UD2 & $>91(195)$ & 25 & $0.0168(133)$ \\
\hline & $0.24(500)$ & $0.38 \quad(800)$ & UD3 & $>91(195)$ & 27 & $0.318(252)$ \\
\hline & \multirow{2}{*}{$0.47(1,000)$} & $0.38 \quad(800)$ & UD4 & $>91(195)$ & 30 & $0.09(713)$ \\
\hline & & $0.47(1,000)$ & UD5 & $>91(195)$ & 31 & $0.69(55 t)$ \\
\hline & \multirow{3}{*}{$1.42(3000)$} & 0 & UD6 & $87(189)$ & $\mathrm{NA}$ & $0.136(1080)$ \\
\hline & & $0.24(500)$ & UD7 & $87(188)$ & NA & $0.13(1030)$ \\
\hline & & $0.38 \quad(800)$ & UD8 & $86(187)$ & NA & $0.127(1010)$ \\
\hline \multirow{6}{*}{$50 \%$} & $0.04(85.7)$ & $0.38 \quad(800)$ & UD9 & $>91(195)$ & 49 & $0.0066(52)$ \\
\hline & $0.24(500)$ & $0.38 \quad(800)$ & UD10 & $>91(195)$ & 57 & $0.0218(173)$ \\
\hline & \multirow{4}{*}{$0.47(1,000)$} & 0 & UDI! & $>91(195)$ & 65 & $0.0386(306)$ \\
\hline & & $0.094(200)$ & UD12 & $>91(195)$ & 66 & $0.0354(281)$ \\
\hline & & $0.24(500)$ & UD13 & $>91(195)$ & 69 & $0.0326(259)$ \\
\hline & & $0.38(800)$ & UDI 4 & $>91(195)$ & 72 & 245 \\
\hline
\end{tabular}




\subsubsection{Primary Ventilation Evaluation without Supernatant Decanting}

The GOTH_SNF analyses of the bounding LAW tank for $0.094 \mathrm{~m}^{3} / \mathrm{s}\left(200 \mathrm{ft}^{3} / \mathrm{min}\right)$ primary flow and $0.38 \mathrm{~m}^{3} / \mathrm{s}\left(800 \mathrm{ft}^{3} / \mathrm{min}\right)$ annulus flow and full-power mixer pump operation, is shown in Figure 4-11. The mixer pump operation begins 595 days from the beginning of the simulation. The first portion of the analyses was used to initialize the waste and soil. The full-power pump heat results in a rapid increase in mixed-waste temperature. The large vapor suppression (30 percent of water) significantly reduces heat removal by evaporation, which decreases the effectiveness of the primary ventilation system. The mixed-waste temperatures exceed the $91{ }^{\circ} \mathrm{C}$ $\left(195^{\circ} \mathrm{F}\right)$ temperature limit in 25 days.

Figure 4-11. Typical Mixed-Waste Temperatures without Supernatant Decanting.

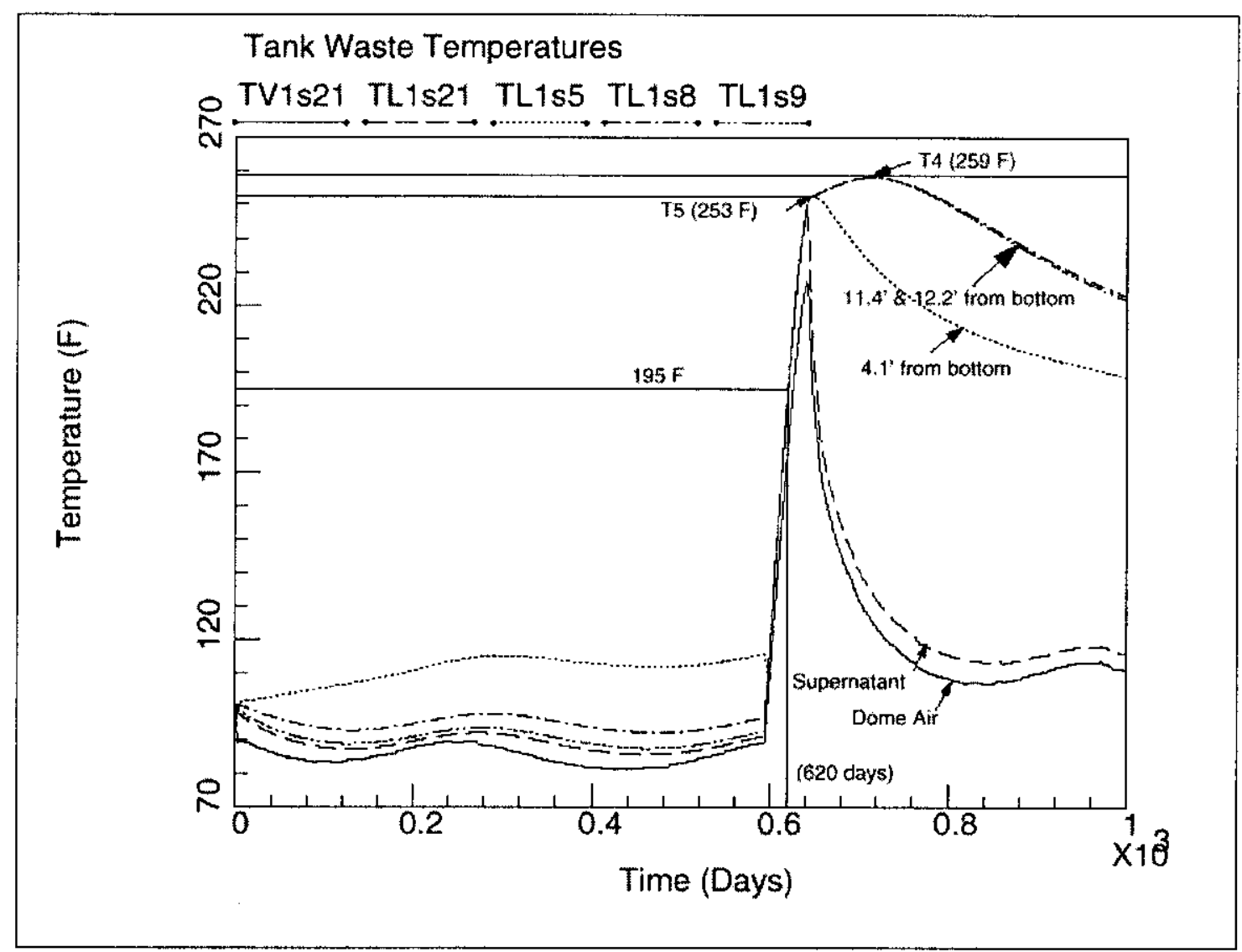

To convert ${ }^{\circ} \mathrm{F}$ to ${ }^{\circ} \mathrm{C}, t^{{ }^{\circ} \mathrm{C}}=\left(t_{\circ \mathrm{F}}-32\right) / 1.8$. 


\section{RPP-5643 REV 0}

The results of the parametric analyses for full-power pump operation are shown in Table 4-2 (parametric analyses UD1 through UD8). The predicted mixed-waste temperatures exceed the temperature limit for the parametric analyses. The time to reach the temperature limit is also summarized in Table 4-2. Figure 4-12 shows the result of parametric analyses for the primary ventilation system, with a constant $0.38 \mathrm{~m}^{3} / \mathrm{s}\left(800 \mathrm{ft}^{3} / \mathrm{min}\right)$ annulus flow rate. Increasing the primary ventilation from $0.47 \mathrm{~m}^{3} / \mathrm{s}\left(1,000 \mathrm{ft}^{3} / \mathrm{min}\right)$ to $1.42 \mathrm{~m}^{3} / \mathrm{s}\left(3,000 \mathrm{ft}^{3} / \mathrm{min}\right)$ decreases the maximum mixed-waste temperature to below the temperature limit. Figure 4-12 compares the decanted and nondecanted cases. The effect of the increased supernatant vapor suppression is significant. Although the nondecanted case is conservative, and not consistent with the expected retrieval scenario, it provides parametric analyses for the supernatant vapor suppression.

Parametric analyses were performed for reduced mixer pump power (50 percent of full power). The results of these analyses are shown in Table 4-2 (case UD9 through UD14). The mixed-waste temperatures exceed the temperature limit for annulus ventilation flows up to $0.47 \mathrm{~m}^{3} / \mathrm{s}\left(1,000 \mathrm{ft}^{3} / \mathrm{min}\right)$. The times to reach the temperature limit are doubled because of the 50 percent reduction in mixer pump power. The time to reach the temperature limit for the 50 percent pump power is shown in Figure 4-12.

Figure 4-12. Time to Temperature Limit Without Decanting.

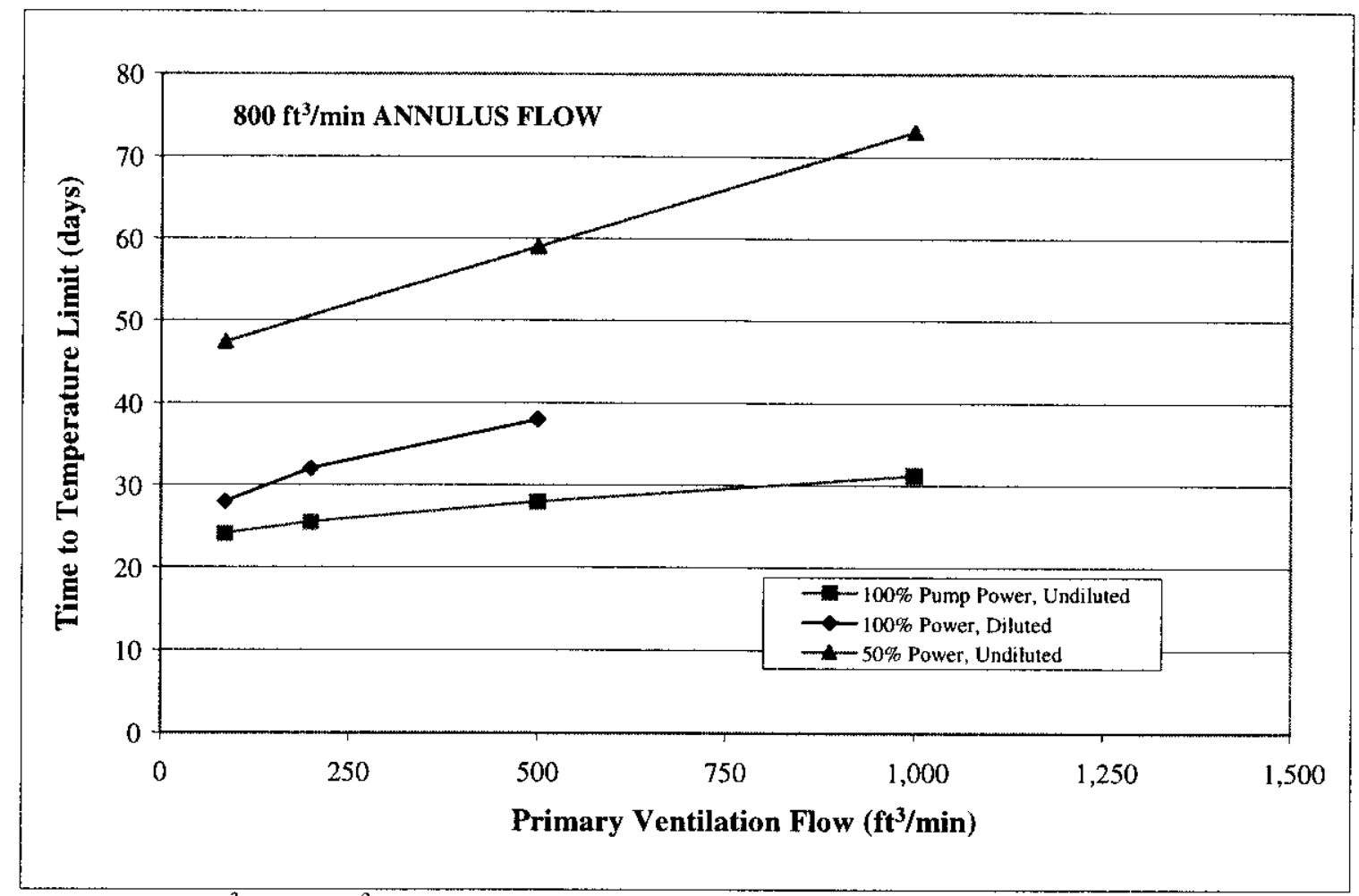

To convert $\mathrm{ft}^{3} / \mathrm{min}$ to $\mathrm{m}^{3} / \mathrm{s}$, multiply by 0.0283 . 


\subsubsection{Annulus Ventilation Evaluation without Supernatant Decanting}

Parametric analyses were performed for the annulus ventilation system for full pump power operation. The results are summarized in Table 4-2 (cases UD11 through UD14) and shown in Figure 4-13. The primary ventilation system flow rate was constant at $0.47 \mathrm{~m}^{3} / \mathrm{s}\left(1,000 \mathrm{ft}^{3} / \mathrm{min}\right)$. These analyses were performed for 50 percent mixer pump power. The results are similar to the decanted cases. Annulus ventilation flow rates up to $0.47 \mathrm{~m}^{3} / \mathrm{s}\left(1,000 \mathrm{ft}^{3} / \mathrm{min}\right)$ make only a small change in the time to reach the temperature limit. Comparisons with Table 4-1 (cases D3 through D7) show that the effect is larger for the nondecanted cases than the decanted cases. This is a result of the diminished heat removal of the primary system because of the increased vapor suppression. The primary ventilation, however, still dominates the heat removal during the mixer pump operation.

Figure 4-13. Annulus Ventilation Parametric for Time to Temperature with Decanting and 50 Percent Pump Power.

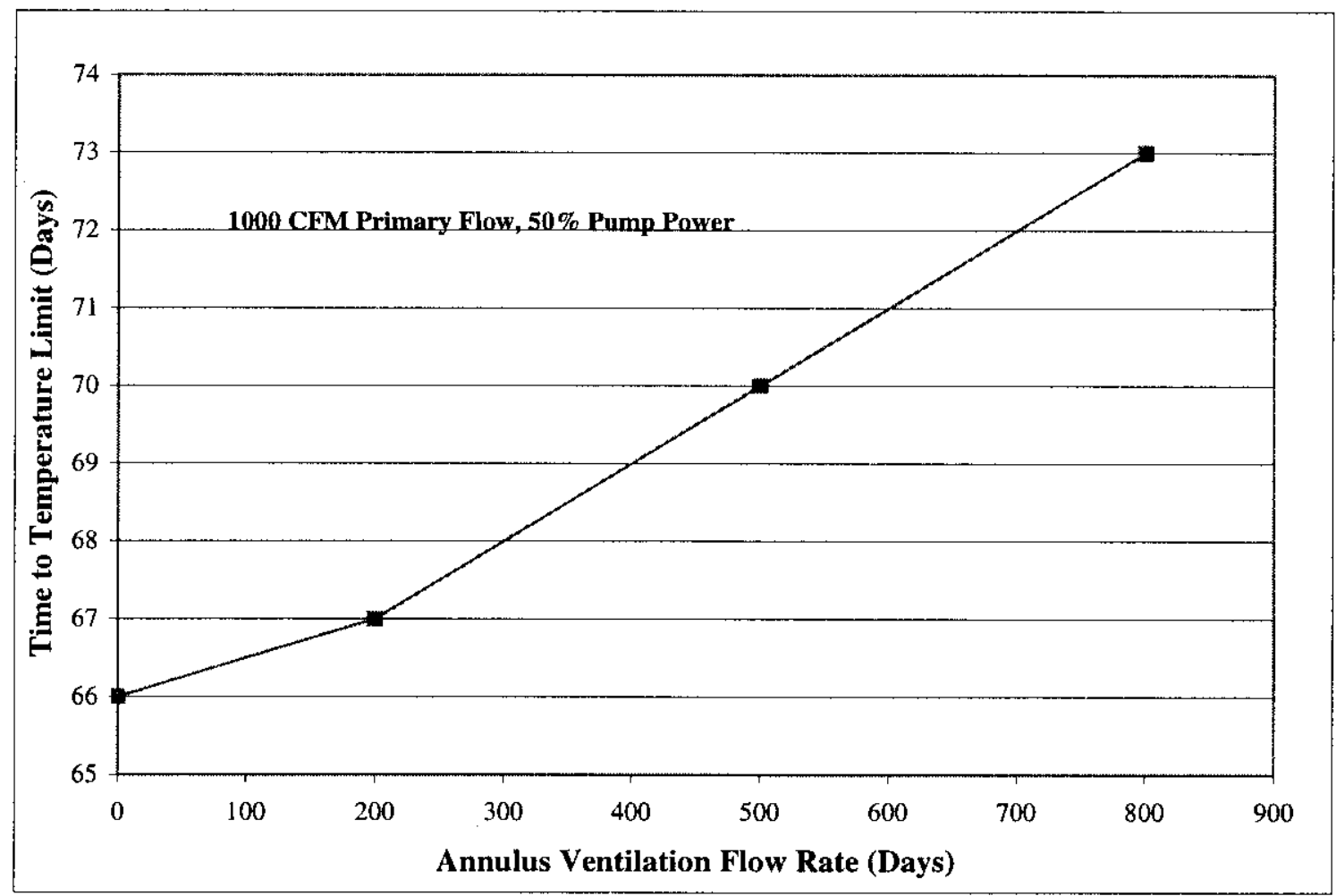

To convert $\mathrm{ft}^{3} / \mathrm{min}$ to $\mathrm{m}^{3} / \mathrm{s}$, multiply by 0.0283 .

\subsubsection{Waste Resettling without Supernatant Decanting}

The post mixer pump operation and subsequent waste resettling were evaluated for the nondecanted waste (no supernatant decanting). The GOTH_SNF analyses for $0.094 \mathrm{~m}^{3} / \mathrm{s}$ $\left(200 \mathrm{ft}^{3} / \mathrm{min}\right)$ primary flow rate and $0.38 \mathrm{~m}^{3} / \mathrm{s}\left(800 \mathrm{ft}^{3} / \mathrm{min}\right)$ annulus flow rate are shown in Figure 4-11. The resettled waste depth without supernatant decanting is $7.19 \mathrm{~m}(23.6 \mathrm{ft})$ (Table 2-5). The waste resettled waste depth for decanted cases is less than $0.61 \mathrm{~m}(2 \mathrm{ft})$. 


\section{RPP-5643 REV 0}

The effect of the larger waste depth can be seen by comparing Figures 4-10 and 4-11. The waste and supernatant temperature decrease immediately after the mixer pump operation is ended for the decanted cases. For the nondecanted cases, the temperature increases initially and then decreases more slowly. The initial increase for the nondecanted parametric analyses is less than $5.6^{\circ} \mathrm{C}\left(10^{\circ} \mathrm{F}\right)$. If the mixer pumps are stopped before the mixed-waste temperatures reach the $91^{\circ} \mathrm{C}\left(195^{\circ} \mathrm{F}\right)$ limit, the resettled waste for the bottom $4.57 \mathrm{~m}(15 \mathrm{ft})$ will not exceed the $102^{\circ} \mathrm{C}$ $\left(215^{\circ} \mathrm{F}\right)$ settled waste temperature limit. However, it should be noted that mixer pump operation should be ended at least $5.6^{\circ} \mathrm{C}\left(10^{\circ} \mathrm{F}\right)$ below the mixed-waste temperature limit. This will prevent the settled waste temperatures for the top $4.57 \mathrm{~m}(15 \mathrm{ft})$ of the waste from exceeding the $91^{\circ} \mathrm{C}\left(195^{\circ} \mathrm{F}\right)$.

The analyses were not run to complete steady state conditions. Figure 4-11 shows that the waste has not reached thermal equilibrium after 400 days. These analyses assume a fluffing factor of 2.0 with no waste compaction. The assumption of no compaction is not valid after such long periods.

\subsection{PRIMARY VENTILATION MOISTURE CARRYOVER}

This evaluation was performed through comparison of predicted waste temperatures with applicable temperature limits. The moisture carryover (mass of steam carried from the tank dome space by the primary ventilation system) is not a consideration for safety limits; however, moisture carryover is an important parameter for the design and operation of the primary ventilation system. This section provides an overview of this important parameter for the parametric analyses performed for tank 241-AN-103. 


\section{RPP-5643 REV 0}

The results of the predicted moisture carryover are summarized in Tables 4-1 and 4-2. The values shown in the tables are the moisture carryover at the steady-state supernatant temperature during mixer pump operation. If the supernatant temperature exceeded the temperature limit, the value reported in the tables is the moisture carryover at the mixed-waste temperature limit of $90.6^{\circ} \mathrm{C}\left(195^{\circ} \mathrm{F}\right)$. The moisture carryover for $0.47 \mathrm{~m}^{3} / \mathrm{s}\left(1,000 \mathrm{ft}^{3} / \mathrm{min}\right)$ primary and $0.38 \mathrm{~m}^{3} / \mathrm{s}$ $\left(800 \mathrm{ft}^{3} / \mathrm{min}\right)$ annulus flow rate with full-power pump operation is shown in Figure 4-14.

Moisture carryover only becomes important during the mixer pump operation. Figure 4-14 shows that the moisture carryover reaches a maximum near $0.136 \mathrm{~kg} / \mathrm{s}(0.3 \mathrm{lbm} / \mathrm{s})$. This is approximately $0.000131 \mathrm{~m}^{3} / \mathrm{s}(125 \mathrm{gal} / \mathrm{h})$.

Figure 4-14. Predicted Moisture Carryover for Nominal Ventilation Flow.

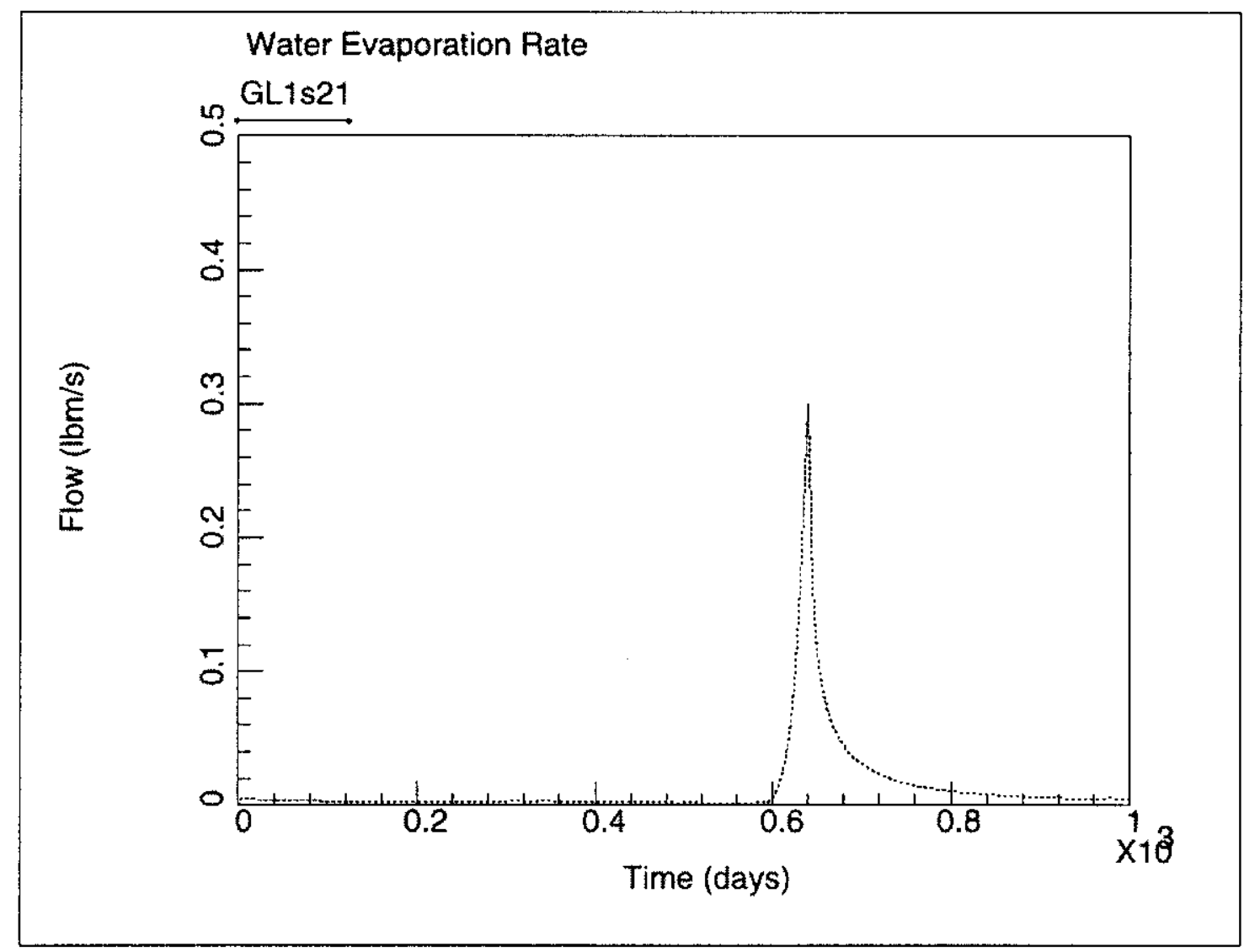

To convert $\mathrm{lbm} / \mathrm{s}$ to $\mathrm{kg} / \mathrm{s}$, multiply by 0.454 . 


\section{RPP-5643 REV 0}

The moisture carry over is a strong function of the primary flow rate. Figure 4-15 shows the predicted moisture carryover as a function of primary ventilation flow for 50 percent and 100 percent mixer pump power. The annulus system flow was a constant $0.38 \mathrm{~m}^{3} / \mathrm{s}$ $\left(800 \mathrm{ft}^{3} / \mathrm{min}\right)$. The figure shows that the moisture carryover increases significantly with primary ventilation flow, as expected, and decreases significantly with reduced mixer pump power.

Figure 4-15 shows the predicted moisture carryover for $0.38 \mathrm{~m}^{3} / \mathrm{s}\left(800 \mathrm{ft}^{3} / \mathrm{min}\right)$ annulus flow rate with full-power pump operation without supernatant decanting. The vapor suppression for the nondecanted case is 50 percent of the suppression for the decanted case (Table 2-3). The lower evaporation rate is comparable to the 50 percent pump power with supernatant decanting.

Figure 4-15. Moisture Carryover for Primary Ventilation Flows.

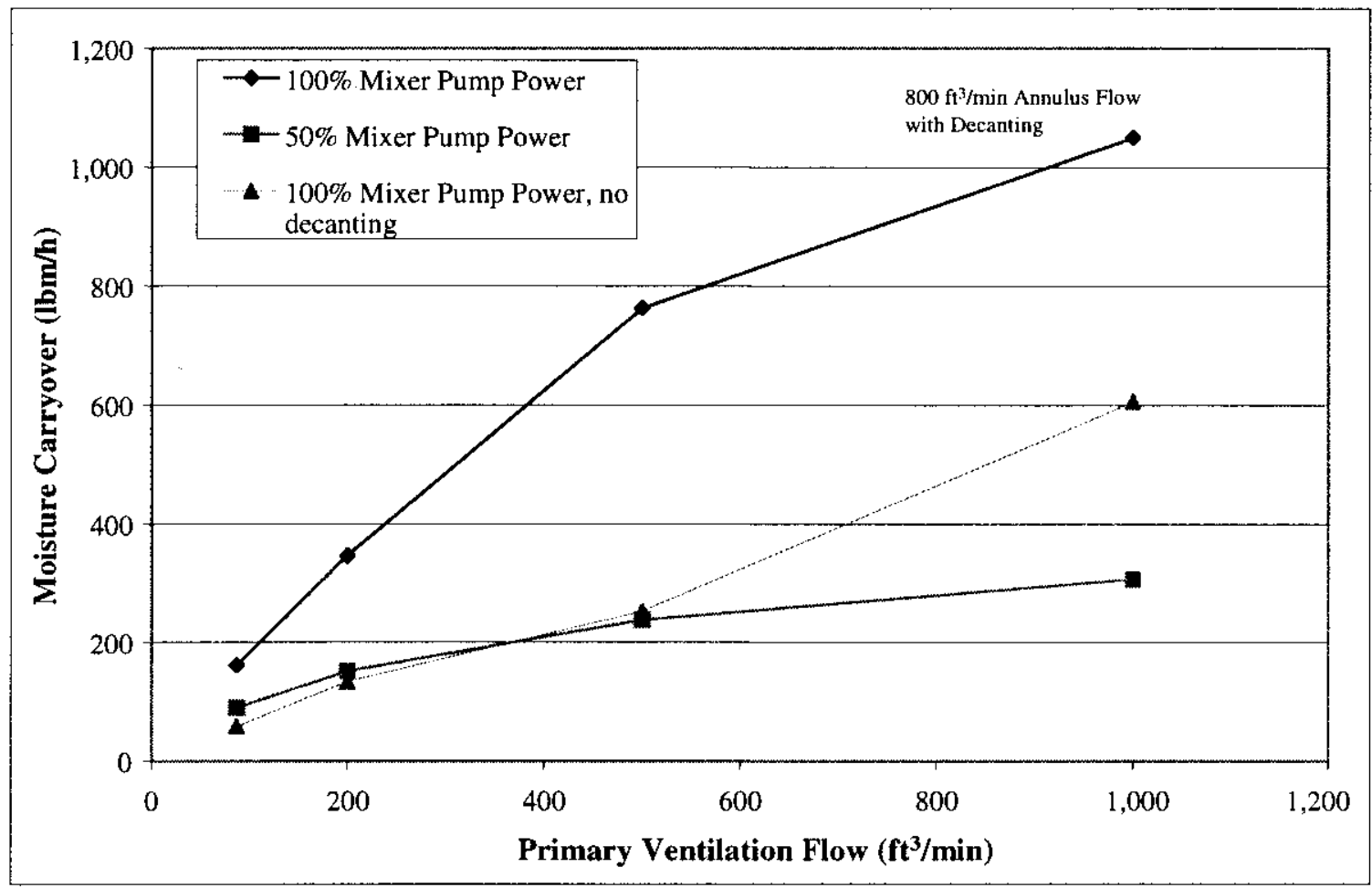

To convert $\mathrm{lbm} / \mathrm{s}$ to $\mathrm{kg} / \mathrm{s}$, multiply by 0.454 .

To convert $\mathrm{ft}^{3} / \mathrm{min}$ to $\mathrm{m}^{3} / \mathrm{s}$, multiply by 0.0283 . 


\section{RPP-5643 REV 0}

\subsection{CONCLUSIONS}

\subsection{RETRIEVAL WITH SUPERNATANT DECANTING}

The following conclusions are derived from the parametric analyses with decanting the supernatant and back filling the tank with water before mixer pump operation.

1. The minimum primary ventilation system flow is between $0.33 \mathrm{~m}^{3} / \mathrm{s}\left(700 \mathrm{ft}^{3} / \mathrm{min}\right)$ and $0.38 \mathrm{~m}^{3} / \mathrm{s}\left(800 \mathrm{ft}^{3} / \mathrm{min}\right)$ to keep the waste below the LCS/LCO temperature limit when operating two mixer pumps at full power indefinitely.

2. The number of days of full-power mixer pump operation possible before reaching the LCS/LCO temperature limit is very sensitive to primary ventilation system flow.

- The mixer pumps may operate up to 20 days with no primary ventilation system flow.

- The mixer pumps may operate up to 34 days with a primary ventilation system flow of $0.094 \mathrm{~m}^{3} / \mathrm{s}\left(200 \mathrm{ft}^{3} / \mathrm{min}\right)$.

- Mixer pump operating time is not limited with a primary ventilation system flow of $0.47 \mathrm{~m}^{3} / \mathrm{s}\left(1,000 \mathrm{ft}^{3} / \mathrm{min}\right)$.

3. Mixer pump operating time is not limited when operating at 50 percent power as long as the primary ventilation system flow is greater than $0.04 \mathrm{~m}^{3} / \mathrm{s}\left(90 \mathrm{ft}^{3} / \mathrm{min}\right)$.

4. The maximum waste temperature reached during full-power mixer pump operation is insensitive to annulus ventilation system flow.

\subsection{RETRIEVAL WITHOUT SUPERNATANT DECANTING}

The following conclusions are derived from the parametric analyses if the supernatant is not decanted before mixer pump operation.

1. The decreased vapor pressure resulting from not decanting decreases the allowable full-power mixer pump time of operation significantly.

2. The maximum waste temperature reached during full-power mixer pump operation is insensitive to annulus ventilation system flow.

3. A primary ventilation system flow near $1.42 \mathrm{~m}^{3} / \mathrm{s}\left(3,000 \mathrm{ft}^{3} / \mathrm{min}\right)$ is required for unlimited full-power mixer pump operation

4. Mixer pump operating time is limited even when operating at 50 percent power for primary ventilation flow rates less than or equal to $0.47 \mathrm{~m}^{3} / \mathrm{s}\left(1,000 \mathrm{ft}^{3} / \mathrm{min}\right)$. 


\section{RPP-5643 REV 0}

This page intentionally left blank. 


\subsection{RECOMMENDATIONS}

The following recommendations are based on the results of this parametric analysis for LAW feed retrieval.

1. It is recommended that the primary ventilation system be designed to provide a minimum of $0.094 \mathrm{~m}^{3} / \mathrm{s}\left(200 \mathrm{ft}^{3} / \mathrm{min}\right)$ for heat removal when the mixer pumps are operating.

Basis: The mixer pumps can be operated at full power approximately 32 days for decanted case and 27 days for the nondecanted case with a primary ventilation system flow of $0.094 \mathrm{~m}^{3} / \mathrm{s}\left(200 \mathrm{ft}^{3} / \mathrm{min}\right)$. This flow rate is within the existing system capability and provides a design factor of 3 over the estimated 10 days for dissolution of soluble waste. Increasing the flow rate for heat removal to $0.24 \mathrm{~m}^{3} / \mathrm{s}\left(500 \mathrm{ft}^{3} / \mathrm{min}\right)$ increases the pump operating time insignificantly (approximately 3 days and is not a sufficient basis for increasing the capability of the installed systems). It should be noted that other drivers (e.g., maintaining vacuum with risers open) might require increased capacity. Evaluation of these other drivers, however, is outside the scope of this analysis.

2. It is recommended that the annulus ventilation system be designed to be capable of providing a minimum of $0.094 \mathrm{~m}^{3} / \mathrm{s}\left(200 \mathrm{ft}^{3} / \mathrm{min}\right)$ flow.

Basis: Although the analyses show that no annulus flow is required during mixer pump operation, the analysis is insufficient to determine that no flow will ever be required. For instance, this analysis did not address off-normal events that may require annulus flow to mitigate them (e.g., loss of primary cooling). In addition, the recommended flow rate will be sufficient to continue using the CAMs for leak detection. Lastly, this flow is sufficient to maintain the flexibility to retrieve a tank of waste without decanting first. Additional analysis might show that the temperature in the solids could be controlled adequately without annulus flow. 
RPP-5643 REV 0

This page intentionally left blank. 


\subsection{REFERENCES}

HNF-5177, 1999, The Settling and Compaction of Nuclear Waste Slurries, Rev. 0, Fluor Daniel Hanford, Inc., Richland, Washington.

HNF-SD-WM-TSR-006, 1999, Tank Waste Remediation System Technical Safety Requirements, Rev. 1, Fluor Daniel Hanford, Inc., Richland, Washington.

JMI-980306-1, 1999, Quality Assurance Manual And Procedures, Rev. 3, John Marvin, Inc., West Richland, Washington.

JMI-980306-2, 1999, Users' Manual for GOTH_SNF Version 5.0, Rev. 1, John Marvin, Inc., West Richland, Washington.

JMI-980306-3, 1999, Technical Manual For GOTH_SNF Version 5.0, Rev. 1, John Marvin, Inc., West Richland, Washington.

JMI-9911-01, 2000, Notebook for GOTH_SNF Simulations for Tank AN-IO3 During and After Mixer Pump Operation, John Marvin, Inc., West Richland, Washington.

RPP-5637, 2000, Parametric Analysis of Heat Removal from High-Level Waste Tanks, Rev. 0, Numatec Hanford Corporation, Richland, Washington. 
RPP-5643 REV 0

This page intentionally left blank. 
RPP-5643 REV 0

APPENDIX A

TANK SELECTION FOR A PARAMETRIC STUDY TO CHARACTERIZE LOW-LEVEL WASTE TANK HEAT REMOVAL ALTERNATIVES FOR PHASE 1 SPECIFICATION DEVELOPMENT 


\section{RPP-5643 REV 0}

This page intentionally left blank.

A-ii 
RPP-5643 REV 0

\title{
CONTENTS
}

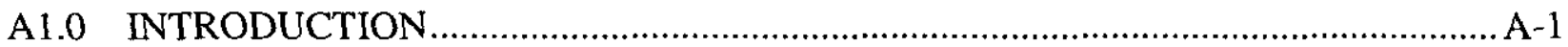

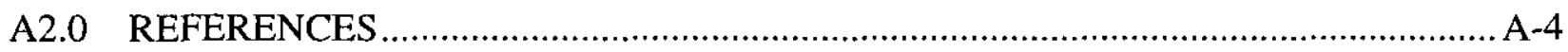

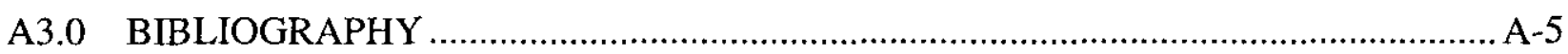

\section{TABLE}

Table A2-1. Phase 1 LAW Feed Tank Contents and Heat Load........................................ A-2 


\section{RPP-5643 REV 0}

\section{LIST OF TERMS}

DST

HMS

LLW

LAW

TSR double-shell tank

Hanford Meteorological Station low-level waste

low activity waste

Technical Safety Requirements 


\section{APPENDIX A \\ TANK SELECTION FOR A PARAMETRIC STUDY TO CHARACTERIZE LOW-LEVEL WASTE TANK HEAT REMOVAL ALTERNATIVES FOR PHASE 1 SPECIFICATION DEVELOPMENT}

\section{A1.0 INTRODUCTION}

This Appendix provides the basis for selecting the tank analyzed by the parametric thermal analyses to quantify heat removal requirements for the low-activity waste (LAW) tanks associated with Phase 1 waste feed delivery. The parametric analysis will determine the maximum ventilation flow required to control waste temperature. This flow will then be included as a performance requirement in the DST Ventilation Subsystem specification. The bounding waste tank will be selected as the worst case Phase 1, waste feed delivery LAW tank. The potential maximum temperature of a tank is a function of both the radioactive decay heat and sludge depth in a tank.

Tables A2-1 list the waste types and volumes in the tanks that are scheduled for retrieval during Phase 1 as documented by the Waste Tank Summary Report (HNF-EP-0182-137) and the Tank Characterization Reports. The Waste Tank Summary Report differentiates between double-shell slurry (DSS) and saltcake; whereas, the Tank Characterization Reports combine them as "double-shell slurry." As used in the Waste Tank Summary Report, DSS is considered to be insoluble and is conducive to the formation of a fluffed (fluffing) solids layer.

The two factors relevant to selecting a tank for this study are the decay heat load and depth of solids after fluffing. The maximum temperature in the solids is directly related to the decay heat load in the solids. For this analysis, it is assumed that all of the decay heat is in the insoluble fraction. The maximum waste temperature also is related directly to the depth of solids. Fluffing increases the heat conduction path length, resulting in higher settled solids temperatures.

For tank selection and this analysis, it was assumed that fluffing will increase the solids depth of DSS by a factor of two, but that saltcake will not fluff. The criterion used to select a bounding tank was the product of the solids depth after fluffing and the heat load. By inspection of the data in Table A2-1, tank 241-AN-103 will have the highest temperatures in the solids. As a result, this tank was selected as the bounding tank for this analysis. 
RPP-5643 REV 0

9

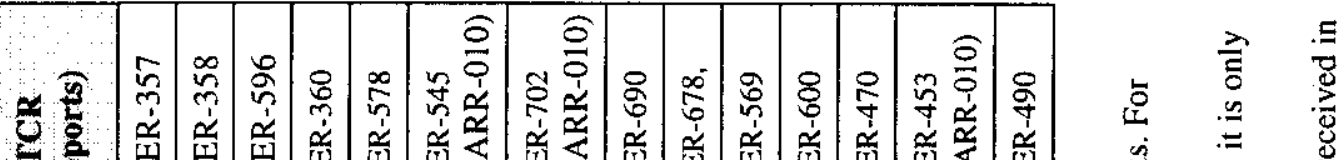

2

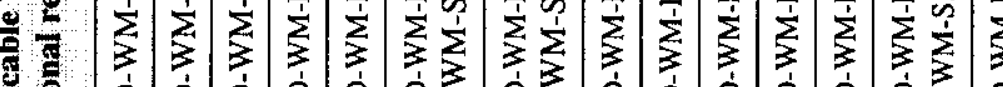

है

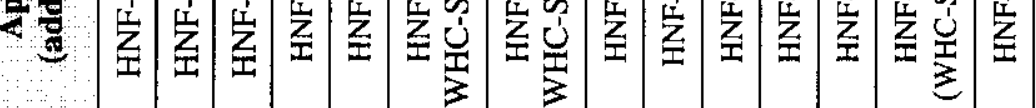

(2)

3

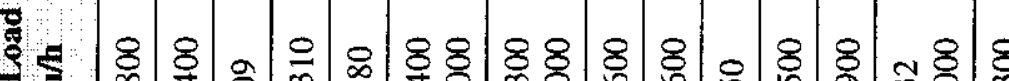

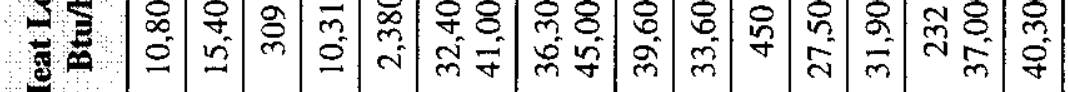

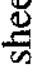

त) है?

ఫ్

胥

宅

E्:

.

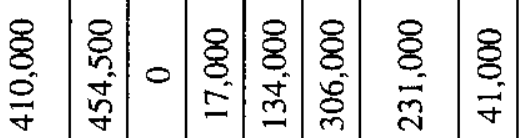

芯 है

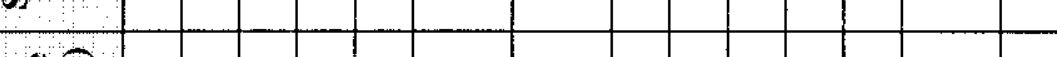

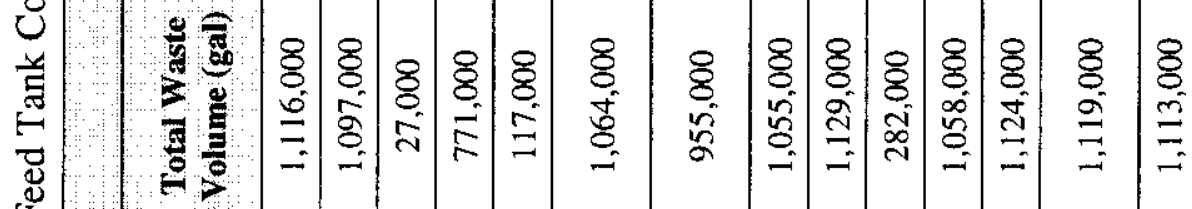

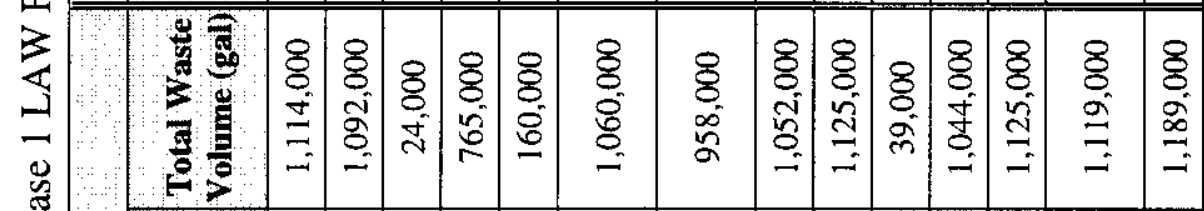

重

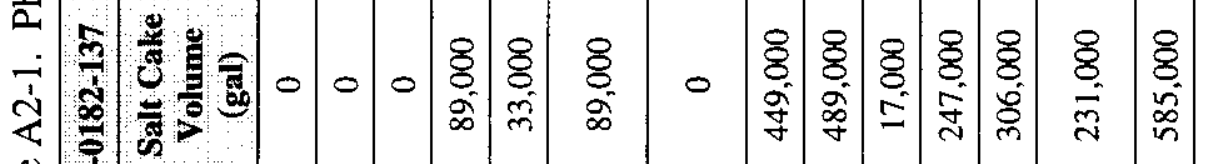

है

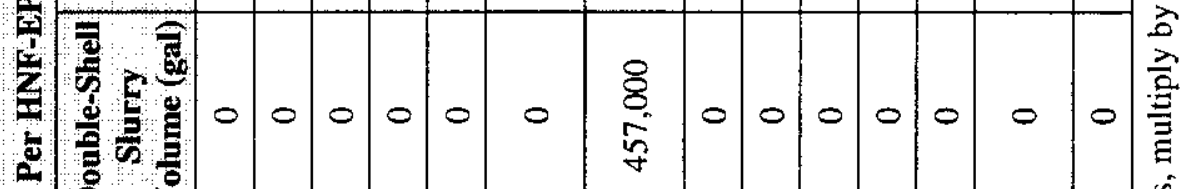

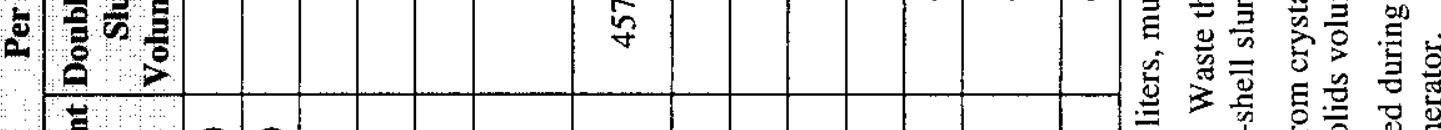

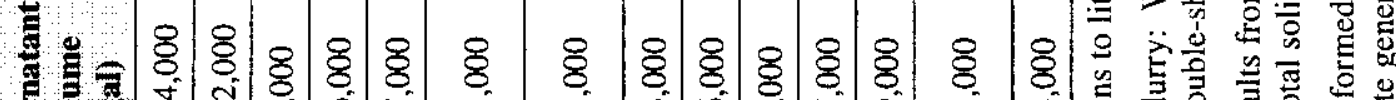

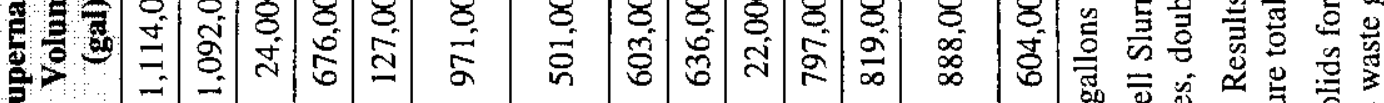

\begin{tabular}{llll} 
& \\
\hline
\end{tabular}

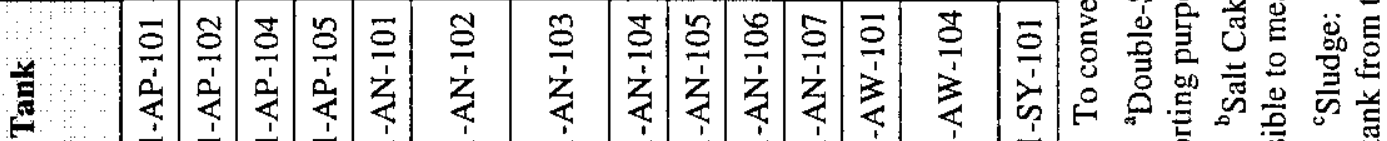

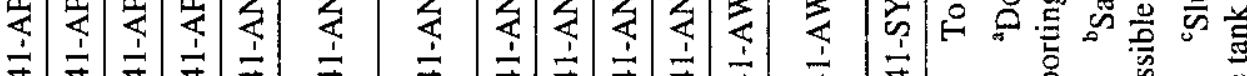
売 


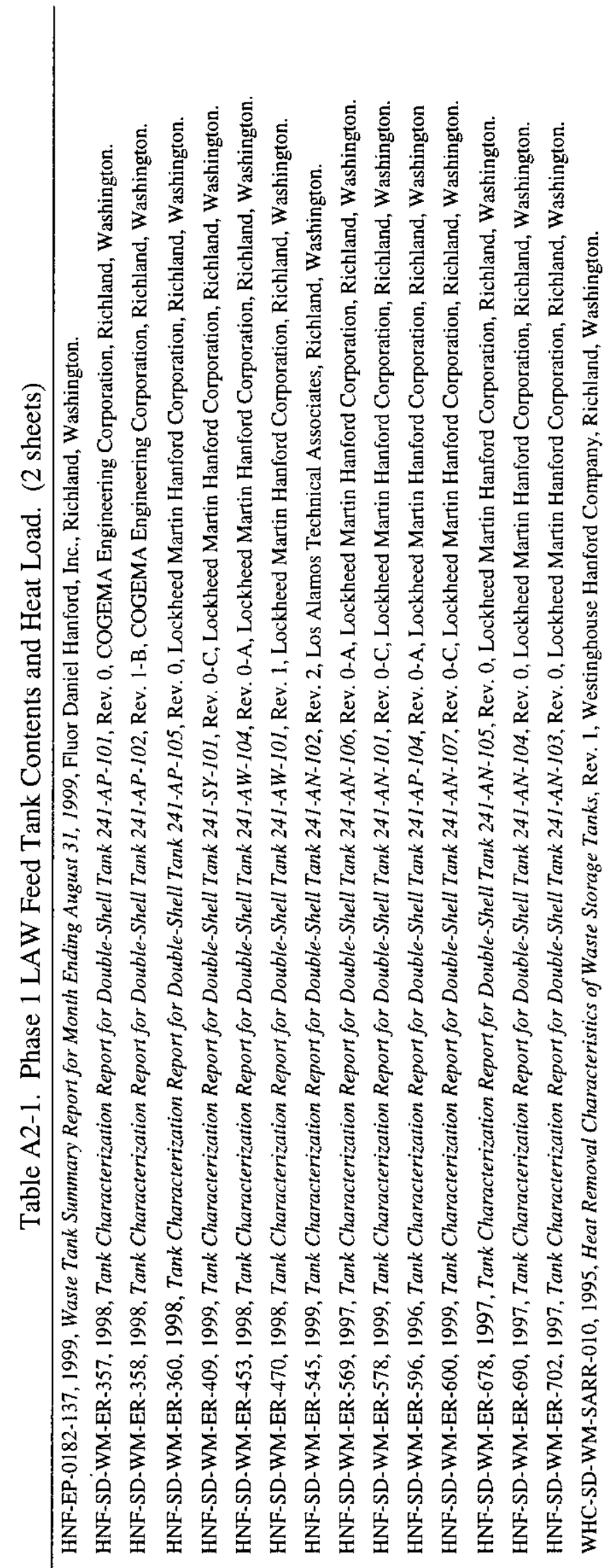




\section{A2.0 REFERENCES}

HNF-5177, 1999, The Settling and Compaction of Nuclear Waste Slurries, Rev. 1, Fluor Daniel Northwest, Richland, Washington.

HNF-5386, 2000, Thermal Hydraulic Analysis of High-Level Waste Tanks for Phase 1 Waste Feed Delivery, Rev. 0, Numatec Hanford Corporation, Richland, Washington.

HNF-EP-0182-137, 1999, Waste Tank Summary Report for Month Ending August 31, 1999, Fluor Daniel Hanford, Inc., Richland, Washington.

HNF-SD-WM-ER-357, 1998, Tank Characterization Report for Double-Shell Tank 241-AP-101, Rev. 0, COGEMA Engineering Corporation, Richland, Washington

HNF-SD-WM-ER-358, 1999, Tank Characterization Report for Double-Shell Tank 241-AP-102, Rev. 1-B, COGEMA Engineering Corporation, Richland, Washington.

HNF-SD-WM-ER-360, 1998, Tank Characterization Report for Double-Shell Tank 241-AP-105, Rev. 1-A, Lockheed Martin Hanford Corporation, Richland, Washington.

HNF-SD-WM-ER-409, 1999, Tank Characterization Report for Double-Shell Tank 241-SY-101, Rev. 0-C, Lockheed Martin Hanford Corporation, Richland, Washington.

HNF-SD-WM-ER-453, 1998, Tank Characterization Report for Double Shell Tank 241-AW-104, Rev. 0-A, Richland, Washington.

HNF-SD-WM-ER-470, 1998, Tank Characterization Report for Double-Shell Tank 241-AW-101, Rev. 1, Lockheed Martin Hanford Corporation, Richland, Washington.

HNF-SD-WM-ER-545, 1999, Tank Characterization Report for Double-Shell Tank 241-AN-102, Rev. 2, Los Alamos Technical Associates, Richland, Washington.

HNF-SD-WM-ER-569, 1997, Tank Characterization Report for Double-Shell Tank 241-AN-106, Rev. 0-A, Lockheed Martin Hanford Corporation, Richland, Washington.

HNF-SD-WM-ER-578, 1999, Tank Characterization Report for Double-Shell Tank 241-AN-101, Rev. 0-C, Lockheed Martin Hanford Corporation, Richland, Washington.

HNF-SD-WM-ER-596, 1996, Tank Characterization Report for Double-Shell Tank 241-AP-104, Rev.0-A, Lockheed Martin Hanford Corporation, Richland, Washington.

HNF-SD-WM-ER-678, 1997, Tank Characterization Report for Double-Shell Tank 241-AN-105, Rev. 0, Lockheed Martin Hanford Corporation, Richland, Washington.

HNF-SD-WM-ER-690, 1997, Tank Characterization Report for Double-Shell Tank 241-AN-104, Rev. 1-A, Lockheed Martin Hanford Corporation, Richland, Washington. 


\section{RPP 5643 REV 0}

HNF-SD-WM-ER-702, 1997, Tank Characterization Report for Double-Shell Tank 241-AN-103, Rev. 0, Lockheed Martin Hanford Corporation, Richland, Washington.

HNF-SD-WM-ER-702, 1998, Tank Characterization Report for Double-Shell Tank 241-AN-103, Rev. 0-B, COGEMA Engineering Corporation, Richland, Washington.

HNF-SD-WM-SAR-067, 1999, Tank Waste Remediation System Final Safety Analysis Report, Rev. 1, Fluor Daniel Hanford, Inc., Richland, Washington.

HNF-SD-WM-TSR-006, 1999, Tank Waste Remediation System Technical Safety Requirements, Rev. 1, Fluor Daniel Hanford, Inc., Richland, Washington.

LA-UR-96-3680, 1997, Hanford Tank Chemical and Radionuclide Inventories: HDW Model, Rev. 4, Los Alamos National Laboratory, Los Alamos, New Mexico.

WHC-SD-WM-ER-198, 1993, Development of A Dynamic Computer Simulator For Aging Waste Tank Operations and Safety Assessment, Rev. 0, Westinghouse Hanford Company, Richland, Washington.

WHC-SD-WM-ER-350, 1995, Historical Tank Content Estimate For Southeast Quadrant of the Hanford 200 Areas, Rev. 0, I.C.F. Kaiser Hanford Company, Richland, Washington.

WHC-SD-WM-ER-410, 1995, Tank Characterization Report for Double-Shell Tank 241-AZ-101, Rev. 0, Westinghouse Hanford Company, Richland, Washington.

WHC-SD-WM-ER-600, 1999, Tank Characterization Report for Double-Shell Tank 241-AN-107, Rev. 0-C, Lockheed Martin Hanford Company, Richland, Washington.

WHC-SD-WM-SARR-010, 1995, Heat Removal Characteristics of Waste Storage Tanks, Rev. 1, Westinghouse Hanford Company, Richland, Washington.

WHC-SD-WM-TI-689, 1996, Waste Status and Transaction Record Summary for the Southeast Quadrant of the Hanford 200 Area, Rev. 1, Westinghouse Hanford Company, Richland, Washington.

\section{A3.0 BIBLIOGRAPHY}

HNF-EP-0182-109, 1997, Waste Tank Summary Report for Month Ending April 30, 1997, Fluor Daniel Hanford, Inc., Richland, Washington

HNF-SD-W320-ER-004, 1998, Project W-320 SAR and Process Control Thermal Analyses, prepared by Numatec Hanford Corporation for Fluor Daniel Hanford, Inc., Richland, Washington. 
RPP 5643 REV 0

This page intentionally left blank.

A-6 
RPP-5643 REV 0

APPENDIX B

MEMORANDUM - "INTERIM GUIDANCE ON LAW RETRIEVAL STRATEGY"

B-i 
RPP-5643 REV 0

This page intentionally left blank.

B-ii 


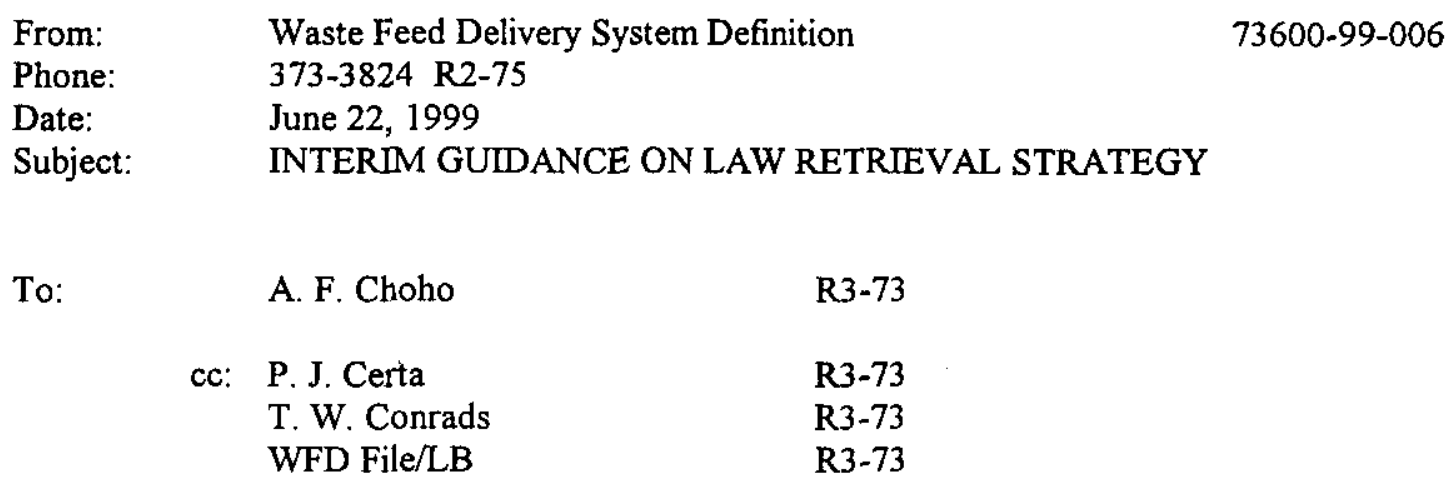

References: (1) HNF-4669, Rev. 0, Decision Document for the Low Activity Waste Retrieval Strategy Decision, dated June 1999.

(2) HNF-4347, Rev. OA, Draft, Alternative Generation Analysis, dated April 29, 1999.

The decision on the LAW retrieval strategy is being developed and is awaiting the results of modeling the likelihood and consequences of degassing the tank waste under several retrieval scenarios. The modeling is due to be completed by the end of July, and a final decision on the strategy is due by the end of August.

Until you receive further instructions from me, please use the attached information as interim guidance for the development of specifications. This guidance results from the decision support board's recommendations on May 7, 1999.

If you have any questions or require additional information, please contact me at 373-3824.

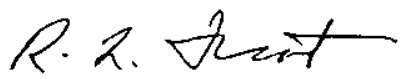

R. L. Treat

Manager

slv

Attachment 


\section{Interim Guidance on the LAW Retrieval Strategy}

\section{$1.0 \quad$ Guidance}

\subsection{Preferred Phase 1 Retrieval Strategy for Low Activity Waste}

Change the current baseline case for the retrieval of low activity waste from tanks AN-103, AN-104, AN-105 and AW-101, and adopt the following sequence:

(1) Install a transfer pump in the supernatant only and remove the existing clarified supernatant without disturbing the underlying settled solids.

(2) Using additional water and tank space created by the removal of the supernatant, install mixer pumps in the tanks and mix the contents, dissolving the soluble salts.

(3) Allow the undissolved solids to settle and then remove the clarified supernatant from the tank.

A schematic of the recommended approach is shown in the attached figure.

\subsection{Accelerate the Schedule for the Initial Retrieval of Supernatant}

Accelerate the schedule for the retrieval of supernatant from tanks AN-104 and/or AN-105 in order to confirm equipment designs early so adjustments can be made if necessary.

\subsection{Additional Guidance}

In implementing the retrieval approach outlined in 1.0 above, include the following guidance:

(1) Flexibility in Dilution During the Removal of the Supernatant

The in-line dilution system should have the capacity to increase the dilution flow rate sufficiently to dissolve entrained solids should a waste rollover occur during the removal of the initial volume of supernatant.

(2) Evaluation of Blending to Bring Out-of-Specification Feed into Specification

Evaluate the potential flexibility provided by blending waste in order to achieve compliance with sulfate specifications for tank AN-104. 
RPP 5643 REV 0

ATTACHMENT

73600-99-006

Page 2 of 4

\subsection{Considerations}

The guidance above is based primarily on the considerations discussed below.

\subsection{Preferred Phase I Retrieval Strategy for Low Activity Waste}

(1) It was assumed that removing the supernatant provides no greater risk of generating a rollover than installation and controlled operation of mixer pumps.

(2) The baseline process strategy is perceived to have a high risk to the construction personnel, if a large waste rollover were to occur during installation of the mixer pumps. The recommended strategy reduces this risk by first installing a small decanting pump and removing the bulk of the supernatant. It is thought that a waste rollover could occur during the removal of the supernatant, if it occurs at all. After the supernatant is removed, then the mixer pumps would be installed.

(3) The baseline process strategy has a high risk of late feed delivery due to slow settling solids after the initial mixing of the tank contents. The recommended strategy reduces this risk by removing the supernatant without mixing and subsequently mixing and dissolving in water added to the tank.

(4) The baseline strategy calls for installation of mixer pumps in the full tanks, some of which have only 10,000 gallons of headspace for additional water addition. The recommended strategy avoids this problem by delaying mixer pump installation until the tank(s) is about half empty. This provides the opportunity to add a considerable quantity of water as needed to install the mixer pumps.

(5) Like the baseline, the recommended strategy leaves most of the undissolved solids in the source tank. This was deemed to be preferable to transferring solids to the staging tank(s), which would then require more frequent cleaning to remove settled solids.

(6) It is possible, perhaps likely, that the initial removal of supernatant will initiate a waste rollover. it is speculated that control of the rate at which the initial volume of supernatant is removed from the tank might reduce the possibility of a rollover and allow progressive gaseous releases.

(7) The recommended strategy includes the flexibility to sample and qualify the dissolved solids feed batch in the source tank. This would reduce the staging tank requirements.

(8) The baseline and the recommended strategy both deliver the initiat supernatant waste separately from the dissolved solids. The chemical 


\section{RPP 5643 REV 0}

ATTACHMENT

73600-99-006

Page 3 of 4

composition of the supernatant and the solids might be sufficiently different that one could be out of specification when a mixture of both would be in specification. This appears to be the case for the dissolved solids batch from tank AN-104.

\subsection{Accelerate the Schedule for the Initial Retrieval of Supernatant}

(1) Accelerating the schedule for retrieval of the initial supernatant provides an early opportunity to observe the waste behavior during the removal of the supernatant and allows for the early installation and operation of mixer pumps to be used to dissolve soluble solids. This early test of the process and equipment will allow time for changes if they are needed before continuous production starts.

(2) Accelerating the schedule for retrieval of the initial supernatant allows the removal of a tank. from flammable gas watch list, if it can be shown that the gas is released during the removal of the supernatant.

(3) Accelerating the schedule for the retrieval of the initial supernatant allows the RPP to demonstrate that successful retrieval has occurred at an early date. 


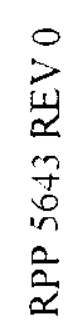

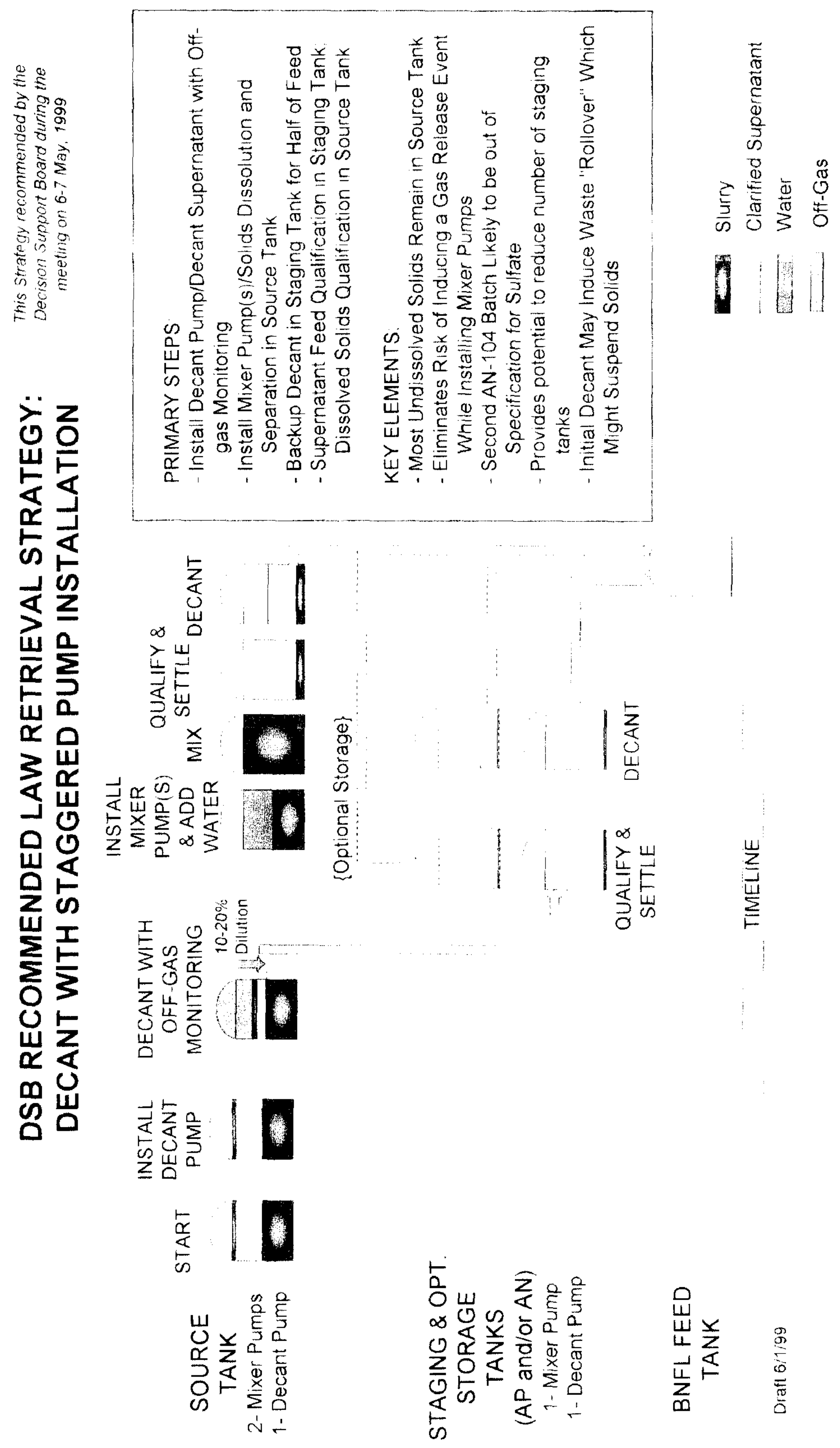


RPP-5643 REV 0

APPENDIX C

PHYSICAL PROPERTIES OF TANK 241-AN-103 WASTE FOR USE IN HEAT REMOVAL ALTERNATIVES STUDY 
RPP-5643 REV 0

This page intentionally left blank.

C-ii 


\section{CORRESPONDENCE DISTRIBUTION COVERSHEET}
Author
Addressee
K. Sathyanarayana, 376-2527
C. E. Grenard, NHC
Correspondence No. FH-0003661

\section{DISTRIBUTION}

\begin{tabular}{lllll}
\hline Approval & Date & Name & Location & w/att \\
\hline Correspondence Control & A3-01 & $X$
\end{tabular}

Fluor Federal Services. Inc.

G. T. MacLean

G3-10

$\mathbf{X}$

Fluor Hanford

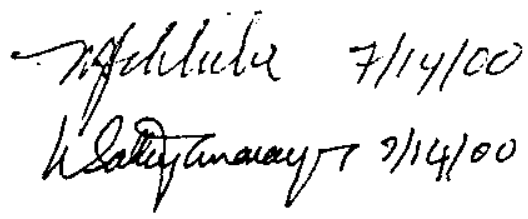

B. A. Crea

R3-86 X

D. P. Fassett

R3-73 X

M. J. Schliebe

L6-13 X

K. Sathyanarayana (2)

L6-35

$X$

Numatec Hanford Compration

T. J. Conrad

R3-73 $\mathrm{X}$ 
Fluor Hanford

P.O. Box 1000

Richland, WA 99352

FLUOR global services

July 14,2000

FH-0003661

Mr. Charles E. Grenard MSIN R3-73

Numatec Hanford Corporation

Post Office Box 1300

Richland, Washington 99352-1300

Dear Mr. Grenard:

\section{PHYSICAL PROPERTIES OF TANK 241-AN-103 WASTE FOR USE IN HEAT REMOVAL ALTERNATIVES STUDY}

This memo is in response to the request for the documentation of the physical parameters used in the thermal analysis for Tank 241-AN-103 Heat Removal Alternatives Study. The physical parameters used are given in Table 1 and 2.

Table 1. Tank 241-AN-103 Waste Properties

\begin{tabular}{|l|c|}
\hline \multicolumn{1}{|c|}{ Waste Property } & Parameter Value \\
\hline Solids Density & $187.2 \mathrm{lbm} / \mathrm{ft}^{3}(3 \mathrm{gm} / \mathrm{cc})$ \\
\hline Liquid Heat Capacity & $0.7643 \mathrm{Btu} / \mathrm{bmm}-{ }^{0} \mathrm{R}(3.2 \mathrm{~kJ} / \mathrm{kg}-\mathrm{K})$ \\
\hline Solids Heat Capacity & $0.20 \mathrm{Btu} / \mathrm{bm}-{ }^{0} \mathrm{R}\left(0.84 \mathrm{~kJ} / \mathrm{kg}-{ }^{0} \mathrm{~K}\right)$ \\
\hline Thermal Conductivity of Aqueous Solution & $90 \%$ of the value of water \\
\hline Thermal Conductivity of Solids & $5.0 \mathrm{Btu} / \mathrm{hr}-\mathrm{th}-\mathrm{R}\left(8.65 \mathrm{~W} / \mathrm{m}-{ }^{-} \mathrm{K}\right)$ \\
\hline Total Heat Generation Rate in the Waste & $36,300 \mathrm{Btu} / \mathrm{hr}(10.64 \mathrm{~kW})$ \\
\hline
\end{tabular}

Table 2. Undiluted and Diluted Waste Parameters

\begin{tabular}{|l|c|c|}
\hline \multicolumn{1}{|c|}{ Waste Property } & Undiluted Waste & Diluted Waste \\
\hline Fluffed Sludge Height & $24.8 \mathrm{ft}(7.56 \mathrm{~m})$ & $1.46 \mathrm{ft}(0.445 \mathrm{~m})$ \\
\hline Volume Fraction of Solids & 0.163 & 0.10 \\
\hline Liquid Vapor Pressure & $31 \%$ of the value of water & $60 \%$ of the value of water \\
\hline
\end{tabular}


July 14,2000

Page 2

\section{Solids Density}

The density of waste solids was estimated from various ESP simulations. Additional ESP simulations were performed and the density values derived are tabulated below corresponding to the average waste temperature. (See Attachment 1)

\begin{tabular}{|c|c|c|}
\hline Waste Temperature, $^{\circ} \mathrm{F}$ & Solids Density, $\mathrm{gm} / \mathrm{cc}$ & Liquid Density, $\mathrm{gm} / \mathrm{cc}$ \\
\hline 104 & 2.82 & 1.38 \\
\hline 140 & 3.48 & 1.35 \\
\hline 176 & 3.5 & 1.33 \\
\hline 212 & 3.45 & 1.32 \\
\hline 248 & 3.2 & 1.39 \\
\hline
\end{tabular}

The solids density of $3 \mathrm{gm} / \mathrm{cc}$ was selected at the time based on earlier calculations performed at 104 and $195^{\circ} \mathrm{F}$. Based on the results of those two calculations, it was assumed that solids density of $3 \mathrm{gm} / \mathrm{cc}$ is more reasonable. However, the recent ESP calculations show that a solids density of $3.5 \mathrm{gm} / \mathrm{cc}$ is more appropriate. Since for thermal analysis calculations, the total waste heat load and the nonconvective waste (sludge) volume were defined independently and are not based on solids density, the results and therefore, the conclusions will not be affected by this value. The solids density parameter in GOTH calculations will become important for calculating the settling time. The settling time, however, is defined independently for these analyses and so the value has no effect on the thermal analysis results.

\section{Liquid Specific Heat}

Specific Heats of Solutions in the System $\mathrm{NaNO}_{3}-\mathrm{H}_{2} \mathrm{O}$

\begin{tabular}{|c|c|c|c|}
\hline & \multicolumn{3}{|c|}{$\mathrm{NaNO}_{3}$ Solution Concentration (wt\%) } \\
\hline & 20.12 & 30.19 & 40.19 \\
\hline Temperature & $\begin{array}{c}\mathrm{C}_{\mathrm{p}} \\
\text { Btu//mb-F }\end{array}$ & $\begin{array}{c}\mathrm{C}_{\mathrm{p}} \\
\mathrm{Btu} / \mathrm{lmb}-\mathrm{F}\end{array}$ & $\frac{\mathrm{C}_{\mathrm{p}}}{\mathrm{Btu} / \mathrm{lmb}-\mathrm{F}}$ \\
\hline 77 & 0.837 & 0.777 & 0.714 \\
\hline 122 & 0.839 & 0.775 & 0.712 \\
\hline 167 & 0.840 & 0.774 & 0.711 \\
\hline 212 & 0.840 & 0.774 & 0.710 \\
\hline
\end{tabular}

The liquid specific heat for $30 \mathrm{wt}$. \% sodium nitrate is 0.77 (Btu/lbm- $\left.{ }^{\circ} \mathrm{F}\right)(3.22 \mathrm{KJ} / \mathrm{Kg}-\mathrm{K})$. 
Reference: Puchkov, Matveeva, and Baranova, "Specific Heats of Aqueous Solutions of Sodium and Potassium Nitrates at Temperatures in the Range $25-340^{\circ} \mathrm{C}$, "Zhurnal Prikladnoi Khimii, Vol. 46, No.2, pp.443-445.(Translated Feb 1973)

\section{Solids Specific Heat}

A value of $0.2 \mathrm{Btu} / \mathrm{lbm}-{ }^{0} \mathrm{~F}$ was used for the solids in the waste. For solids representing minerals and impervious rocks, the heat capacity is given by the formula:

$$
\mathrm{Cp}=0.55 / \text { Specific Gravity }=0.18 \cong 0.2
$$

Using a solids specific gravity of $3 \mathrm{gm} / \mathrm{cc}$, it is approximately equal to $0.2 \mathrm{Btu} / \mathrm{bm}-{ }^{\circ} \mathrm{F}$.

Reference: Touloukian, Y. S., W. R. Judd and R. F. Roy, "CINDAS Data Series on Material Properties," Vol. 11-2, 1981, page 413, McGraw-Hill Co.

\section{Thermal Conductivity of Aqueous Solution}

The mixture thermal conductivity for dilute solutions usually decreases with an increase in the concentration of the dissolved salts. The mixture conductivity has been estimated using the formula given Perry's Chemical Engineer's Handbook. For details of the calculation see Attachment 2. The thermal conductivity of the aqueous phase in AN-103 is $90 \%$ of that of water.

Reference: Perry, R. H., D. W. Green and J. O. Maloney, Perry's Chemical Engineers Handbook, $6^{\text {th }}$ Edition, 1984, Page 3-285.

\section{Thermal Conductivity of solids}

The solids in the tank were treated as containing only a single component whose thermal conductivity has been assumed as $5 \mathrm{Btu} / \mathrm{hr}-\mathrm{ft}-\mathrm{R}$. This is supported by the values of thermal conductivity for minerals and ceramics. The thermal conductivity of some solid salts (CRC Handbook P. E-4) such as Sodium Chloride and Potassium Chloride are about $5.3 \mathrm{Btu} / \mathrm{hr}-\mathrm{ft}-$ R. Also for series thermal conductivity model used in GOTH calculations, the effect of solids thermal conductivity on the mixture thermal conductivity is negligible (For explanation see Reference 1, Section 4.2.5 and Figure 4.1) because the volume fraction of solids in the sludge (slurry) is less than $20 \%$.

Reference: 1. Sathyanarayana, K., 2000,"Thermal Analysis of High Level Waste Tanks for Phase 1 Waste Feed Delivery," HNF-5386, Fluor Hanford Inc., Richland, Washington. 
2. CRC, 1975 , CRC Handbook of Chemistry and Physics, $56^{\text {th }}$ Edition, CRC Press, Inc., Cleveland, Ohio

6. Heat Generation Rate

The total heat generation rate in the tank waste is $36,300 \mathrm{Btu} / \mathrm{hr}$ as per the Tank Waste Characterization Report.

Reference: Kupfer, M.J., 1998, "Tank Characterization Report for Double -Shell Tank 241AN-103," HNF-SD-WM-ER-702, Rev. 0-B, COGEMA Engineering Corp., Richland, Washington.

\section{Fluffed Sludge Height}

a) Undiluted Waste

The double shell sludge volume as per the characterization report and shown in Table A2-2 of RPP-5643 is 410,000 gallons. Based on this volume and assuming the fluffing factor of 2, the fluffed sludge height is estimated to be $24.8 \mathrm{ft}$. (See Attachment 3, Page 3 of 3, Eqn. 6.21.)

b) Diluted Waste

The following parameters are used to calculate the fluffed sludge height for diluted waste.

Solids density $=3 \mathrm{gm} / \mathrm{cc}$

Liquid density $=1.33 \mathrm{gm} / \mathrm{cc}$

Insoluble solids in the mixed waste $=0.5$ volume $\%$ or $\sim 1 \%$ by weight

Total Waste Volume $=958,000$ gallons as per Hanlon's report (see Table A2-1 of RPP-5643) Assuming that final compacted non-convective waste (sludge) will have $40 \mathrm{wt} \%$ solids and the fluffed waste will have $20 \mathrm{wt} \%$ solids. Using these waste parameters the height of the initial non-convective waste is estimated to be $1.46 \mathrm{ft}$. (See Attachment 3 for details)

8. Volume Fraction of Solids

a) Undiluted Waste

The following parameters (TCR Report of Kupfer) were used to estimate the volume fraction of solids in the undiluted waste. (See Attachment 4) 
Sludge bulk density $=1.62 \mathrm{gm} / \mathrm{cc}$

Weight $\%$ of water in slurry $=31.8$

Supernatant density $=1.46 \mathrm{gm} / \mathrm{cc}$

Weight $\%$ of water in Supernatant $=51.1$

Using these waste parameters, the density of solids and the volume fraction of solids in the undisturbed current sludge were estimated to be $1.95 \mathrm{gm} / \mathrm{cc}$ and 0.326 . For the fluffed sludge, the volume fraction of solids is assumed to be 0.163 .

\section{b) Diluted Sludge}

As explained for sludge height calculation, the solids volume fraction of the fluffed sludge is estimated to be about 0.1 .

\section{Supernatant Liquid Vapor Pressure}

\section{a) Undiluted Waste}

The vapor pressure of liquid is calculated using the value of water activity from ESP simulation. For undiluted AN-103 waste, the liquid vapor pressure is $31 \%$ of that for water at the corresponding temperature. The vapor pressure of liquid is estimated using the ESP calculated vapor composition. (See Attachment 5)

b) Diluted Waste

The water activity from ESP simulation for diluted AN-103 waste is 0.6 . The vapor pressure of the liquid is therefore $60 \%$ of that for water. (See Attachment 1 for ESP results)

Sincerely,

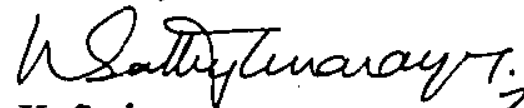

K. Sathyanarayana $j / 14 / 2000$

Process Engineering and Modeling

Fluor Hanford Inc.

KS: sj

Attachments (5) 


\section{RPP 5643 REV 0}

\section{ATTACHMENT 1}

\section{ESP RESULTS}

FOR DILUTED TANK 241-AN-103 WASTE STREAM
a) WASTE STREAM TEMPERATURE $40^{\circ} \mathrm{C}\left(104^{\circ} \mathrm{F}\right)$
b) WASTE STREAM TEMPERATURE $60^{\circ} \mathrm{C}\left(140^{\circ} \mathrm{F}\right)$
c) WASTE STREAM TEMPERATURE $80^{\circ} \mathrm{C}\left(176^{\circ} \mathrm{F}\right)$
d) WASTE STREAM TEMPERATURE $100^{\circ} \mathrm{C}\left(212^{\circ} \mathrm{F}\right)$
e) WASTE STREAM TEMPERATURE $120 \mathrm{C}\left(248^{\circ} \mathrm{F}\right)$
f) Undiluted AN-103 Waste Stream at $41{ }^{\circ} \mathrm{C}\left(106^{\circ} \mathrm{F}\right)$ 
Fluor Federal Services

1200 Jadwin. PO Box 1050

Richland. WA 9935?-1050

$5093 \div 2-2000$ phone

$5093 \div 2-3000$ fax

July 3,2000

FLUOR GLOBAL SERVICES

Dr. K. Sathyanarayana

Fluor Hanford

P.O. Box 1000, MSIN L6-35

Richland, Washington 99352-1000

Dear Dr. Sathyanarayana:

PHYSICAL PROPERTIES OF TANK AN-103 WASTE FOR USE IN COMPUTATIONAL FLUID DYNAMICS SIMULATIONS

The physical property values supplied for use in Computational Fluid Dynamics simulations of mixing diluted Tank AN-103 waste were obtained as follows:

Solid Phase Density $=3 \frac{\mathrm{kg}}{\mathrm{L}}$, the average density of tank waste sludge solids estimated from various ESP simulations and hand calculations.

Solid Phase Heat Capacity $=\frac{.55}{S . G .} \cong .2 \frac{B T U}{16^{\circ} \mathrm{F}}$

Reference: formula for heat capacity of ninerals and impervious rocks in "CNNDAS Data Series on Material Properties," Y.S. Touloukian, W.R. Judd, R.F. Roy, Vol. 112, 1981, p.413, McGraw-Hill.

Solid Phase Thermal Conductivity $=5 \frac{B T U}{\mathrm{hr} \cdot \mathrm{ft} \cdot{ }^{\circ} \mathrm{F}}$

Reference: gross average of values for minerals and ceramics in various handbooks. Experimental data is very limited, so the value is only approximate.

Solution Density $=1.33 \frac{\mathrm{kg}}{\mathrm{L}}$, average of ESP survey values for diluted AN-103 sludge from $60-80^{\circ} \mathrm{C}$ (see attached). 


\section{Fluor Federal Services}

Dr. K. Sathyanarayana

July 3,2000

Fluor Hanford

Page 2 of 2

Richland, WA 99352

Solution Heat Capacity $=.77 \frac{B T U}{1 b^{\circ} \mathrm{F}}$

Reference: average value for $30 \mathrm{wt} . \%$ sodium nitrate in "Specific Heats of Aqueous Solutions of Sodium and Potassium Nitrates at Temperatures in the Range $25-340^{\circ} \mathrm{C}$," Puchkov, Matveeva, and Baranova, Zhurnal Prikladnoi Khimii, Vol. 46, No.2, pp. 443-445, translated to English Feb. 1973

Solution Thermal Conductivity $=.35 \frac{\mathrm{BTU}}{\mathrm{hr} \cdot \mathrm{ft} \cdot{ }^{\circ} \mathrm{F}}$

Reference: average of values for $20-30 \mathrm{wt} . \%$ sodium nitrate and nitrite in "Handbook of Physical Properties of Liquids and Gases," N.B. Vargaftik, $2^{\text {nd }}$ ed., 1975, Hemisphere Publishing Corporation, p. 685.

Insoluble Solids Mass Concentration $=1.0 \mathrm{wt} . \%$, approximate value from ESP survey for diluted $\mathrm{AN}-103$ sludge from $60-100^{\circ} \mathrm{C}$ (see attached).

Insoluble Solids Volume Concentration $=\frac{C_{m}}{C_{m}+r\left(100-C_{m}\right)}=.5$ vol. $\%$, in which $C_{m}=$ wt.\% insoluble solids, $\mathrm{r}=$ ratio of solids density to solution density.

Water vapor partial pressure $=60 \%$ of pure water vapor pressure at the same temperature, since the water activity calculated with ESP (see attached survey) is about .6 from $40-100^{\circ} \mathrm{C}$.

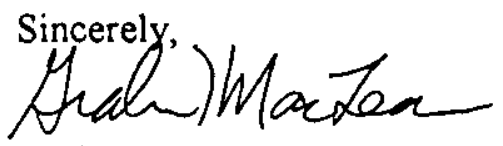

Graham T. MacLean

Principal Process Engineer

GTM:mb

Attachment 


\title{
RPP 5643 REV 0
}

\begin{tabular}{|c|c|c|c|c|}
\hline 0 & 0 & 0 & L & $I I I I$ \\
\hline 0 & & 0 & L & $I$ \\
\hline 0 & & 0 & I & $I$ \\
\hline b & & 0 & L & I \\
\hline b & & 0 & I & $I$ \\
\hline 0 & & 0 & L & I \\
\hline 0 & & 0 & L & $I$ \\
\hline 0 & & 0 & $L$ & $I$ \\
\hline 0 & 0 & 0 & $L I L L I L I L$ & $I I I I$ \\
\hline
\end{tabular}

ENVIRONMENTAL SIMULATION PROGRAM

\author{
$V-6.3$ December 1,1999 \\ SURVEY: DILUTED SLUDGE \\ CHEMISTRY MODEL: AN103 \\ THIS FILE NAME: DILUTEDS.LIS \\ DATE: $01 / 11 / 2000$
}

TABLE OF CONTENTS

STREAM SECTION

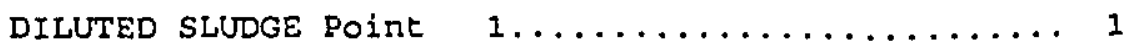

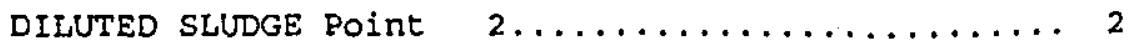

DILUTED SLUDGE Point $3 \ldots \ldots \ldots \ldots \ldots \ldots \ldots \ldots \ldots$

DILUTED SLUDGE Point $4 \ldots \ldots \ldots \ldots \ldots \ldots \ldots \ldots \ldots$

DILUTED SLUDGE Point $5 \ldots \ldots \ldots \ldots \ldots \ldots \ldots \ldots \ldots$ 


\section{RPP 5643 REV 0}

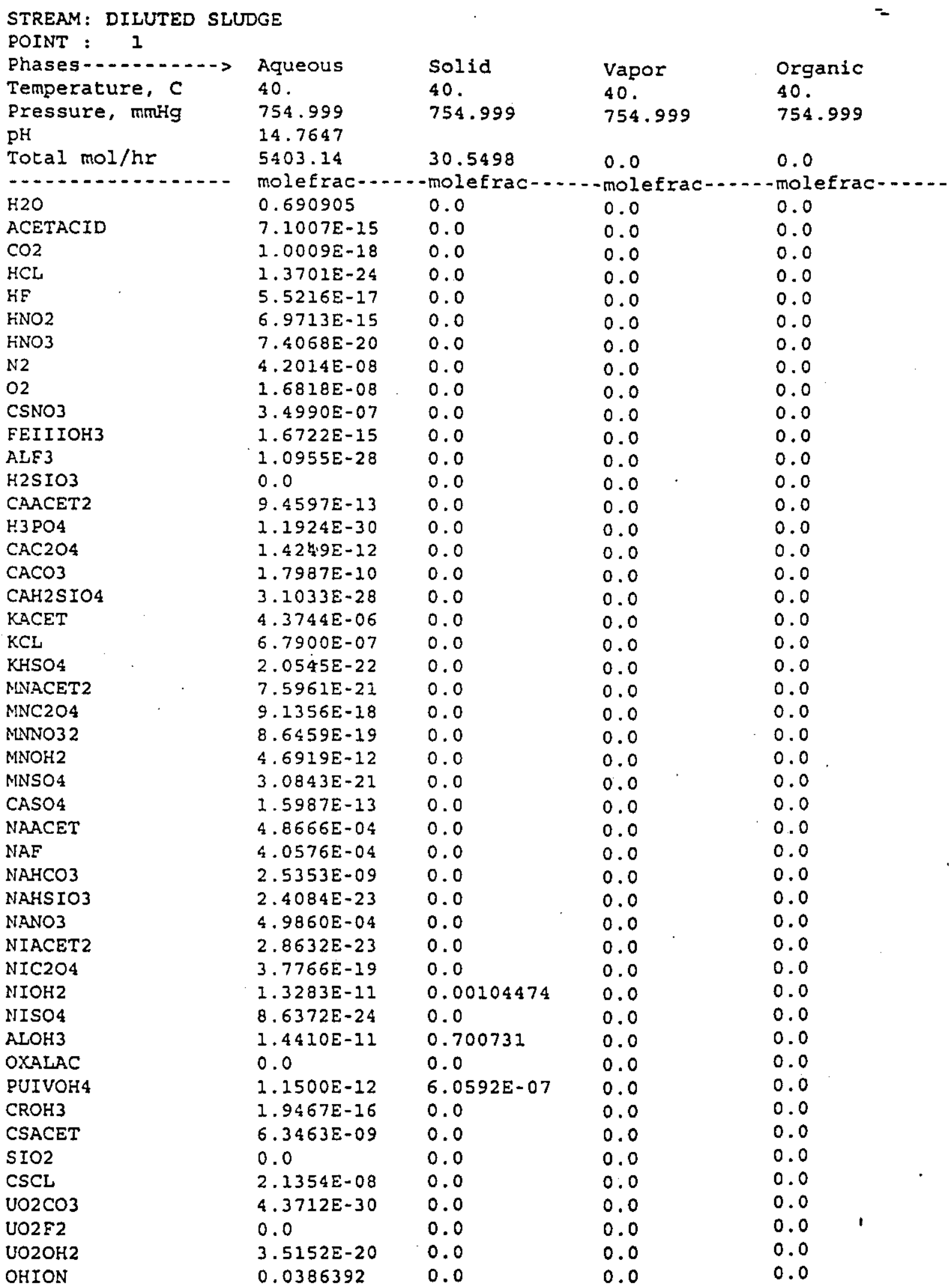


RPP 5643 REV 0

\begin{tabular}{|c|c|c|c|c|}
\hline ALF2 ION & $2.5200 E-30$ & 0.0 & 0.0 & 0.0 \\
\hline ALF 4 ION & $1.0521 E-26$ & 0.0 & 0.0 & 0.0 \\
\hline ALESION & $1.0512 \mathrm{E}-25$ & 0.0 & 0.0 & 0.0 \\
\hline ALFGION & $8.9562 \mathrm{E}-25$ & 0.0 & 0.0 & 0.0 \\
\hline ALOH2 ION & $1.5632 \mathrm{E}-20$ & 0.0 & 0.0 & 0.0 \\
\hline ALOH 4 ION & 0.0234582 & 0.0 & 0.0 & 0.0 \\
\hline ALOHION & $1.1138 \mathrm{E}-30$ & 0.0 & 0.0 & 0.0 \\
\hline CAACETION & $2.2643 E-11$ & 0.0 & 0.0 & 0.0 \\
\hline CAFION & $4.4105 E-13$ & 0.0 & 0.0 & 0.0 \\
\hline CAH 2 POA ION & $6.7846 E-24$ & 0.0 & 0.0 & 0.0 \\
\hline CAHC2O4ION & $9.2582 \mathrm{E}-24$ & 0.0 & 0.0 & 0.0 \\
\hline CALCO3ION & $2.1585 E-16$ & 0.0 & 0.0 & 0.0 \\
\hline CAION & $8.6756 \mathrm{E}-10$ & 0.0 & 0.0 & 0.0 \\
\hline CANO3ION & $6.0375 E-18$ & 0.0 & 0.0 & 0.0 \\
\hline CAOHION & $8.0308 E-09$ & 0.0 & 0.0 & 0.0 \\
\hline CAPOAION & $1.7419 \mathrm{E}-08$ & 0.0 & 0.0 & 0.0 \\
\hline CLION & 0.00178763 & 0.0 & 0.0 & 0.0 \\
\hline CO3ION & 0.00428797 & 0.0 & 0.0 & 0.0 \\
\hline CR207ION & $1.7037 \mathrm{E}-24$ & 0.0 & 0.0 & 0.0 \\
\hline CRO4 ION & $1.0267 \mathrm{E}-05$ & 0.0 & 0.0 & 0.0 \\
\hline CR.OH2 ION & $7.9310 E-25$ & 0.0 & 0.0 & 0.0 \\
\hline CPOH 4 ION & $2.2821 E-11$ & 0.0 & 0.0 & 0.0 \\
\hline CROHION & 0.0 & 0.0 & 0.0 & 0.0 \\
\hline CSION & $7.0489 \mathrm{E}-11$ & 0.0 & 0.0 & 0.0 \\
\hline CSSO4ION & $1.3943 E-09$ & 0.0 & 0.0 & 0.0 \\
\hline FEIIIOH 2 ION & $1.9227 \mathrm{E}-24$ & 0.0 & 0.0 & 0.0 \\
\hline FEI I IOH 4 ION & $7.5807 E-09$ & 0.0 & 0.0 & 0.0 \\
\hline FION & $4.3636 \mathrm{E}-04$ & 0.0 & 0.0 & 0.0 \\
\hline H2 PO4 ION & $1.3171 \mathrm{E}-16$ & 0.0 & 0.0 & 0.0 \\
\hline H.SSIO4ION & $4.9610 E-30$ & 0.0 & 0.0 & 0.0 \\
\hline H3SIO4ION & $9.7753 E-26$ & 0.0 & 0.0 & 0.0 \\
\hline HCO3ION & $4.9398 \mathrm{E}-09$ & 0.0 & 0.0 & 0.0 \\
\hline HCROA ION & $2.1335 \mathrm{E}-15$ & 0.0 & 0.0 & 0.0 \\
\hline HEZION & $4.5055 \varepsilon-18$ & 0.0 & 0.0 & 0.0 \\
\hline HION & $1.0288 E-17$ & 0.0 & 0.0 & 0.0 \\
\hline HOXALATION & $1.31778-17$ & 0.0 & 0.0 & 0.0 \\
\hline HP2O7ION & $1.7606 \mathrm{E}-24$ & 0.0 & 0.0 & 0.0 \\
\hline HPO4 ION & $1.3238 E-07$ & 0.0 & 0.0 & 0.0 \\
\hline HSIO3ION & 0.0 & 0.0 & 0.0 & 0.0 \\
\hline HSO4ION & $2.5246 E-19$ & 0.0 & 0.0 & 0.0 \\
\hline KION & 0.00246038 & 0.0 & 0.0 & 0.0 \\
\hline KSO4 ION & $3.9997 E-06$ & 0.0 & 0.0 & 0.0 \\
\hline MNACET 3 ION & $5.7500 E-21$ & 0.0 & 0.0 & 0.0 \\
\hline MNACETION & $4.1652 E-19$ & 0.0 & 0.0 & 0.0 \\
\hline MNC2O42ION & $3.4456 \mathrm{E}-20$ & 0.0 & 0.0 & 0.0 \\
\hline MNC2043 ION & $7.5754 \mathrm{E}-19$ & 0.0 & 0.0 & 0.0 \\
\hline MNCLION & $9.4049 \varepsilon-19$ & 0.0 & 0.0 & 0.0 \\
\hline MNION & $7.2369 E-17$ & 0.0 & 0.0 & 0.0 \\
\hline MNNO3ION & $1.4215 E-18$ & 0.0 & 0.0 & 0.0 \\
\hline MNOH 3 ION & $1.4369 E-08$ & 0.0 & 0.0 & 0.0 \\
\hline MNOH 4 ION & $5.1608 E-06$ & 0.0 & 0.0 & 0.0 \\
\hline MNOHION & $3.4602 E-14$ & 0.0 & 0.0 & 0.0 \\
\hline NA2FION & $9.9681 E-12$ & 0.0 & 0.0 & 0.0 \\
\hline NACO3ION & 0.00134883 & 0.0 & 0.0 & 0.0 \\
\hline NAION & 0.153958 & 0.0 & 0.0 & 0.0 \\
\hline
\end{tabular}


RPP 5643 REV 0

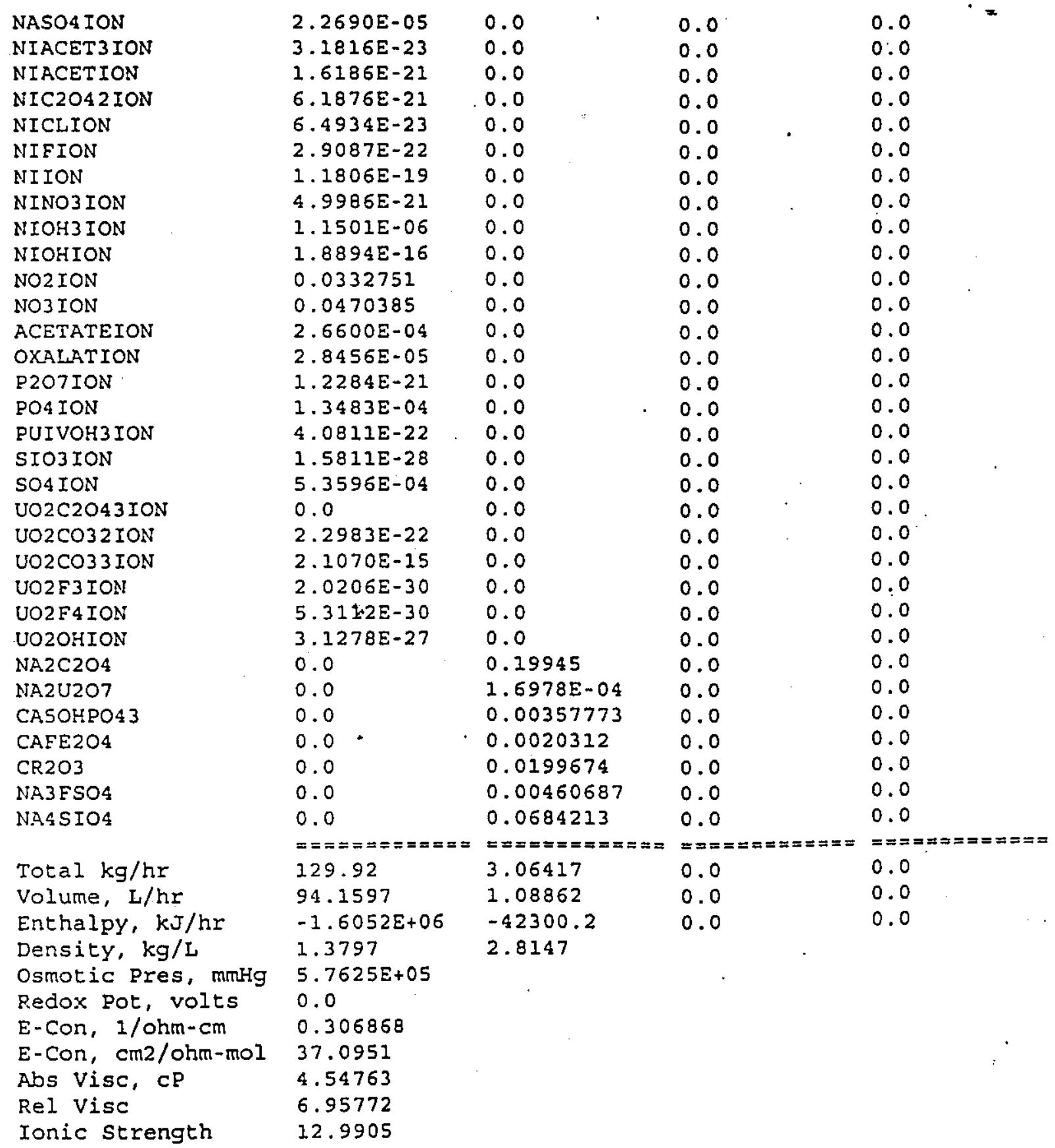




\section{RPP 5643 REV 0}

STREAM: DILUTED SLIUDGE

\begin{tabular}{|c|c|c|c|c|}
\hline Phases-l- & Aqueous & Solid & Vapor & organic \\
\hline Temperature, C & 60 & 60 & 60. & 60 \\
\hline Pressure, mmig & 754.999 & 754.999 & 754.999 & 754.999 \\
\hline $\mathrm{pH}$ & 14.0733 & & & \\
\hline Total mol/hr & $\begin{array}{l}5406.38 \\
\text { molefrac-. }\end{array}$ & $\begin{array}{l}8.90589 \\
\text { molefrac... }\end{array}$ & $\begin{array}{l}0.0 \\
\text {-molefrac }\end{array}$ & $\begin{array}{l}0.0 \\
- \text { molefrac. }\end{array}$ \\
\hline $\mathrm{H} 2 \mathrm{O}$ & 0.69049 & 0.0 & 0.0 & 0.0 \\
\hline ACETACID & $3.8420 E-14$ & 0.0 & 0.0 & 0.0 \\
\hline $\mathrm{CO} 2$ & $2.0680 E-17$ & 0.0 & 0.0 & 0.0 \\
\hline $\mathrm{H} 2 \mathrm{~F} 2$ & 0.0 & 0.0 & 0.0 & 0.0 \\
\hline ACET 2 & 0.0 & 0.0 & 0.0 & 0.0 \\
\hline $\mathrm{HCL}$ & $2.1344 \mathrm{E}-23$ & 0.0 & 0.0 & 0.0 \\
\hline $\mathrm{HF}$ & $3.8169 \mathrm{E}-16$ & 0.0 & 0.0 & 0.0 \\
\hline $\mathrm{HNO} 2$ & $2.5970 E-14$ & 0.0 & 0.0 & 0.0 \\
\hline HNO3 & $9.6111 \mathrm{E}-19$ & 0.0 & 0.0 & 0.0 \\
\hline $\mathrm{N} 2$ & $4.1989 \mathrm{E}-08$ & 0.0 & 0.0 & 0.0 \\
\hline 02 & $1.6808 \mathrm{E}-08$ & 0.0 & 0.0 & 0.0 \\
\hline CSNO3 & $3.4879 E-07$ & 0.0 & 0.0 & 0.0 \\
\hline FEIIIOH 3 & $9.6229 E-15$ & 0.0 & 0.0 & 0.0 \\
\hline ALF3 & $2.5655 \mathrm{E}-27$ & 0.0 & 0.0 & 0.0 \\
\hline $\mathrm{H} 2 \mathrm{SIO} 3$ & $9.6591 E-30$ & 0.0 & 0.0 & 0.0 \\
\hline CAACET2 & $5.8849 E-13$ & 0.0 & 0.0 & 0.0 \\
\hline H3PO4 & $1.7988 E-28$ & 0.0 & 0.0 & 0.0 \\
\hline $\mathrm{CAC} 2 \mathrm{O} 4$ & $3.7570 E-12$ & 0.0 & 0.0 & 0.0 \\
\hline $\mathrm{CACO} 3$ & $1.7462 \mathrm{E}-10$ & 0.0 & 0.0 & 0.0 \\
\hline CAH2SIO4 & $1.0457 \mathrm{E}-27$ & 0.0 & 0.0 & 0.0 \\
\hline KACET & $5.4565 \mathrm{E}-06$ & 0.0 & 0.0 & 0.0 \\
\hline KCL & $1.0178 E-06$ & 0.0 & 0.0 & 0.0 \\
\hline KHSO 4 & $1.8482 E-21$ & 0.0 & 0.0 & 0.0 \\
\hline MNACET2 & $5.9861 E-20$ & 0.0 & 0.0 & 0.0 \\
\hline MNC2O4 & $1.3661 E-16$ & 0.0 & 0.0 & 0.0 \\
\hline $\mathrm{MNNO} 32$ & $8.1333 E-18$ & 0.0 & 0.0 & 0.0 \\
\hline MNOH2 & $1.6722 E-11$ & 0.0 & 0.0 & 0.0 \\
\hline MNSOG & $2.0984 E-20$ & 0.0 & 0.0 & 0.0 \\
\hline CASO 4 & $7.2154 \mathrm{E}-14$ & 0.0 & 0.0 & 0.0 \\
\hline NAACET & $4.7805 E-04$ & 0.0 & 0.0 & 0.0 \\
\hline NAF & $3.8880 E-04$ & 0.0 & 0.0 & 0.0 \\
\hline $\mathrm{NAHCO} 3$ & $1.6189 E-08$ & 0.0 & 0.0 & 0.0 \\
\hline NAHSIO3 & $2.2324 \mathrm{E}-22$ & 0.0 & 0.0 & 0.0 \\
\hline NANO3 & $4.4098 \mathrm{E}-04$ & 0.0 & 0.0 & 0.0 \\
\hline NIACET 2 & $7.5379 E-23$ & 0.0 & 0.0 & 0.0 \\
\hline $\mathrm{NIC2O4}$ & $2.5967 \mathrm{E}-18$ & 0.0 & 0.0 & 0.0 \\
\hline NIOH2 & $1.2646 \mathrm{E}-11$ & 0.00407073 & 0.0 & 0.0. \\
\hline NISO4 & $3.2267 E-23$ & 0.0 & 0.0 & 0.0 \\
\hline ALOH 3 & $3.7636 E-11$ & 0.0 & 0.0 & 0.0 \\
\hline OXAIAC & $1.1722 \mathrm{E}-29$ & 0.0 & 0.0 & 0.0 \\
\hline PUIVOH4 & $3.0070 \mathrm{E}-22$ & $2.0774 \mathrm{E}-06$ & 0.0 & 0.0 \\
\hline CROH3 & $3.3532 \mathrm{E}-16$ & 0.0 & 0.0 & 0.0 \\
\hline CSACET & $6.4845 E-09$ & 0.0 & 0.0 & 0.0 \\
\hline SIO2 & $2.7641 E-29$ & 0.0 & 0.0 & 0.0 \\
\hline CSCL & $2.2576 E-08$ & 0.0 & 0.0 & 0.0 \\
\hline $\mathrm{UO} 2 \mathrm{CO} 3$ & $1.6681 \mathrm{E}-28$ & 0.0 & 0.0 & 0.0 \\
\hline $\mathrm{UO} 2 \mathrm{~F} 2$ & 0.0 & 0.0 & 0.0 & 0.0 \\
\hline
\end{tabular}




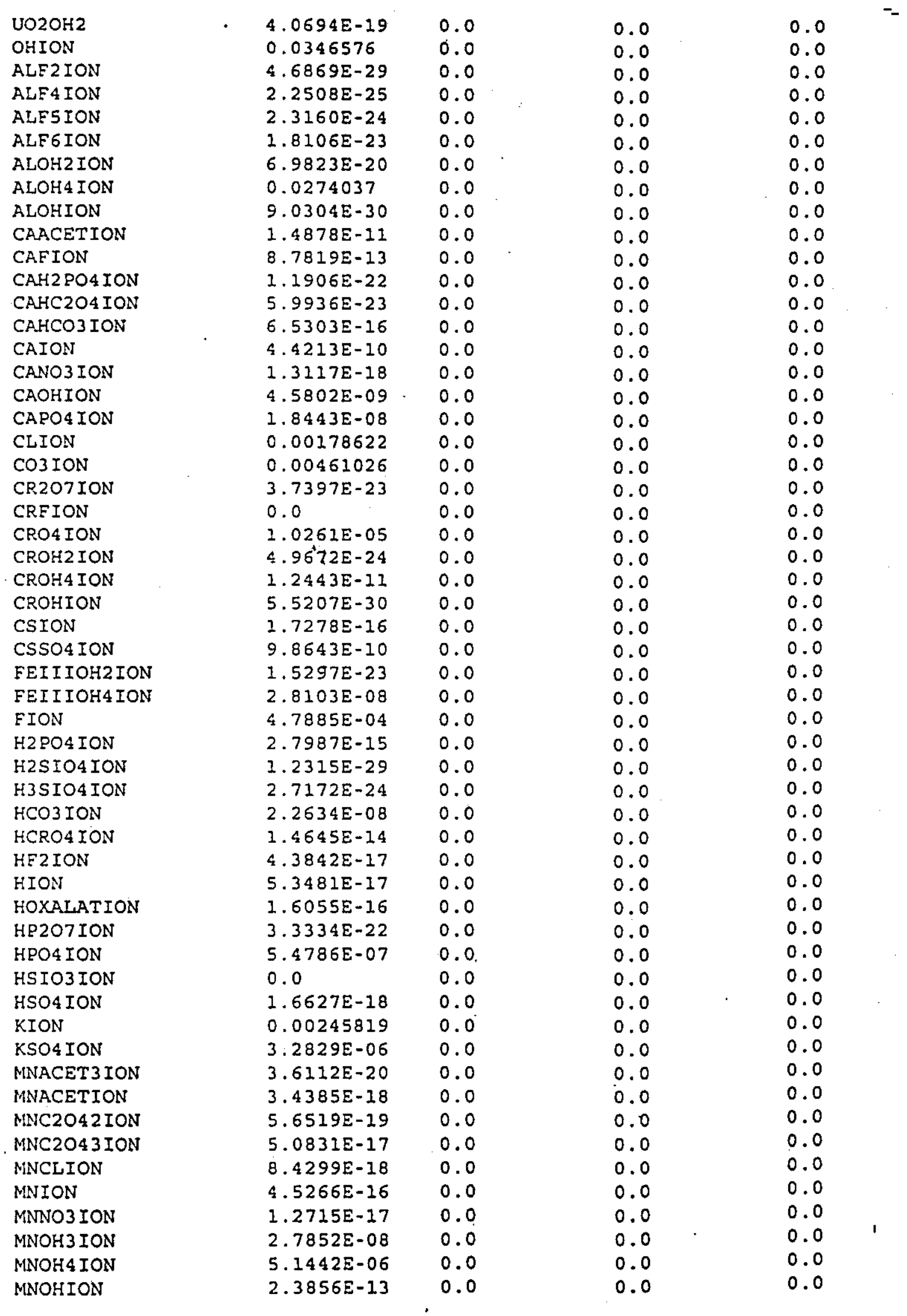


RPP 5643 REV 0

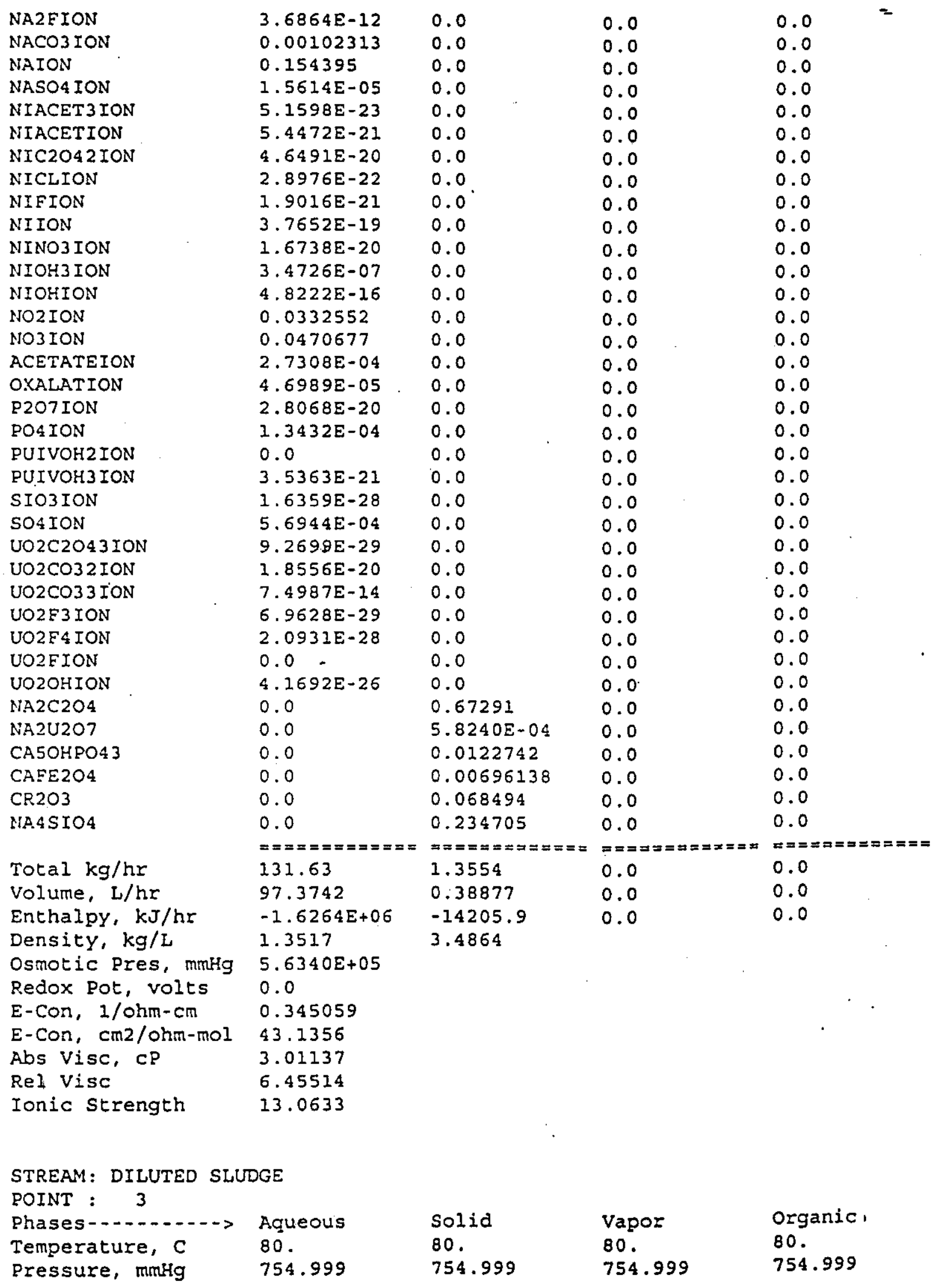


RPP 5643 REV 0

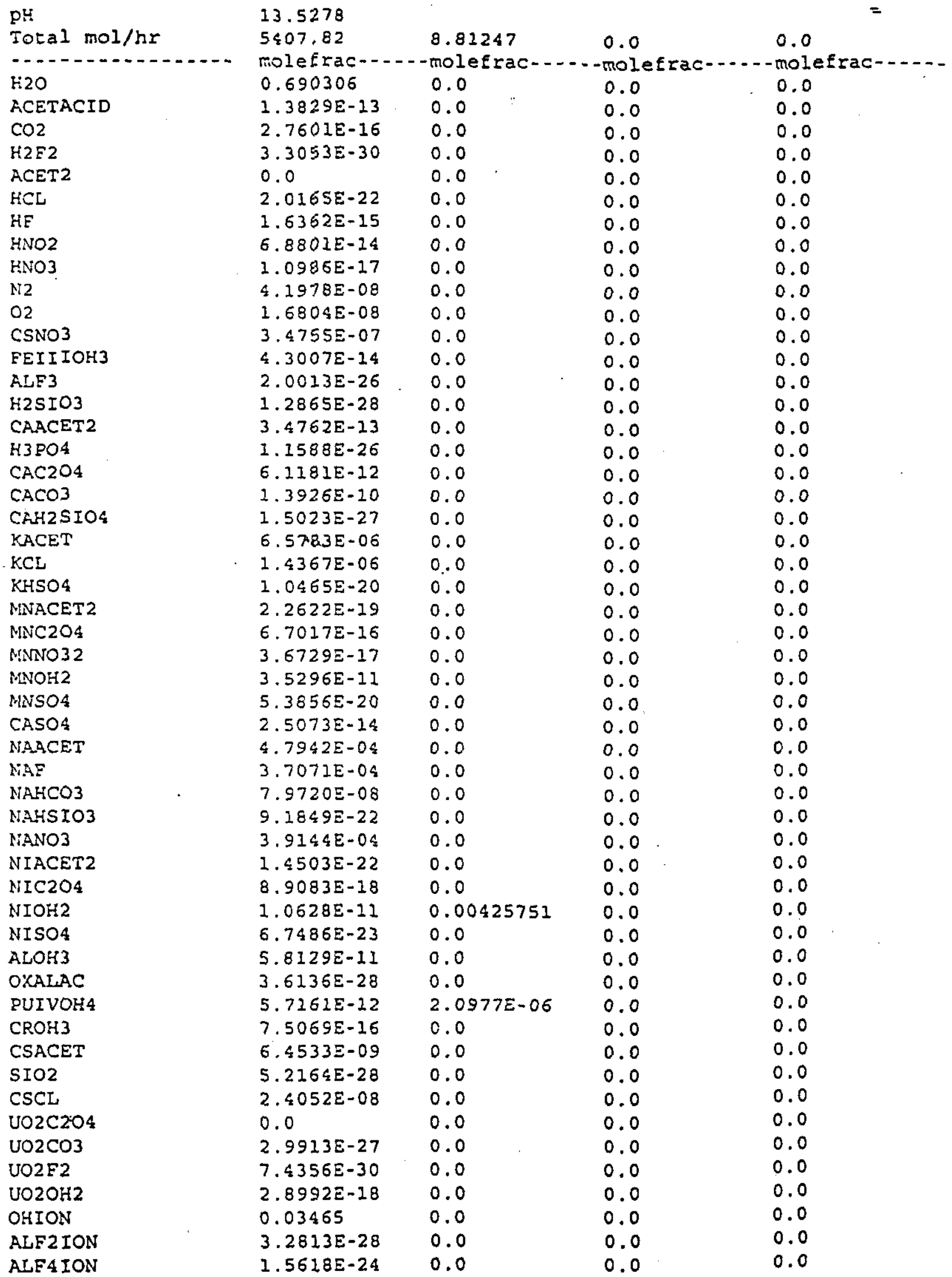


RPP 5643 REV 0

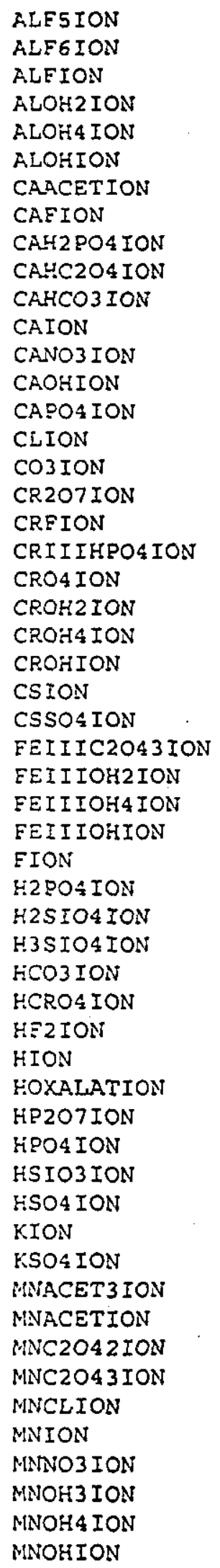

\begin{tabular}{|c|c|}
\hline $1.4620 E-23$ & 0.0 \\
\hline $9.0618 \Xi-23$ & 0.0 \\
\hline 0.0 & 0.0 \\
\hline $1.6695 \mathrm{E}-19$ & 0.0 \\
\hline 0.0273964 & 0.0 \\
\hline $3.3537 E-29$ & 0.0 \\
\hline $8.6582 E-12$ & 0.0 \\
\hline $1.2793 E-12$ & 0.0 \\
\hline $1.1884 E-21$ & 0.0 \\
\hline $2.0826 E-22$ & 0.0 \\
\hline $1.3990 E-15$ & 0.0 \\
\hline $1.9400 E-10$ & 0.0 \\
\hline $1.7651 E-19$ & 0.0 \\
\hline $2.5649 \mathrm{E}-09$ & 0.0 \\
\hline $1.7503 E-08$ & 0.0 \\
\hline 0.00178533 & 0.0 \\
\hline 0.00475031 & 0.0 \\
\hline $5.1175 E-22$ & 0.0 \\
\hline $5.6243 E-30$ & 0.0 \\
\hline $4.5974 \mathrm{E}-30$ & 0.0 \\
\hline $1.0258 \mathrm{E}-05$ & 0.0 \\
\hline $3.2982 E-23$ & 0.0 \\
\hline $9.3886 \varepsilon-12$ & 0.0 \\
\hline $7.3498 \mathrm{E}-29$ & 0.0 \\
\hline $5.3788 E-24$ & 0.0 \\
\hline $6.7714 \mathrm{E}-10$ & 0.0 \\
\hline 0.0 & 0.0 \\
\hline $6.1352 E-23$ & 0.0 \\
\hline $7.9873 E-08$ & 0.0 \\
\hline 0.0 & 0.0 \\
\hline $4.9671 E-04$ & 0.0 \\
\hline $3.76395-14$ & 0.0 \\
\hline $1.0652 E-29$ & 0.0 \\
\hline $2.8411 E-23$ & 0.0 \\
\hline $8.0469 E-08$ & 0.0 \\
\hline $7.9267 E-14$ & 0.0 \\
\hline $3.3141 \varepsilon-16$ & 0.0 \\
\hline $2.0621 E-16$ & 0.0 \\
\hline $1.2532 E-15$ & 0.0 \\
\hline $3.1707 E-20$ & 0.0 \\
\hline $1.8418 E-06$ & 0.0 \\
\hline 0.0 & 0.0 \\
\hline $7.1345 E-18$ & 0.0 \\
\hline 0.0024557 & 0.0 \\
\hline $2.5725 E-06$ & 0.0 \\
\hline $1.3238 \Xi-19$ & 0.0 \\
\hline $1.25958-17$ & 0.0 \\
\hline $3.0354 \mathrm{E}-18$ & 0.0 \\
\hline $9.6377 \mathrm{E}-16$ & 0.0 \\
\hline $3.3287 \mathrm{E}-17$ & 0.0 \\
\hline $1.35055-15$ & 0.0 \\
\hline $5.1048 E-17$ & 0.0 \\
\hline $4.1665 \mathrm{E}-08$ & 0.0 \\
\hline $5.1290 \mathrm{E}-06$ & 0.0 \\
\hline $7.9750 E-13$ & 0.0 \\
\hline
\end{tabular}

0.0

0.0

0.0

0.0

0.0

0.0

0.0

0.0

0.0

0.0

0.0

0.0

0.0

0.0

0.0

0.0

0.0

0.0

0.0

0.0

0.0

0.0

0.0

0.0

0.0

0.0

0.0

0.0

0.0

0.0

0.0

0.0

0.0

0.0

0.0

0.0

0.0

0.0

0.0

0.0

0.0

0.0

0.0

0.0

0.0

0.0

0.0

0.0

0.0

0.0

0.0

0.0

0.0

0.0

0.0
0.0

0.0

0.0

0.0

0.0

0.0

0.0

0.0

0.0

0.0

0.0

0.0

0.0

0.0

0.0

0.0

0.0

0.0

0.0

0.0

0.0

0.0

0.0

0.0

0.0

0.0

0.0

0.0

0.0

0.0

0.0

0.0

0.0

0.0

0.0

0.0

0.0

0.0

0.0

0.0

0.0

0.0

0.0

0.0

0.0

0.0

0.0

0.0

0.0

0.0

0.0

0.0

0.0

0.0

0.0 


\section{RPP 5643 REV 0}

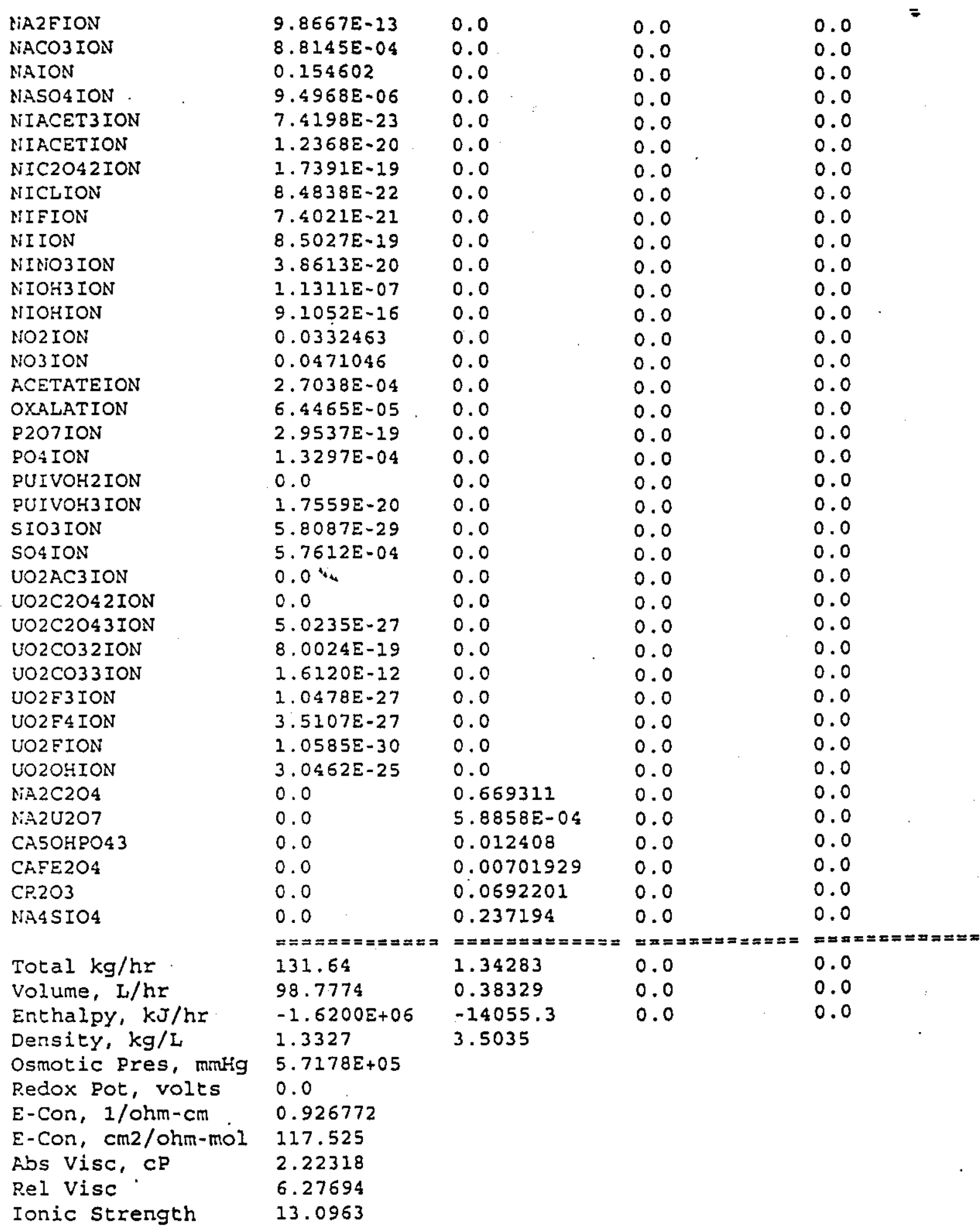


RPP 5643 REV 0

STREAM: DILUTED SLUDGE

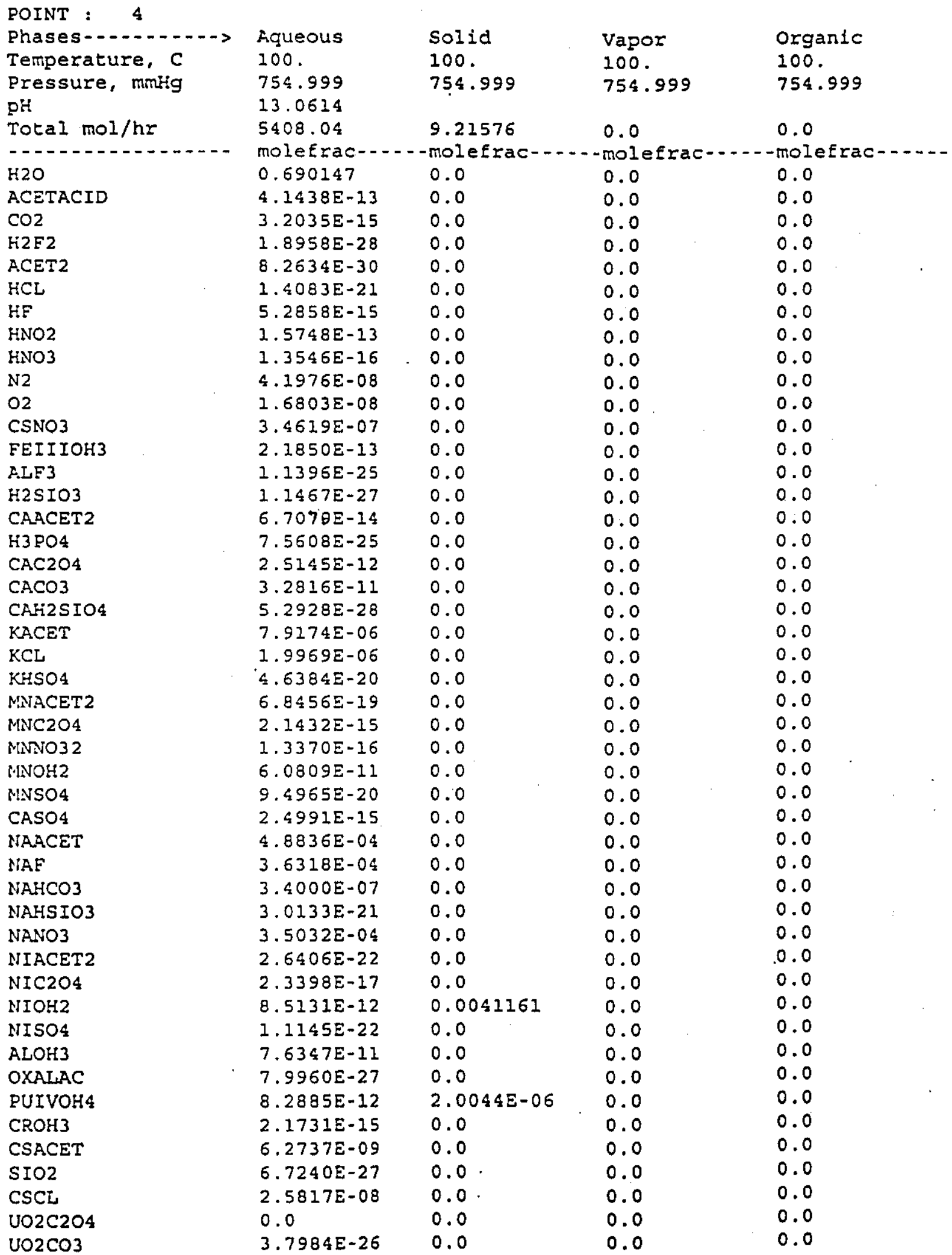


RPP 5643 REV 0

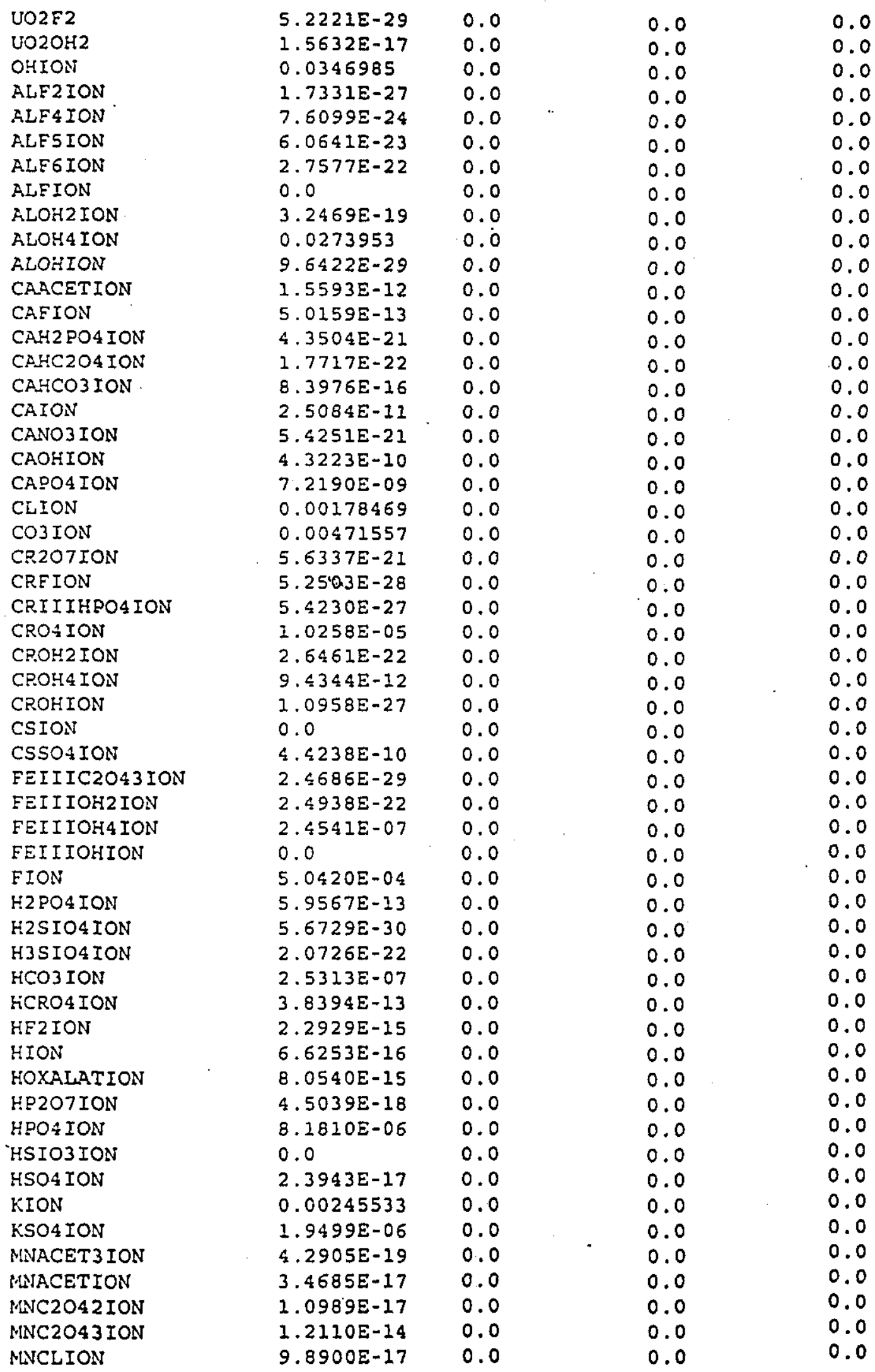


RPP 5643 REV 0

\begin{tabular}{|c|c|c|c|c|c|}
\hline MNION & $2.8845 E-15$ & 0.0 & 0.0 & 0.0 & $=$ \\
\hline MNNO3ION & 1. $5581 E-16$ & 0.0 & 0.0 & 0.0 & \\
\hline MNOH 3 ION & $5.5082 E-08$ & 0.0 & 0.0 & 0.0 & \\
\hline MNOSEION & $5.1153 E-06$ & 0.0 & 0.0 & 0.0 & \\
\hline MSOHION & $1.9498 E-12$ & 0.0 & 0.0 & 0.0 & \\
\hline NA2FION & $1.9685 E-13$ & 0.0 & 0.0 & 0.0 & \\
\hline NACO3 ION & $8.02988-04$ & 0.0 . & 0.0 & 0.0 & \\
\hline NAION & 0.154754 & 0.0 & 0.0 & 0.0 & \\
\hline NASOGION & $5.0965 E-06$ & 0.0 & 0.0 & 0.0 & \\
\hline NIACET3ION & $1.1154 E-22$ & 0.0 & 0.0 & 0.0 & \\
\hline NIACETION & $2.4823 E-20$ & 0.0 & 0.0 & 0.0 & \\
\hline NIC2O42ION & $5.1497 \mathrm{E}-19$ & 0.0 & 0.0 & 0.0 & \\
\hline NICLION & $2.1589 E-21$ & 0.0 & 0.0 & 0.0 & \\
\hline NIFION & $2.3686 \varepsilon-20$ & 0.0 & 0.0 & 0.0 & \\
\hline NIION & $1.6071 \mathrm{E}-18$ & 0.0 & 0.0 & 0.0 & \\
\hline NINO3ION & $8.0255 E-20$ & 0.0 & 0.0 & 0.0 & \\
\hline NIOH 3 ION & $3.6600 E-08$ & 0.0 & 0.0 & 0.0 & \\
\hline NIOHION & $1.5116 E-15$ & 0.0 & 0.0 & 0.0 & \\
\hline NO2 ION & 0.033245 & 0.0 & 0.0 & 0.0 & \\
\hline NO3ION & 0.0471437 & 0.0 & 0.0 & 0.0 & \\
\hline ACETATEION & $2.6008 \mathrm{E}-04$ & 0.0 & 0.0 & 0.0 & \\
\hline OXALATION & $8.2210 E-05$ & 0.0 & 0.0 & 0.0 & \\
\hline 9207ION & $4.2205 E-18$ & 0.0 & 0.0 & 0.0 & \\
\hline PO4ION & $1.87305-04$ & 0.0 & 0.0 & 0.0 & \\
\hline PUIVOH2ION & $1.7308 E-30$ & 0.0 & 0.0 & 0.0 & $\cdot$ \\
\hline PUIVOS3ION & $6.0845 E-20$ & 0.0 & 0.0 & 0.0 & \\
\hline SIO3ION & $1.2551 E-29$ & 0.0 & 0.0 & 0.0 & \\
\hline SO 4 ION & $5.8111 E-04$ & 0.0 & 0.0 & 0.0 & \\
\hline UO2AC3ION & 0.0 & 0.0 & 0.0 & 0.0 & \\
\hline UO2ACION & 0.0 & 0.0 & 0.0 & 0.0 & \\
\hline UO2C2042ION & 0.0 & 0.0 & 0.0 & 0.0 & \\
\hline UO2C2O43ION & $1.7945 E-25$ & 0.0 & 0.0 & 0.0 & \\
\hline UO2CO32ION & $2.50735-17$ & 0.0 & 0.0 & 0.0 & \\
\hline $\mathrm{LO} 2 \mathrm{CO} 33 \mathrm{ION}$ & $2.94055-11$ & 0.0 & 0.0 & 0.0 & \\
\hline UO2F3ION & $1.1143 E-26$ & 0.0 & 0.0 & 0.0 & \\
\hline UO2F 4 ION & $\leq .1817 E-26$ & 0.0 & 0.0 & 0.0 & \\
\hline UO2FION & $5.6244 E-30$ & 0.0 & 0.0 & 0.0 & \\
\hline UO2OHION & $1.6933 \mathrm{E}-24$ & 0.0 & 0.0 & 0.0 & \\
\hline $\mathrm{NA} 2 \mathrm{C} 2 \mathrm{O4}$ & 0.0 & 0.629606 & 0.0 & 0.0 & \\
\hline $\mathrm{NA} 2 \mathrm{U} 207$ & 0.0 & $5.6281 E-04$ & 0.0 & 0.0 & \\
\hline $\mathrm{CR} 2 \mathrm{O} 3$ & 0.0 & 0.066191 & 0.0 & 0.0 & \\
\hline FEIII203 & 0.0 & 0.00666354 & 0.0 & 0.0 & \\
\hline NACSIO4 & 0.0 & 0.226814 & 0.0 & 0.0 & \\
\hline \multirow[t]{2}{*}{$\mathrm{CACO} 3 . \mathrm{H} 2 \mathrm{O}$} & 0.0 & 0.0660445 & 0.0 & 0.0 & \\
\hline & 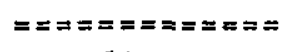 & 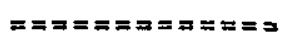 & 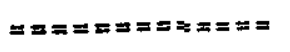 & $z==z$ & $=\approx=\approx==3$ \\
\hline Total kg/hr & 131.64 & 1.34342 & 0.0 & 0.0 & \\
\hline Volume, I/hr & 99.5813 & 0.38897 & 0.0 & 0.0 & \\
\hline Enthalpy, kJ/hr & $-1.6134 \mathrm{E}+06$ & -14039 & 0.0 & 0.0 & \\
\hline Density, $\mathrm{kg} / \mathrm{L}$ & 1.3219 & 3.4538 & & & \\
\hline Osmotic Pres, mmig & $5.8323 E+05$ & & & & \\
\hline E-Con, 1/ohm-cm & 1.01124 & & & & \\
\hline E-Con, $\operatorname{cm} 2 /$ ohm-mol & 129.279 & & & & \\
\hline Abs Visc, cP & 1.83791 & & & & \\
\hline Rel Visc & 6.52719 & & & & \\
\hline Ionic strength & 13.1241 & & & & \\
\hline
\end{tabular}




\section{RPP 5643 REV 0}

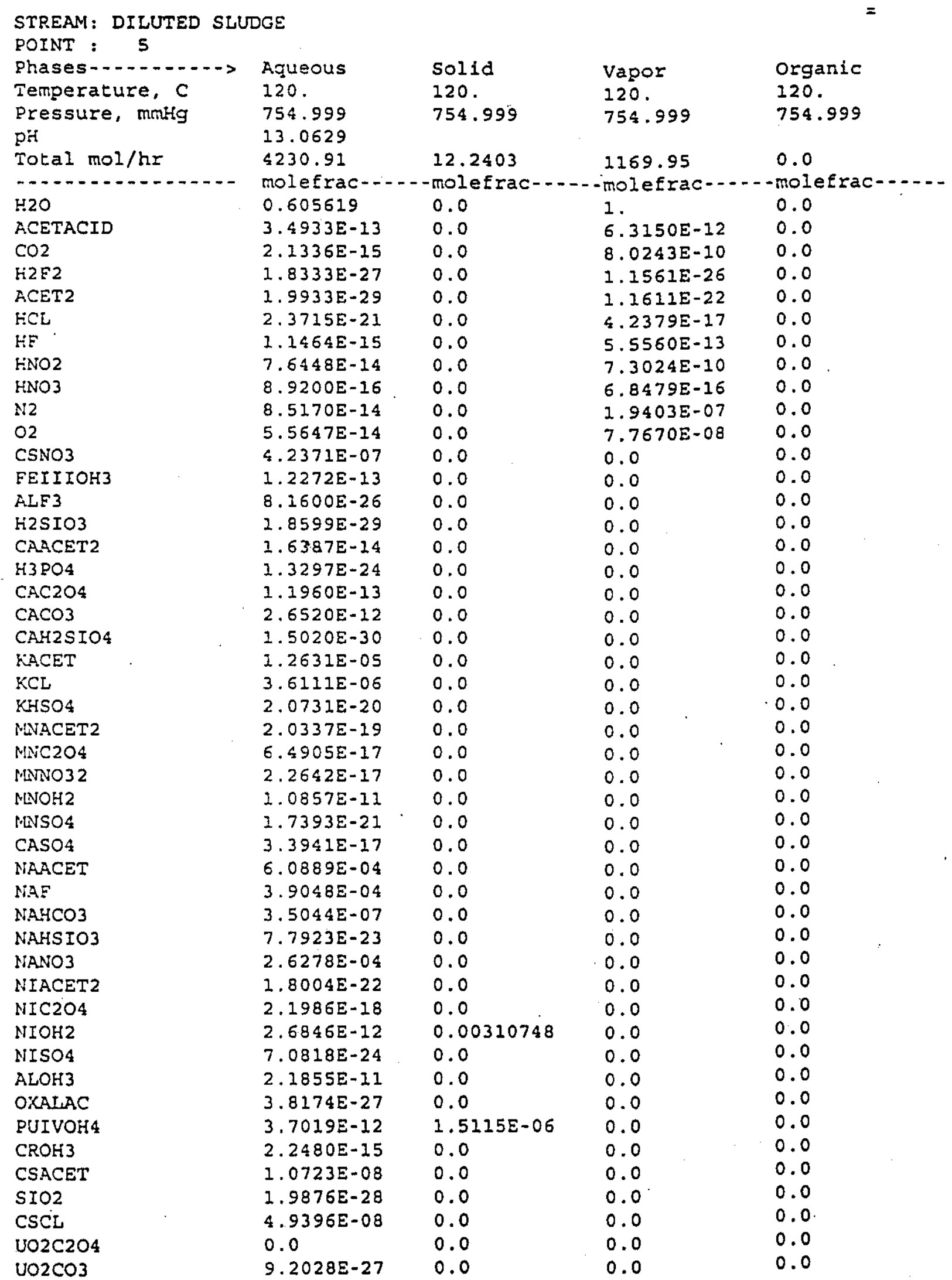


RPP 5643 REV 0

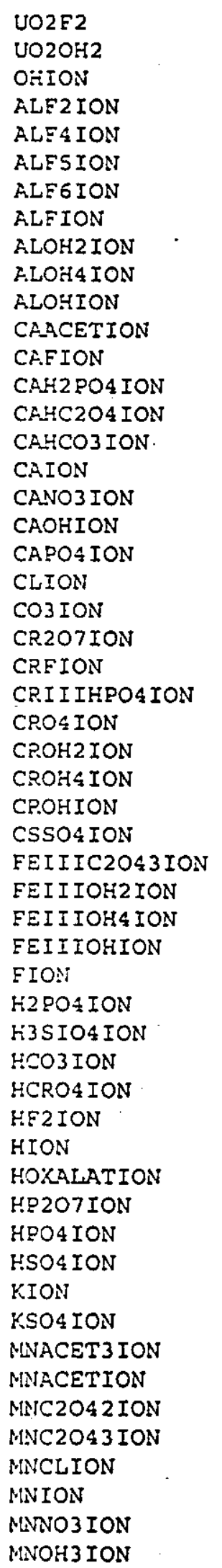

\begin{tabular}{|c|c|}
\hline $1.8464 \mathrm{E}-29$ & 0.0 \\
\hline $6.1029 E-18$ & 0.0 \\
\hline 0.0443675 & 0.0 \\
\hline $1.3045 E-27$ & 0.0 \\
\hline 1. $8144 E-23$ & 0.0 \\
\hline $2.3728 E-22$ & 0.0 \\
\hline $1.6580 \mathrm{E}-21$ & 0.0 \\
\hline 0.0 & 0.0 \\
\hline $1.1292 \mathrm{E}-19$ & 0.0 \\
\hline 0.0350173 & 0.0 \\
\hline $7.4749 E-30$ & 0.0 \\
\hline $3.5527 E-13$ & 0.0 \\
\hline $1.9500 E-13$ & 0.0 \\
\hline $1.8641 E-21$ & 0.0 \\
\hline $1.4099 E-23$ & 0.0 \\
\hline $1.3466 \mathrm{E}-16$ & 0.0 \\
\hline $2.0228 E-12$ & 0.0 \\
\hline $8.0673 E-25$ & 0.0 \\
\hline $7.3996 \mathrm{E}-11$ & 0.0 \\
\hline $2.7978 \mathrm{E}-09$ & 0.0 \\
\hline 0.00228015 & 0.0 \\
\hline 0.00554273 & 0.0 \\
\hline $2.0940 E-20$ & 0.0 \\
\hline $5.37 \not 4 E-27$ & 0.0 \\
\hline $2.1793 \varepsilon-25$ & 0.0 \\
\hline $1.3112 \mathrm{E}-0.5$ & 0.0 \\
\hline $6.7602 \mathrm{E}-22$ & 0.0 \\
\hline $1.7712 \mathrm{E}-11$ & 0.0 \\
\hline $1.0726 \mathrm{E}-27$ & 0.0 \\
\hline $2.6550 \mathrm{E}-10$ & 0.0 \\
\hline $4.2403 E-30$ & 0.0 \\
\hline $1.0993 \mathrm{E}-22$ & 0.0 \\
\hline $4.0108 E-07$ & 0.0 \\
\hline 0.0 & 0.0 \\
\hline $7.1822 \mathrm{E}-04$ & 0.0 \\
\hline $1.8347 E-12$ & 0.0 \\
\hline $9.1765 E-24$ & 0.0 \\
\hline $2.7966 \mathrm{E}-07$ & 0.0 \\
\hline $6.1305 E-13$ & 0.0 \\
\hline $1.1511 E-14$ & 0.0 \\
\hline $4.3430 E-16$ & 0.0 \\
\hline $5.0448 E-15$ & 0.0 \\
\hline $1.8048 E-17$ & 0.0 \\
\hline $2.5852 E-0.5$ & 0.0 \\
\hline $7.8574 \mathrm{E}-18$ & 0.0 \\
\hline 0.00313637 & 0.0 \\
\hline $1.0144 E-06$ & 0.0 \\
\hline $6.6182 E-19$ & 0.0 \\
\hline $9.3395 E-18$ & 0.0 \\
\hline $4.4868 E-19$ & 0.0 \\
\hline $1.3040 E-15$ & 0.0 \\
\hline $2.8428 E-17$ & 0.0 \\
\hline $4.4641 E-16$ & 0.0 \\
\hline $2.8822 E-17$ & 0.0 \\
\hline $3.6747 E-08$ & 0.0 \\
\hline
\end{tabular}

0.0

0.0

0.0

0.0

0.0

0.0

0.0

0.0

0.0

0.0

0.0

0.0

0.0

0.0

0.0

0.0

0.0

0.0

0.0

0.0

0.0

0.0

0.0

0.0

0.0

0.0

0.0

0.0

0.0

0.0

0.0

0.0

0.0

0.0

0.0

0.0

0.0

0.0

0.0

0.0

0.0

0.0

0.0

0.0

0.0

0.0

0.0

0.0

0.0

0.0

0.0

0.0

0.0

0.0

0.0
0.0

0.0

0.0

0.0

0.0

0.0

0.0

0.0

0.0

0.0

0.0

0.0

0.0

0.0

0.0

0.0

0.0

0.0

0.0

0.0

0.0

0.0

0.0

0.0

0.0

0.0

0.0

0.0

0.0

0.0

0.0

0.0

0.0

0.0

0.0

0.0

0.0

0.0

0.0

0.0

0.0

0.0

0.0

0.0

0.0

0.0

0.0

0.0

0.0

0.0

0.0

0.0

0.0

0.0

0.0 


\section{RPP 5643 REV 0}

\begin{tabular}{|c|c|c|c|c|}
\hline MOH4 ION & $6.5722 E-06$ & 0.0 & 0.0 & 0.0 \\
\hline MOHION & $4.0618 E-13$ & 0.0 & 0.0 & 0.0 \\
\hline NA2FION & $7.3393 E-16$ & 0.0 & 0.0 & 0.0 \\
\hline NACOBION & $8.5440 \mathrm{E}-04$ & 0.0 & 0.0 & 0.0 \\
\hline NAION & 0.196831 & 0.0 & 0.0 & 0.0 \\
\hline NASO4ION & $1.3894 E-06$ & 0.0 & 0.0 & 0.0 \\
\hline NIACET3ION & $3.0538 \varepsilon-22$ & 0.0 & 0.0 & 0.0 \\
\hline NIACETION & $1.8437 \mathrm{E}-20$ & 0.0 & 0.0 & 0.0 \\
\hline $\mathrm{NIC} 2042 \mathrm{ION}$ & $6.4938 E-20$ & 0.0 & 0.0 & 0.0 \\
\hline NICLION & $1.9812 E-21$ & 0.0 & 0.0 & 0.0 \\
\hline NIFION & $2.3382 E-20$ & 0.0 & 0.0 & 0.0 \\
\hline NIION & $7.6348 E-19$ & 0.0 & 0.0 & 0.0 \\
\hline NINO3ION & $3.8514 E-20$ & 0.0 & 0.0 & 0.0 \\
\hline NIOH3ION & $2.2310 \Xi-08$ & 0.0 & 0.0 & 0.0 \\
\hline NIOHION & $8.3997 E-16$ & 0.0 & 0.0 & 0.0 \\
\hline NO2 ION & 0.0424944 & 0.0 & 0.0 & 0.0 \\
\hline NO3 ION & 0.0604452 & 0.0 & 0.0 & 0.0 \\
\hline A.CETATEION & $3.4526 E-04$ & 0.0 & 0.0 & 0.0 \\
\hline OKALATION & $4.7122 E-05$ & 0.0 & 0.0 & 0.0 \\
\hline 9207 ION & $1.8868 \mathrm{E}-19$ & 0.0 & 0.0 & 0.0 \\
\hline EOAION & $2.2402 \mathrm{E}-04$ & 0.0 & 0.0 & 0.0 \\
\hline PUIVOH2 ION & 0.0 & 0.0 & 0.0 & 0.0 \\
\hline PUIVOH3ION. & $6.3927 \mathrm{E}-20$ & 0.0 & 0.0 & 0.0 \\
\hline SO4 ION & $7.4940 E-04$ & 0.0 & 0.0 & 0.0 \\
\hline UO2AC3 ION & 0.0 & 0.0 & 0.0 & 0.0 \\
\hline UO2ACION & 0.0 & 0.0 & 0.0 & 0.0 \\
\hline UO2C2O43ION & $4.3005 E-26$ & 0.0 & 0.0 & 0.0 \\
\hline UO2 2032 ION & $4.4469 E-17$ & 0.0 & 0.0 & 0.0 \\
\hline $\mathrm{UO} 2 \mathrm{CO} 33 \mathrm{ION}$ & $7.1064 E-11$ & 0.0 & 0.0 & 0.0 \\
\hline UO2F3ION & $2.4970 \mathrm{E}-26$ & 0.0 & 0.0 & 0.0 \\
\hline UO2E 4 ION & $2.1272 E-25$ & 0.0 & 0.0 & 0.0 \\
\hline UO2EION & $5.8982 E-30$ & 0.0 & 0.0 & 0.0 \\
\hline UO2OHION & E. $4522 \mathrm{E}-25$ & 0.0 & 0.0 & 0.0 \\
\hline $\mathrm{NA2C2O4}$ & 0.0 & 0.494065 & 0.0 & 0.0 \\
\hline I:A2U2O7 & 0.0 & $4.2373 E-04$ & 0.0 & 0.0 \\
\hline CR2O3 & 0.0 & 0.0498352 & 0.0 & 0.0 \\
\hline EEIII203 & 0.0 & 0.00500188 & 0.0 & 0.0 \\
\hline $\mathrm{NA} 2 \mathrm{CO} 3$ & 0.0 & 0.22707 & 0.0 & 0.0 \\
\hline SHASSIO4 & 0.0 & 0.170768 & 0.0 & 0.0 \\
\hline \multirow[t]{2}{*}{$\mathrm{CACO} 3 . \mathrm{H} 2 \mathrm{O}$} & 0.0 & 0.0497273 & 0.0 & 0.0 \\
\hline & 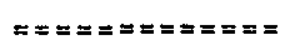 & 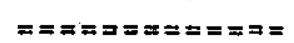 & 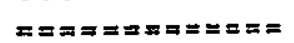 & 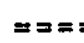 \\
\hline Total kg/hr & 110.23 & 1.67085 & 21.077 & 0.0 \\
\hline volume, L/hr & 79.3315 & 0.51955 & 37720.1 & 0.0 \\
\hline Enthalpy, $\mathrm{kJ} / \mathrm{hr}$ & $-1.2758 E+06$ & -17438.5 & $-2.7924 E+05$ & 0.0 \\
\hline Density, $\mathrm{kg} / \mathrm{L}$ & 1.3895 & 3.216 & $5.5877 E-04$ & \\
\hline Osmotic Pres, $\mathrm{mm}$ & $8.7175 E+05$ & & & \\
\hline Redox Pot, volts & 0.0 & & & \\
\hline E-Con, $1 / \mathrm{ohm}-\mathrm{cm}$ & 0.602702 & & & \\
\hline E-Con, $\mathrm{cm} 2 / \mathrm{ohm}-\mathrm{mol}$ & 61.3828 & & & \\
\hline Abs Visc, $c P$ & 10.4198 & & & \\
\hline Rel Visc & 44.9141 & & & \\
\hline Ionic strength & 18.975 & & & \\
\hline
\end{tabular}




\begin{tabular}{|c|c|c|c|c|c|}
\hline CASE & CELL & $\begin{array}{l}\text { TEMPERATURE } \\
\mathrm{C}\end{array}$ & $I$ & $\begin{array}{l}\text { H2OVAP } \\
\text { molefrac }\end{array}$ & $\begin{array}{l}\text { ACETACIDVAP } \\
\text { molefrac }\end{array}$ \\
\hline 1.000 & 1.000 & 40.00 & 12.99 & 0.0000 & 0.0000 \\
\hline 2.000 & 1.000 & 60.00 & 13.06 & 0.0000 & 0.0000 \\
\hline 3.000 & 1.000 & 80.00 & 13.10 & 0.0000 & 0.0000 \\
\hline 4.000 & 1.000 & 100.0 & 13.12 & 0.0000 & 0.0000 \\
\hline \multirow[t]{2}{*}{5.000} & 1.000 & 120.0 & 18.98 & 1.000 & $0.6315 E-11$ \\
\hline & & & $\begin{array}{l}\text { SOLFLOH (MOL) } \\
\text { mOl/hr } \\
30.55 \\
8.906 \\
8.812 \\
9.216 \\
12.24\end{array}$ & & $\begin{array}{l}\text { LIQELOW } \\
\text { mol/hr } \\
5403 . \\
5406 . \\
5408 . \\
5408 . \\
4231 .\end{array}$ \\
\hline $\begin{array}{l}\text { LIQFLOW } \\
\text { mol/hr }\end{array}$ & $\begin{array}{l}\text { ENTHAL } \\
\mathrm{kJ} / \mathrm{hr}\end{array}$ & $\begin{array}{l}\text { ENTHAV } \\
\mathrm{kJ} / \mathrm{hr}\end{array}$ & $\begin{array}{l}\text { ENTHAS } \\
\mathrm{kJ} / \mathrm{hr}\end{array}$ & $\begin{array}{l}\text { ENTHALPY } \\
\mathrm{kJ} / \mathrm{hr}\end{array}$ & $\begin{array}{l}\text { PRESSURE } \\
\text { mmig }\end{array}$ \\
\hline 5403 & $-0.1605 E+07$ & 0.0000 & $-0.4230 E+05$ & $-0.1648 E+07$ & 755.0 \\
\hline 5406 & $-0.1626 E+07$ & 0.0000 & $-0.1421 \mathrm{E}+05$ & $-0.1641 E+07$ & 755.0 \\
\hline 5408. & $-0: 16208+07$ & 0.0000 & $-0.1406 \mathrm{E}+05$ & $-0.1634 E+07$ & 755.0 \\
\hline 5408 & $-0.1613 E+07$ & 0.0000 & $-0.1404 E+05$ & $-0.1627 E+07$ & 755.0 \\
\hline$\$ 23 I$ & $-0.1276 E+07$ & $-0.2792 E+06$ & $-0.1744 E+05$ & $-0.1573 E+07$ & 755.0 \\
\hline KH2OVAP & AYH2O & АН 20 & KACETACIDVAP & PAYACETACID & AACETACIDAQ \\
\hline $\operatorname{Ln}()$ & $\operatorname{Ln}()$ & $\operatorname{Ln}()$ & $\operatorname{Ln}()$ & $\operatorname{Ln}()$ & $\operatorname{Ln}()$ \\
\hline 2.617 & 0.0000 & -0.5142 & 7.144 & 0.0000 & 1.776 \\
\hline 1.626 & 0.0000 & -0.4884 & 6.176 & 0.0000 & 1.728 \\
\hline 0.7649 & 0.0000 & -0.4742 & 5.361 & 0.0000 & 1.732 \\
\hline $0.1089 E-01$ & 0.0000 & -0.4615 & 4.691 & 0.0000 & 1.736 \\
\hline-0.6528 & $-0.7207 E-02$ & -0.6667 & $\leq .158$ & $-0.1798 E-01$ & 2.510 \\
\hline KCO2VAP & $\mathrm{AYCO} 2$ & ACO2A.Q & KH:2E2VAP & AYH2F2 & AL2F2AQ \\
\hline $\operatorname{Ln}()$ & $\operatorname{Ln}()$ & $\operatorname{Ln}()$ & $\operatorname{Ln}(1)$ & $\operatorname{In}()$ & $\operatorname{Ln}()$ \\
\hline-3.751 & 0.0000 & 2.730 & 8.957 & 0.0000 & 1.776 \\
\hline-4.112 & 0.0000 & 2.740 & 7.866 & 0.0000 & 1.728 \\
\hline-4.365 & 0.0000 & 2.738 & 6.886 & 0.0000 & 1.732 \\
\hline-4.537 & 0.0000 & 2.670 & 6.002 & 0.0000 & 1.736 \\
\hline-4.647 & $-0.4899 E-03$ & 3.666 & 5.202 & $-0.8814 E-02$ & 2.510 \\
\hline KACET2VAP & AYACET2 & AACET $2 A Q$ & KH2SO4VAP & AYH2SO4 & $\mathrm{AH} 2 \mathrm{SO} 4 \mathrm{AQ}$ \\
\hline In() & $\operatorname{Ln}()$ & $\operatorname{Ln}(1)$ & $\operatorname{Ln}()$ & $\operatorname{Ln}()$ & Ln () \\
\hline-6.305 & 0.0000 & 1.776 & 11.21 & 0.0000 & 1.776 \\
\hline-6.960 & 0.0000 & 1.728 & 9.086 & 0.0000 & 1.728 \\
\hline-7.541 & 0.0000 & 1.732 & 7.025 & 0.0000 & 2.732 \\
\hline-8.059 & 0.0000 & 1.736 & 5.015 & 0.0000 & 1.736 \\
\hline-8.525 & $-0.1798 E-01$ & 2.510 & 3.044 & $-0.5555 E-01$ & 2.510 \\
\hline KHCLVAP & AYHCL & AHCLAQ & KHEVAP & AYHE & AHFAQ \\
\hline $\operatorname{Ln}(1)$ & $\operatorname{Ln}()$ & $\operatorname{Ln}()$ & $\operatorname{Ln}()$ & $\operatorname{In}()$ & $\operatorname{Ln}(1)$ \\
\hline-0.5504 & 0.0000 & 1.776 & 9.012 & 0.0000 & 3.018 \\
\hline-1.145 & 0.0000 & 1.728 & 7.894 & 0.0000 & 3.087 \\
\hline-1.706 & 0.0000 & 1.732 & 6.777 & 0.0000 & 3.345 \\
\hline-2.240 & 0.0000 & 1.736 & 5.661 & 0.0000 & 3.736 \\
\hline-2.755 & $-0.1083 E-02$ & 2.510 & 4.544 & $-0.8874 \Sigma-02$ & 6.194 \\
\hline
\end{tabular}




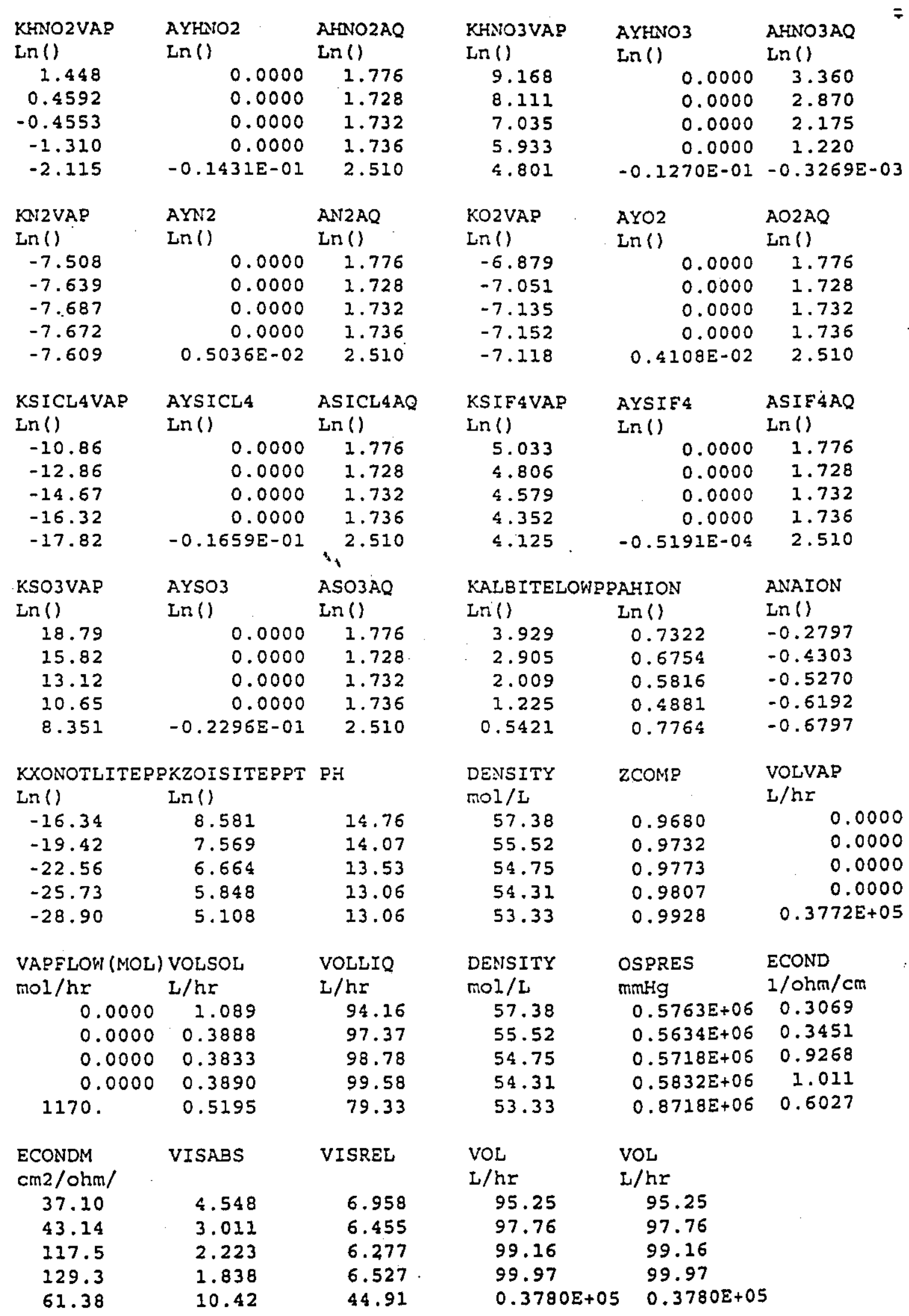




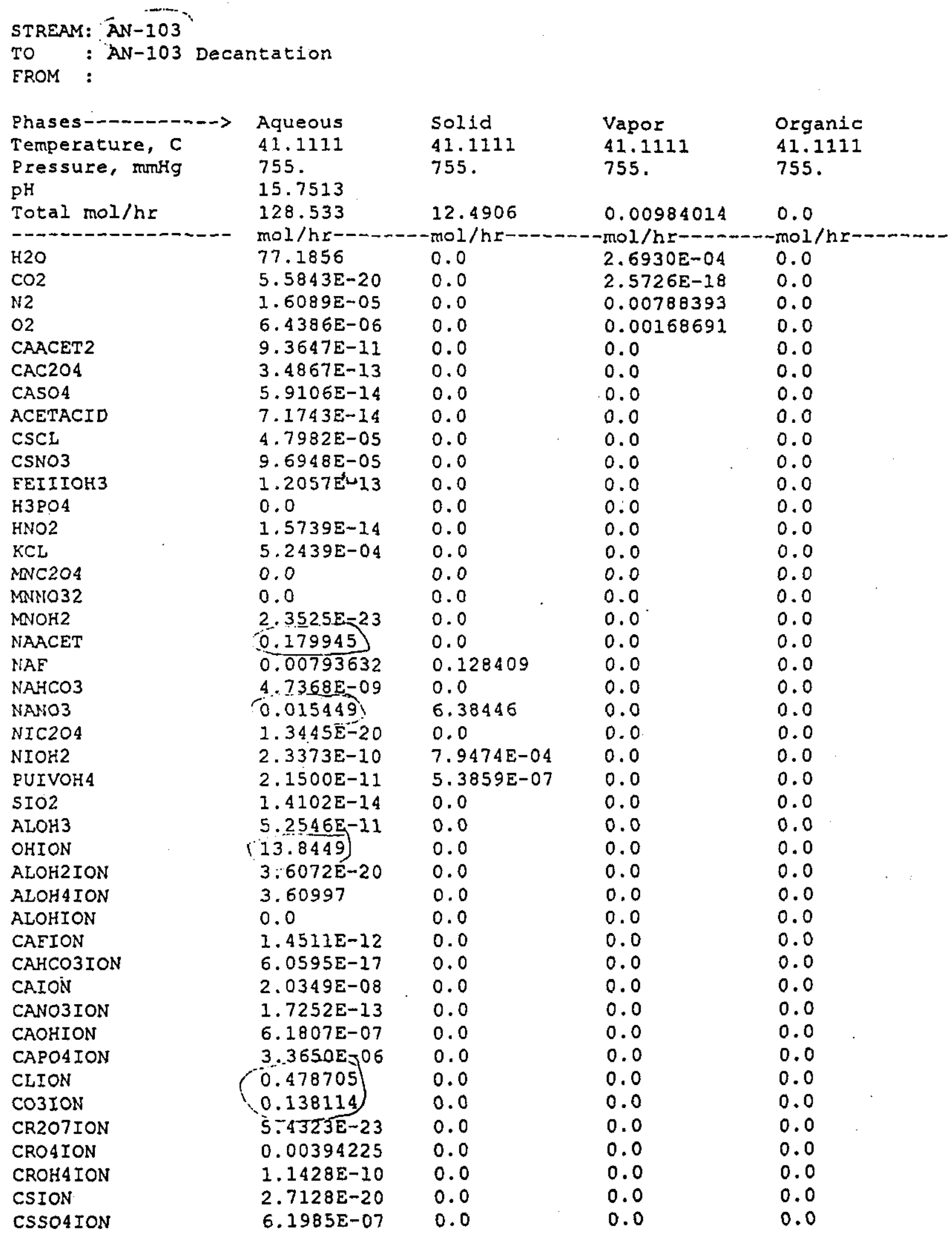


RPP 5643 REV 0

\begin{tabular}{|c|c|c|c|c|}
\hline FEIIIOH2ION & $9.1566 \mathrm{E}-23$ & 0.0 & 0.0 & 0.0 \\
\hline EEIIIOH 4 ION & $2.1955 \mathrm{E}-05$ & 0.0 & 0.0 & 0.0 \\
\hline EION & 0.0116704 & 0.0 & 0.0 & 0.0 \\
\hline H2PO4 ION & $1.7196 \mathrm{E}-15$ & 0.0 & 0.0 & 0.0 \\
\hline H2SIO4ION & $1.0868 \mathrm{E}-07$ & 0.0 & 0.0 & 0.0 \\
\hline H3SIO4ION & $4.2414 \mathrm{E}-08$ & 0.0 & 0.0 & 0.0 \\
\hline HCO3ION & $1.4250 \mathrm{E}-08$ & 0.0 & 0.0 & 0.0 \\
\hline HCRO4ION & $6.4096 \mathrm{E}-14$ & 0.0 & 0.0 & 0.0 \\
\hline HION & $1.5967 \mathrm{E}-16$ & 0.0 & 0.0 & 0.0 \\
\hline HOXALATION & $6.8501 E-18$ & 0.0 & 0.0 & 0.0 \\
\hline HP2O7ION & $5.8412 \mathrm{E}-24$ & 0.0 & 0.0 & 0.0 \\
\hline HPO4ION & $2.0542 \mathrm{E}-05$ & 0.0 & 0.0 & 0.0 \\
\hline HSOAION & $2.1260 E-19$ & 0.0 & 0.0 & 0.0 \\
\hline KION & 0.798564 & 0.0 & 0.0 & 0.0 \\
\hline KSO 4 ION & $5.8036 \mathrm{E}-04$ & 0.0 & 0.0 & 0.0 \\
\hline MNCLION & $1.5399 E-30$ & 0.0 & 0.0 & 0.0 \\
\hline MNION & $3.9401 E-28$ & 0.0 & 0.0 & 0.0 \\
\hline MNNO3ION & 0.0 & 0.0 & 0.0 & 0.0 \\
\hline MNOH 3 ION & $2.8301 \mathrm{E}-18$ & 0.0 & 0.0 & 0.0 \\
\hline MNOH 4 ION & $6.7288 \mathrm{E}-15$ & 0.0 & 0.0 & 0.0 \\
\hline MOHION & $1.1510 \mathrm{E}-25$ & 0.0 & 0.0 & 0.0 \\
\hline NA2FION & $1.4109 \mathrm{E}-05$ & 0.0 & 0.0 & 0.0 \\
\hline NACO3ION & 0.0971993 & 0.0 & 0.0 & 0.0 \\
\hline NAION & 24.9246 & 0.0 & 0.0 & 0.0 \\
\hline NASO 4 ION & $8.9698 \mathrm{E}+04$ & 0.0 & 0.0 & 0.0 \\
\hline NIC2042ION & $1.1189 \mathrm{E}-22$ & 0.0 & 0.0 & 0.0 \\
\hline NIION & $1.9913 \mathrm{E}-18$ & 0.0 & 0.0 & 0.0 \\
\hline NIOH3ION & $7.7322 \mathrm{E}-04$ & 0.0 & 0.0 & 0.0 \\
\hline NIOHION & $2.2450 \mathrm{E}-15$ & 0.0 & 0.0 & 0.0 \\
\hline NO2ION & 4.40835 & 0.0 & 0.0 & 0.0 \\
\hline NO3ION & 2.62892 & 0.0 & 0.0 & 0.0 \\
\hline ACETATEION & 0.110739 & 0.0 & 0.0 & 0.0 \\
\hline OXALATION & $2.6131 \mathrm{E}-04$ & 0.0 & 0.0 & 0.0 \\
\hline P207ION & $1.0321 \mathrm{E}-15$ & 0.0 & 0.0 & 0.0 \\
\hline PO4ION & 0.0746228 & 0.0 & 0.0 & 0.0 \\
\hline PUIVOH 3 ION & $1.0759 \mathrm{E}-20$ & 0.0 & 0.0 & 0.0 \\
\hline SO4ION & 0.0109723 & 0.0 & 0.0 & 0.0 \\
\hline UO2 2032 ION & $1.3301 \mathrm{E}-24$ & 0.0 & 0.0 & 0.0 \\
\hline UO2CO33ION & $4.7783 E-18$ & 0.0 & 0.0 & 0.0 \\
\hline CASOHPO 43 & 0.0 & $1.1763 E-04$ & 0.0 & 0.0 \\
\hline $\mathrm{CAOH} 2$ & 0.0 & 0.0171147 & 0.0 & 0.0 \\
\hline CROH 3 & 0.0 & 0.035486 & 0.0 & 0.0 \\
\hline EEOOH & 0.0 & 0.00360197 & 0.0 & 0.0 \\
\hline KALSIO4 & 0.0 & 0.0607984 & 0.0 & 0.0 \\
\hline $\mathrm{NA} 2 \mathrm{C} 2 \mathrm{O} 4$ & 0.0 & 0.181594 & 0.0 & 0.0 \\
\hline $\mathrm{NA} 2 \mathrm{CO} 3.1 \mathrm{H} 2 \mathrm{O}$ & 0.0 & 0.745869 & 0.0 & 0.0 \\
\hline NA2U2O7 & 0.0 & $1.5087 \mathrm{E}-04$ & 0.0 & 0.0 \\
\hline $\mathrm{NA} 6 \mathrm{SO} 42 \mathrm{CO} 3$ & 0.0 & 0.0437092 & 0.0 & 0.0 \\
\hline NANO2 & 0.0 & 3.41862 & 0.0 & 0.0 \\
\hline $\mathrm{MNO} 2$ & 0.0 & $8.1331 E-04$ & 0.0 & 0.0 \\
\hline NAALO $22.2 .5 \mathrm{H} 20$ & 0.0 & 1.38416 & 0.0 & 0.0 \\
\hline NACL & 0.0 & 0.0849064 & 0.0 & 0.0 \\
\hline & 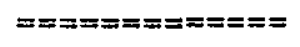 & 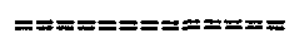 & 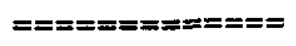 & 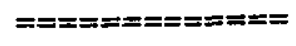 \\
\hline Total kg/hr & 3.00449 & 1.22717 & $2.7969 \Sigma-04$ & 0.0 \\
\hline Volume, $\mathrm{L} / \mathrm{hr}$ & 2.07585 & 0.56373 & 0.2554 & 0.0 \\
\hline Enthalpy, $k J / h r$ & -38052.6 & -10118.6 & -0.0605471 & 0.0 \\
\hline Density, kg/l & 1.4474 & 2.1769 & 0.00109509 & \\
\hline
\end{tabular}


RPP 5643 REV 0

\section{ATTACHMENT 2}

Thermal Conductivity of Aqueous Solutions

C-30 


\section{RPP 5643 REV 0}

\section{Thermal Conductivity of the aqueous phase of the waste in $A N-103$}

Graham MacLean's analyses consider the diluted waste after the supernatant liquid has been decanted and the tank has been refilled with water. Note that it is reasonable to expect that the resulting solution has characteristics similar to the liquid that was decanted. The dominant species dissolved in the aqueous phase are expected to be sodium nitrate and sodium nitrite. The supernatant liquid is estimated to have a specific gravity of 1.33 .

Based on data of Tables 3-91 and 3-92 in Perry's Chemical Handbook, $\mathrm{NaNO}_{3}$ and $\mathrm{NaNO}_{2}$ have about the same density versus weight perçent dissolved characteristics. Though the data for $\mathrm{NaNO}_{2}$ is incomplete but the data that is presented is very similar, to that of $\mathrm{NaNO}_{3}$.

Using the supernatant Iiquid density of 1.33 that is consistent with 45 wto and the equation 3-131 of Rerry's Chemical Handbook for estimating the dilute solution thermal conductivity and associated constants in Table 3-341 (Perry's Chemical Handbook)

$$
\mathrm{KH} 2020:=0.353 \frac{\mathrm{Btu}}{\mathrm{hr}-\mathrm{ft}-\mathrm{R}}=0.001458 \frac{\mathrm{cal}}{\mathrm{sec}-\mathrm{cm}-\mathrm{K}}
$$

Assuming that the only species is $\mathrm{NaNO}_{3}$ and further assume that since the initial undiluted case has almost twice the vapor pressure suppression of this case that there is twice the concentration and hence that the effect is twice as strong. 


$$
\begin{aligned}
\mathrm{K} \Delta:= & \left.\frac{\frac{\frac{450}{1.33}}{85} \cdot\left(-6.978 \times 10^{-5}\right)}{4.186}\right) \cdot 1 \frac{\mathrm{cal}}{\mathrm{sec}-\mathrm{cm}-\mathrm{K}} \\
& =-6.636 \times 10^{-05} \frac{\mathrm{cal}}{\mathrm{sec}-\mathrm{cm}-\mathrm{K}}
\end{aligned}
$$

$$
\mathrm{Ksoln}:=\mathrm{KH} 2020+2 \cdot \mathrm{K} \Delta=0.001325 \frac{\mathrm{cal}}{\mathrm{sec}-\mathrm{cm}-\mathrm{K}}
$$

Kratio $:=\frac{\text { Ksoln }}{\text { KH2O20 }}=0.909$

So it is assumed that the thermal conductivity of the aqueous phase in $A N-103$ is about $90 \%$ of that of water for all cases. 
RPP 5643 REV 0

ATTACHMENT 3

Estimation of Non-Convective Slurry Volume

For Diluted Waste

C-33 
Fluffed Sludge Height and Volume Fraction of Solids for Diluted Case

$$
\begin{aligned}
& \text { psolids }:=3 \frac{\mathrm{gm}}{\mathrm{cm}^{3}}=187.3 \frac{\mathrm{lbm}}{\mathrm{ft}^{3}} \\
& \text { pliquid }:=1.33 \frac{\mathrm{gm}}{\mathrm{cm}^{3}}=83.03 \frac{1 \mathrm{bm}}{\mathrm{ft}^{3}} \\
& \text { Van3waste }:=958000 \mathrm{gal}=1.281 \times 10^{+05 \mathrm{ft}^{3}}
\end{aligned}
$$

Insoluble solids in the mixed waste is $0.5 \%$ by volume.

$$
\begin{aligned}
& \text { Vesolids }:=0.005 \\
& \text { Vsolids }:=\text { Van3waste } \cdot \text { Vfsolids }=640.3 \mathrm{ft}^{3} \\
& \text { Wsolids }:=\text { Vsolids } \cdot \text { psolids }=1.199 \times 10^{+05} 1 \mathrm{bm} \\
& \text { Vliquidinwaste }:=\text { Van3waste }- \text { Vsolids }=1.274 \times 10^{+05} \mathrm{ft}^{3} \\
& \text { WIiquidinwaste }:=\text { Vliquidinwaste } \cdot \rho 1 i q u i d \\
& =1.058 \times 10^{+07} \mathrm{lbm}
\end{aligned}
$$

Assuming that the final compacted sludge will have 40 wt: solids and the initial non-convective fluffed sludge will have 20 wt: solids,

$$
\text { Wpercentsolids }:=0.2
$$


Wliqinsldg $:=$ Wsolids $\frac{1-\text { Wpercentsolids }}{\text { Wpercentsolids }}=4.797 \times 10^{+05} \mathrm{Ibm}$

$$
\begin{aligned}
& \text { Vliquidinsldg }:=\frac{\text { wliginsldg }}{\text { Pliquid }}=5777 \mathrm{ft}^{3} \\
& \text { Vsolidsinsldg }:=\text { Vsolids }=640.3 \mathrm{ft}^{3} \\
& \text { Vsldginitial }:=\text { Vliquidinsldg }+ \text { Vsolidsinsldg }=6418 \mathrm{ft}^{3} \\
& \text { Atank }=4418 \mathrm{ft}^{2} \\
& \text { Hsldginitial }:=\frac{\text { Vsldginitial }}{\text { Atank }}=1.453 \mathrm{ft}
\end{aligned}
$$

So it is assumed that the fluffed sludge height will be about $1.46 \mathrm{ft}$.

$$
\text { Vfsolidsinsldg }:=\frac{\text { Vsolidsinsldg }}{\text { Vsldginitial }}=0.09977
$$

The fluffed sludge of the diluted waste will contain 10 volume percent of solids.

$$
\text { undilutedsludgeheightff2 }:=\frac{410000 \mathrm{gal}}{\text { Atank }} \cdot 2=24.81 \mathrm{ft}
$$

The undiluted Tank 241-AN-103 waste will have a fluffed sludge height of $24.8 \mathrm{ft}$. 
RPP 5643 REV 0

\section{ATTACHMENT 4}

\section{Estimation of Undiluted Waste}

Solids Volume 


\section{RPP 5643 REV 0}

\section{Estimation of Undiluted Waste solids Volume}

$$
\begin{aligned}
& \text { sludgedensity }:=1.62 \frac{\mathrm{gm}}{\mathrm{cm}^{3}}=101.1 \frac{\mathrm{lbm}}{\mathrm{ft}^{3}} \\
& \text { massofwater }:=0.31 \cdot \text { sludgedensity }=31.35 \frac{\mathrm{lbm}}{\mathrm{ft}^{3}} \\
& \text { massofsalts }:=0.49 \cdot \frac{\text { massofwater }}{0.51}=30.12 \frac{1 \mathrm{bm}}{\mathrm{ft}^{3}}
\end{aligned}
$$

Slurry has 318 of water. Supernatant has 518 of water and 498 of salts.

$$
\begin{aligned}
& \text { massofsolids }:=\text { sludgedensity - massofwater - massofsalts } \\
& =39.66 \frac{1 \mathrm{bm}}{\mathrm{ft}^{3}}
\end{aligned}
$$

$$
\text { massofliquid := massofwater + massofsalts }=61.47 \frac{\mathrm{Ibm}}{\mathrm{ft}^{3}}
$$

densityofliquid $:=1.46 \frac{\mathrm{gm}}{\mathrm{cm}^{3}}$

volumefractionofliquid $:=\frac{\text { massofliquid }}{\text { densityofliquid }}=0.6745$

$$
\text { densityofsolids }:=\frac{\text { massofsolids }}{1-\text { volumefractionofliquid }}=121.8 \frac{1 \mathrm{bm}}{\mathrm{ft}^{3}}
$$




\section{RPP 5643 REV 0}

$$
\begin{aligned}
& \text { densityofsolids }=\frac{1.951 \frac{\mathrm{gm}}{\mathrm{cm}^{3}}}{\text { volumefractionofsolids }:=1-\text { volumefractionofliquid }} \\
& =0.3255
\end{aligned}
$$

For a fluff factor of 2, the solids volume fraction will be half of this value.

$$
\begin{aligned}
& \text { volumefractionofsolidsff2 }:=\frac{\text { volumefractionofsolids }}{2} \\
& =0.1628 \quad \mathrm{it}
\end{aligned}
$$

The undiluted Tank 241-AN-103 waste will have a fluffed sludge containing 0.163 volume fraction of solids. 
RPP 5643 REV 0

ATTACHMENT 5

Liquid Vapor Pressure Undiluted Waste 
Sathyanarayana, $\mathrm{K}$

From:

Sent:

To:

MacLean, Graham T

Subject:

Tuesday, July 11, 2000 8:45 AM

Sathyanarayana, $K$

AN-103 Partial Pressure

Sathya,

Since the water partial pressure is equal to the water activity times the water vapor pressure at the same temperature, ESP predictions of water activity are used to estimate the water partial pressure above tank wastes. The value of the water activity calculated by ESP for the expected future composition of Tank AN-103 waste is .318. In the attached ESP survey, the value of AH2O found near the end of the file is the natural log of the water activity, or $\ln (-1.145)$, which $=.318$. You indicated that I gave you a value of .31 , so I obviously truncated the calculated value to two significant digits.

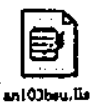

Graham Maclean

Fluor Federal Services

Process Engineering 509-372-0405 


\section{RPP 5643 REV 0}

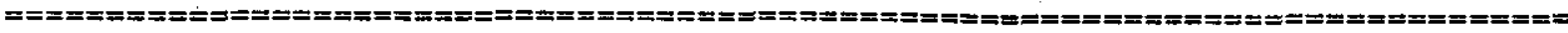
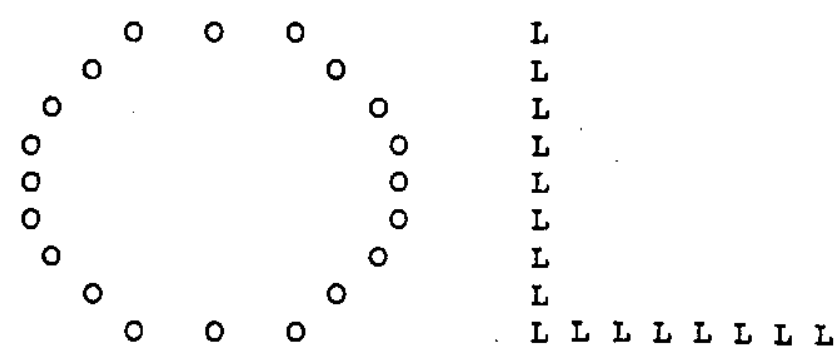

$I I I I$
$I$
$I$
$I$
$I$
$I$
$I$
$I I I I$

ENVIRONMENTALSSIMUIATION PROG RAM

$V=6.4$ March 1, 2000

SURVEY: $A N-103$

CHEMISTRY MODEL: GENTANK

THIS FILE NAME: AN103BSU.IIS

DATE: $07 / 11 / 2000$ 
RPP 5643 REV 0

TABLE OF CONTENTS
STREAM SECTION

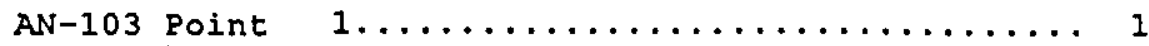
SCALING INDEX SECTION

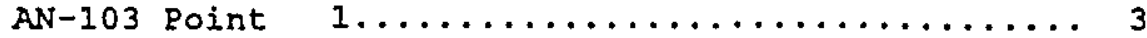

C -42 


\section{RPP 5643 REV 0}

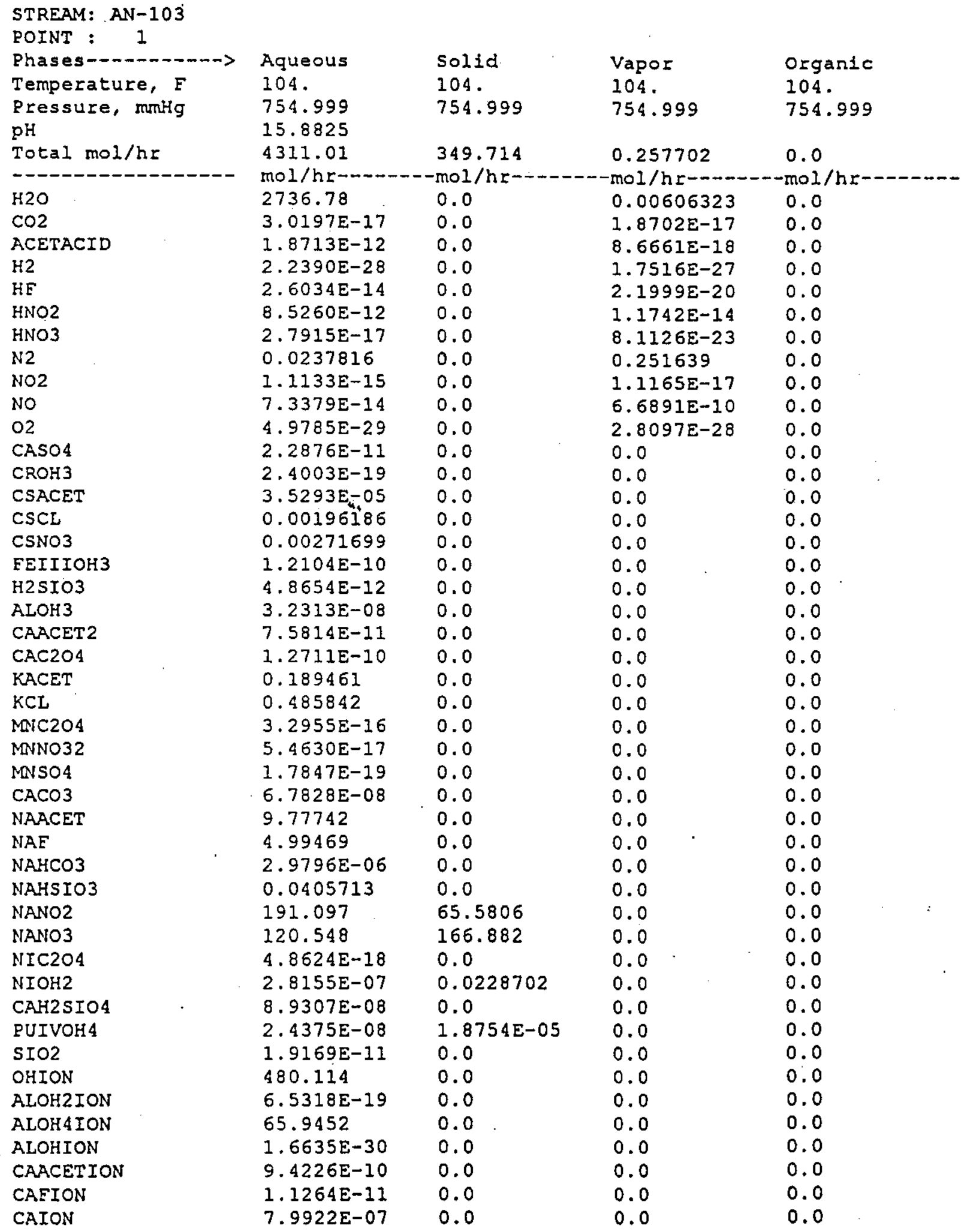


RPP 5643 REV 0

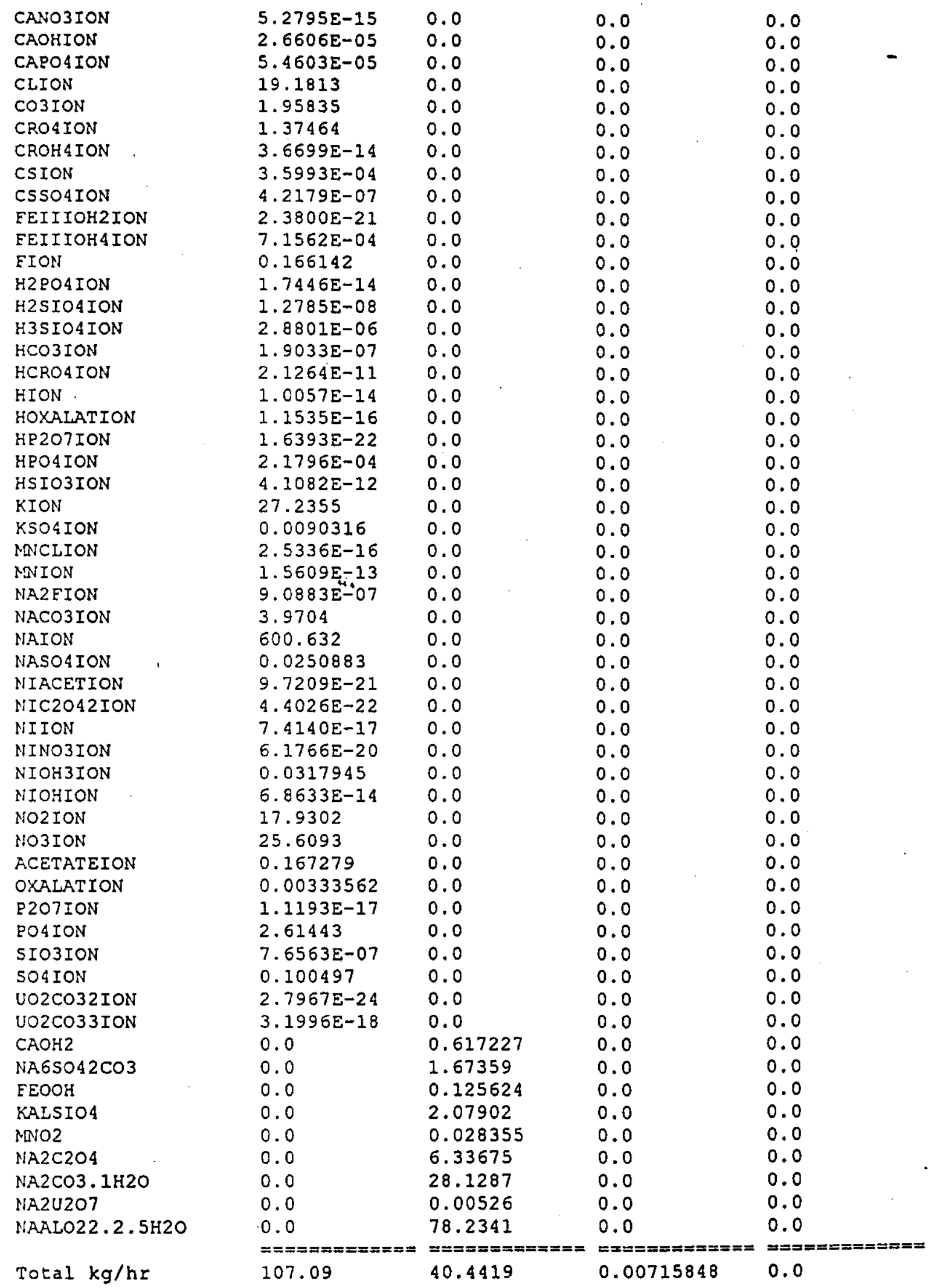




\section{RPP 5643 REV 0}

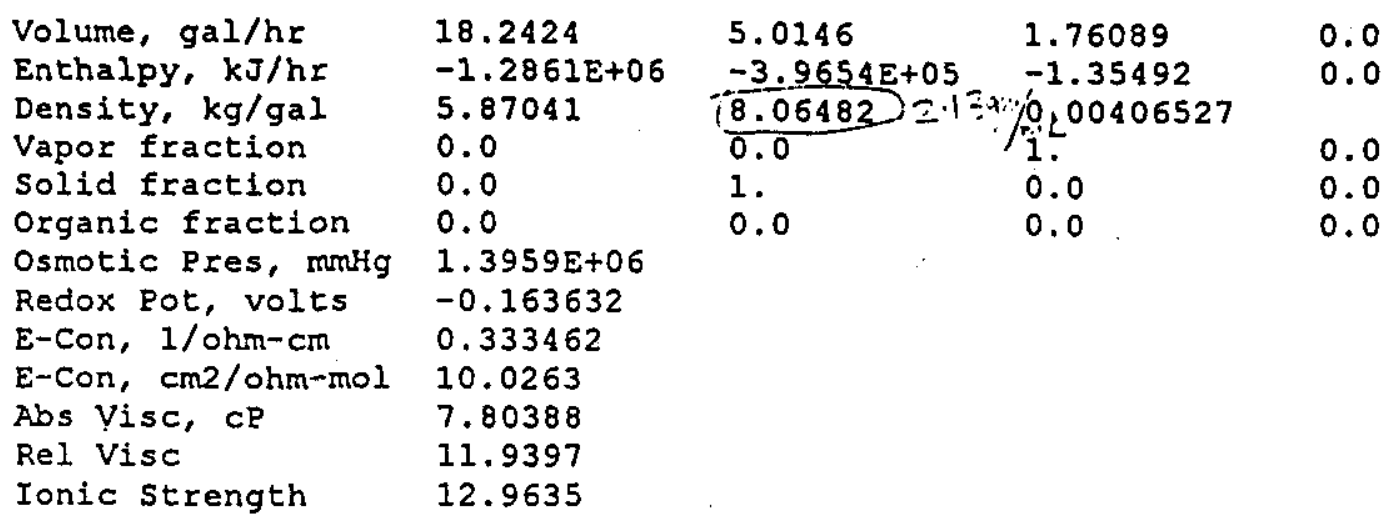




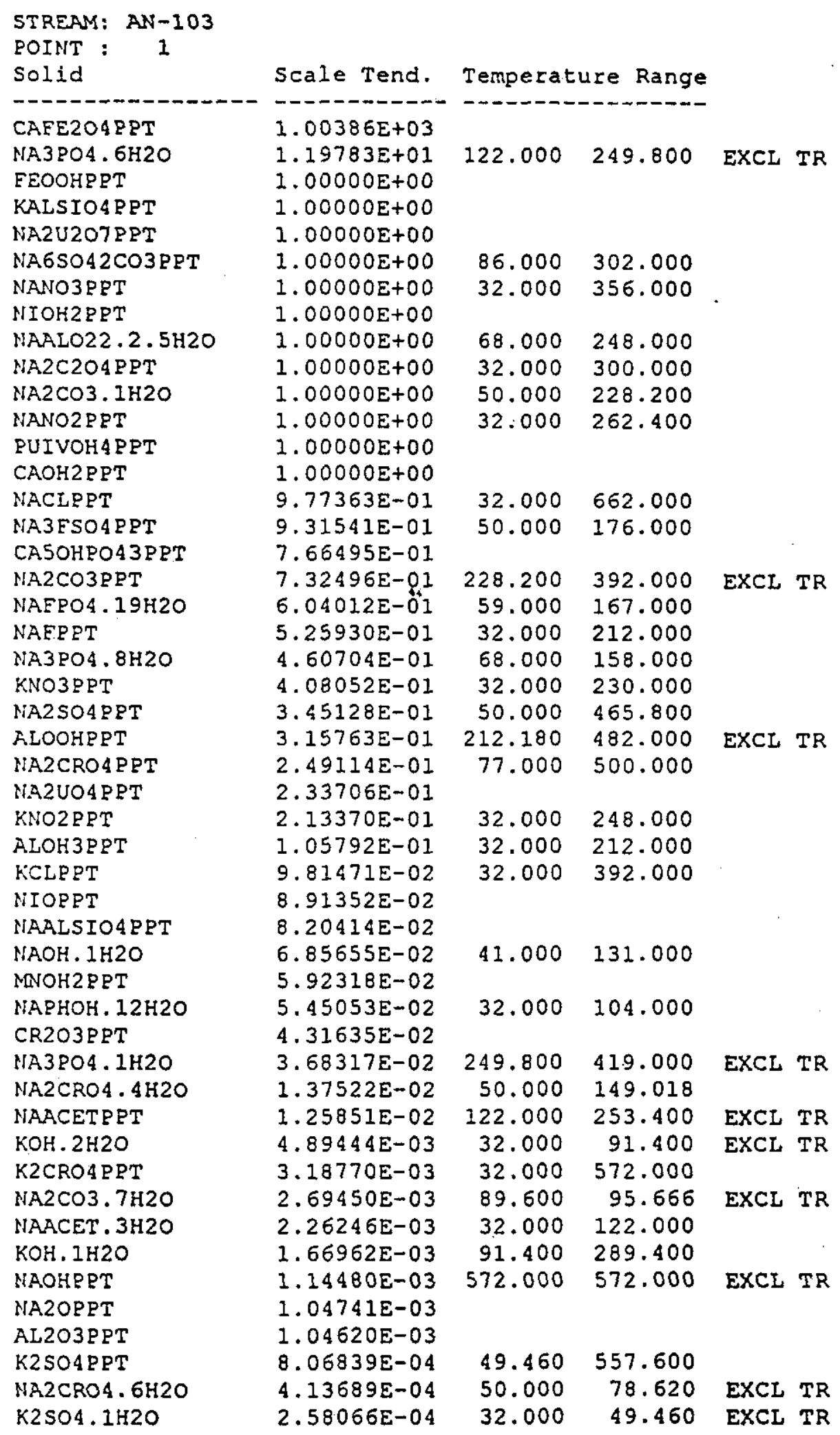




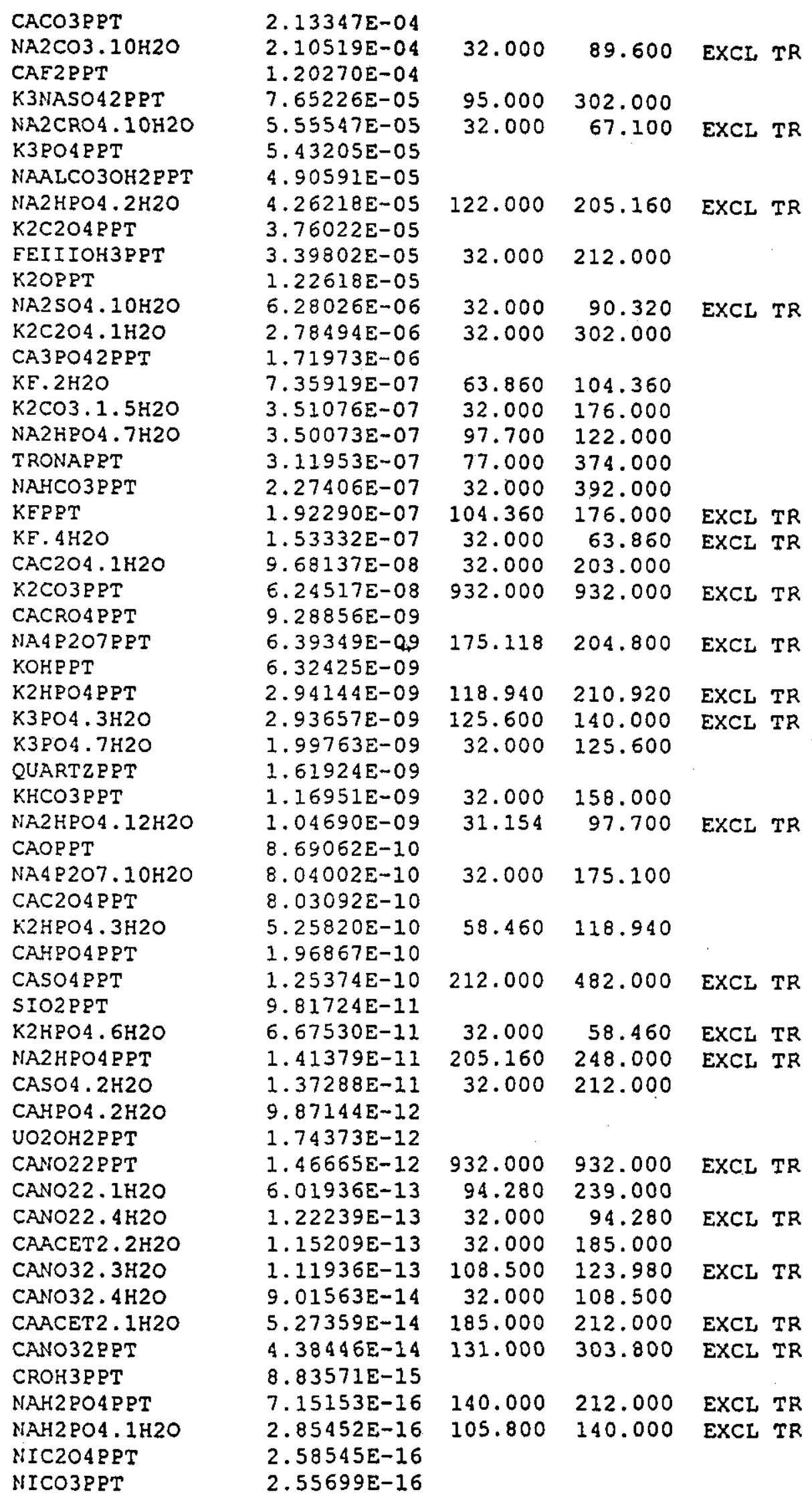




\begin{tabular}{|c|c|c|c|c|}
\hline KH2 PO4 P PT & $1.43780 \mathrm{E}-16$ & 32.000 & 194.000 & \\
\hline $\mathrm{NAH} 2 \mathrm{PO} 4.2 \mathrm{H} 2 \mathrm{O}$ & $1.17030 E-16$ & 32.000 & 105.800 & \\
\hline $\mathrm{NIC2O} 4.2 \mathrm{H} 2 \mathrm{O}$ & $4.26919 \varepsilon-18$ & 32.000 & 77.000 & EXCL TR \\
\hline P4010PPT & $2.00067 E-19$ & & & \\
\hline $\mathrm{NINO} 32.2 \mathrm{H} 2 \mathrm{O}$ & $6.46030 \mathrm{E}-23$ & 185.720 & 247.640 & EXCL? \\
\hline ALPOAPPT & $1.21136 \mathrm{E}-24$ & & & \\
\hline NINO32. $4 \mathrm{H} 2 \mathrm{O}$ & $7.82258 E-25$ & 129.200 & 185.720 & EXCL $T$ \\
\hline NINO32. $6 \mathrm{H} 20$ & $1.79599 E-25$ & 32.000 & 129.200 & \\
\hline $\mathrm{NIE2}, 4 \mathrm{H} 2 \mathrm{O}$ & $1.59375 E-25$ & 32.000 & 194.000 & \\
\hline NINO32PRT & $1.46937 \mathrm{E}-25$ & & & \\
\hline EEIIIPO $4.2 \mathrm{H} 2 \mathrm{O}$ & $2.27922 \mathrm{E}-26$ & & & \\
\hline $\mathrm{NISO} 4.6 \mathrm{H} 2 \mathrm{O}$ & $2.58616 \mathrm{E}-27$ & 88.160 & 212.000 & \\
\hline NI SO $4.7 \mathrm{H} 20$ & $6.62220 \mathrm{E}-28$ & 32.000 & 88.160 & EXCL TR \\
\hline NA5P3010PPT & $4.80566 \varepsilon-29$ & & & \\
\hline NA5P3010.6H2O & $1.80184 E-29$ & & & \\
\hline NISO4PRT & $2.12565 \mathrm{E}-30$ & 932.000 & 932.000 & EXCL \\
\hline CRO3PPT & $7.56852 \mathrm{E}-31$ & & & \\
\hline CAACET 2PPT & $3.76528 \mathrm{E}-31$ & & & \\
\hline EEIII PO 4 RPT & $2.71056 \mathrm{E}-31$ & & & \\
\hline ALF3 . 3H2O & $1.11381 E-32$ & 32.000 & 194.000 & \\
\hline OXALACPPT & $5.91571 E-33$ & & & \\
\hline OXALAC. $2 \mathrm{H} 2 \mathrm{O}$ & $1.00035 E-33$ & 32.000 & 194.360 & \\
\hline UO2NO32. 3H2O & $1.00000 \mathrm{E}-35$ & 137.480 & 235.400 & EXCL 7 \\
\hline $\mathrm{VO} 2 \mathrm{NO} 32.6 \mathrm{H} 2 \mathrm{O}$ & $1.00000 \mathrm{E}-35$ & 32.000 & 137.480 & \\
\hline CAH $28042.1 \mathrm{H} 2 \mathrm{O}$ & $1.00000 E-3.5$ & & & \\
\hline UO2 SO4. 3420 & $1.00000 \mathrm{E}-35$ & 32.000 & 308.480 & \\
\hline UO2SO4RPT & $1.00000 \mathrm{E}-35$ & & & \\
\hline K1ALSO4.12H2O & $1.00000 \Xi-35$ & 32.000 & 167.000 & \\
\hline NI 3PO42RPT & $1.00000 \mathrm{E}-35$ & & & \\
\hline K1ALSO4PRT & $1.00000 \mathrm{E}-35$ & 440.330 & 442.130 & EXCL 7 \\
\hline CAH2 PO42PRT & $1.00000 E-35$ & & & \\
\hline ALNO $33.6 \mathrm{H} 2 \mathrm{O}$ & $1.00000 \mathrm{E}-35$ & 224.600 & 264.200 & EXCL $T$ \\
\hline ALNO33 $.8 \mathrm{H} 20$ & $1.00000 \mathrm{E}-35$ & 176.000 & 224.600 & EXCL TR \\
\hline ALNO33.9H2O & $1.00000 \mathrm{E}-35$ & 32.000 & 176.000 & \\
\hline $\mathrm{CR} 2 \mathrm{SO} 4.14 \mathrm{H} 2 \mathrm{O}$ & $1.00000 \mathrm{E}-35$ & 77.000 & 77.000 & EXCL T \\
\hline $\mathrm{CR} 2504.16 \mathrm{H} 20$ & $1.00000 E-35$ & 77.000 & 77.000 & EXCL T \\
\hline NA3204PPT & $1.00000 E-35$ & 419.000 & 662.000 & EXCL TR \\
\hline CR2SO4PRT & $1.00000 \mathrm{E}-35$ & & & \\
\hline CRE3PRT & $1.00000 \mathrm{E}-35$ & & & \\
\hline CRIIINO $33.9 \mathrm{H} 20$ & $1.00000 E-35$ & 32.000 & 95.000 & EXCL TR \\
\hline AL2 $2 \mathrm{SO} 43.6 \mathrm{H} 2 \mathrm{O}$ & $1.00000 E-35$ & & & \\
\hline UO2N032 PPT & $1.00000 \mathrm{E}-35$ & & & \\
\hline UVIF6PRT & $1.00000 \mathrm{E}-35$ & & & \\
\hline FE2SO43PPT & $1.00000 \mathrm{E}-35$ & & & \\
\hline FEIIIE3PRT & $1.00000 E-35$ & & & \\
\hline EEIIINO33.9H2O & $1.00000 E-35$ & 32.000 & 104.000 & \\
\hline QUIVE 4 P PT & $1.00000 \mathrm{E}-35$ & & & \\
\hline A.L2SO43PPT & $1.00000 \mathrm{E}-35$ & & & \\
\hline AL2s043.16 120 & $1.00000 E-35$ & 32.000 & 190.400 & \\
\hline KAL3SULEATPPT & $1.00000 \mathrm{E}-35$ & & & \\
\hline U022 P2O7PRT & $1.00000 \mathrm{E}-35$ & & & \\
\hline $\mathrm{U} 023 \mathrm{PO} 42.4 \mathrm{H} 2 \mathrm{O}$ & $1.00000 \mathrm{E}-35$ & & & \\
\hline UO2 3PO42 PPT & $1.00000 \mathrm{E}-35$ & & & \\
\hline $\mathrm{U} 2 \mathrm{C} 204.3 \mathrm{H} 20$ & $1.00000 \mathrm{E}-35$ & 32.000 & 212.000 & \\
\hline $\mathrm{UO} 2 \mathrm{~F} 2.3 \mathrm{H} 2 \mathrm{O}$ & $1.00000 \mathrm{E}-35$ & & & \\
\hline UO2E2PRT & $1.00000 E-35$ & & & \\
\hline $\mathrm{UO} 2 \mathrm{NO} 32.2 \mathrm{H} 2 \mathrm{O}$ & $1.00000 \mathrm{E}-35$ & 235.400 & 363.200 & \\
\hline
\end{tabular}


ESP $V-6.4$

CASE

1.000
CELL

1.000
SURVEY-VARIABLES

TEMPERATURE I

F

104.0

$\begin{array}{llllll}\text { CO2VAP } & \text { ACETACIDVAP } & \text { H2VAP } & \text { HCOOHVAP } & \text { HFVAP } & \text { HNO2VAP } \\ \text { moles } & \text { moles } & \text { moles } & \text { moles } & \text { moles } & \text { moles } \\ 0.1870 \mathrm{E}-16 & 0.8666 \mathrm{E}-17 & 0.1752 \mathrm{E}-26 & 0.0000 & 0.2200 \mathrm{E}-19 & 0.1174 \mathrm{E}-13\end{array}$

$\begin{array}{ll}\text { HNO3VAP } & \text { N2VAP } \\ \text { moles } & \text { moles } \\ 0.8113 E-22 & 0.2516\end{array}$

CHAAQ

moles
$07 / 11 / 2000$ PAGE $\div 5$

$\begin{array}{ll}\text { H2OVAP } & \text { CH4VAP } \\ \text { moles } & \text { moles } \\ 0.6063 E-02 & 0.0000\end{array}$ $\begin{array}{ll}\text { NH3VAP } & \text { NO2VAP } \\ \text { moles } & \text { moles } \\ 0.0000 & 0.1117 \mathrm{E}-16\end{array}$
12.96

\begin{tabular}{|c|c|c|}
\hline $07 / 11$ & 12000 & PAGE \\
\hline $\begin{array}{l}\text { H2OVAP } \\
\text { moles } \\
0.6063 \mathrm{E}-02\end{array}$ & $\begin{array}{l}\text { CH4VA } \\
\text { moles }\end{array}$ & .0000 \\
\hline
\end{tabular}

NOVAP

moles

O2VAP

moles

$0.1117 E-16$

$0.66898-09$

$0.2810 E-27$

\section{ACETACIDAQ} moles

$\mathrm{H} 2 \mathrm{AQ}$

moles

$0.1871 E-11$

$0.2239 E-27$

HCOOHAQ

moles

0.0000

HEAQ

moles

$0.2603 \mathrm{E}-13$

$\begin{array}{llll}\text { N2AQ } & \text { NH3AQ } & \text { NO2AQ } & \text { NOAQ } \\ \text { moles } & \text { moles } & \text { moles } & \text { moles } \\ 0.2378 E-01 & 0.0000 & 0.1113 E-14 & 0.7338 E-13\end{array}$

$0.8526 \mathrm{E}-11 \quad 0.2791 \mathrm{E}-16$

$0.2378 \varepsilon-01$

0.0000

$0.1113 \mathrm{E}-14$

$0.7338 \mathrm{E}-13$

$\begin{array}{llllll}\text { O2AQ } & \text { CASO4AQ } & \text { AGNO2AQ } & \text { AGCLAQ } & \text { CROH3AQ } & \text { CSACETAQ } \\ \text { moles } & \text { moles } & \text { moles } & \text { moles } & \text { moles } & \text { moles } \\ 0.4979 E-28 & 0.2288 E-10 & 0.0000 & 0.0000 & 0.2400 E-18 & 0.3529 E-04\end{array}$

\section{CSCLAQ}

moles

0.1962 E-02

CSGLYCOLAQ
moles 0.0000

CSNOZAQ

moles

$0.2717 \mathrm{E}-02$

EEIIIOH $3 A Q$ moles

$0.1210 \mathrm{E}-09$

GLYCOLACIDAQAGOHAQ

moles

0.0000

moles

0.0000

\begin{tabular}{|c|c|c|c|c|c|}
\hline $\begin{array}{l}\text { H2SIO3AQ } \\
\text { moles }\end{array}$ & $\begin{array}{l}\text { ALOH } 3 A Q \\
\text { moles }\end{array}$ & $\begin{array}{l}\text { BIOH } 3 A Q \\
\text { moles }\end{array}$ & $\begin{array}{l}\text { HGCL2AQ } \\
\text { moles }\end{array}$ & $\begin{array}{l}\text { HGOH } 2 \text { AQ } \\
\text { moles }\end{array}$ & $\begin{array}{l}\text { CAACET2AQ } \\
\text { moles } \\
0.7581 \mathrm{E}-10\end{array}$ \\
\hline
\end{tabular}




\section{RPP 5643 REV 0}

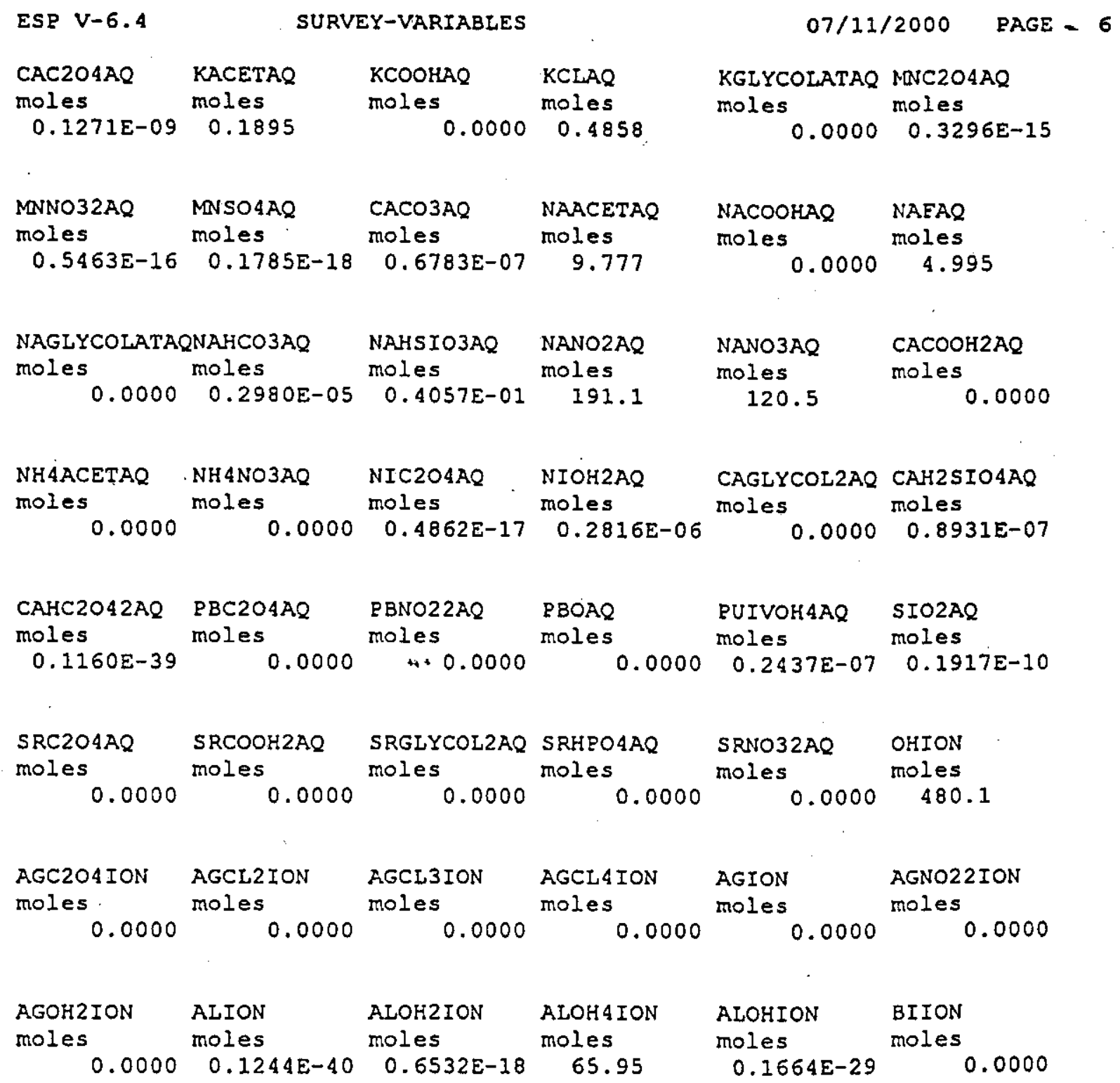




\section{RPP 5643 REV 0}

\begin{tabular}{|c|c|c|c|c|c|}
\hline ESP V-6.4 & \multicolumn{2}{|c|}{ SURVEY-VARIABLES } & & \multicolumn{2}{|c|}{$07 / 11 / 2000$} \\
\hline $\begin{array}{l}\text { BIOH } 4 \text { ION } \\
\text { moles } \\
\qquad 0.0000\end{array}$ & $\begin{array}{l}\text { CAACETION } \\
\text { moles } \\
0.9423 E-09\end{array}$ & $\begin{array}{l}\text { CACOOHION } \\
\text { moles } \\
\quad 0.0000\end{array}$ & $\begin{array}{l}\text { CACTRTION } \\
\text { moles } \\
0.0000\end{array}$ & $\begin{array}{l}\text { CAEDTAION } \\
\text { moles } \\
\qquad 0.0000\end{array}$ & $\begin{array}{l}\text { CAEION } \\
\text { moles } \\
\quad 0.1126 \mathrm{E}-10\end{array}$ \\
\hline $\begin{array}{l}\text { CAGLYCOIION } \\
\text { moles } \\
0.0000\end{array}$ & $\begin{array}{l}\text { CAION } \\
\text { moles } \\
0.7992 \mathrm{E}-06\end{array}$ & $\begin{array}{l}\text { CANO3ION } \\
\text { moles } \\
0.5280 E-14\end{array}$ & $\begin{array}{l}\text { CAOHION } \\
\text { moles } \\
0.2661 \mathrm{E}-04\end{array}$ & $\begin{array}{l}\text { CAPO4ION } \\
\text { moles } \\
\quad 0.5460 \mathrm{E}-04\end{array}$ & $\begin{array}{l}\text { CITRATION } \\
\text { moles } \\
\quad 0.0000\end{array}$ \\
\hline $\begin{array}{l}\text { CLION } \\
\text { moles } \\
\quad 19.18\end{array}$ & $\begin{array}{l}\text { co3ION } \\
\text { moles } \\
1.958\end{array}$ & $\begin{array}{l}\text { COOHION } \\
\text { moles } \\
0.0000\end{array}$ & $\begin{array}{l}\text { CRIIIHPO } 4 \text { ION } \\
\text { moles } \\
\quad 0.2764 \mathrm{E}-42\end{array}$ & $\begin{array}{l}\text { NCRIIIION } \\
\text { moles } \\
0.0000\end{array}$ & $\begin{array}{l}\text { CRO4ION } \\
\text { moles } \\
1.375\end{array}$ \\
\hline $\begin{array}{l}\text { CROH } 4 \text { ION } \\
\text { moles } \\
\quad 0.3670 E-13\end{array}$ & $\begin{array}{l}\text { CSCTRTION } \\
\text { moles } \\
\quad 0.0000\end{array}$ & $\begin{array}{l}\text { CSGLYCOL } 2 \text { IO } \\
\text { moles } \\
\qquad 0.0000\end{array}$ & $\begin{array}{l}\text { NCSION } \\
\text { moles } \\
0.3599 \mathrm{E}-03\end{array}$ & $\begin{array}{l}\text { CSSO } 4 \text { ION } \\
\text { moles } \\
\quad 0.4218 \mathrm{E}-06\end{array}$ & $\begin{array}{l}\text { EDTAION } \\
\text { moles } \\
\qquad 0.0000\end{array}$ \\
\hline $\begin{array}{l}\text { FEIIIION } \\
\text { moles } \\
\qquad 0.0000\end{array}$ & $\begin{array}{l}\text { EEIIIOH2ION } \\
\text { moles } \\
\quad 0.2380 E-20\end{array}$ & $\begin{array}{l}\text { EEIIIOHAION } \\
\text { moles } \\
0.7156 E-03\end{array}$ & $\begin{array}{l}\text { EEIIIOHION } \\
\text { moles } \\
0.3344 \mathrm{E}-32\end{array}$ & $\begin{array}{l}\text { FION } \\
\text { moles } \\
0.1661\end{array}$ & $\begin{array}{l}\text { GLYCOLATION } \\
\text { moles } \\
\quad 0.0000\end{array}$ \\
\hline $\begin{array}{l}\text { H2PO4ION } \\
\text { moles. } \\
0.1745 E-13\end{array}$ & $\begin{array}{l}\text { H2SIO } 4 \text { ION } \\
\text { moles } \\
\quad 0.1279 \mathrm{E}-07\end{array}$ & $\begin{array}{l}\text { H3SIOAION } \\
\text { moles } \\
\quad 0.2880 \mathrm{E}-05\end{array}$ & $\begin{array}{l}\text { HCITRATION } \\
\text { moles } \\
0.0000\end{array}$ & $\begin{array}{l}\text { HCO3ION } \\
\text { moles } \\
\quad 0.1903 E-06\end{array}$ & $\begin{array}{l}\text { HCRO } 4 \text { ION } \\
\text { moles } \\
\quad 0.2126 \mathrm{E}-10\end{array}$ \\
\hline $\begin{array}{l}\text { HEDTAION } \\
\text { moles }\end{array}$ & $\begin{array}{l}\text { HSEO3ION } \\
\text { moles }\end{array}$ & $\begin{array}{l}\text { HION } \\
\text { moles }\end{array}$ & $\begin{array}{l}\text { HGCL } 3 \text { ION } \\
\text { moles }\end{array}$ & $\begin{array}{l}\text { HGCL } 4 \text { ION } \\
\text { moles }\end{array}$ & $\begin{array}{l}\text { HGEDTAION } \\
\text { moles }\end{array}$ \\
\hline 0.0000 & 0.0000 & $0.1006 \mathrm{E}-13$ & 0.0000 & 0.0000 & 0.0000 \\
\hline $\begin{array}{l}\text { HGION } \\
\text { moles }\end{array}$ & $\begin{array}{l}\text { HGNH } 32 \text { ION } \\
\text { moles }\end{array}$ & $\begin{array}{l}\text { HGNH33ION } \\
\text { moles }\end{array}$ & $\begin{array}{l}\text { HGNH } 34 \text { ION } \\
\text { moles }\end{array}$ & $\begin{array}{l}\text { HGOH } 3 \text { ION } \\
\text { moles }\end{array}$ & $\begin{array}{l}\text { HOXALATION } \\
\text { moles }\end{array}$ \\
\hline 0.0000 & 0.0000 & 0.0000 & 0.0000 & 0.0000 & $0.1153 \mathrm{E}-15$ \\
\hline
\end{tabular}




\section{RPP 5643 REV 0}

\begin{tabular}{|c|c|c|c|c|c|}
\hline ESP V-6.4 & SURV & EY-VARIABLES & & $07 / 11 /$ & 12000 \\
\hline $\begin{array}{l}\text { HP2O7ION } \\
\text { moles } \\
\quad 0.1639 E-21\end{array}$ & $\begin{array}{l}\text { HPBO2ION } \\
\text { moles } \\
0.0000\end{array}$ & $\begin{array}{l}\text { HEO4ION } \\
\text { moles } \\
\quad 0.2180 E-03\end{array}$ & $\begin{array}{l}\text { HSIO3ION } \\
\text { moles } \\
\quad 0.4108 \mathrm{E}-11\end{array}$ & $\begin{array}{l}\text { KCTRTION } \\
\text { moles } \\
\quad 0.0000\end{array}$ & $\begin{array}{l}\text { KEDTAION } \\
\text { moles } \\
\qquad 0.0000\end{array}$ \\
\hline $\begin{array}{l}\text { KGLYCOL2ION } \\
\text { moles } \\
0.0000\end{array}$ & $\begin{array}{l}\text { KION } \\
\text { moles } \\
\qquad 27.24\end{array}$ & $\begin{array}{l}\text { KSO4ION } \\
\text { moles } \\
0.9032 \mathrm{E}-02\end{array}$ & $\begin{array}{l}\text { LAION } \\
\text { moles } \\
\qquad 0.0000\end{array}$ & $\begin{array}{l}\text { MNCLION } \\
\text { moles } \\
\quad 0.2534 \mathrm{E}-15\end{array}$ & $\begin{array}{l}\text { MNEDTAION } \\
\text { moles } \\
\qquad 0.0000\end{array}$ \\
\hline $\begin{array}{l}\text { MNION } \\
\text { moles } \\
\quad 0.1561 \mathrm{E}-12\end{array}$ & $\begin{array}{l}\text { NA2EION } \\
\text { moles } \\
\quad 0.9088 E-06\end{array}$ & $\begin{array}{l}\text { NACO3ION } \\
\text { moles } \\
\quad 3.970\end{array}$ & $\begin{array}{l}\text { NACTRTION } \\
\text { moles } \\
\qquad 0.0000\end{array}$ & $\begin{array}{l}\text { NAEDTAION } \\
\text { moles } \\
\qquad 0.0000\end{array}$ & $\begin{array}{l}\text { MAION } \\
\text { moles } \\
600.6\end{array}$ \\
\hline $\begin{array}{l}\text { NASO } 4 \text { ION } \\
\text { moles } \\
0.2509 E-01\end{array}$ & $\begin{array}{l}\text { NH2CO2ION } \\
\text { moles } \\
\qquad 0.0000\end{array}$ & $\begin{array}{l}\text { NH4ION } \\
\text { moles } \\
\quad 0.0000\end{array}$ & $\begin{array}{l}\text { NH4SO ION } \\
\text { moles } \\
0.0000\end{array}$ & $\begin{array}{l}\text { NIACETION } \\
\text { moles } \\
0.9721 \mathrm{E}-20\end{array}$ & $\begin{array}{l}\text { NIC2042ION } \\
\text { moles } \\
\quad 0.4403 E-21\end{array}$ \\
\hline $\begin{array}{l}\text { NICTRTION } \\
\text { moles } \\
0.0000\end{array}$ & $\begin{array}{l}\text { NIEDTAION } \\
\text { moles } \\
\qquad 0.0000\end{array}$ & $\begin{array}{l}\text { NIION } \\
\text { moles } \\
\quad 0.7414 \mathrm{E}-16\end{array}$ & $\begin{array}{l}\text { NINH32ION } \\
\text { moles } \\
\quad 0.0000\end{array}$ & $\begin{array}{l}\text { NINH33ION } \\
\text { moles } \\
0.0000\end{array}$ & $\begin{array}{l}\text { NINH3ION } \\
\text { moles } \\
\qquad 0.0000\end{array}$ \\
\hline $\begin{array}{l}\text { NINO3ION } \\
\text { moles } \\
\quad 0.6177 \mathrm{E}-19\end{array}$ & $\begin{array}{l}\text { NIOH } 3 \text { ION } \\
\text { moles } \\
\quad 0.3179 E-01\end{array}$ & $\begin{array}{l}\text { NIOHEDTAION } \\
\text { moles } \\
0.0000\end{array}$ & $\begin{array}{l}\text { NIOHION } \\
\text { moles } \\
\quad 0.6863 E-13\end{array}$ & $\begin{array}{l}\text { NO2ION } \\
\text { moles } \\
\quad 17.93\end{array}$ & $\begin{array}{l}\text { NO3ION } \\
\text { moles } \\
25.61\end{array}$ \\
\hline $\begin{array}{l}\text { ACETATEION } \\
\text { Moles } \\
0.1673\end{array}$ & $\begin{array}{l}\text { OXALATION } \\
\text { Moles } \\
\quad 0.3336 \mathrm{E}-02\end{array}$ & $\begin{array}{l}\text { PBEDTAION } \\
\text { moles } \\
\qquad 0.0000\end{array}$ & $\begin{array}{l}\text { PBION } \\
\text { moles } \\
\quad 0.0000\end{array}$ & $\begin{array}{l}\text { PBNO23ION } \\
\text { moles } \\
\qquad 0.0000\end{array}$ & $\begin{array}{l}\text { PBNO2ION } \\
\text { moles } \\
\qquad 0.0000\end{array}$ \\
\hline $\begin{array}{l}\text { PBOHION } \\
\text { moles } \\
0.0000\end{array}$ & $\begin{array}{l}\text { PO4ION } \\
\text { moles } \\
2.614\end{array}$ & $\begin{array}{l}\text { PUIVION } \\
\text { moles } \\
\qquad 0.0000\end{array}$ & $\begin{array}{l}\text { SEO3ION } \\
\text { moles } \\
\qquad 0.0000\end{array}$ & $\begin{array}{l}\text { SEO4ION } \\
\text { moles } \\
0.0000\end{array}$ & $\begin{array}{l}\text { SIO3ION } \\
\text { Moles } \\
0.7656 \mathrm{E}-06\end{array}$ \\
\hline
\end{tabular}




\section{RPP 5643 REV 0}

\begin{tabular}{|c|c|c|c|c|c|}
\hline ESP V-6.4 & SURVE & SY-VARIABLES & & $07 / 11 /$ & $/ 2000$ \\
\hline $\begin{array}{l}\text { SO4ION } \\
\text { moles } \\
0.1005\end{array}$ & $\begin{array}{l}\text { SRACETION } \\
\text { moles } \\
0.0000\end{array}$ & $\begin{array}{l}\text { SRCOOHION } \\
\text { moles } \\
0.0000\end{array}$ & $\begin{array}{l}\text { SRCTRTION } \\
\text { moles } \\
0.0000\end{array}$ & $\begin{array}{l}\text { SREDTAION } \\
\text { moles } \\
\qquad 0.0000\end{array}$ & $\begin{array}{l}\text { SREION } \\
\text { moles } \\
\qquad 0.0000\end{array}$ \\
\hline $\begin{array}{l}\text { SRGLYCOLION } \\
\text { moles } \\
0.0000\end{array}$ & $\begin{array}{l}\text { SRION } \\
\text { moles } \\
\qquad 0.0000\end{array}$ & $\begin{array}{l}\text { SRNO3ION } \\
\text { moles } \\
\qquad 0.0000\end{array}$ & $\begin{array}{l}\text { SROHION } \\
\text { moles } \\
\qquad 0.0000\end{array}$ & $\begin{array}{l}\text { SRPO4ION } \\
\text { moles } \\
\qquad 0.0000\end{array}$ & $\begin{array}{l}\text { TCVIIO } 4 \text { ION } \\
\text { moles } \\
0.0000\end{array}$ \\
\hline $\begin{array}{l}\text { UO2CO32ION } \\
\text { moles } \\
0.2797 E-23\end{array}$ & $\begin{array}{l}\text { UO2 } 2033 I O N \\
\text { moles } \\
0.3200 E-17\end{array}$ & $\begin{array}{l}\text { UO2ION } \\
\text { Moles } \\
0.4750 \mathrm{E}-37\end{array}$ & $\begin{array}{l}\text { 2RION } \\
\text { moles } \\
\qquad 0.0000\end{array}$ & $\begin{array}{l}\text { H2OIN } \\
\text { moles } \\
1935 .\end{array}$ & $\begin{array}{l}\text { CH4IN } \\
\text { moles } \\
\qquad 0.0000\end{array}$ \\
\hline $\begin{array}{l}\text { CO2IN } \\
\text { moles } \\
\qquad 0.0000\end{array}$ & $\begin{array}{l}\text { ACETACIDIN } \\
\text { moles } \\
\qquad 0.0000\end{array}$ & $\begin{array}{l}\text { H2IN } \\
\text { moles } 0.0000\end{array}$ & $\begin{array}{l}\text { HCOOHIN } \\
\text { moles } \\
\qquad 0.0000\end{array}$ & $\begin{array}{l}\text { HEIN } \\
\text { moles } 0.0000\end{array}$ & $\begin{array}{l}\text { HNO2IN } \\
\text { moles } \\
272.9\end{array}$ \\
\hline $\begin{array}{l}\text { HNO3IN } \\
\text { moles } \\
314.8\end{array}$ & $\begin{array}{l}\text { N2IN } \\
\text { moles } \\
0.2754\end{array}$ & $\begin{array}{l}\text { NH3IN } \\
\text { moles } \\
40.0000\end{array}$ & $\begin{array}{l}\text { NO2IN } \\
\text { moles } 0.0000\end{array}$ & $\begin{array}{l}\text { NOIN } \\
\text { moles } \\
\qquad 0.0000\end{array}$ & $\begin{array}{l}\text { o2IN } \\
\text { molees } \\
0.7321 \mathrm{E}-01\end{array}$ \\
\hline $\begin{array}{l}\text { CAOH2IN } \\
\text { moles } \\
0.6173\end{array}$ & $\begin{array}{l}\text { CROH 3IN } \\
\text { moles } \\
1.237\end{array}$ & $\begin{array}{l}\text { CSOHIN } \\
\text { moles } \\
0.5075 \mathrm{E}-02\end{array}$ & $\begin{array}{l}\text { FEIIIOH3IN } \\
\text { moles } \\
0.1263\end{array}$ & $\begin{array}{l}\text { HGOH2IN } \\
\text { moles } \\
\qquad 0.0000\end{array}$ & $\begin{array}{l}\text { KOHIN } \\
\text { moles } \\
\qquad 0.0000\end{array}$ \\
\hline $\begin{array}{l}\text { LAOH3IN } \\
\text { moles } \\
\qquad 0.0000\end{array}$ & $\begin{array}{l}\text { MNOH2IN } \\
\text { moles } \\
0.2836 \mathrm{E}-01\end{array}$ & $\begin{array}{l}\text { NIOH } 2 \text { IN } \\
\text { moles } \\
0.5466 \mathrm{E}-01\end{array}$ & $\begin{array}{l}\text { PBOH2IN } \\
\text { moles } \\
\qquad 0.0000\end{array}$ & $\begin{array}{l}\text { PUIVOH4IN } \\
\text { moles } \\
0.1878 \mathrm{E}-04\end{array}$ & $\begin{array}{l}\text { SROH } 2 \text { IN } \\
\text { moles } \\
\qquad 0.0000\end{array}$ \\
\hline $\begin{array}{l}\text { Uo2OH2IN } \\
\text { moles } \\
\qquad 0.0000\end{array}$ & $\begin{array}{l}\text { ZROH4IN } \\
\text { moles } \\
\qquad 0.0000\end{array}$ & $\begin{array}{l}\text { NH4OHIN } \\
\text { moles } \\
\qquad 0.0000\end{array}$ & $\begin{array}{l}\text { CITRACIN } \\
\text { moles } \\
\quad 0.0000\end{array}$ & $\begin{array}{l}\text { HCLIN } \\
\text { moles } \\
19.61\end{array}$ & $\begin{array}{l}\text { H2CO3IN } \\
\text { moles } \\
35.73\end{array}$ \\
\hline
\end{tabular}




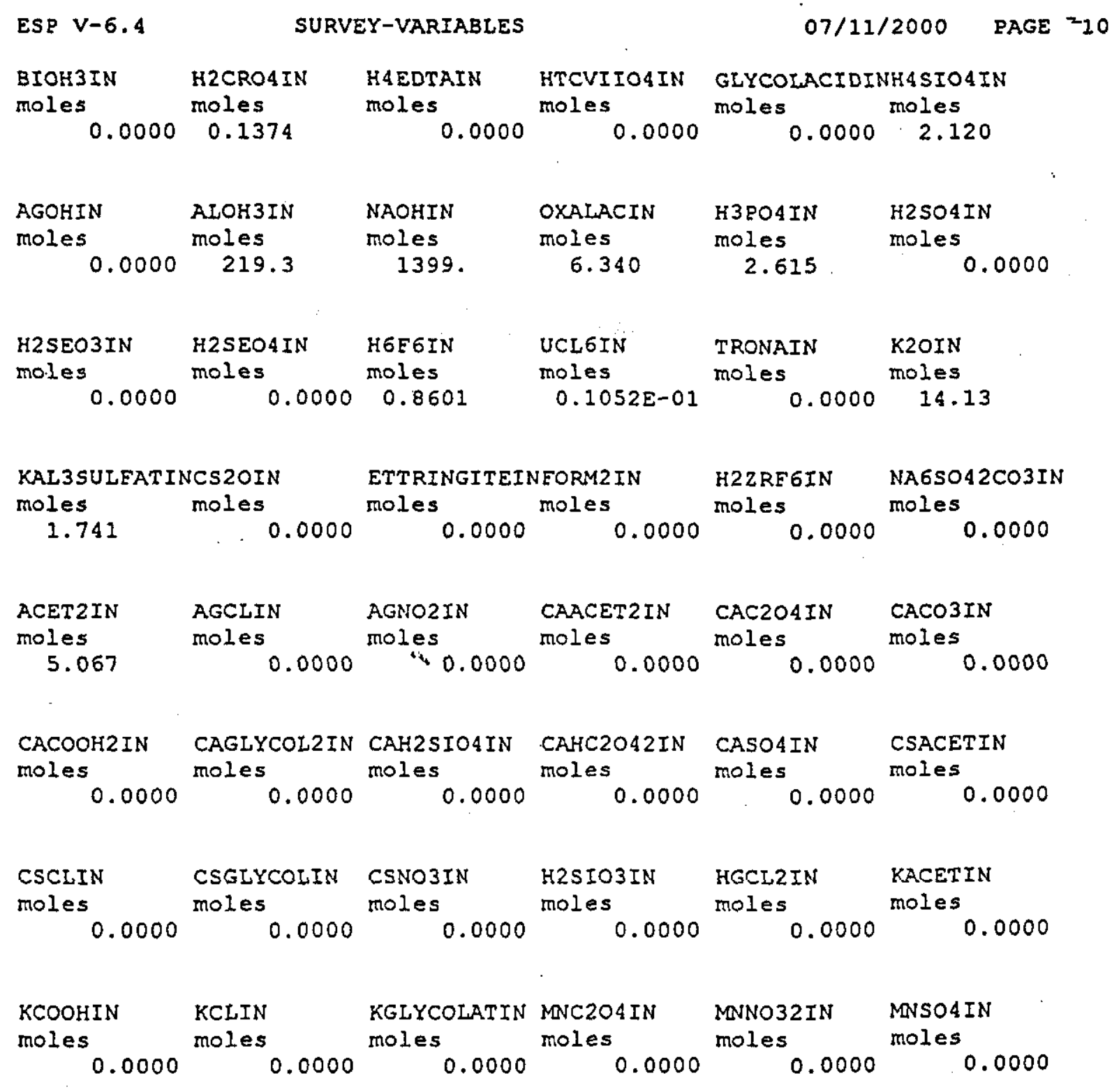




\section{RPP 5643 REV 0}

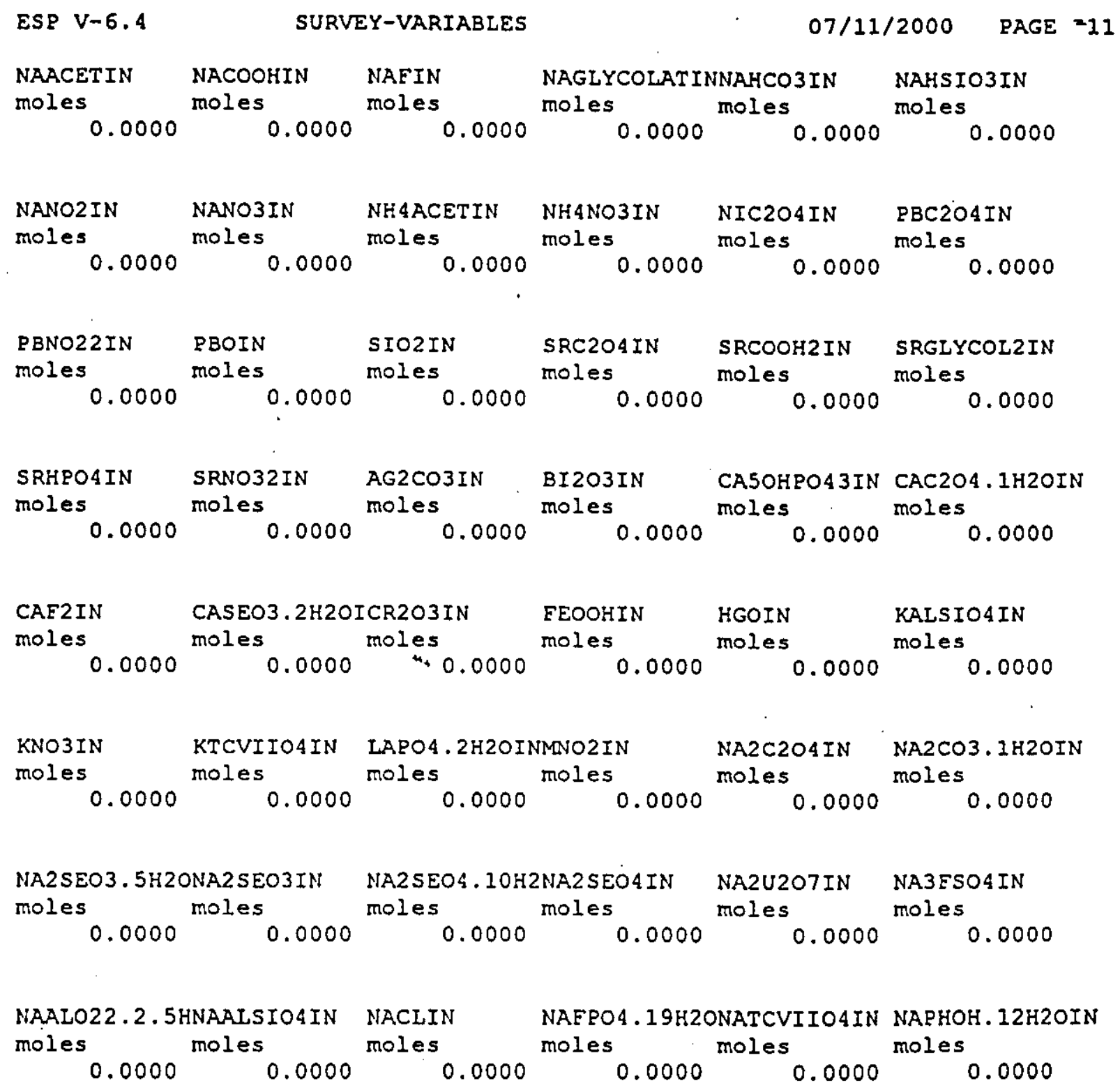




\begin{tabular}{|c|c|c|c|c|c|}
\hline ESP V-6.4 & SURVE & EY-VARIABLES & & $07 / 11 /$ & PAGE \\
\hline $\begin{array}{l}\text { NISEO3IN } \\
\text { moles } \\
\qquad 0.0000\end{array}$ & $\begin{array}{l}\text { PB3PO42IN } \\
\text { moles } \\
0.0000\end{array}$ & $\begin{array}{l}\text { SR3PO42IN } \\
\text { moles } \\
0.0000\end{array}$ & $\begin{array}{l}\text { SRCO3IN } \\
\text { moles } \\
\qquad 0.0000\end{array}$ & $\begin{array}{l}\mathrm{UO2NO} 2 \mathrm{IN} \\
\text { moles } \\
\quad 0.0000\end{array}$ & $\begin{array}{l}\text { UVIFGIN } \\
\text { moles } \\
\qquad 0.0000\end{array}$ \\
\hline $\begin{array}{l}\text { 2RO2IN } \\
\text { moles } \\
\qquad 0.0000\end{array}$ & $\begin{array}{l}\text { SOLMI } \\
\quad 0.0000\end{array}$ & $\begin{array}{l}\text { AG2CO3PRT } \\
\text { moles } \\
0.0000\end{array}$ & $\begin{array}{l}\text { ALOH 3RET } \\
\text { moles } \\
\qquad 0.0000\end{array}$ & $\begin{array}{l}\text { CASOHPO } 33 \mathrm{PPT} \\
\text { moles } \\
\cdot 0.0000\end{array}$ & $\begin{array}{l}\text { CCROH } 3 \text { RPT } \\
\text { moles } \\
0.0000\end{array}$ \\
\hline $\begin{array}{l}\text { EEOOHPRT } \\
\text { moles } \\
0.1256\end{array}$ & $\begin{array}{l}\text { KALSIO4PPT } \\
\text { moles } \\
2.079\end{array}$ & $\begin{array}{l}\text { MNO2PRT } \\
\text { moles } \\
\quad 0.2836 \mathrm{E}-01\end{array}$ & $\begin{array}{l}\text { NA2U207PPT } \\
\text { moles } \\
\quad 0.5260 \mathrm{E}-02\end{array}$ & $\begin{array}{l}\text { NA6SO } 42 \mathrm{CO} 3 \mathrm{PP} \\
\text { moles } \\
\quad 1.674\end{array}$ & $\begin{array}{l}\text { PNALSIO } 4 \text { PPT } \\
\text { moles. } \\
0.0000\end{array}$ \\
\hline $\begin{array}{l}\text { NANO3PPT } \\
\text { moles } \\
166.9\end{array}$ & $\begin{array}{l}\text { NIOH2PPT } \\
\text { moles } \\
0.2287 \mathrm{E}-01\end{array}$ & $\begin{array}{l}\text { NISEO3RET } \\
\text { moles } \\
0.0000\end{array}$ & $\begin{array}{l}\text { PBOH2PPT } \\
\text { moles } \\
\qquad 0.0000\end{array}$ & $\begin{array}{l}\text { ZRO2PPT } \\
\text { moles } \\
0.0000\end{array}$ & $\begin{array}{l}\text { SOLM2 } \\
\\
0.0000\end{array}$ \\
\hline $\begin{array}{l}\text { NAALO22.2.5H } \\
\text { moles } \\
\quad 78.23\end{array}$ & $\begin{array}{l}\text { HCAC2O4.1H2O } \\
\text { moles } \\
0.0000\end{array}$ & $\begin{array}{l}\text { CACO3PPT } \\
\text { moles } \\
\qquad 0.0000\end{array}$ & $\begin{array}{l}\text { CAE2PPT } \\
\text { moles } \\
\qquad 0.0000\end{array}$ & $\begin{array}{l}\text { CASEO } 3.2 \mathrm{H} 20 \\
\text { moles } \\
0.0000\end{array}$ & $\begin{array}{l}\text { PB3PO42PPT } \\
\text { moles } \\
0.0000\end{array}$ \\
\hline $\begin{array}{l}\text { U02N032PPT } \\
\text { moles } \\
\qquad 0.0000\end{array}$ & $\begin{array}{l}\text { UVIFбPRT } \\
\text { moles } \\
\qquad 0.0000\end{array}$ & $\begin{array}{l}\text { BI203PPT } \\
\text { moles } \\
0.0000\end{array}$ & $\begin{array}{l}\text { HGOPRT } \\
\text { moles } \\
\qquad 0.0000\end{array}$ & $\begin{array}{l}\text { LAOH3PPT } \\
\text { moles } \\
\qquad 0.0000\end{array}$ & $\begin{array}{l}\text { MAPO4. } 2 \mathrm{H} 20 \\
\text { moles } \\
0.0000\end{array}$ \\
\hline $\begin{array}{l}\text { SR3P042RPT } \\
\text { moles } \\
0.0000\end{array}$ & $\begin{array}{l}\text { SRCO3PRT } \\
\text { moles }\end{array}$ & $\begin{array}{l}\text { KCLPPT } \\
\text { moles }\end{array}$ & SOLM3 & $\begin{array}{l}\text { KNO3PRT } \\
\text { moles }\end{array}$ & $\begin{array}{l}\text { KTCVIIO } 4 \text { RPT } \\
\text { moles }\end{array}$ \\
\hline $\begin{array}{l}\text { NA2C204PPT } \\
\text { moles } \\
\quad 6.337\end{array}$ & $\begin{array}{l}\text { NA2CO3.1H2O } \\
\text { moles } \\
\quad 28.13\end{array}$ & $\begin{array}{l}\text { MACLPPT } \\
\text { moles } \\
\qquad 0.0000\end{array}$ & $\begin{array}{l}\text { NAFPO } 4.19 \mathrm{H} 20 \\
\text { moles } \\
0.0000\end{array}$ & $\begin{array}{l}\text { ONAEPET } \\
\text { moles } \\
\qquad 0.0000\end{array}$ & $\begin{array}{l}\text { NAHCO3PET } \\
\text { moles } \\
0.0000\end{array}$ \\
\hline
\end{tabular}




\section{RPP 5643 REV 0}

\begin{tabular}{|c|c|c|c|c|c|c|}
\hline ESP V-6.4 & \multicolumn{2}{|c|}{ SURVEY-VARIABLES } & \multicolumn{3}{|c|}{$07 / 11 / 2000 \quad$ PAGE $=13$} & $=13$ \\
\hline $\begin{array}{l}\text { NANO2PRT } \\
\text { moles } \\
\quad 65.58\end{array}$ & $\begin{array}{l}\text { NAPHOH. } 12 \mathrm{H} 2 \\
\text { moles } \\
0.0000\end{array}$ & $\begin{array}{l}\text { OPUIVOH } 4 \text { PPT } \\
\text { moles } \\
0.1875 E-04\end{array}$ & $\begin{array}{l}\text { NA3ESO } 4 \text { PPT } \\
\text { moles } \\
0.0000\end{array}$ & $\begin{array}{l}\text { NA2SE0 } 3.5 H 2 \\
\text { moles } 0.0000\end{array}$ & $\begin{array}{l}\text { ONA2 SEO3PRT } \\
\text { moles } \\
0.0000\end{array}$ & \\
\hline $\begin{array}{l}\text { NA2SE0 } 4.10 \mathrm{H} 2 \\
\text { moles } \\
0.0000\end{array}$ & $\begin{array}{l}\text { 25OLM4 } \\
\qquad 0.0000\end{array}$ & $\begin{array}{l}\text { NA2SEO4PRT } \\
\text { moles } \\
0.0000\end{array}$ & $\begin{array}{l}\text { NATCVIIO4PE } \\
\text { moles } \\
0.0000\end{array}$ & $\begin{array}{l}\text { TCAOH2RPT } \\
\text { moles }\end{array}$ & $\begin{array}{l}\text { CR203PPT } \\
\text { moles } \\
0.0000\end{array}$ & \\
\hline $\begin{array}{l}\text { SOLELOW (MOL) } \\
\text { mol/hr } \\
349.7\end{array}$ & $\begin{array}{l}\text { LIQFLOW } \\
\text { mol/hr } \\
4311 .\end{array}$ & $\begin{array}{l}\text { H2O } \\
\text { moles } \\
\quad 2737 .\end{array}$ & $\begin{array}{l}\text { LIQFLOW } \\
\text { mol/hr } \\
4311 .\end{array}$ & $\begin{array}{l}\text { ENTHAI } \\
\text { kJ/hI } \\
-0.1286 E+07\end{array}$ & $\begin{array}{l}\text { ENTHAV } \\
\mathrm{kJ} / \mathrm{hr} \\
-1.355\end{array}$ & \\
\hline $\begin{array}{l}\text { ENTHAS } \\
\mathrm{kJ} / \mathrm{hr} \\
-0.3965 \mathrm{E}+06\end{array}$ & $\begin{array}{l}\text { ENTHALPY } \\
\mathrm{kJ} / \mathrm{hr} \\
-0.1683 \mathrm{E}+07\end{array}$ & $\begin{array}{l}\text { PRESSURE } \\
\text { matig } \\
\quad 755.0\end{array}$ & $\begin{array}{l}\text { KH2OVAP } \\
\text { In () } \\
\quad 2.617\end{array}$ & $\begin{array}{l}\text { AYH2O } \\
\operatorname{Ln}(1) \\
-0.5865 E-02\end{array}$ & $\begin{array}{l}\text { AH } 20 \\
\operatorname{Ln}(1) \\
-1.145\end{array}$ & $h:(c, 3)=-1: i$ \\
\hline $\begin{array}{l}\text { KCH } 4 \text { VAE } \\
\operatorname{Ln}() \\
-6.705\end{array}$ & $\begin{array}{l}\text { AYCH } 4 \\
\operatorname{Ln}() \\
-0.9541 \mathrm{E}-03\end{array}$ & $\begin{array}{l}\text { ACH } 4 A Q \\
\operatorname{In}() \\
0.9 B 84 E-01\end{array}$ & $\begin{array}{l}\text { KCO2VAP } \\
\operatorname{Ln}(1) \\
-3.751\end{array}$ & $\begin{array}{l}A Y C O 2 \\
\operatorname{Ln}() \\
-0.2593 E-02\end{array}$ & $\begin{array}{l}\text { ACO2AQ } \\
\operatorname{Ln}(1) \\
1.015\end{array}$ & \\
\hline $\begin{array}{l}\text { KACETACIDVAE } \\
\text { Ln(1) } \\
\quad 7.144\end{array}$ & $\begin{array}{l}\text { PAYACETACID } \\
\text { Ln () } \\
-0.1024 \mathrm{E}-01\end{array}$ & $\begin{array}{l}\text { AACETACIDAQ } \\
\operatorname{Ln}() \\
0.9884 \mathrm{E}-01\end{array}$ & $\begin{array}{l}\text { KH2VAP } \\
\operatorname{Ln}(1) \\
-7.207\end{array}$ & $\begin{array}{l}\text { AYH2 } \\
\operatorname{Ln}() \\
0.1464 E-02\end{array}$ & $\begin{array}{l}\text { AH2AQ } \\
\ln () \\
0.9884 \mathrm{E}-01\end{array}$ & \\
\hline $\begin{array}{l}\text { KHCOOHVAP } \\
\mathrm{Ln}(1) \\
\quad 7.636\end{array}$ & $\begin{array}{l}\text { AYHCOOH } \\
\operatorname{Ln}() \\
-0.9508 E-02\end{array}$ & $\begin{array}{l}\text { AHCOOHAQ } \\
\text { Ln() } \\
0.9884 \mathrm{E}-01\end{array}$ & $\begin{array}{l}\text { KHEVAP } \\
\text { Ln() } \\
\quad 9.012\end{array}$ & $\begin{array}{l}\text { AYHE } \\
\operatorname{Ln}() \\
-0.62808-02\end{array}$ & $\begin{array}{l}\text { AHEAQ } \\
\text { In() } \\
0.2696\end{array}$ & \\
\hline $\begin{array}{l}\text { KHNO2VAP } \\
\operatorname{Ln}() \\
\quad 1.448\end{array}$ & $\begin{array}{l}\text { AYHNO2 } \\
\text { Ln() } \\
-0.9185 E-02\end{array}$ & $\begin{array}{l}\text { AHNO2AQ } \\
\text { Ln () } \\
0.9884 \mathrm{E}-01\end{array}$ & $\begin{array}{l}\text { KHNO 3VAP } \\
\operatorname{Ln}() \\
9.168\end{array}$ & $\begin{array}{l}\text { AYHNO3 } \\
\operatorname{Ln}() \\
-0.8389 \varepsilon-02\end{array}$ & $\begin{array}{l}\text { AHNO3AQ } \\
\operatorname{Ln}(1) \\
\quad 1.658\end{array}$ & . \\
\hline
\end{tabular}




\begin{tabular}{|c|c|c|c|c|c|}
\hline ESP $V-6.4$ & SURVE & EY-VARIABLES & & $07 / 11 /$ & 12000 \\
\hline $\begin{array}{l}\text { KN2VAP } \\
\text { Ln() } \\
-7.508\end{array}$ & $\begin{array}{l}\text { AYN2 } \\
\operatorname{Ln}() \\
0.8505 E-04\end{array}$ & $\begin{array}{l}\text { AN2AQ } \\
\text { In () } \\
0.9886 E-01\end{array}$ & $\begin{array}{l}\text { KNH } 3 \text { VAP } \\
\text { Ln() } \\
\quad 3.358\end{array}$ & $\begin{array}{l}\text { AYNH3 } \\
\text { In () } \\
-0.3824 E-02\end{array}$ & $\begin{array}{l}\text { ANH } 3 A Q \\
\operatorname{Ln}() \\
0.9884 E-01\end{array}$ \\
\hline $\begin{array}{l}\text { KNO2VAP } \\
\operatorname{Ln}() \\
-0.5411\end{array}$ & $\begin{array}{l}\text { AYNO2 } \\
\operatorname{Ln}() \\
-0.5129 E-02\end{array}$ & $\begin{array}{l}\text { ANO2AQ } \\
\operatorname{Ln}(1) \\
0.9884 E-01\end{array}$ & $\begin{array}{l}\text { KNOVAP } \\
\text { Ln() } \\
-14.27\end{array}$ & $\begin{array}{l}\text { AYNO } \\
\text { Ln }(\} \\
0.1216 E-03\end{array}$ & $\begin{array}{l}\text { ANOAQ } \\
\operatorname{In}(\} \\
0.9884 E-01\end{array}$ \\
\hline $\begin{array}{l}\text { KO2VAP } \\
\text { Ln() } \\
-6.879\end{array}$ & $\begin{array}{l}\text { AYO2 } \\
\operatorname{Ln}() \\
-0.4103 E-03\end{array}$ & $\begin{array}{l}\text { AO2AQ } \\
\operatorname{Ln}() \\
0.9884 \mathrm{E}-01\end{array}$ & $\begin{array}{l}\text { KALOH } 4 \text { ION } \\
\text { In () } \\
-16.44\end{array}$ & $\begin{array}{l}\text { AALOHAION } \\
\operatorname{Ln}() \\
-0.6511\end{array}$ & $\begin{array}{l}\text { AALOH } 3 A Q \\
\operatorname{In}() \\
0: 9884 E-01\end{array}$ \\
\hline $\begin{array}{l}\text { AOHION } \\
\operatorname{Ln}(1) \\
\quad 1.975\end{array}$ & $\begin{array}{l}\text { KALOHION } \\
\text { Ln() } \\
-20.69\end{array}$ & $\begin{array}{l}\text { AAIOHION } \\
\text { In() } \\
\quad 3.117\end{array}$ & $\begin{array}{l}\text { AALION } \\
\operatorname{Ln}() \\
\quad 3.800\end{array}$ & $\begin{array}{l}\text { KBIOH } 3 A Q \\
\operatorname{Ln}(1) \\
-74.57\end{array}$ & $\begin{array}{l}\text { ABIOH } 3 A Q \\
\text { In () } \\
0.9884 E-01\end{array}$ \\
\hline $\begin{array}{l}\text { ABIION } \\
\text { In () } \\
\quad 4.112\end{array}$ & $\begin{array}{l}\text { KBIOH } 4 \text { ION } \\
\text { Ln() } \\
-2.945\end{array}$ & $\begin{array}{l}\text { ABIOH } 4 \text { ION } \\
\text { Ln() } \\
-0.9454\end{array}$ & $\begin{array}{l}\text { KCA5OHPO } 3 \text { PE } \\
\operatorname{Ln}() \\
-12.65^{\circ}\end{array}$ & $\begin{array}{l}\text { PACAION } \\
\text { In (1) } \\
-3.428\end{array}$ & $\begin{array}{l}\text { APO } 4 \text { ION } \\
\text { In () } \\
-5.940\end{array}$ \\
\hline $\begin{array}{l}\text { KCAACET } 2 A Q \\
\operatorname{Ln}() \\
-4.890\end{array}$ & $\begin{array}{l}\text { ACAACET } 2 A Q \\
\operatorname{Ln}() \\
0.9884 \mathrm{E}-01\end{array}$ & $\begin{array}{l}\text { AACETATEION } \\
\text { Ln (1) } \\
0.3730\end{array}$ & $\begin{array}{l}\text { KCAACETION } \\
\text { Ln() } \\
\quad-2.218\end{array}$ & $\begin{array}{l}\text { ACAACETION } \\
\text { In () } \\
0.2198\end{array}$ & $\begin{array}{l}\text { KCAC204AQ } \\
\operatorname{Ln}() \\
-8.217\end{array}$ \\
\hline $\begin{array}{l}A C A C 204 A Q \\
\operatorname{Ln}() \\
0.9884 \mathrm{E}-01\end{array}$ & $\begin{array}{l}\text { AOXALATION } \\
\text { Ln () } \\
-3.835\end{array}$ & $\begin{array}{l}\text { KCACO3AQ } \\
\operatorname{Ln}() \\
-7.994\end{array}$ & $\begin{array}{l}\text { ACACO } 3 A Q \\
\operatorname{In}() \\
0.9884 \mathrm{E}-01\end{array}$ & $\begin{array}{l}\text { ACO3ION } \\
\operatorname{Ln}() \\
-3.708\end{array}$ & $\begin{array}{l}\text { KCACOOH } 2 A Q \\
\text { Ln () } \\
-1.924\end{array}$ \\
\hline $\begin{array}{l}\text { ACACOOH } 2 A Q \\
\operatorname{Ln}() \\
0.9884 \mathrm{E}-01\end{array}$ & $\begin{array}{l}\text { ACACOOHION } \\
\text { Ln() } \\
0.2194\end{array}$ & $\begin{array}{l}\text { ACOOHION } \\
\text { In () } \\
0.6814\end{array}$ & $\begin{array}{l}\text { KCACOOHION } \\
\text { In () } \\
-3.268\end{array}$ & $\begin{array}{l}\text { KCACTRTION } \\
\operatorname{Ln}(1) \\
-10.76\end{array}$ & $\begin{array}{l}\text { ACACTRTION } \\
\operatorname{Ln}() \\
-0.9454\end{array}$ \\
\hline
\end{tabular}




\begin{tabular}{|c|c|c|c|c|c|}
\hline ESP V-6.4 & SURVE & EY-VARIABLES & & $07 / 11$ & PAGE = \\
\hline $\begin{array}{l}\text { ACITRATION } \\
\text { Ln(1) } \\
-2.935\end{array}$ & $\begin{array}{l}\text { KCAEDTAION } \\
\text { In () } \\
-28.04\end{array}$ & $\begin{array}{l}\text { ACAEDTAION } \\
\text { Ln(1) } \\
-3.782\end{array}$ & $\begin{array}{l}\text { AEDTAION } \\
\text { In (1) } \\
-8.534\end{array}$ & $\begin{array}{l}\text { KCAFION } \\
\ln (1) \\
\quad 1.631\end{array}$ & $\begin{array}{l}\text { ACAEION } \\
\operatorname{Ln}(1) \\
0.2198\end{array}$ \\
\hline $\begin{array}{l}\text { AEION } \\
\operatorname{Ln}(1) \\
-0.1974\end{array}$ & $\begin{array}{l}\text { KCAGLYCOL } 2 A C \\
\operatorname{Ln}(1) \\
-5.285\end{array}$ & $\begin{array}{l}\text { QACAGLYCOL2A } \\
\operatorname{Ln}(1) \\
0.9884 \mathrm{E}-01\end{array}$ & $\begin{array}{l}\text { QAGLYCOLATIO } \\
\text { Ln(1) } \\
0.5779\end{array}$ & $\begin{array}{l}\text { NKCAGLYCOLIO) } \\
\text { In () } \\
-3.150\end{array}$ & $\begin{array}{l}\text { NACAGLYCOLION } \\
\operatorname{Ln}() \\
0.2194\end{array}$ \\
\hline $\begin{array}{l}\text { KCAH2SIO4AQ } \\
\operatorname{Ln}() \\
-10.93\end{array}$ & $\begin{array}{l}\text { ACAH2SIO4AQ } \\
\text { Ln() } \\
0.9884 E-01\end{array}$ & $\begin{array}{l}\text { AH2SIO4 ION } \\
\text { Ln (1) } \\
\quad 12.47\end{array}$ & $\begin{array}{l}\text { KCAHC2O42AQ } \\
\text { Ln() } \\
-5.649\end{array}$ & $\begin{array}{l}\text { ACAHC2O42AQ } \\
\operatorname{Ln}() \\
0.9884 \mathrm{E}-01\end{array}$ & $\begin{array}{l}\text { AHOXALATION } \\
\text { Ln() } \\
0.5779\end{array}$ \\
\hline $\begin{array}{l}\text { KCANO3ION } \\
\text { In() } \\
-1.037\end{array}$ & $\begin{array}{l}\text { ACANO3ION } \\
\text { Ln() } \\
15.31\end{array}$ & $\begin{array}{l}\text { ANO3ION } \\
\operatorname{Ln}() \\
-0.4793\end{array}$ & $\begin{array}{l}\text { KCAOH2PPT } \\
\text { Ln() } \\
-12.86\end{array}$ & $\begin{array}{l}\text { KCAOHION } \\
\text { Ln() } \\
-3.077\end{array}$ & $\begin{array}{l}\text { ACAOHION } \\
\text { In () } \\
0.3953\end{array}$ \\
\hline $\begin{array}{l}\text { KCAPO4 ION } \\
\text { Ln() } \\
-15.58\end{array}$ & $\begin{array}{l}\text { ACAPO4ION } \\
\operatorname{Ln}() \\
-0.9454\end{array}$ & $\begin{array}{l}\text { KCASEO } 3.2 \mathrm{H} 2 \\
\operatorname{Ln}() \\
-1 \pm .32\end{array}$ & $\begin{array}{l}\text { DASEO3ION } \\
\text { Ln() } \\
-3.835\end{array}$ & $\begin{array}{l}\text { KCASO4AQ } \\
\operatorname{Ln}(1) \\
-4.990\end{array}$ & $\begin{array}{l}\text { ACASO4AQ } \\
\operatorname{In}() \\
0.9884 E-01\end{array}$ \\
\hline $\begin{array}{l}\text { ASO4ION } \\
\text { Ln() } \\
-5.729\end{array}$ & $\begin{array}{l}\text { KAGCL2ION } \\
\text { Ln() } \\
-11.46\end{array}$ & $\begin{array}{l}\text { AAGCL2ION } \\
\operatorname{Ln}() \\
-0.9454\end{array}$ & $\begin{array}{l}\text { AAGION } \\
\text { Ln(1) } \\
0.3954\end{array}$ & $\begin{array}{l}\text { ACLION } \\
\text { Ln() } \\
0.5367\end{array}$ & $\begin{array}{l}\mathrm{KCO} 2 \mathrm{AQ} \\
\operatorname{Ln}(1) \\
-14.47\end{array}$ \\
\hline $\begin{array}{l}\text { AHION } \\
\operatorname{Ln}() \\
-0.4423\end{array}$ & $\begin{array}{l}\text { AHCO3ION } \\
\operatorname{Ln}() \\
-0.5973\end{array}$ & $\begin{array}{l}\text { KAGC204ION } \\
\operatorname{Ln}(1) \\
-7.129\end{array}$ & $\begin{array}{l}\text { AAGC204ION } \\
\operatorname{Ln}(1) \\
-0.9454\end{array}$ & $\begin{array}{l}\text { KCSACETAQ } \\
\text { In () } \\
-0.1941\end{array}$ & $\begin{array}{l}\text { ACSACETAQ } \\
\text { In () } \\
0.9884 \mathrm{E}-01\end{array}$ \\
\hline $\begin{array}{l}\text { ACSION } \\
\text { Ln () } \\
\quad 2.896\end{array}$ & $\begin{array}{l}\text { KCSCLAQ } \\
\text { In () } \\
0.6936\end{array}$ & $\begin{array}{l}\text { ACSCLAQ } \\
\operatorname{Ln}() \\
0.9884 E-01\end{array}$ & $\begin{array}{l}\text { KCSCTRTION } \\
\text { Ln() } \\
-2.199\end{array}$ & $\begin{array}{l}\text { ACSCTRTION } \\
\operatorname{Ln(1)} \\
-3.782\end{array}$ & $\begin{array}{l}\text { KCSGLYCOL2ION } \\
\text { Ln() } \\
-0.1401\end{array}$ \\
\hline
\end{tabular}




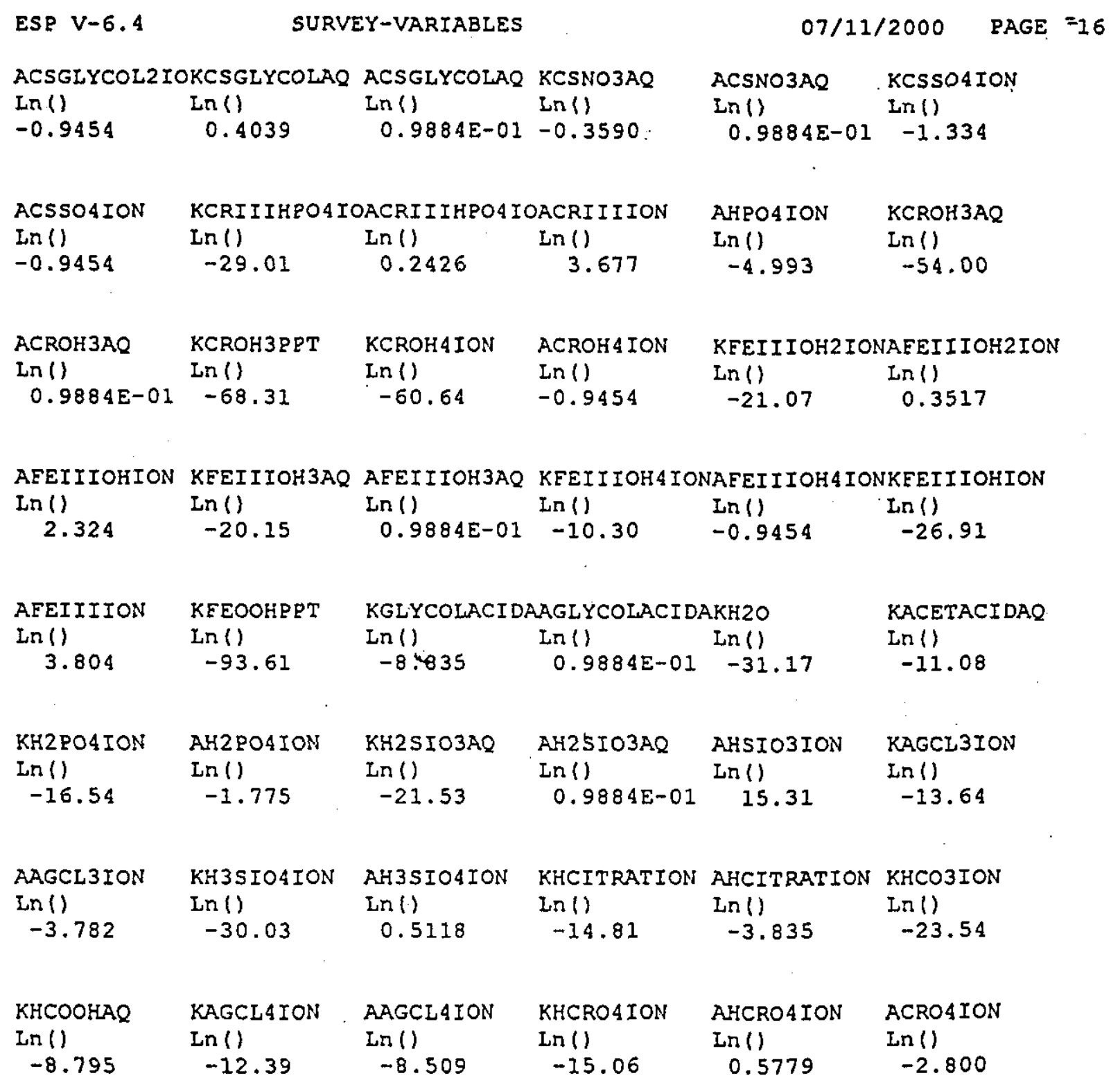




\begin{tabular}{|c|c|c|c|c|c|c|}
\hline ESP $V-6.4$ & SURV & EY-VARIABLES & & $07 / 11 /$ & $/ 2000$ & $=17$ \\
\hline $\begin{array}{l}\text { KHEDTAION } \\
\text { Ln }(1 \\
-26.00\end{array}$ & $\begin{array}{l}\text { AHEDTAION } \\
\text { Ln(1) } \\
-2.935\end{array}$ & $\begin{array}{l}\text { KHSEO3ION } \\
\operatorname{Ln}(1) \\
-16.72\end{array}$ & $\begin{array}{l}\text { AHSEO3ION } \\
\operatorname{Ln}(1) \\
0.5779:\end{array}$ & $\begin{array}{l}\text { KHEAQ } \\
\operatorname{Ln}() \\
-7.553\end{array}$ & $\begin{array}{l}\text { KAGCIAQ } \\
\operatorname{Ln}(1) \\
-7.327\end{array}$ & \\
\hline $\begin{array}{l}\text { AAGCLAQ } \\
\text { In () } \\
0.9884 \mathrm{E}-01\end{array}$ & $\begin{array}{l}\text { KHGCL2AQ } \\
\operatorname{Ln}(1) \\
-31.13\end{array}$ & $\begin{array}{l}\text { AHGCL2AQ } \\
\text { In () } \\
0.9884 E-01\end{array}$ & $\begin{array}{l}\text { AHGION } \\
\operatorname{Ln}() \\
\quad 1.988\end{array}$ & $\begin{array}{l}\text { KHGCL3ION } \\
\text { Ln (1) } \\
-33.28\end{array}$ & $\begin{array}{l}\text { AHGCL3ION } \\
\operatorname{Ln}() \\
-0.9454\end{array}$ & \\
\hline $\begin{array}{l}\text { KHGCL } 4 \text { ION } \\
\text { In() } \\
-34.67\end{array}$ & $\begin{array}{l}\text { AHGCL } 4 \text { ION } \\
\text { Ln() } \\
-3.782\end{array}$ & $\begin{array}{l}\text { KHGEDTAION } \\
\text { Ln () } \\
-54.37\end{array}$ & $\begin{array}{l}\text { AHGEDTAION } \\
\operatorname{Ln}(1) \\
-3.782\end{array}$ & $\begin{array}{l}\text { KHGNH } 32 \text { ION } \\
\text { In () } \\
-38.44\end{array}$ & $\begin{array}{l}\text { AHGNH32ION } \\
\text { In () } \\
1.791\end{array}$ & \\
\hline $\begin{array}{l}\text { KHGNH33ION } \\
\text { In () } \\
-40.40\end{array}$ & $\begin{array}{l}\text { AHGNH33ION } \\
\operatorname{Ln}() \\
1.791\end{array}$ & $\begin{array}{l}\text { KHGNH34ION } \\
\text { In () } \\
-42.00\end{array}$ & $\begin{array}{l}\text { AHGNH34ION } \\
\text { Ln () } \\
1.791\end{array}$ & $\begin{array}{l}\text { KHGOH2AQ } \\
\operatorname{Ln}(1) \\
-48.89\end{array}$ & $\begin{array}{l}\text { AHGOH2AQ } \\
\operatorname{In}() \\
0.9884 \mathrm{E}-01\end{array}$ & \\
\hline $\begin{array}{l}\text { KHGOH3ION } \\
\operatorname{Ln}(1) \\
-46.68\end{array}$ & $\begin{array}{l}\text { AHGOH3ION } \\
\text { Ln() } \\
-0.9454\end{array}$ & $\begin{array}{l}\text { KHNO2AQ } \\
\text { Ln () } \\
-7.142\end{array}$ & $\begin{array}{l}\text { ANO2ION } \\
\operatorname{In}() \\
\quad 1.153\end{array}$ & $\begin{array}{l}\text { KAGNO22ION } \\
\text { Ln() } \\
-8.338\end{array}$ & $\begin{array}{l}\text { AAGNO22ION } \\
\operatorname{In}(1) \\
-0.9454\end{array}$ & \\
\hline $\begin{array}{l}\text { KHNO3AQ } \\
\operatorname{Ln}(1) \\
\quad 2.652\end{array}$ & $\begin{array}{l}\text { KAGNO2AQ } \\
\text { In() } \\
-5.111\end{array}$ & $\begin{array}{l}\text { AAGNO2AQ } \\
\text { In () } \\
0.9884 E-01\end{array}$ & $\begin{array}{l}\text { KHOXALATION } \\
\text { Ln() } \\
-9.988\end{array}$ & $\begin{array}{l}\text { KHP207ION } \\
\operatorname{Ln}(1) \\
-21.40\end{array}$ & $\begin{array}{l}\text { AHP207ION } \\
\text { In () } \\
-2.911\end{array}$ & \\
\hline $\begin{array}{l}\text { AP207ION } \\
\text { moles } \\
\quad 55.66\end{array}$ & $\begin{array}{l}\text { KHPBO2ION } \\
\operatorname{Ln}(1) \\
-6.733\end{array}$ & $\begin{array}{l}\text { AHPBO2ION } \\
\operatorname{Ln}() \\
0.5118\end{array}$ & $\begin{array}{l}\text { APBOAQ } \\
\text { In () } \\
0.9884 E-0 I\end{array}$ & $\begin{array}{l}\text { KHPO } 4 \text { ION } \\
\operatorname{In}(1) \\
-28.13\end{array}$ & $\begin{array}{l}\text { KHSIO3ION } \\
\text { Ln() } \\
-27.27\end{array}$ & \\
\hline $\begin{array}{l}\text { ASIO3ION } \\
\text { In () } \\
\quad 12.47\end{array}$ & $\begin{array}{l}\text { KKACETAQ } \\
\operatorname{Ln}() \\
0.4791\end{array}$ & $\begin{array}{l}\text { AKACETAQ } \\
\text { In () } \\
0.9884 \mathrm{E}-01\end{array}$ & $\begin{array}{l}\text { AKION } \\
\operatorname{Ln}() \\
\quad 0.9229\end{array}$ & $\begin{array}{l}\text { KKALS IO4 PPT } \\
\operatorname{Ln}(1) \\
\quad 21.56\end{array}$ & $\begin{array}{l}\text { ASIO2AQ } \\
\operatorname{Ln}(1) \\
0.9884 E-01\end{array}$ & \\
\hline
\end{tabular}




\begin{tabular}{|c|c|c|c|c|c|}
\hline ESP V-6.4 & \multicolumn{3}{|c|}{ SURVEY-VARIABLES } & $07 / 11 / 2000$ & PAGE $=18$ \\
\hline $\begin{array}{l}\text { KKCOOHLAQ } \\
\text { Ln () } \\
-0.1314\end{array}$ & $\begin{array}{l}\text { AKCOOHAQ } \\
\text { In () } \\
0.9884 E-01\end{array}$ & $\begin{array}{l}\text { KKCLAQ } \\
\operatorname{In}() \\
\quad 4.443\end{array}$ & $\begin{array}{l}\text { AKCLAQ } \\
\text { In () } \\
0.9884 E-01\end{array}$ & $\begin{array}{l}\text { KKCTRTION } \\
\operatorname{Ln}() \\
-2.818\end{array}$ & $\begin{array}{l}\text { AKCTRTION } \\
\operatorname{Ln}(1) \\
-3.784\end{array}$ \\
\hline $\begin{array}{l}\text { KKEDTAION } \\
\text { Ln() } \\
-3.810\end{array}$ & $\begin{array}{l}\text { AKEDTAION } \\
\text { Ln () } \\
-8.267\end{array}$ & $\begin{array}{l}\text { KKGLYCOL2 ION } \\
\operatorname{In}() \\
\quad 1.443\end{array}$ & $\begin{array}{l}\text { NAKGLYCOL2ION } \\
\text { Ln() } \\
-0.8793\end{array}$ & $\begin{array}{l}\text { JKKGLYCOLATAQ } \\
\text { Ln() } \\
0.4782\end{array}$ & $\begin{array}{l}\text { QAKGLYCOLATAQ } \\
\operatorname{Ln}() \\
0.9884 \mathrm{E}-01\end{array}$ \\
\hline $\begin{array}{l}\text { KKSO4ION } \\
\text { Ln() } \\
-2.111\end{array}$ & $\begin{array}{l}\text { AKSO4 ION } \\
\text { Ln() } \\
-0.8793\end{array}$ & $\begin{array}{l}\text { KKTCVIIO4PPT } \\
\text { In() } \\
\quad-4.206\end{array}$ & $\begin{array}{l}\text { TATCVIIO4ION } \\
\operatorname{Ln}(1) \\
\quad 15.31\end{array}$ & $\begin{array}{l}\text { KMNC2O4AQ } \\
\operatorname{Ln}(1) \\
-14.65\end{array}$ & $\begin{array}{l}\text { AMNC204AQ } \\
\text { In () } \\
0.9884 E-01\end{array}$ \\
\hline $\begin{array}{l}\text { AMNION } \\
\operatorname{Ln}() \\
-7.278\end{array}$ & $\begin{array}{l}\text { KMNCLION } \\
\operatorname{Ln}(1) \\
-1.528\end{array}$ & $\begin{array}{l}\text { AMNCLION } \\
\operatorname{Ln}() \\
0.2659\end{array}$ & $\begin{array}{l}\text { KMNEDTAION } \\
\text { In () } \\
-35.64\end{array}$ & $\begin{array}{l}\text { ANDEDTAION } \\
\text { In () } \\
-3.782\end{array}$ & $\begin{array}{l}\text { KMNNO32AQ } \\
\operatorname{Ln}(1) \\
-1.688\end{array}$ \\
\hline $\begin{array}{l}\text { AMNNO32AQ } \\
\operatorname{Ln}() \\
0.9884 \mathrm{E}-01\end{array}$ & $\begin{array}{l}\text { KMNSO } 4 A Q \\
\text { Ln() } \\
-5.620\end{array}$ & $\begin{array}{l}\text { AMNSO } 4 A Q \\
\operatorname{Ln}() \\
0.9884 \mathrm{E}-01\end{array}$ & $\begin{array}{l}\text { KAGOH2ION } \\
\operatorname{Ln}() \\
-9.038\end{array}$ & $\begin{array}{l}\text { AAGOH2 ION } \\
\operatorname{Ln}() \\
-0.9454\end{array}$ & $\begin{array}{l}\text { KNA2 EION } \\
\operatorname{Ln}() \\
\quad 4.304\end{array}$ \\
\hline $\begin{array}{l}\text { ANA2EION } \\
\operatorname{In}() \cdot \\
15.31\end{array}$ & $\begin{array}{l}\text { ANAION } \\
\text { In () } \\
\quad 1.496\end{array}$ & $\begin{array}{l}\text { ANAEAQ } \\
\operatorname{Ln}() \\
0.9884 \mathrm{E}-01\end{array}$ & $\begin{array}{l}\text { KNA2SEO3.5H2 } \\
\operatorname{Ln}() \\
-0.4193\end{array}$ & $\begin{array}{l}\text { KNA2 SEO3PPT } \\
\text { In () } \\
0.6711\end{array}$ & $\begin{array}{l}\text { KNA2 SEO4.10H2O } \\
\operatorname{Ln}(1) \\
-1.384\end{array}$ \\
\hline $\begin{array}{l}\text { ASEO4ION } \\
\text { In () } \\
-3.835\end{array}$ & $\begin{array}{l}\text { KNA2 SEO4PPT } \\
\text { Ln() } \\
0.5175 E-01\end{array}$ & $\begin{array}{l}\text { KNA2U207PPT } \\
\operatorname{In}() \\
-44.80\end{array}$ & $\begin{array}{l}\text { AUO2 ION } \\
\text { Ln () } \\
\quad 2.212\end{array}$ & $\begin{array}{l}\text { KNA6SO } 2 \text { CO3E } \\
\operatorname{Ln()} \\
-6.809 .\end{array}$ & $\begin{array}{l}\text { PKNAACETAQ } \\
\text { Ln() } \\
0.2016\end{array}$ \\
\hline $\begin{array}{l}\text { ANAACETAQ } \\
\text { Ln () } \\
0.9884 E-01\end{array}$ & $\begin{array}{l}\text { KNAALO22.2.5 } \\
\operatorname{Ln}(1) \\
\quad 8.988\end{array}$ & $\begin{array}{l}\text { 5KNAALSIO4 PPT } \\
\text { Ln() } \\
27.73\end{array}$ & $\begin{array}{l}\text { TKNACO3ION } \\
\text { In () } \\
-0.9310\end{array}$ & $\begin{array}{l}\text { ANACO3ION } \\
\text { In () } \\
0.5118\end{array}$ & $\begin{array}{l}\text { KNACOOHAQ } \\
\operatorname{Ln}() \\
-0.1055\end{array}$ \\
\hline
\end{tabular}




\begin{tabular}{|c|c|c|c|c|c|c|}
\hline ESP V-6.4 & SURV & EY-VARIABLES & & $07 / 11$ & 12000 & $=19$ \\
\hline $\begin{array}{l}\text { ANACOOHAQ } \\
\operatorname{In}() \\
0.9884 \mathrm{E}-01\end{array}$ & $\begin{array}{l}\text { KNACTRTION } \\
\operatorname{Ln}() \\
-3.106\end{array}$ & $\begin{array}{l}\text { ANACTRTION } \\
\text { Ln () } \\
-3.833\end{array}$ & $\begin{array}{l}\text { KNAEDTAION } \\
\text { Ln() } \\
-5.859\end{array}$ & $\begin{array}{l}\text { ANAEDTAION } \\
\text { In () } \\
-3.177\end{array}$ & $\begin{array}{l}\text { KNAEAQ } \\
\operatorname{In}() \\
0.2960\end{array}$ & \\
\hline $\begin{array}{l}\text { KNAGLYCOLAT } \\
\text { In () } \\
0.5042\end{array}$ & $\begin{array}{l}\text { AANAGLYCOLAT } \\
\operatorname{In}() \\
\quad 0.9884 \mathrm{E}-01\end{array}$ & $\begin{array}{l}\text { AKNAHCO } 3 A Q \\
\operatorname{Ln}(1) \\
0.5486\end{array}$ & $\begin{array}{l}\text { ANAHCO } 3 A Q \\
\text { Ln() } \\
0.9884 \mathrm{E}-01\end{array}$ & $\begin{array}{l}\text { KNAHSIO3AQ } \\
\text { In () } \\
-3.807\end{array}$ & $\begin{array}{l}\text { ANAHSIO3AQ } \\
\text { Ln() } \\
0.9884 \mathrm{E}-01\end{array}$ & \\
\hline $\begin{array}{l}\text { KNANO2AQ } \\
\operatorname{In}(1) \\
\quad 1.967\end{array}$ & $\begin{array}{l}\text { ANANO2AQ } \\
\text { Ln () } \\
0.8150\end{array}$ & $\begin{array}{l}\text { KNANO } 3 A Q \\
\operatorname{Ln}(1) \\
1.355\end{array}$ & $\begin{array}{l}\text { ANANO3AQ } \\
\text { Ln() } \\
0.6118\end{array}$ & $\begin{array}{l}\text { KNANO3PPT } \\
\text { In () } \\
2.861 .\end{array}$ & $\begin{array}{l}\text { KNASO } 4 \text { ION } \\
\text { Ln() } \\
-0.1900\end{array}$ & \\
\hline $\begin{array}{l}\text { ANASO4ION } \\
\operatorname{Ln}() \\
-0.1555\end{array}$ & $\begin{array}{l}\text { KNATCVIIO4P } \\
\text { Ln() } \\
\quad 3.993\end{array}$ & $\begin{array}{l}\text { PKNH2CO2ION } \\
\operatorname{Ln}() \\
-0.4023\end{array}$ & $\begin{array}{l}\text { ANH2CO2ION } \\
\operatorname{Ln}(1) \\
0.5367\end{array}$ & $\begin{array}{l}\text { KNH } 3 A Q \\
\operatorname{Ln}(1) \\
-10.90\end{array}$ & $\begin{array}{l}\text { ANH4ION } \\
\text { Ln() } \\
0.1057\end{array}$ & \\
\hline $\begin{array}{l}\text { KAGOHAQ } \\
\text { In () } \\
-4.595\end{array}$ & $\begin{array}{l}\text { AAGOHAQ } \\
\text { Ln() } \\
0.9884 \mathrm{E}-01\end{array}$ & $\begin{array}{l}\text { KNH } 4 \text { ACETAQ } \\
\operatorname{Ln}() \\
-0 . \$ 909\end{array}$ & $\begin{array}{l}\text { ANH } 4 A C E T A Q \\
\text { Ln () } \\
0.9884 E-01\end{array}$ & $\begin{array}{l}\text { KNH 4NO3AQ } \\
\operatorname{Ln}() \\
-2.167\end{array}$ & $\begin{array}{l}\text { ANH 4NO3AQ } \\
\text { Ln () } \\
0.9884 \mathrm{E}-01\end{array}$ & \\
\hline $\begin{array}{l}\text { KNH } 4 \text { SO } 4 \text { ION } \\
\operatorname{In}() \\
-2.630\end{array}$ & $\begin{array}{l}\text { ANH4 SO4 ION } \\
\text { In () } \\
-0.9454\end{array}$ & $\begin{array}{l}\text { KNIACETION } \\
\text { In () } \\
-3.145\end{array}$ & $\begin{array}{l}\text { ANIACETION } \\
\text { In }() \\
0.2199\end{array}$ & $\begin{array}{l}\text { ANIION } \\
\operatorname{In}(1) \\
-6.552\end{array}$ & $\begin{array}{l}\text { KNIC2042ION } \\
\operatorname{Ln}() \\
\quad-17.61\end{array}$ & \\
\hline $\begin{array}{l}\text { ANIC2042ION } \\
\operatorname{Ln}() \\
-3.782\end{array}$ & $\begin{array}{l}\text { KNIC2O4AQ } \\
\operatorname{Ln}(1) \\
-17.36\end{array}$ & $\begin{array}{l}\text { ANIC204AQ } \\
\operatorname{Ln}() \\
0.9884 \mathrm{E}-01\end{array}$ & $\begin{array}{l}\text { KNICTRTION } \\
\text { LN () } \\
\quad-14.71\end{array}$ & $\begin{array}{l}\text { ANICTRTION } \\
\text { Ln () } \\
-0.9454\end{array}$ & $\begin{array}{l}\text { KNIEDTAION } \\
\text { In () } \\
-46.21\end{array}$ & \\
\hline $\begin{array}{l}\text { ANIEDTAION } \\
\operatorname{Ln}() \\
-3.782\end{array}$ & $\begin{array}{l}\text { KNINH32ION } \\
\operatorname{In}(1) \\
-10.64\end{array}$ & $\begin{array}{l}\text { ANINH32ION } \\
\text { In }() \\
1.791\end{array}$ & $\begin{array}{l}\text { KNINH33ION } \\
\text { In }\{\} \\
-14.12\end{array}$ & $\begin{array}{l}\text { ANINH } 33 \text { ION } \\
\text { In (1) } \\
1.791\end{array}$ & $\begin{array}{l}\text { KNINH3ION } \\
\operatorname{Ln}() \\
-5.956\end{array}$ & \\
\hline
\end{tabular}




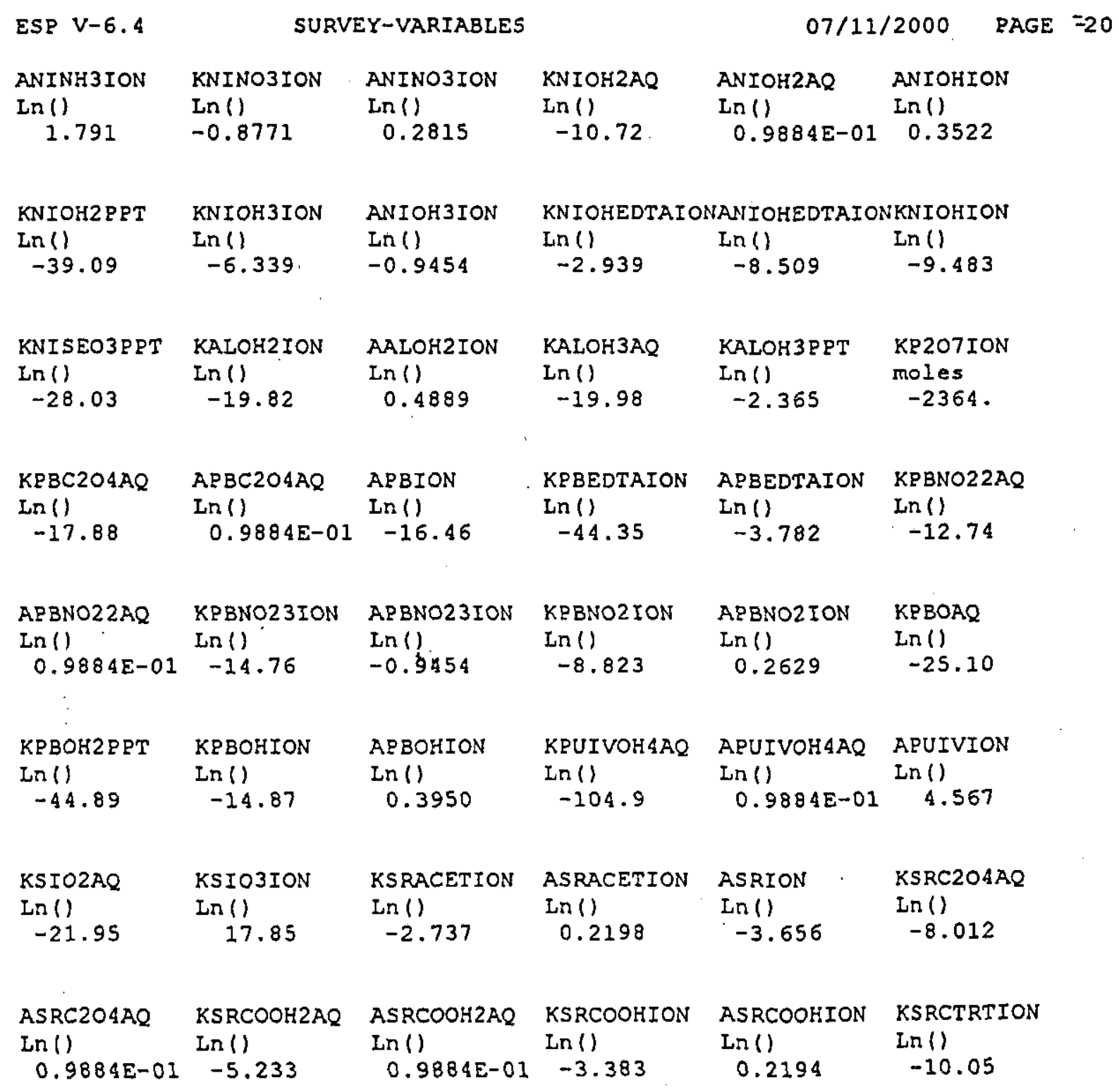




\section{RPP 5643 REV 0}

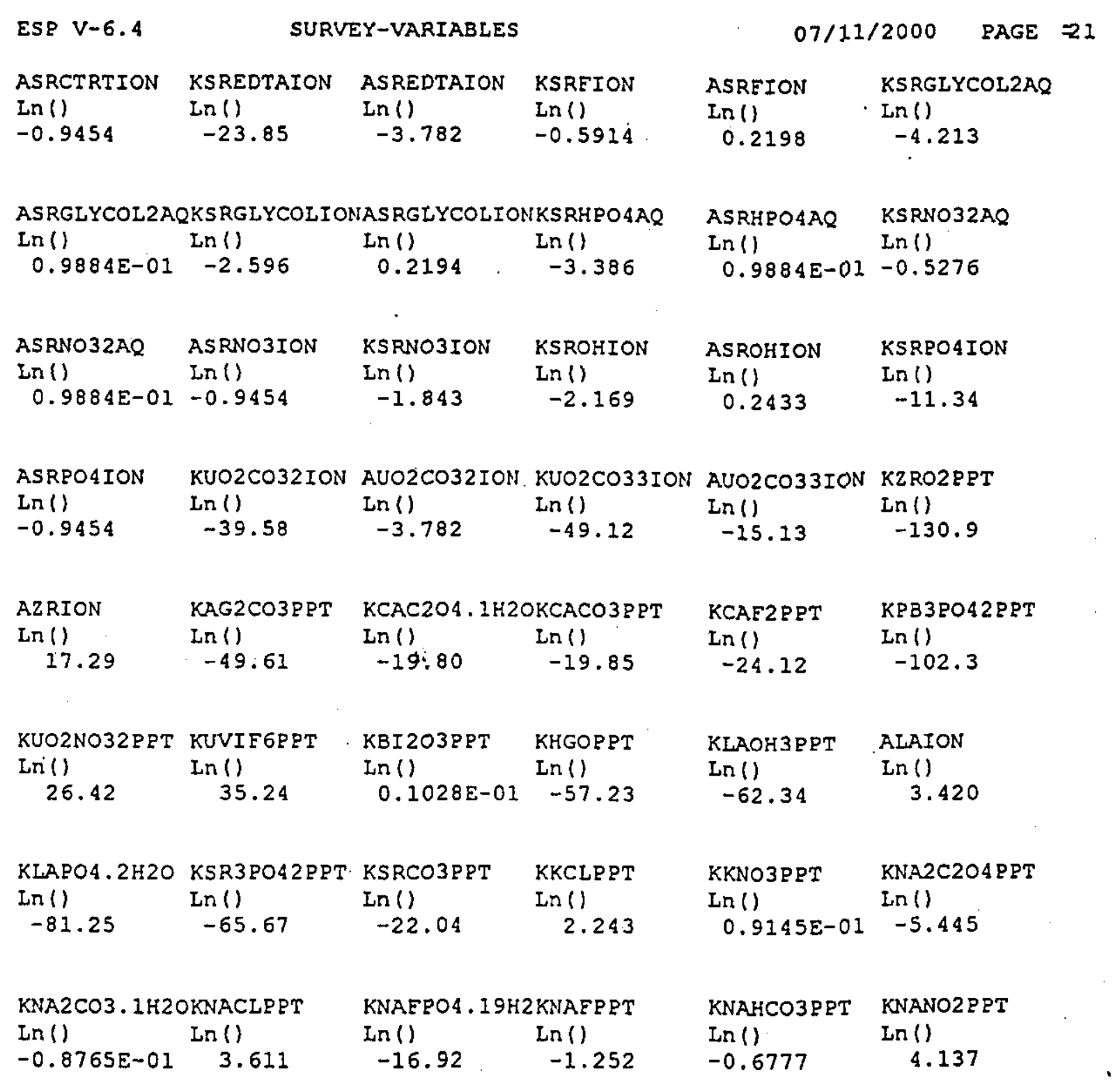




\begin{tabular}{|c|c|c|c|c|c|}
\hline ESP V-6.4 & \multicolumn{2}{|c|}{ SURVEY-VARIABLES } & \multicolumn{3}{|c|}{$07 / 11 / 2000$} \\
\hline $\begin{array}{l}\text { KNAPHOH } .12 \mathrm{H} \\
\operatorname{Ln}() \\
-5.657\end{array}$ & $\begin{array}{l}\text { KPUIVOH } 4 \text { PPT } \\
\operatorname{Ln}() \\
-126.2\end{array}$ & $\begin{array}{l}\text { KNA3FSO4PRT } \\
\text { Ln() } \\
-5.757\end{array}$ & $\begin{array}{l}\text { KCR203PPT } \\
\text { In() } \\
-16.65\end{array}$ & $\begin{array}{l}\text { KMNO2 PPT } \\
\operatorname{Ln}(1) \\
-65.50\end{array}$ & $\begin{array}{l}\text { KSEO4ION } \\
\text { In () } \\
-6.103\end{array}$ \\
\hline $\begin{array}{l}\text { KCRIIIION } \\
\text { In () } \\
-8.488\end{array}$ & $\begin{array}{l}\mathrm{KH} 2 \mathrm{AQ} \\
\mathrm{Ln}() \\
20.16\end{array}$ & $\begin{array}{l}\text { KNOAQ } \\
\operatorname{Ln}() \\
\quad 15.43\end{array}$ & $\begin{array}{l}\text { KNO2ION } \\
\text { Ln () } \\
\quad 14.87\end{array}$ & $\begin{array}{l}\text { KNO2AQ } \\
\mathrm{Ln}() \\
18.34\end{array}$ & 15.88 \\
\hline $\begin{array}{r}\text { DENSITY } \\
\mathrm{mol} / \mathrm{gal} \\
236.3\end{array}$ & $\begin{array}{l}\text { ZCOMP } \\
0.9999\end{array}$ & $\begin{array}{l}\text { VOLVAP } \\
\text { gal/hr } \\
1.761\end{array}$ & $\begin{array}{l}\text { VAP FLOW (MOL) } \\
\text { mol/hr } \\
0.2577\end{array}$ & $\begin{array}{l}\text { VOLSOL } \\
\text { gal/hr } \\
5.015\end{array}$ & $\begin{array}{l}\text { VOLLIQ } \\
\text { gal/hr } \\
18.24\end{array}$ \\
\hline $\begin{array}{r}\text { DENSITY } \\
\mathrm{mol} / \mathrm{gal} \\
236.3\end{array}$ & $\begin{array}{l}\text { OSPRES } \\
\text { mmHg } \\
\quad 0.1396 E+07\end{array}$ & $\begin{array}{l}\text { ORP } \\
\text { volts } \\
-0.1636\end{array}$ & $\begin{array}{l}\text { ECOND } \\
1 / 0 \mathrm{hm} / \mathrm{cm} \\
0.3335\end{array}$ & $\begin{array}{l}\text { ECONDM } \\
\mathrm{cm} 2 / 0 \mathrm{hm} / \\
10.03\end{array}$ & $\begin{array}{l}\text { VISABS } \\
7.804\end{array}$ \\
\hline $\begin{array}{l}\text { VISREL } \\
\qquad 11.94\end{array}$ & $\begin{array}{l}\text { D_H2O } \\
0.2512 \mathrm{E}-15\end{array}$ & $\begin{array}{l}\text { D CH4AQ } \\
\text { moles } \\
0.5580 E-14\end{array}$ & $\begin{array}{l}\text { D_CO2AQ } \\
\text { moles } \\
\quad 0.7066 \mathrm{E}-14\end{array}$ & $\begin{array}{l}\text { D_ACETACIDAC } \\
\text { moles } \\
0.8604 E-14\end{array}$ & $\begin{array}{l}\text { QD_H2AQ } \\
\text { moles } \\
\quad 0.1993 \mathrm{E}-13\end{array}$ \\
\hline $\begin{array}{l}\text { D_ZRION } \\
\text { moles } \\
0.2320 \mathrm{E}-14\end{array}$ & $\begin{array}{l}\text { VOL } \\
\text { gal/hr } \\
25.02\end{array}$ & & . & & \\
\hline
\end{tabular}


RPP-5643 REV 0

APPENDIX D

BOUNDARY CONDITIONS - VENTILATION INLET NOMINAL TEMPERATURE AND ABSOLUTE HUMIDITY

D-i 
RPP-5643 REV 0

This page intentionally left blank.

D-ii 


\section{APPENDIX D \\ BOUNDARY CONDITIONS - VENTILATION INLET NOMINAL TEMPERATURE AND ABSOLUTE HUMIDITY}

Because the thermal time constant for a tank full of waste is on the order of two weeks, it is appropriate to use inlet air temperatures (dry-bulb) averaged over each month as an inlet condition. Monthly average temperatures for the Hanford Site from 1945 through 1999 are provided in Table 3.1 of the Climatological Data Summary, 1993, with Historical Data (PNL-9809). The model monthly average temperatures were derived as an average of the temperatures for each month plus two standard deviations (Table D-1). The table also shows the record monthly average temperatures and the year the record occurred. The record temperatures for March, May, June, July, August, September, and October exceed the modeled temperatures. All but one year (1990) contained only one record month. Two record hot months occurred in 1990. The data in PNL-9809 also show that two years (1985 and 1955) contained both record high and record low monthly average temperatures. It was therefore, concluded that the modeled temperatures represent a conservatively hot year.

Table D-1. Monthly Average Temperature for Heat Removal Analysis.

\begin{tabular}{|c|c|c|c|}
\hline Month & $\begin{array}{l}\text { Modeled Monthly } \\
\text { Temperature }\left({ }^{\circ} \mathbf{F}\right)\end{array}$ & $\begin{array}{l}\text { Record Monthly } \\
\text { Average } \\
\text { Temperature ( F) }\end{array}$ & $\begin{array}{l}\text { Year of Record } \\
\text { Monthly Average } \\
\text { Temperature }\end{array}$ \\
\hline January & 44.0 & 42.5 & 1953 \\
\hline February & 46.2 & 44.5 & 1958 \\
\hline March & 50.4 & 51.5 & 1992 \\
\hline April & 58.3 & 58.2 & 1994 \\
\hline May & 68.0 & 68.7 & 1947 \\
\hline June & 75.2 & 76.8 & 1992 \\
\hline July & 82.0 & 82.2 & 1985 \\
\hline August & 80.7 & 81.5 & 1967 \\
\hline September & 72.2 & 72.4 & 1990 \\
\hline October & 57.5 & 59.6 & 1988 \\
\hline November & 48.3 & 46.5 & 1990 \\
\hline December & 40.7 & 38.5 & 1957 \\
\hline
\end{tabular}

To convert ${ }^{\circ} \mathrm{F}$ to ${ }^{\circ} \mathrm{C}, t^{\circ} \mathrm{C}=\left(t_{\circ} \mathrm{F}-32\right) / 1.8$.

Table 6.3 in PNL-9809 provides monthly average psychometric data for 1950 through 1993. Monthly averages for each year were not available in the document. Therefore, the record monthly dew points listed in the table were assumed to be conservatively representative of a high 
humidity year. A humidity ratio (pounds moisture per pound of dry air) was calculated using the record dew points for use in the model (Table D-2).

Table D-2. Monthly Average Humidity for Heat Removal Analysis.

\begin{tabular}{|l|c|c|}
\hline \multirow{1}{*}{ Month } & Record Dewpoint & Humidity Ratio \\
\hline January & 34.4 & 0.0042 \\
\hline February & 36.7 & 0.0045 \\
\hline March & 37.2 & 0.0046 \\
\hline April & 37.1 & 0.0046 \\
\hline May & 43.8 & 0.0060 \\
\hline June & 47.5 & 0.0069 \\
\hline July & 50.1 & 0.0077 \\
\hline August & 48.4 & 0.0072 \\
\hline September & 45.4 & 0.0064 \\
\hline October & 43.5 & 0.0059 \\
\hline November & 38.3 & 0.0049 \\
\hline December & 34.3 & 0.0041 \\
\hline
\end{tabular}

\section{REFERENCES}

PNL-9809, 1994, Climatological Data Summary, 1993, with Historical Data, Pacific Northwest Laboratory, Richland, Washington. 